\title{
Aquatic Invertebrate Species of Concern on USFS Northern Region Lands
}

Prepared for:

USDA Forest Service

Northern Region

\section{By:}

David M. Stagliano, George M. Stephens and William R. Bosworth

\author{
Montana Natural Heritage Program \\ Natural Resource Information System \\ Montana State Library \\ and \\ Idaho Conservation Data Center \\ Idaho Department of Fish and Game
}

May 2007
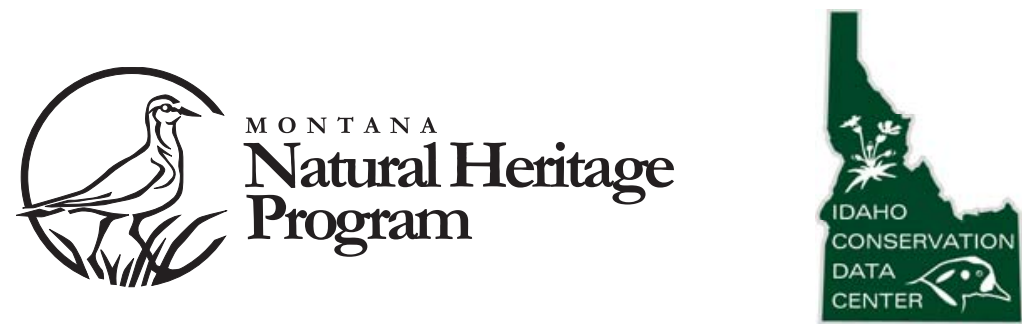



\title{
Aquatic Invertebrate Species of Concern on USFS Northern Region Lands
}

Prepared for:

\author{
USDA Forest Service, Northern Region \\ P.O.Box 7669 \\ Missoula, MT 59807
}

Agreement Number:

\#05-CS-11015600-036

By:

David M. Stagliano ${ }^{1}$, George M. Stephens ${ }^{2}$ and William R. Bosworth ${ }^{2}$

${ }^{1}$ Montana Natural Heritage Program

P.O. Box 201800 • 1515 East Sixth Avenue • Helena, MT 59620-1800

${ }^{2}$ Idaho Conservation Data Center

Idaho Department of Fish and Game

600 S. Walnut St. • Boise, ID 83712

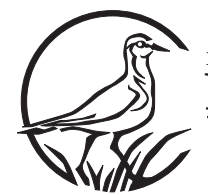

Natural Heritage

Program
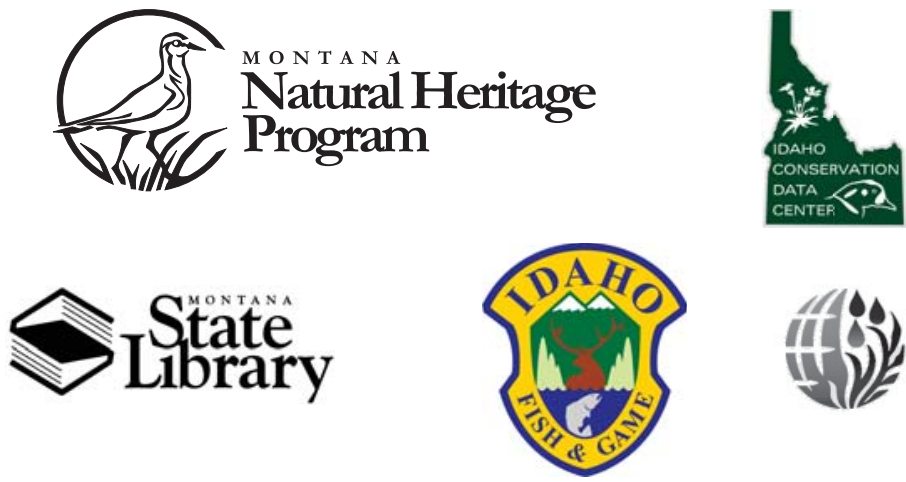

(c) 2007 Montana Natural Heritage Program

P.O. Box 201800 • 1515 East Sixth Avenue • Helena, MT 59620-1800 • 406-444-5354 
This document should be cited as follows:

Stagliano, David, M., George M. Stephens and William R. Bosworth. 2007. Aquatic Invertebrate Species of Concern on USFS Northern Region Lands. Report to USDA Forest Service, Northern Region. Montana Natural Heritage Program, Helena, Montana and Idaho Conservation Data Center, Boise, Idaho. 95 pp. plus appendices. 


\section{Executive Summary}

Using prior published reports, the MT Natural Heritage Program Species of Concern list, the Idaho Comprehensive Wildlife Conservation Strategy (CWCS) and the NatureServe Explorer database as starting points, we compiled a list of 33 aquatic macroinvertebrate species likely to occur within the U.S. Forest Service Northern Region that were ranked as G1-G3 or T1-T3 in 2006, thereby meeting USFS Species of Concern (SOC) criteria, and one mussel taxon ranked Tier I in the MT CFWSCS, thereby meeting USFS Species of Interest (SOI) criteria. Subsequent to evaluating habitat and occurrence data, many of these aquatic invertebrate taxa proved to be peripheral to USFS Northern Region lands and thus, would be of little value to future management plans. Therefore, we pared the initial SOC list down to 19 species and increased the SOI list to 27 species by adding 12 SOI from the Idaho CWCS and another 15 previously considered by MTNHP.

The number of documented aquatic invertebrate SOC species distributed on the Region 1 Forests were as follows: in MT, Beaverhead-Deerlodge (4), Bitterroot (5), Custer (0), Flathead (6), Gallatin (1), Helena (1), Kootenai (1), Lewis \& Clark (2), Lolo (12) and in ID, Clearwater (9), Idaho Panhandle (1), Nez Perce (5), while the number of documented aquatic invertebrate SOI species is as follows: in MT, Beaverhead-Deerlodge (4), Bitterroot (4), Custer (0), Flathead (7), Gallatin (1), Helena (0), Kootenai (0), Lewis \& Clark (1), Lolo (7) and in ID, Clearwater (9), Idaho Panhandle (1), Nez Perce (3) (Table 6). The patterns of aquatic SOC and SOI diversity are similar with more of these species occurring in the Lolo, Clearwater and Flathead National Forests.

We documented 218 new locations for nine SOC taxa and the SOI freshwater mussel during our 2006 study. This study also documented four SOC species that are newly reported or at least re-discovered for Montana, the Lolo mayfly, Caurinella idahoensis (5 sites), the stonefly, Soliperla salish (4 sites) and the caddisflies,
Rossiana montana (7 sites) and Goereilla baumanni (3 sites) all within the Lolo National Forest. A positive outcome of this study will be downgraded global ranks for at least two species (the Agapetus caddisfly, Agapetus montanus and the mayfly, Caudatella edmundsi) from G1G3 to G3. Unfortunately, this study reports the presumed extirpation of the shortface lanx, Fisherola nuttali in the state of MT due to no sightings in the past 50 years, and other extirpations of known sites reported from the literature. Furthermore, the taxonomic validity of 3 SOC Stagnicola spp. (elrodi, elrodiana and montanensis) is in debate by different taxonomists, and has lead to enough ambiguity of their species status that they are no longer tracked by MTNHP or comprehensively surveyed, but their existing site locations are reported.

Initial findings indicate that the number of USFS aquatic SOC increases with proximity to the IdahoMontana border, especially within the Clearwater \& Lolo National Forests which lie in the Northern Rocky Mountain Refugium (NRMR) area. The NRMR area is an important trans-border area of species endemism starting from Lookout Pass in the north to Lost Trail Pass in the south, which is an island of mountainous forest spared from the glaciers and Lake Missoula flooding to the north and lava flows from the south. In terms of habitats, the highest diversity of USFS SOC species are found in the steep-gradient headwater, forested streams (12 species), with the next most "important" SOC habitat being moderate gradient, medium-sized, forested streams (10 species), followed by the cold mountain spring and seep habitats (6). Additional inventory in these habitats within the NRMR area would be worthwhile to fill remaining distribution gaps, to evaluate habitat associations thoroughly enough to develop predictive distribution models, and build the foundation for developing a long-term SOC monitoring and a robust aquatic management protection plan. 


\section{ACKNOWLeDgements}

We especially wish to thank Ann Carlson (USFS) who recognized the need to address aquatic invertebrates in the forest planning process, appreciating the limited information available for management decision making, and promoting the project through an existing USFS Agreement with the MTNHP and IDCDC. Thanks need to go to present \& previous Heritage Program zoologists who chose to collect and address special-interest invertebrates, which are often over-shadowed by the "charismatic" fauna. We wish to thank all the field crews out there on the PIBO project and MT \& ID DEQ monitoring efforts who are out there every year collecting valuable data, and the taxonomists identifying thousands of invertebrates in an effort to characterize stream habitat or water quality, and in turn sometimes documenting these rare species. Dr. Bob Wisseman (Aquatic Biological Associates) examined some of our caddisflies. Bryce Maxell was extremely helpful in the mapping process and for reviewing this report. Scott Blum (MTNHP) was vital in entering and ensuring quality data in the POD database from which the maps were produced. Jonathan Hogg (IDCDC) assisted with the development of Idaho database records, and Coburn Currier (MTNHP) edited, formatted and printed this report; greatly improving the final product. We thank them all. 


\section{Table of Contents}

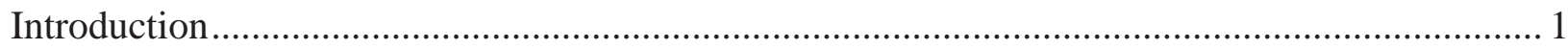

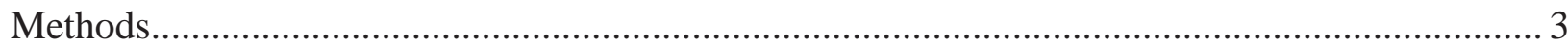

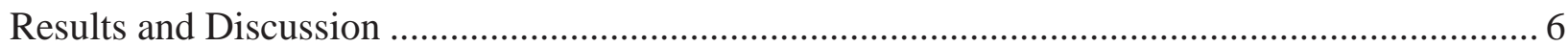

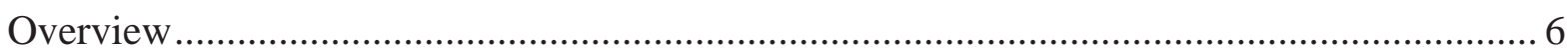

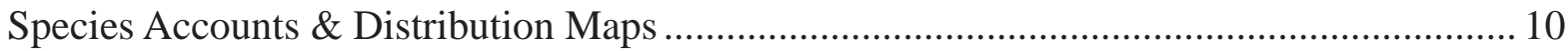

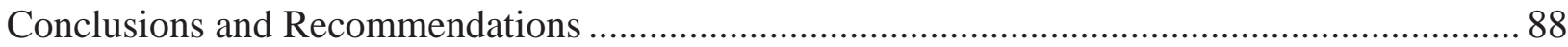

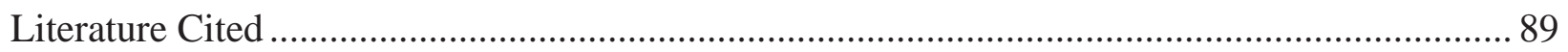

Appendix A. Global/State Rank Definitions

Appendix B. Aquatic Survey Sites with SOC added to the USFS Region 1 in 2006

Appendix C. Selected Aquatic SOI and Potential SOC Species Accounts

\section{LiST OF Figures}

Figure 1. Forest boundaries of the USFS Region1 f................................................ 1

Figure 2. Typical "mountain spring” habitat supporting aquatic SOC in the NRMR .............. 2

Figure 3. Typical steep forested stream habitat supporting aquatic SOC in the NRMR .......... 2

\section{List OF TABLES}

Table 1. Initial Aquatic Invertebrate Species of Concern distribution by Forest in Region 1..... 4

Table 2. Aquatic Invertebrate Species of Concern habitat associations ................................... 5

Table 3. MTNHP 2006 Survey sites where Species of Concern were detected ........................ 6

Table 4. Idaho DEQ cold-water stenotherm macroinvertebrate taxa........................................ 7

Table 5. Final List of Aquatic Invertebrate SOC for consideration by USFS Region 1............ 8

Table 6. Final List of Aquatic Invertebrate SOI for consideration by USFS Region 1 .............. 9 



\section{INTRODUCTION}

The United States Forest Service (USFS) is required under the National Forest Management Act (1976) and Code of Federal Regulations (CFR 1985) to maintain the diversity of plant and animal species. Aquatic ecosystem protections within the USFS Northern Region managed lands are included in Forest Plan strategies and plan components. These include: desired conditions for water quality and riparian conservation areas (RCA's), in-stream habitat protection, and the protection of species-of-concern (SOC) and species-of-interest (SOI) (USFS 2006). Comprehensive information and management plans exist for most aquatic vertebrate species of conservation concern (e.g. Bull and Westslope Cutthroat Trout), but the same information is lacking to non-existent for the aquatic invertebrate SOC. Identifying site locations and the habitat requirements of these aquatic invertebrate species is critical to their proper management and protection, because they may inhabit specialized niches not included in the protection plans of the vertebrates. Data compilation and inventory is an initial step to evaluating the conservation needs of these SOC species and identifying landscapes within national forests with a high likelihood of supporting these populations. Pursuant to this, the Northern Region initiated this mapping and inventory study in 2006 to compile and map records of aquatic invertebrates (SOC) ranked G1-G3 within or near National Forest Service lands of Montana and Idaho. Within the broad landscape area bounded by the USFS Northern Region ( 25 million acres) is an endemic hot-spot important to the Northern Rocky Mountains which we will hereafter call the Northern Rocky Mountain Refugium Area (NRMR) (Johnston \& Steele 1978, Gustafson 2001, Stark and Gustafson 2004) (Figure 1).

Part of this area in Idaho is called the Clearwater Refugium (Brunsfeld et al. 2001). In simplest terms, it is the mountainous, forested area along the Montana and Idaho border that was neither covered by northern ice sheets during glaciation periods, nor paved with lava from the south and west. Higher elevations within the area allowed existing populations to survive there and to be safe from the fluctuating water levels of Glacial Lake Missoula. This is a large diverse area from Lookout Pass in the north, southward to Lost Trail Pass, and it contains parts of three separate ecoregions; the Northern and Middle Rockies and

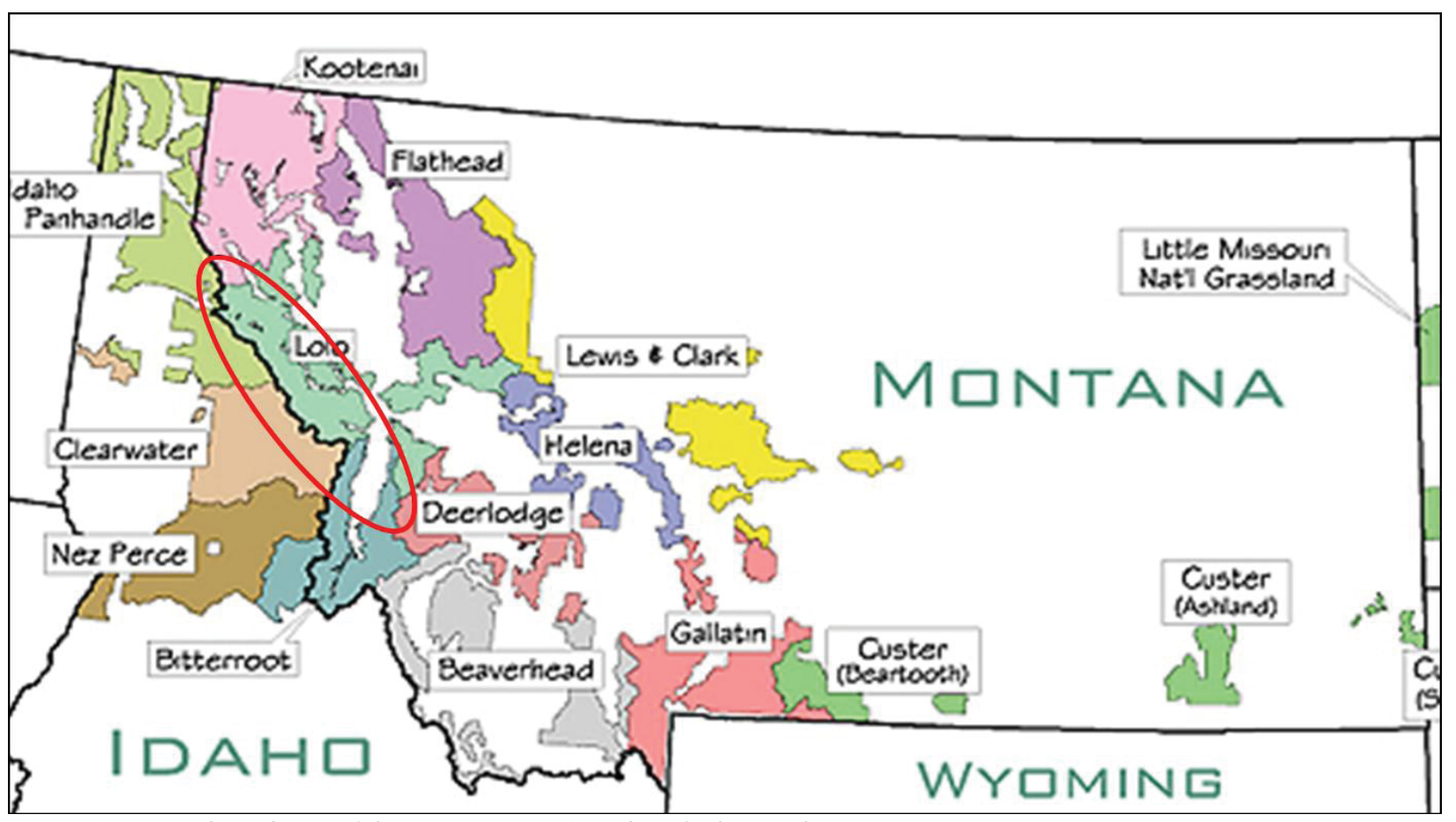

Figure 1. Forest boundaries of the USFS Region 1. Red circle depicts the NRMR 
the Idaho Batholith (Woods et al. 2002). This area of the Montana and Idaho border region not only contains endemic genera and species, but also several additional species restricted to the Pacific Northwest (western WA,OR), with disjunct populations in northern Idaho and northwestern Montana (Frest and Johannes 1995, Stark and Gustafson 2004, Hendricks 2003). Despite more recent survey efforts, many areas in central and northern Idaho, as well as western Montana have rarely, if ever been inventoried, especially for invertebrates. This can be demonstrated by the recent discovery of a new slug genus in northern Idaho (Leonard et al. 2003), the new discoveries of the Idaho Giant Salamander in MT (Maxell, unpublished data), and two new aquatic invertebrate species (Fend and Gustafson 2001, Gustafson 2001) with one new stonefly species (Soliperla salish) being the first report of this genus in the Interior Rocky Mountains (Stark and Gustafson 2004). One of the most frequently mentioned aquatic habitats harboring these species is the high elevation, steep gradient, denselyforested headwater stream (Stark and Gustafson 2004) (Figure 2 and 3 ).

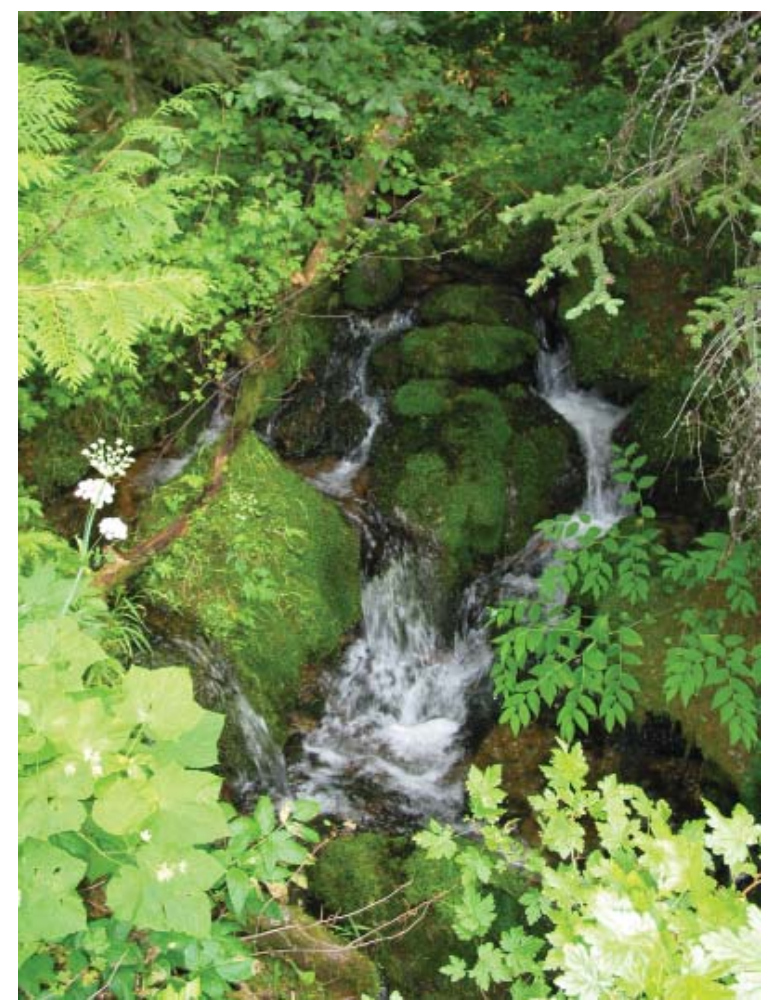

Figure 2. Typical "mountain spring” habitat supporting aquatic SOC in the NRMR

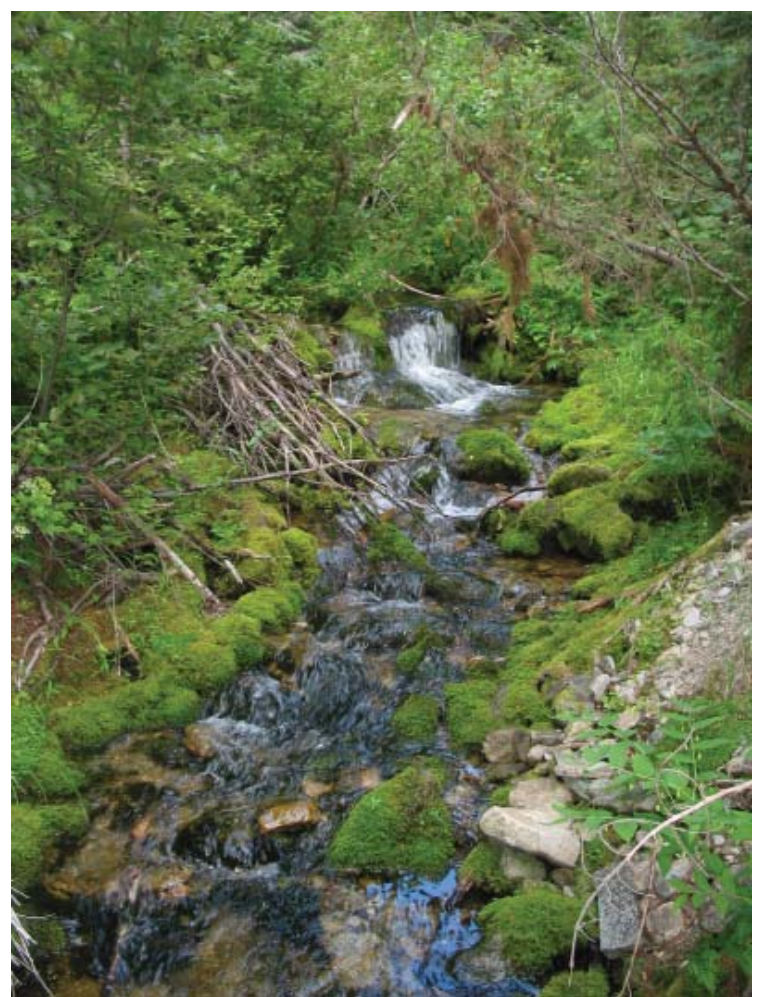

Figure 3. Typical steep forested stream habitat supporting aquatic SOC in the NRMR

Many of these $1^{\text {st }}$ order headwaters (source streams) are fishless due to downstream natural (i.e. waterfalls or other hydrologic constraints) or man-made (culverts) barriers (Stagliano, personal observation). Only recently have biologists become increasingly concerned with aquatic species and habitats other than those directly related to sport-fish (i.e. trout); thus, this has prompted renewed inventories and evaluation of management practices that could have potentially detrimental affects on these lesser-known species. Therefore, objectives of this study are: 1) to obtain a better understanding of the ecological requirements and distributional status of $\sim 30$ aquatic invertebrate species of conservation concern within the USFS Northern Region Lands; 2) to fill species distribution gaps and update old or non-existent records with new site visits to refine known locations; and 3) to identify habitats and ecological requirements of these species within watersheds that have the highest potential to contain these sensitive aquatic species and provide enough information to enable us to predictively model stream reaches for distribution or for future targeted surveys. 


\section{Methods}

Prior to conducting field surveys, we initially utilized a USFS species-of-concern list compiled by Region 1 (Kurt Nelson and Ann Carlson, pers. comm.). Literature searches of published and gray literature, as well as museum records and aquatic invertebrate databases (maintained by NatureServe, MTNHP, IDCDC, BLM Buglab, MT \& IDDEQ) allowed us to complete the list of high-priority "target" species (globally \& state rare species in Montana, and globally rare species in Idaho) likely or known to occur in USFS managed lands. This resulted in a list of 33 species that we considered to be of conservation concern (Table 1). For Montana, early findings during this study revealed that six of the G1-G3 species listed are highly unlikely to occur on USFS Northern Region lands and would thus, be of little value to future management plans. Four of these species (Rhyacophila ebria, R. glaciera, Zapada glacier and Lednia tumana) are restricted to Glacier National Park (Glacier and Flathead Counties) which is managed by the National Park Service, and two warm-springs beetles (Microcylloepus browni \& Zaitzevia thermae) which occur at one site owned by the US Fish and Wildlife Service. For Idaho, three species on the SOC list (Cicindela columbica, Ameletus tolae, Paraleptophlebia traverae) will no longer be considered for similar reasons. Therefore, we did not focus time or resources to perform additional surveys or compilation of information for those species. These SOC lists are meant to be dynamic with species additions or removals' occurring as new information becomes available.

We then generated a list of general habitat associations for these high-priority species (Table 2), to help us prioritize habitats for survey. Limited ecological information and the addition of "new taxa" made this process more problematic for the high-priority species occurring in the MT / ID border region.

We conducted field surveys for macroinvertebrates from late-June to early August 2006 within the targeted sampling period recommended by MTDEQ (2005). Macroinvertebrates were collected from all habitats within the sampling reach of the stream with a 500 micron D-frame dipnet using randomized stream transect methods described in Barbour et al. (1999) and EMAP/BLM protocols (Lazorchak et al. 1998). All dipnet jabs or kicks were combined into one sample where all the organisms and organic materials in the net were washed on a 500 micron sieve, transferred to a 1 liter Nalgene bottle, labeled and preserved in $95 \%$ ethanol and brought back to the MTNHP lab in Helena for processing. Lab processing and invertebrate identification followed EMAP/BLM protocols to maintain consistency with previously collected samples (Lazorchak et al. 1998). We recorded GPS coordinates and a variety of habitat and local site information at each survey location, as well as taking site photos (Appendix B). Survey data have been entered into the Montana Natural Heritage Program Point Observation Database (POD); copies of the Idaho macroinvertebrate data were sent to the Idaho Conservation Data Center (CDC) in Boise. We collected voucher specimens of all Species of Concern (SOC) that we discovered, as well as retained representatives of all other non-SOC taxa preserved in 95\% ethanol. We sent caddisfly specimens from Idaho and western Montana to taxonomic experts, and their identifications have been verified. 
Table 1. Initial Aquatic Invertebrate Species of Concern distribution by Forest in Region 1

\begin{tabular}{|c|c|c|c|c|c|c|c|c|c|c|c|c|c|c|}
\hline \multirow[b]{2}{*}{ Common Name } & \multirow[b]{2}{*}{ Scientific name } & \multirow[b]{2}{*}{ G-Rank } & \multicolumn{9}{|c|}{ Montana Forest $^{a}$} & \multicolumn{3}{|c|}{ Idaho Forest $^{\text {b }}$} \\
\hline & & & B-D & BI & $\mathbf{C U}$ & FL & GA & HE & KO & L-C & LO & $\mathbf{C L}$ & I-P & $\mathbf{N}-\mathbf{P}$ \\
\hline \multicolumn{15}{|l|}{ Freshwater Beetles } \\
\hline Columbia River tiger beetle & Cicindela columbica & G2 & & & & & & & & & & & & $\mathbf{X}$ \\
\hline Brown's Microcylloepus riffle & Microcylloepus browni & G1 & & & & & हn & & & & & & & \\
\hline Warm Spring Zaitzevian riffle & Zaitzevia thermae & G1 & & & & & 3 & & & & & & & \\
\hline \multicolumn{15}{|l|}{ Sponge } \\
\hline A Freshwater Sponge & Ephydatia cooperensis & G1G3 & & & & $?$ & & & & & $\mathbf{x}$ & & & \\
\hline \multicolumn{15}{|l|}{ Caddisflies } \\
\hline An Agapetus Caddisfly & Agapetus montanus & G2 & $\mathbf{X}$ & $\mathrm{X}$ & $?$ & $\underline{X}$ & $\underline{x}$ & $\underline{x}$ & $\underline{X}$ & $\underline{X}$ & $\underline{X}$ & ? & $?$ & $?$ \\
\hline Alexander's Rhyacophilan & Rhyacophila alexanderi & G2 & & $\mathrm{X}$ & & $?$ & & & & $?$ & $\mathrm{X}$ & & & \\
\hline A Rhyacophilan Caddisfly & Rhyacophila ebria & G2G3 & & & & से & & & & & & & & \\
\hline A Rhyacophilan Caddisfly & Rhyacophila glacieri & G3 & & & & है & & & & & & & & \\
\hline A Rhyacophilan Caddisfly & Rhyacophila newelli & G3 & $?$ & & & $?$ & & & & $?$ & $\mathrm{X}$ & & & \\
\hline NRMR Caddisfly* & Sericostriata surdickae & G1G3 & $\mathbf{X}$ & $\mathrm{X}$ & & & & & & & $\mathbf{X}$ & $\underline{X}$ & & $\mathbf{X}$ \\
\hline NRMR Caddisfly* & Rossiana montana & G2G3 & & & & & & & & & $\mathbf{X}$ & $?$ & & \\
\hline NRMR Caddisfly* & Goereilla baumanni & G2G3 & & & & $?$ & & & & & $\mathbf{X}$ & $?$ & & \\
\hline \multicolumn{15}{|l|}{ Stoneflies } \\
\hline Meltwater Lednian Stonefly & Lednia tumana & G1 & & & & 3 & & & & & & & & \\
\hline A Stonefly & Pictetiella expansa & G3 & & ? & & $\mathbf{X}$ & & & ? & ? & ? & $\mathbf{X}$ & $\mathbf{X}$ & $\mathbf{X}$ \\
\hline A Stonefly & Soyedina potteri & G3 & & & & $\mathrm{X}$ & & & & & $\mathrm{X}$ & $\mathrm{X}$ & & \\
\hline Clearwater Roachfly (New)* & Soliperla salish & G? & & & & & & & & & $\mathbf{X}$ & $\mathbf{X}$ & & \\
\hline A Stonefly & Taenionema umatilla & G3 & & & & & & & & & & $\mathbf{X}$ & & \\
\hline A Stonefly & Zapada cordillera & G3 & & & & $\mathbf{x}$ & & & & $\underline{x}$ & $\mathbf{x}$ & $\underline{X}$ & & \\
\hline Western Glacier Stonefly & Zapada glacier & G2 & & & & हो & & & & & & & & \\
\hline \multicolumn{15}{|l|}{ Mayflies } \\
\hline A Mayfly & Ameletus sparsatus & G3G4 & & & & & $\mathrm{X}$ & & & & & & & \\
\hline A Mayfly & Ameletus suffusus & G2G4 & & & & & & & & & & $\mathrm{X}$ & & $\mathrm{X}$ \\
\hline A Mayfly & Ameletus tolae & G1G3 & & & & & & & & & & $\mathbf{x}$ & $?$ & \\
\hline Lolo Mayfly* & Caurinella idahoensis & G1G3 & & & & & & & & & $\bar{X}$ & $\underline{X}$ & & \\
\hline A Mayfly* & Caudatella edmundsi & G1G3 & $\mathbf{x}$ & $\mathrm{x}$ & & & & & & & $\mathbf{x}$ & $\mathbf{x}$ & & \\
\hline A Mayfly & Darameletus columbiae & G2 & & & & & & & & & & $\mathrm{X}$ & & \\
\hline A.Mayfly & Paraleptophlebia traverae & GH & & & & & & & & & & & & $\underline{x}$ \\
\hline \multicolumn{15}{|l|}{ Freshwater Snails } \\
\hline Pristine Pyrg & Pristinicola hemphilli & G3 & & & & & & & & & & & & $\mathrm{X}$ \\
\hline Shortface Lanx & Fisherola nuttalli & G2 & & & & & & & \& & & & & & $\mathbf{X}$ \\
\hline Shortspire Pondsnail & Stagnicola idahoensis & G1 & & & & & & & & & & & & $\mathbf{X}$ \\
\hline Flathead Pondsnail & Stagnicola elrodi & G1 & & & & $\mathbf{X}$ & & & & $\underline{x}$ & & & & \\
\hline Longmouth Pondsnail & Stagnicola elrodiana & G1 & $\mathbf{X}$ & & & $\mathbf{X}$ & & & & & & & & \\
\hline Mountain Marshsnail & Stagnicola montanensis & G3 & & $\mathrm{X}$ & & $\mathrm{X}$ & & & & & & & & \\
\hline \multicolumn{15}{|l|}{$\begin{array}{l}\text { Northern Region Aquatic } \\
\text { SOI (CFWS T1, PSOC) } \\
\end{array}$} \\
\hline \multicolumn{15}{|l|}{ Freshwater Mussels } \\
\hline Western Pearlshell & Margaritifera falcata & G3G4 & $\mathrm{x}$ & $\mathbf{x}$ & & $\mathrm{x}$ & $?$ & & $x$ & $\mathrm{x}$ & $\mathrm{x}$ & $\mathbf{x}$ & $\mathrm{x}$ & $\mathbf{x}$ \\
\hline \multicolumn{2}{|l|}{ Total SOC \& SOI } & & 5 & 6 & 0 & 8 & 2 & 1 & 2 & 4 & 13 & 12 & 2 & 9 \\
\hline $\begin{array}{l}\text { a MT Forests codes: Beaverheac } \\
\text { Clark (L-C), Lolo (LO). } \\
\text { b Idaho Forest codes: Clearwate } \\
\text { * new species for Montana SOC } \\
\text { ? = Potential to occur in this for } \\
\text { = Data does not supnort the }\end{array}$ & $\begin{array}{l}\text { id-Deerlodge (B-D), Bitterroot ( } \\
\text { er (CL), Idaho Panhandle (I-P), } \\
\text { C list } \\
\text { rest., but not verified or recorde }\end{array}$ & $\begin{array}{l}\text { Custer (CL } \\
\text { Perce (N-P }\end{array}$ & $\begin{array}{l}\text { U), Flat } \\
\text { P). }\end{array}$ & nead ( & L), Ga & llatin & (GA), & Helen & $\mathrm{a}(\mathrm{HE})$ & ), Koo & tenai ( & KO), L & Lewis \& & \\
\hline
\end{tabular}


Table 2. Aquatic Invertebrate Species of Concern habitat associations

\begin{tabular}{|c|c|c|c|c|c|c|c|c|c|c|c|}
\hline \multirow[b]{2}{*}{ Scientific Name } & \multirow[b]{2}{*}{ G-Rank } & \multicolumn{4}{|c|}{ Small Lotic Systems } & \multicolumn{2}{|c|}{ Medium Rivers } & \multicolumn{2}{|c|}{ Large Rivers } & \multicolumn{2}{|c|}{ Lentic Systems } \\
\hline & & $\begin{array}{l}\text { Warm } \\
\text { Springs }\end{array}$ & \begin{tabular}{|c} 
Cold \\
Mtn \\
Springs
\end{tabular} & $\begin{array}{c}\text { Steep } \\
\text { Forested } \\
\text { Streams }\end{array}$ & $\begin{array}{c}\text { High } \\
\text { Alpine }\end{array}$ & $\begin{array}{c}\text { Moderate } \\
\text { Gradient } \\
\text { Forested }\end{array}$ & $\begin{array}{c}\text { Low } \\
\text { Gradient } \\
\text { Foothills }\end{array}$ & $\begin{array}{l}\text { Sand } \\
\text { Bars }\end{array}$ & $\begin{array}{c}\text { Fast } \\
\text { current, } \\
\text { cobble } \\
\text { substrate }\end{array}$ & $\begin{array}{c}\text { Natural } \\
\text { Lakes }\end{array}$ & $\begin{array}{l}\text { Ponds } \\
\text { Wetland }\end{array}$ \\
\hline \multicolumn{12}{|l|}{ Freshwater Beetles } \\
\hline Cicindela columbica & G2 & & & & & & & $\mathbf{X}$ & & & \\
\hline Microcylloepus browni & G1 & $\mathbf{X}$ & & & & & & & & & \\
\hline Zaitzevia thermae & G1 & $\mathbf{X}$ & & & & & & & & & \\
\hline \multicolumn{12}{|l|}{ Freshwater Sponge } \\
\hline Ephydatia cooperensis & G1G3 & & & & & & & & & $\mathbf{x}$ & \\
\hline \multicolumn{12}{|l|}{ Caddisflies } \\
\hline Agapetus montanus & G2 & & & & & $\mathrm{X}$ & $\mathrm{X}$ & & & & \\
\hline Rhyacophila alexanderi & G2 & & & $\mathbf{X}$ & & $?$ & & & & & \\
\hline Rhyacophila ebria & G2G3 & & & & $\mathbf{X}$ & & & & & & \\
\hline Rhyacophila qlacieri & G3 & & & & $\mathbf{X}$ & & & & & & \\
\hline Rhyacophila newelli & G3 & & & $\mathrm{X}$ & & $?$ & & & & & \\
\hline Sericostriata surdickae & G1G3 & & & $\mathbf{X}$ & & & & & & & \\
\hline Rossiana montana & G2G3 & & $\mathbf{x}$ & $\mathrm{X}$ & & & & & & & \\
\hline Goereilla baumanni & G2G3 & & $\mathrm{X}$ & $\mathrm{X}$ & & & & & & & \\
\hline \multicolumn{12}{|l|}{ Stoneflies } \\
\hline Lednia tumana & G1 & & & & $\mathbf{X}$ & & & & & & \\
\hline Pictetiella expansa & G3 & & & $\mathbf{x}$ & & $\mathbf{X}$ & & & & & \\
\hline Soyedina potteri & G3 & & $\mathbf{X}$ & $\mathbf{x}$ & & $\mathbf{X}$ & & & & & \\
\hline Soliperla salish & G? & & $\mathbf{x}$ & $\mathbf{x}$ & & & & & & & \\
\hline Taenionema umatilla & G3 & & & $\mathbf{X}$ & & $\mathrm{X}$ & & & & & \\
\hline Zapada cordillera & G3 & & & $\mathbf{X}$ & & $\mathbf{X}$ & & & & & \\
\hline Zapada glacier & G2 & & & & $\mathrm{X}$ & & & & & & \\
\hline \multicolumn{12}{|l|}{ Mayflies } \\
\hline Ameletus sparsatus & G3G4 & & & & & $\mathbf{X}$ & & & & & \\
\hline Ameletus suffusus & G2G4 & & & & & $\mathbf{X}$ & & & & & \\
\hline Ameletus tolae & G1G3 & & & & & $\mathbf{X}$ & & & & & \\
\hline Caurinella idahoensis & G1G3 & & & $\mathbf{X}$ & & & & & & & \\
\hline Caudatella edmundsi & G1G3 & & & $\mathbf{x}$ & & $\mathbf{x}$ & & & & & \\
\hline Parameletus columbiae & G2 & & & & & & & & & $\underline{X}$ & $\mathbf{X}$ \\
\hline Paraleptophlebia traverae & GH & & & $?$ & & $?$ & & & & & \\
\hline \multicolumn{12}{|l|}{ Freshwater Snails } \\
\hline Pristinicola hemphilli & G3 & & $\mathrm{X}$ & & & & & & & & \\
\hline Fisherola nuttalli & G2 & & & & & & & & $\mathbf{X}$ & & \\
\hline Stagnicola idahoensis & G1 & & & & & & & & $\mathbf{X}$ & & \\
\hline Stagnicola elrodi & G1 & & & & & & & & & $\mathbf{X}$ & \\
\hline Stagnicola elrodiana & G1 & & & & & & & & & $\mathbf{X}$ & \\
\hline Stagnicola montanensis & G3 & & & & & & & & & & $\mathbf{x}$ \\
\hline \multicolumn{12}{|c|}{$\begin{array}{l}\text { Northern Region Aquatic SOI } \\
\text { (CFWS T1, PSOC) }\end{array}$} \\
\hline \multicolumn{12}{|l|}{ Freshwater Mussels } \\
\hline Margaritifera falcata & G3G4 & & & & & $\mathbf{X}$ & $\mathbf{X}$ & & $\mathbf{x}$ & & \\
\hline Total SOC \& SOI & & 2 & 5 & 12 & 4 & 10 & 2 & 1 & 3 & 4 & 2 \\
\hline
\end{tabular}




\section{Results AND Discussion}

\section{Overview}

We conducted a total of 26 stream site visits in 2006; 20 included macroinvertebrate sampling (19 in the Lolo National Forest), and we performed Margaritifera mussel surveys at 6 sites (Table 3). Macroinvertebrate sampling concentrated in the $1^{\text {st }}$ and $2^{\text {nd }}$ order headwater streams of the NRMR area where the databases showed significant sampling gaps. Of the 26 visited sites 16 contained at least one SOC (Table 3). We also evaluated $\sim 300$ previously collected macroinvertebrate samples (by USFS PIBO or MT \& IDDEQ) for SOC occurrences. These samples were distributed on the Forests as follows: Beaverhead-Deerlodge (60), Bitterroot (15), Custer (10), Flathead (24), Gallatin (20), Helena (30), Kootenai (25), Lewis \& Clark
(19), Lolo (40), Clearwater (25), Idaho Panhandle (30), Nez Perce (18). Evaluating these samples (in addition to MTNHP field visits) allowed us to document 218 new locations for nine SOC taxa and the SOI mussel during this study (Appendix B).

This study also documented four invertebrate SOC that are newly reported or re-discovered for Montana; the Lolo mayfly, Caurinella idahoensis (5 sites), the Clearwater Roachfly, Soliperla salish (4 sites) and the caddisflies, Rossiana montana (7 sites) and Goereilla baumanni (3 sites) all but one collected within the Lolo National Forest. A positive outcome of this study will be downgraded global ranks for at least two species (the caddisfly, Agapetus montanus, and the mayfly, Caudatella

Table 3. MTNHP 2006 survey sites where Species of Concern were detected

\begin{tabular}{|c|c|c|c|c|c|c|}
\hline Stream & Lat & Long & $\begin{array}{c}\text { Land } \\
\text { Ownership }\end{array}$ & County & $\begin{array}{c}\text { collection } \\
\text { date }\end{array}$ & $\begin{array}{c}\# \text { of SOC / } \\
\text { SOI } \\
\text { species }\end{array}$ \\
\hline West Fork Gold Creek & 46.57458 & -113.65662 & USFS Lolo & Missoula & 25-Jun-06 & 0 \\
\hline Stony Creek & 47.10939 & -114.39590 & USFS Lolo & Missoula & 12-Jul-06 & 1 \\
\hline Mormon Creek & 46.71799 & -114.14264 & USFS Lolo & Missoula & 11-Jul-06 & 0 \\
\hline Mormon Creek & 46.70895 & -114.21036 & USFS Lolo & Missoula & 11-Jul-06 & 0 \\
\hline Bitterroot River ${ }^{1}$ & 46.75465 & -114.06207 & FWP FAS & Missoula & 11-Jul-06 & 0 \\
\hline Bitterroot River $^{1}$ & 46.72191 & -114.04672 & FWP FAS & Missoula & 11-Jul-06 & 0 \\
\hline Butler Creek & 47.12561 & -114.43692 & USFS Lolo & Missoula & 12-Jul-06 & 2 \\
\hline Dry Creek & 47.15278 & -114.42696 & USFS Lolo & Missoula & 12-Jul-06 & 0 \\
\hline Kennedy Creek & 47.16473 & -114.42344 & USFS Lolo & Missoula & 12-Jul-06 & 1 \\
\hline trib to McCormick Creek & 47.17323 & -114.42976 & USFS Lolo & Missoula & 12-Jul-06 & 2 \\
\hline McCormick Creek & 47.15250 & -114.48667 & USFS Lolo & Missoula & 12-Jul-06 & 1 \\
\hline West Fork Lolo Creek & 46.68552 & -114.55801 & USFS Lolo & Mineral & 10-Jul-06 & 1 \\
\hline Lolo Creek $^{1}$ & 46.74342 & -114.15599 & USFS Lolo & Missoula & 10-Jul-06 & 0 \\
\hline Lolo Creek $^{1}$ & 46.76618 & -114.34048 & Private & Missoula & 10-Jul-06 & 0 \\
\hline Ninemile Creek ${ }^{1}$ & 47.08190 & -114.43920 & Private & Missoula & 12-Jul-06 & 0 \\
\hline Clearwater R. ups Seeley Lake ${ }^{1}$ & 47.22560 & -113.53650 & USFS Lolo & Missoula & 15-Jul-06 & 1 \\
\hline Clearwater R. ups Seeley Lake ${ }^{1}$ & 47.21850 & -113.53460 & USFS Lolo & Missoula & 15-Jul-06 & 1 \\
\hline Coyle Creek & 47.25786 & -115.27180 & USFS Lolo & Mineral & 02-Aug-06 & 2 \\
\hline Green Creek & 47.31486 & -115.48840 & USFS Lolo & Mineral & 02-Aug-06 & 2 \\
\hline Unnamed Trib to M. Fork Big Cr. & 47.31589 & -115.43355 & USFS Lolo & Mineral & 01-Aug-06 & 2 \\
\hline Unnamed trib to Big Creek & 47.32606 & -115.42636 & USFS Lolo & Mineral & 01-Aug-06 & 3 \\
\hline North Fork Second Creek & 47.16404 & -114.71135 & USFS Lolo & Mineral & 03-Aug-06 & 1 \\
\hline Grizzly Creek & 46.57458 & -113.65662 & USFS Lolo & Missoula & 01-Aug-06 & 1 \\
\hline South Fork Trout Creek & 46.98803 & -114.99716 & USFS Lolo & Mineral & 03-Aug-06 & 3 \\
\hline Van Ness Creek & 47.08209 & -114.93500 & USFS Lolo & Mineral & 02-Aug-06 & 2 \\
\hline Total NHP Sites w/ SOC species & & & & & & 16 \\
\hline
\end{tabular}


edmundsi) from G1G3 to a G3. Unfortunately, this study reports the presumed extirpation of the shortface lanx, Fisherola nuttali in the state of MT due to no sightings in the past 50 years, and other extirpations of known sites reported from the literature. In addition to focusing on SOC, we collected distribution data on 45 non-SOC coldwater stenotherm species, 17 of these species were closely associated with our USFS SOC taxa in the NRMR area (particularly Caudatella edmundsi, Caurinella idahoensis, Rhyacophila alexanderi, Pictetiella expansa, Sericostriata surdickae, Soyedina potteri (Table 4). Identifying sites that contain suitable habitat in conjunction with this suite of associated taxa will further refine our ability to predict stream reaches within watersheds containing these species of conservation concern.

The highest diversity of USFS SOC species are found in the steep-gradient, headwater forested streams (12 species), with the next most "important" SOC habitat being the moderate gradient medium-sized, forested streams (10 species), followed by the cold mountain springs and seep habitats (6 species) (Table 2). However, differentiation between cold mountain springs and steep $1^{\text {st }}$ order headwater streams can be problematic. Oftentimes, mountain spring and seep areas can exist on steep hill-slopes alongside the stream channel itself contributing to flow and

Table 4. Idaho DEQ Designated Cold Water Taxa and Temperature Preferences. Bolded and underlined taxa are close associates with USFS SOC species: Caudatella edmundsi, Caurinella idahoensis, Rhyacophila alexanderi, Pictetiella expansa, Soyedina potteri.

\begin{tabular}{|c|c|c|c|c|c|}
\hline Order & Genus/Species & $\begin{array}{c}\text { Temp. } \\
\text { Preference } \\
\left({ }^{\circ} \mathrm{C}\right)\end{array}$ & Order & Genus/Species & $\begin{array}{c}\text { Temp. } \\
\text { Preference } \\
\left({ }^{\circ} \mathrm{C}\right) \\
\end{array}$ \\
\hline \multirow[t]{3}{*}{ Coleoptera } & Heterlimnius & 11.24 & \multirow[t]{6}{*}{ Diptera } & Glutops & 9.4 \\
\hline & Lara & 11.56 & & Hesperoconopa & 10.76 \\
\hline & Narpus & 12.58 & & Oreogeton & 9.29 \\
\hline \multirow[t]{13}{*}{ Ephemeroptera } & Ameletus similor & $\underline{8.74}$ & & Rhabdomastix & 10.12 \\
\hline & Baetis bicaudatus & $\underline{8.76}$ & & Heleniella & 8.13 \\
\hline & Caudatella hystrix & $\underline{8.25}$ & & Diamesa & 10 \\
\hline & Cinygmula sp. & 10.31 & \multirow[t]{20}{*}{ Trichoptera } & Anagapetus & 8.26 \\
\hline & Drunella coloradensis & 9.86 & & Apatania & 11.04 \\
\hline & Drunella doddsi & 10.47 & & Neophylax & 10.88 \\
\hline & Drunella flavilinea & 9.98 & & Neothremma alicia & Z.65 \\
\hline & Drunella spinifera & 10.56 & & Neothremma & 8.66 \\
\hline & Epeorus deceptivus & $\underline{9.9}$ & & Oligophlebodes sp. & $\mathrm{Z.87}$ \\
\hline & Epeorus grandis & 9.95 & & Parapsyche elsis & $\underline{9.47}$ \\
\hline & Rhithrogena hageni & 8.25 & & Parapsyche sp. & 9.38 \\
\hline & Rhithrogena robusta & 6.84 & & Rhyacophila albertagr. & 6.47 \\
\hline & Cultus sp. & 11.04 & & Rhyacophila betteni gr. & 10.61 \\
\hline \multirow[t]{14}{*}{ Plecoptera } & Despaxia augusta & Z.09 & & Rhyacophila brunnea gr. & 10.56 \\
\hline & Kogotus sp. & $\underline{8.12}$ & & Rhyacophila hyalinata gr. & 10.2 \\
\hline & Leuctridae & 9.43 & & Rhyacophila iranda gr. & 8.02 \\
\hline & Megarcys & 10.15 & & Rhyacophila narvae gr. & 9.53 \\
\hline & Nemouridae & 10.03 & & Rhyacophila sibirica gr. & 7.42 \\
\hline & Paraperla & 9.32 & & Rhyacophila vaccua & 8.02 \\
\hline & Setvena & $\underline{7.99}$ & & Rhyacophila vagrita gr. & 8.63 \\
\hline & Sweltsa & 11.45 & & Rhyacophila valuma & 6.87 \\
\hline & Taeniopterygidae & 6.3 & & Rhyacophila verrula & Z.58 \\
\hline & Visoka cataractae & $\underline{9.52}$ & & Rhyacophila vofixa & 8.57 \\
\hline & Yoraperla brevis & 10.36 & \multirow[t]{4}{*}{ Turbellaria } & Polycelis coronata & $\underline{9.76}$ \\
\hline & Yoraperla & 8.84 & & & \\
\hline & Zapada columbiana & 9.71 & & & \\
\hline & Zapada oregonensis gr. & $\underline{8.8}$ & & & \\
\hline
\end{tabular}


providing habitat for at least a couple of SOC caddisflies (Ross 1956). Therefore, management consideration and protection in the broadest sense for these headwater sources will benefit the most SOC species.

The number of documented aquatic invertebrate SOC species distributed on the Region 1 Forests were as follows: in MT, Beaverhead-Deerlodge (4), Bitterroot (5), Custer (0), Flathead (6), Gallatin (1), Helena (1), Kootenai (1), Lewis \& Clark (2), Lolo (12) and in ID, Clearwater (9), Idaho Panhandle (1), Nez Perce (5) (Table 5).

The number of documented aquatic invertebrate SOI species is as follows: in MT, BeaverheadDeerlodge (4), Bitterroot (4), Custer (0), Flathead (7), Gallatin (1), Helena (0), Kootenai (0), Lewis
\& Clark (1), Lolo (7) and in ID, Clearwater (9), Idaho Panhandle (1), Nez Perce (3) (Table 6). The patterns of SOC and SOI occurrences are similar with more species of conservation concern in the Lolo, Clearwater and Flathead National Forests. The final list of SOC aquatic invertebrate species that should be strongly considered by the USFS Region One in any forest management plan includes 19 species (Table 5), followed by 27 species on the SOI list (Table 6).

Species accounts of the final SOC, and those initially compiled but later removed are presented next. Several species accounts of the SOI are included in Appendix C, while additional SOI species will become available in the next year on the MTNHP Animal Field Guide. These SOC lists are meant to be dynamic with species added

Table 5. Final List of Aquatic Invertebrate SOC for consideration by USFS Region 1.

\begin{tabular}{|c|c|c|c|c|c|c|c|c|c|c|c|c|c|c|}
\hline \multirow[b]{2}{*}{ Common Name } & \multirow[b]{2}{*}{ Scientific name } & \multirow[b]{2}{*}{ G-Rank } & \multicolumn{9}{|c|}{ Montana Forest $^{\mathrm{a}}$} & \multicolumn{3}{|c|}{ Idaho Forest $^{b}$} \\
\hline & & & B-D & BI & $\mathbf{C U}$ & FL & GA & HE & KO & L-C & LO & CL & I-P & N-P \\
\hline \multicolumn{15}{|l|}{ Sponge } \\
\hline A Freshwater Sponge & Ephydatia cooperensis & G1G3 & & & & ? & & & & & $\mathbf{x}$ & & & \\
\hline \multicolumn{15}{|l|}{ Caddisflies } \\
\hline An Agapetus Caddisfly & Agapetus montanus & G3 & $\mathrm{X}$ & $\mathbf{X}$ & $?$ & $\mathbf{X}$ & $\mathbf{X}$ & $\mathbf{x}$ & $\mathrm{X}$ & $\mathbf{X}$ & $\mathrm{X}$ & $?$ & $?$ & $?$ \\
\hline Alexander's Rhyacophilan & Rhyacophila alexanderi & G2 & & $\mathbf{X}$ & & $?$ & & & & $?$ & $\mathrm{X}$ & & & \\
\hline A Rhyacophilan Caddisfly & Rhyacophila newelli & G3 & $?$ & & & $?$ & & & & $?$ & $\mathrm{X}$ & & & \\
\hline NRMR Caddisfly* & Sericostriata surdickae & G1G3 & $\mathbf{x}$ & $\mathbf{x}$ & & & & & & & $\mathbf{X}$ & $\mathbf{X}$ & & $\mathbf{X}$ \\
\hline NRMR Caddisfly* & Rossiana montana & G2G3 & & & & & & & & & $\mathbf{X}$ & $?$ & & \\
\hline NRMR Caddisfly* & Goereilla baumanni & G2G3 & & & & $?$ & & & & & $\mathrm{X}$ & $?$ & & \\
\hline \multicolumn{15}{|l|}{\begin{tabular}{|l} 
Stoneflies \\
\end{tabular}} \\
\hline A Stonefly & Pictetiella expansa & G3 & & $?$ & & $\mathbf{X}$ & & & $?$ & $?$ & $?$ & $\mathbf{X}$ & $\mathbf{X}$ & $\mathbf{X}$ \\
\hline A Stonefly & Soyedina potteri & G3 & & & & $\mathbf{X}$ & & & & & $\mathrm{X}$ & $\mathbf{X}$ & & \\
\hline Clearwater Roachfly (New)* & Soliperla salish & G2 & & & & & & & & & $\mathrm{X}$ & $\mathbf{X}$ & & \\
\hline A Stonefly & Taenionema umatilla & G3 & & & & & & & & & & $\mathbf{X}$ & & \\
\hline A Stonefly & Zapada cordillera & G3 & & & & $\mathbf{X}$ & & & & $\mathbf{X}$ & $\mathrm{X}$ & $\mathbf{X}$ & & \\
\hline \multicolumn{15}{|l|}{ Mayflies } \\
\hline Lolo Mayfly* & Caurinella idahoensis & G1G3 & & & & & & & & & $\mathbf{X}$ & $\mathbf{X}$ & & \\
\hline A Mayfly* & Caudatella edmundsi & G3 & $\mathbf{X}$ & $\mathbf{x}$ & & & & & & & $\mathbf{x}$ & $\mathbf{x}$ & & \\
\hline A Mayfly & Parameletus columbiae & G2 & & & & & & & & & & $\mathbf{X}$ & & \\
\hline \multicolumn{15}{|l|}{ Freshwater Snails } \\
\hline Pristine Pyrg & Pristinicola hemphilli & G3 & & & & & & & & & & & & $\mathbf{X}$ \\
\hline Shortface Lanx & Fisherola nuttalli & G2 & & & & & & & & & & & & $\mathbf{X}$ \\
\hline Longmouth Pondsnail & Stagnicola elrodiana & G1 & $\mathbf{x}$ & & & $\mathbf{X}$ & & & & & & & & \\
\hline Shortspire Pondsnail & Stagnicola idahoensis & G1 & & & & & & & & & & & & $\mathbf{X}$ \\
\hline Mountain Marshsnail & Stagnicola montanensis & G3 & & $\mathbf{X}$ & & $\mathbf{X}$ & & & & & & & & \\
\hline Total SOC & & & 4 & 5 & 0 & 6 & 1 & 1 & 1 & 2 & 12 & 9 & 1 & 5 \\
\hline \multicolumn{15}{|c|}{$\begin{array}{l}\text { a MT Forests codes: Beaverhead-Deerlodge (B-D), Bitterroot (BI), Custer (CU), Flathead (FL), Gallatin (GA), Helena (HE), Kootenai (KO), Lewis \& } \\
\text { Clark (L-C), Lolo (LO). }\end{array}$} \\
\hline
\end{tabular}


Table 6. Final List of Aquatic Invertebrate SOI for consideration by USFS Region 1

\begin{tabular}{|c|c|c|c|c|c|c|c|c|c|c|c|c|c|c|}
\hline \multirow[b]{2}{*}{ Common Name } & \multirow[b]{2}{*}{ Scientific name } & \multirow[b]{2}{*}{ G-Rank } & \multicolumn{9}{|c|}{ Montana Forest ${ }^{a}$} & \multicolumn{3}{|c|}{ Idaho Forest $^{\text {b }}$} \\
\hline & & & B-D & BI & $\mathbf{C U}$ & FL & GA & HE & KO & L-C & LO & CL & I-P & N-P \\
\hline \multicolumn{15}{|l|}{ Freshwater Mussels } \\
\hline Western Pearlshell & Margaritifera falcata & G3G4 & $\mathbf{x}$ & $\mathbf{X}$ & & $\mathbf{X}$ & ? & & $\mathbf{x}$ & $\mathbf{x}$ & $\mathbf{x}$ & $\mathrm{x}$ & $\mathbf{x}$ & $\mathbf{X}$ \\
\hline \multicolumn{15}{|l|}{\begin{tabular}{|l} 
Caddisflies \\
\end{tabular}} \\
\hline An Caddisfly & Allomyia bifosa & G3G4 & & & & ? & & & & & & & ? & \\
\hline An Caddisfly & Apatania comosa & G2G3 & & $\mathbf{X}$ & & & & & & $?$ & $\mathbf{x}$ & $?$ & & $\mathbf{X}$ \\
\hline An Caddisfly & Arctopora salmon & G1G3 & & & & & & & & & & $?$ & $?$ & \\
\hline An Caddisfly & Cryptochia furcata & G3G4 & & & & $?$ & & & & & $\mathbf{x}$ & & ? & \\
\hline A Rhyacophilan Caddisfly & Rhyacophila gemona & G2G3 & & & & $\mathbf{X}$ & & & & & & & $?$ & \\
\hline A Rhyacophilan Caddisfly & Rhyacophila potteri & G2 & $\mathbf{x}$ & $\mathbf{X}$ & & $\mathbf{X}$ & & & & & $\mathbf{x}$ & $\mathrm{X}$ & & \\
\hline A Rhyacophilan Caddisfly & Rhyacophila unimaculata & G2G3 & & & & $\mathbf{X}$ & & & & & & & $?$ & \\
\hline \multicolumn{15}{|l|}{ Stoneflies } \\
\hline A Stonefly & Bolshecapnia sasquatchi & G3 & & & & $\mathbf{X}$ & & & & & $\mathbf{X}$ & & & \\
\hline Straight Stonefly & Capnia lineata & G3 & & & & & & & & & & $\mathrm{X}$ & $?$ & \\
\hline A Stonefly & Capnia zukeli & G2 & & & & & & & & & & $\mathbf{x}$ & $?$ & \\
\hline A Spring Stonefly & Cascadoperla trictura & G3G4 & & & & & & & & & $?$ & $\mathbf{X}$ & $?$ & \\
\hline A Spring Stonefly & Malenka tina & G3 & $?$ & & & & & & & & & & & $?$ \\
\hline A Stonefly & Megaleuctra kincaidi & G2 & & $?$ & & & & & & & $?$ & $\mathbf{X}$ & $?$ & \\
\hline A Stonefly & Megaleuctra stigmata & G2 & & & & ? & & & & & ? & ? & $?$ & \\
\hline A Stonefly & Setvena bradleyi & G3 & $\mathrm{x}$ & $\mathbf{X}$ & & $\mathrm{X}$ & & & & & $\mathrm{x}$ & $\mathbf{x}$ & $\mathbf{x}$ & \\
\hline A Stonefly & Perlomyia collaris & G3 & $?$ & $?$ & & & & & & & $?$ & $?$ & & $?$ \\
\hline \multicolumn{15}{|l|}{ Mayflies } \\
\hline A Mayfly & Ameletus sparsatus & G3G4 & & & & & $\mathbf{x}$ & & & & & & & \\
\hline A Mayfly & Ameletus suffusus & G2G4 & & & & & & & & & & $\mathbf{X}$ & $?$ & $\mathbf{X}$ \\
\hline A Mayfly & Ameletus tolae & G1G3 & & & & & & & & & & & $?$ & \\
\hline A Mayfly & Caudatella jacobi & G3 & $\mathbf{x}$ & ? & & & & & & & $\underline{X}$ & $\underline{X}$ & $?$ & \\
\hline A Mayfly & Paraleptophlebia jenseni & G2G4 & & & & & & & & & & $\underline{X}$ & $?$ & \\
\hline A Mayfly & Paraleptophlebia traverae & GH & & & & & & & & & & & & $\mathrm{X}$ \\
\hline \multicolumn{15}{|l|}{ Freshwater Snails } \\
\hline Large Mantled Physa & Physa megalochlamys & G3 & & & & $\mathrm{X}$ & & & & $?$ & $\mathbf{X}$ & & $?$ & \\
\hline Flathead Pondsnail & Stagnicola elrodi & G1 & & & & $\mathrm{X}$ & & & & $\mathbf{x}$ & & & & \\
\hline Rocky Mountain Capshell & Acroloxus coloradensis & G3 & $?$ & $?$ & & $?$ & & & & & & & & \\
\hline Rocky Mountain Duskysnail & Colligyrus greggi & G4 & $\mathbf{X}$ & $\mathbf{X}$ & $?$ & & & & & & & & & $?$ \\
\hline Total SOI & & & 4 & 4 & 0 & 7 & 1 & 0 & 0 & 1 & 7 & 9 & 1 & 3 \\
\hline \multicolumn{15}{|c|}{$\begin{array}{l}\text { a MT Forests codes: Beaverhead-Deerlodge (B-D), Bitterroot (BI), Custer (CU), } \\
\text { (L-C), Lolo (LO). } \\
\text { b Idaho Forest codes: Clearwater (CL), Idaho Panhandle (I-P), Nez Perce (N-P). } \\
\text { * new species for Montana SOC list }\end{array}$} \\
\hline
\end{tabular}

or removed as new information is obtained or compiled. Multiple species on the SOI list that are ranked G1-G3 have very limited collection and ecological information, so that placing them on the SOC list is premature.
This information, including maps, geo-referenced site photos and distributions for all USFS SOC and SOI species will be made available in the near future on the MTNHP on-line Animal Field Guide and Tracker website. 


\section{Species Accounts \& Distribution Maps}

SPECIES: Cicindela columbica

Heritage Rank: G2, ID: S1

\author{
A. Taxonomy \\ Order: Coleoptera \\ Family: Cicindelidae \\ Cicindela columbica Hatch 1938
}

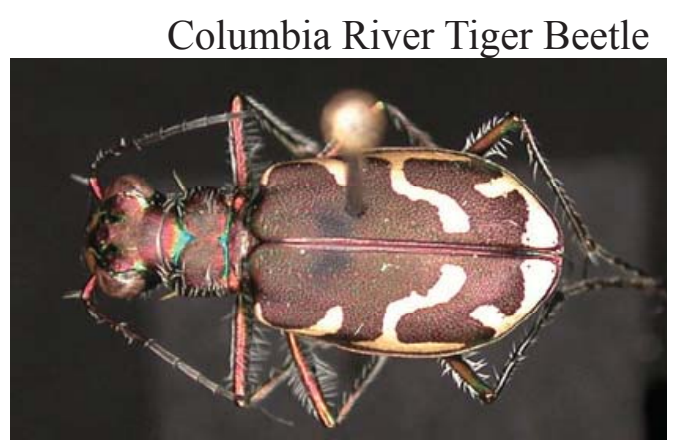

Photo of Cicindela columbica from Idaho taken by Luana McCauley, Idaho Conservation Data Center.

\section{B. Species Description}

Adult Morphology: No detailed information available (see photo).

Reproductive Biology: Based on collections made by Rumpp (1967) and Shook (1981), adult beetles can be found in late July and early August.

Ecology: Cicindela columbica inhabits riparian sand shores along rivers, sharing the river bars and beaches with other tiger beetle species including C. oregona, C. repanda, and C. hirticollis though each finds its own micro-ecological niche in these locations (Rumpp 1967). Shook (1981) found that, on the lower Salmon River, Idaho, C. columbica "generally occupies older, well-established bars that extend back from the river sufficiently to generally not be inundated by spring runoff waters." Shook estimated that the largest populations ranged from 200-400 beetles per sandbar when the sandbars measured approximately $400 \mathrm{~m}$ x $100 \mathrm{~m}$.

\section{Range and Known Sites}

When first described in 1938, Cicindela columbica was reported on sandbars of rivers from The Dalles, Oregon, eastward to just west of Lewiston, Idaho (Shook 1981). After the flooding of portions of the Columbia River by dam backwaters, no evidence of $C$. columbica could be found even though other tiger beetle species which had previously been associated with $C$. columbica (C. oregona, C. repanda, and C. hirticollis) managed to re-establish themselves on the shores of the new reservoirs (Frank Beer, 1971, as reported in Shook 1981).

Cicindela columbica was first found in Idaho in 1962 (Rumpp 1967) along the lower Salmon River. In 1977, Gary Shook (1981) confirmed the presence of the beetle at two locations along the lower Salmon River, and during a 1979 rafting trip from near Riggins, Idaho, to near Rogersburg, Washington, Shook confirmed the presence of the beetle at multiple locations. However, the only populations of C. columbica found by Shook in 1979 were along the lower Salmon River between Rice Creek bridge and the mouth of Eagle Creek, a distance of approximately 26 miles. No C. columbica were found on the lower Salmon River below Eagle Creek and none were found along the Idaho-Oregon Snake River corridor or the IdahoWashington Snake River corridor. 


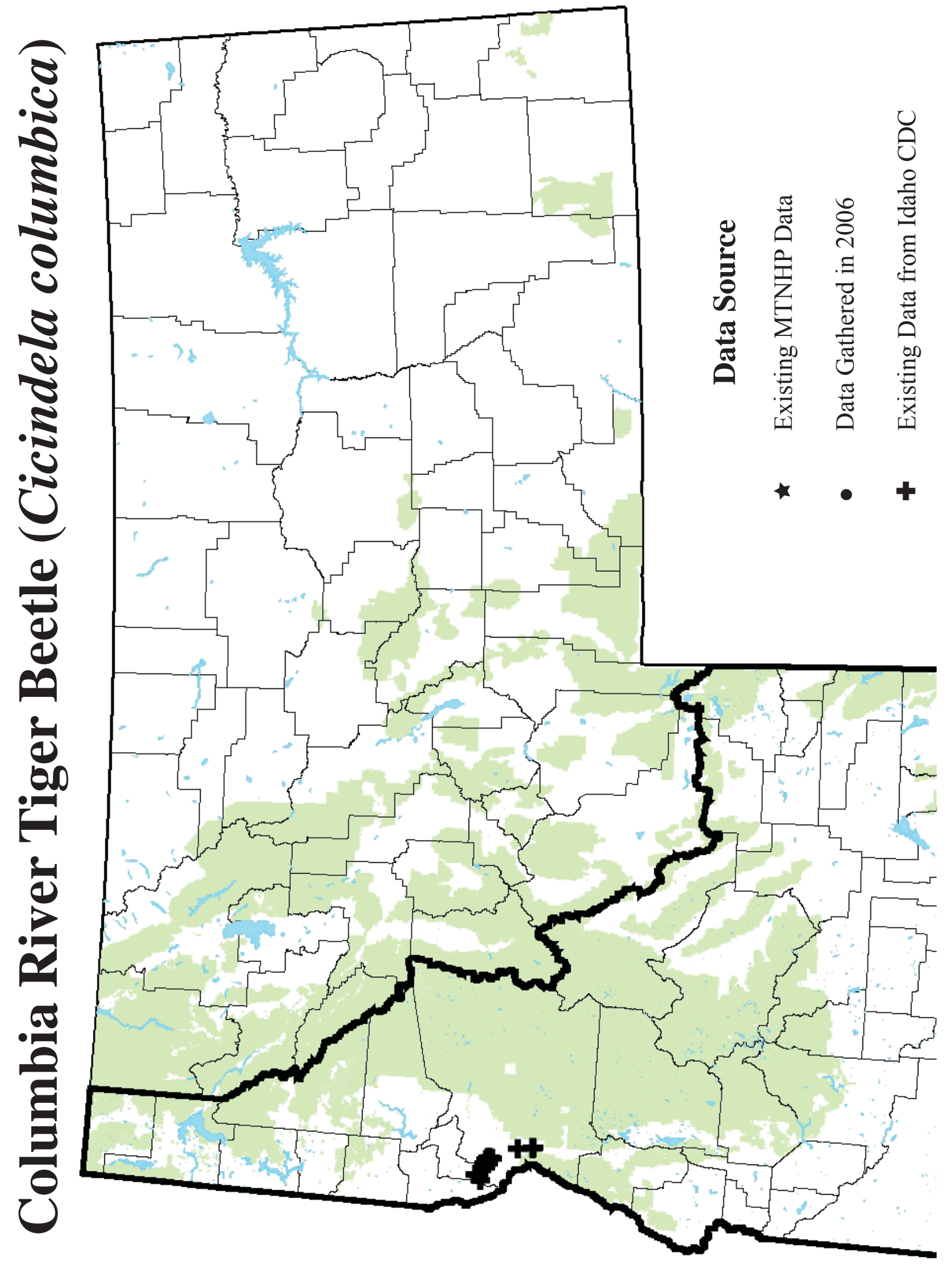




\section{Species Abundance}

Shook (1981) reported that C. columbica is "generally found in large, viable populations within the Lower Salmon River canyon from near Slate Creek to Eagle Creek (Shook 1981).

\section{Current Status}

\section{A. Why Species is of Conservation Concern}

Cicindela columbica has no USFWS status at the present time. No status survey of the lower Salmon River populations has been conducted since Shook (1981). On December 3, 1979, the U. S. Fish and Wildlife Service was petitioned by Gary Shook to list C. columbica as Threatened

or Endangered. The primary threat was a proposed dam on the lower Salmon River. By the time the Fish and Wildlife Service (1988) wrote its finding, the dam was no longer proposed, and the Service found the petition to be unwarranted, basing their decision on lack of threat.

\section{B. Threats}

In 1986, Shook (personal communication to Craig Groves, Idaho Natural Heritage Program) indicated that Columbia River tiger beetle specimens were selling for \$50 each and that the beetles were under threat by collectors. LaBonte (1995) mentions the threat of collecting, driven by the popularity of tiger beetles and the demand for rare and infrequently available species. The lower Salmon River is used extensively for recreation. The impact of recreation on tiger beetle populations is unknown.

\section{Distribution Relative to Land Allocations}

Populations along the lower Salmon River are all associated with state-owned waterways, state lands (Wildlife Management Area), and lands managed by the Bureau of Land Management. This species has no known distribution on USFS Northern Region managed lands, and it is highly unlikely that populations would be found on any USFS National Forests in Idaho. Cicindela columbica should probably be removed from the USFS Species of Conservation Concern List. 
SPECIES: Zaitzevia thermae

Microcylloepus browni

Heritage Rank: G1, MT: S1

\section{Natural History}

\section{A. Taxonomy}

Order: Coleoptera

Family: Elmide

Zaitzevia thermae (Hatch 1938)

Microcylloepus browni (Hatch 1938)

The riffle beetle, Zaitzevia thermae was originally described as Macronychus thermae a small, flightless aquatic beetle found only in Gallatin County, Montana. While Microcylloepus browni was originally described as Heterelmis browni (Hatch 1938).

\section{B. Species Description}

Reproductive Biology: Little is known of the reproduction habits of these beetles, but sexual reproduction of the adults likely occurs on cobbles during winter low water flow periods, and the females will lay eggs on these cobbles or adjacent vegetation.

Ecology: These beetles feed on small pieces of algae and diatoms that they scrape from submerged rocks on the gravel bottom and among vegetation. Both Z. thermae and M. browni require warm and flowing surface water with temperatures of 60 to $84^{\circ} \mathrm{F}$. They are endemic to Bridger Creek Warm Springs near Bozeman, MT.

\section{Range and Known Sites}

Rangewide, the Brown's riffle beetle inhabits and is endemic to four warm water seeps that surface and flow into Bridger Creek along Fish Hatchery Road near Bozeman, MT (Gallatin County). The habitat, which is approximately 35 square meters, is owned by the federal government and lies on the Fish Technology Center property. It is assumed that M. browni is endemic to warm water seeps $250-400 \mathrm{~m}$ downstream from where $Z$. thermae is found (Hooten 1991). Z. thermae has the same known site, except they are further limited to the upstream section of the warm spring.

\section{Species Abundance}

These abundances for each of these species at the springs have been reported to fluctuate between as few as 1 and up to1000 individuals (Hooten 1991, USFWS 2002). Currently, the population is monitored monthly each year through visual confirmation of the presence or absence of beetles under rocks in the warm springs. Thus, each species is vulnerable to extinction with one catastrophic event. 


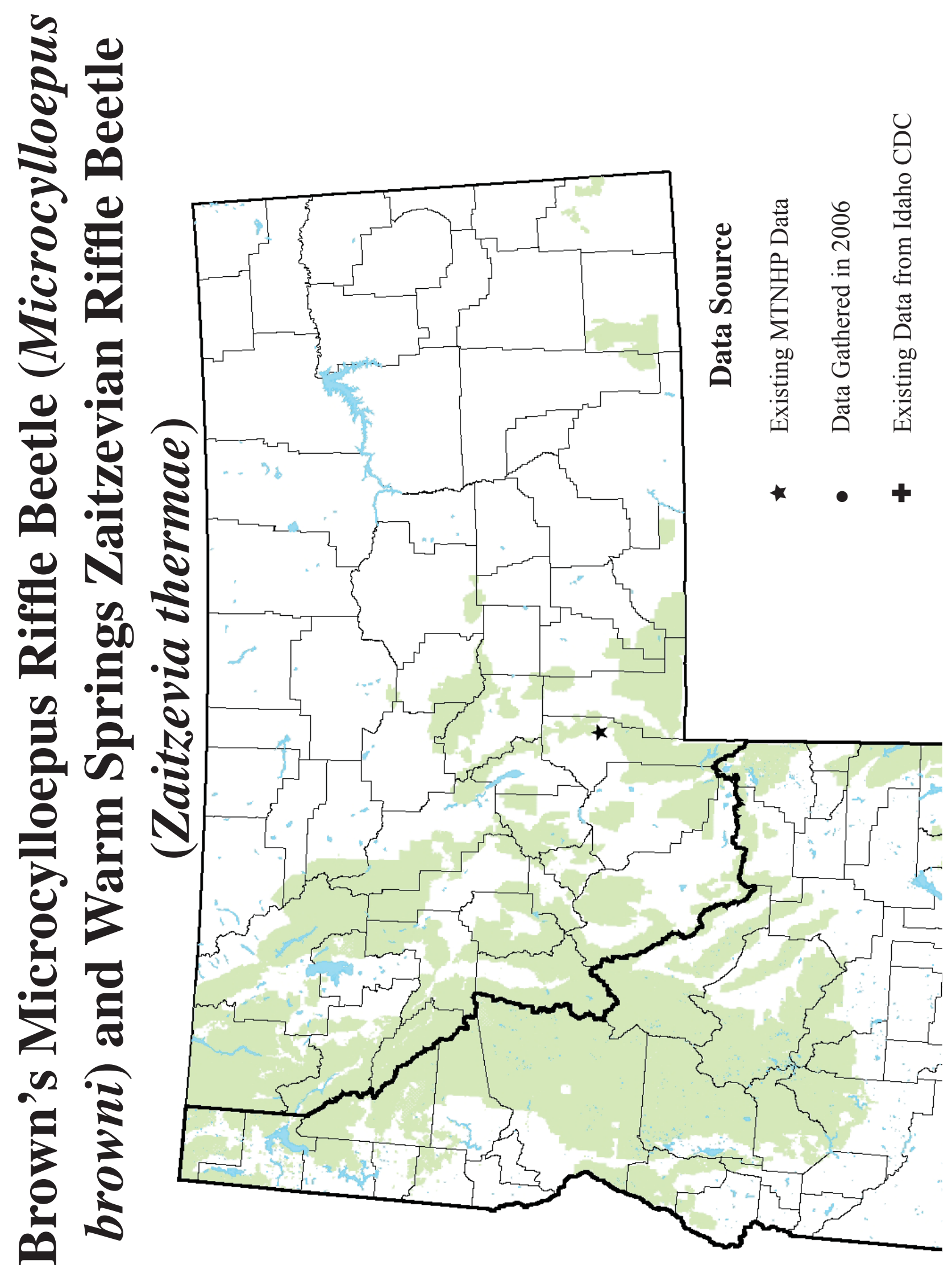




\section{Current Status}

\section{A. Why Species is of Conservation Concern}

Zaitzevia thermae is a candidate for listing under the USFWS Endangered Species Act (USFWS 2006) because of its vulnerability to extinction, and Microcylloepus browni is a MT SOC because they are extremely locally distributed riffle beetles (1 known spring site). They occupy limited spring or seepage habitat (total area $=35 \mathrm{~m}^{2}$ ) in and along Bridger Creek where it flows through the property of the U.S. Fish and Wildlife Service's Bozeman Fish Technology Center (Technology Center) at the mouth of Bridger Canyon, Montana. The globally rare (G1) rankings are largely due to the single locality that this species is found.

\section{B. Threats}

Specific threats to populations of $Z$. thermae and $M$. browni include habitat alteration from the development of warm water and surface water from Bridger Creek which may have adversely affected habitat; although specific impacts are not documented since water use began more than 100 years ago. Upstream land use activities have potential to become a threat but are not known to be a problem at this time aside from some detectable sedimentation.

\section{Distribution Relative to Land Allocations}

These species have no known distribution on USFS Northern Region managed lands, and it is highly unlikely that populations would be found on any USFS National Forests in Montana or Idaho. Populations occur 100\% within Federal ownership, under jurisdiction of U.S. Fish and Wildlife Service. They should probably be removed from the USFS Species of Conservation Concern List. 


\section{Natural History}

\section{A. Taxonomy}

Phylum: Porifera

Family: Spongillidae

Ephydatia cooperensis Addis \& Peterson 2005

This species was previously described as Clypeatula cooperensis Peterson \& Addis 2000, but reassigned into the new genus, Ephydatia. The family Spongillidae and the genus Ephydatia are paraphyletic with respect to the other freshwater sponge family Lubomirskiidae; Ephydatia is also paraphyletic to C. cooperensis. Thus, C. cooperensis was transferred to the genus Ephydatia and the family Lubomirskiidae was subsumed into the Spongillidae (Addis \& Peterson 2005). Type specimens were collected at the outlet of Coopers Lake, where the lake joins Salmon Creek.

\section{B. Species Description}

E. cooperensis is a light tan color and grows as a hard, disc-shaped encrustation on the undersides of rocks and logs (see photo). It lacks microscleres and has amphioxeal megascleres that often show a slight midregion bulb and are usually covered with short, conical spines except at their tips (see Barton \& Addis 1997; Peterson and Addis 2000). The sponge is also non-gemmulating, overwintering in a regressed state in which choanocyte chambers are reduced in number (Peterson and Addis 2000).

Reproductive Biology: Gonochoristic or successively hermaphroditic, with oogenesis and spermatogenesis occurring in separate sponges once per year. Sperm, eggs and embryos present in specimens collected 30 June 1998 (Peterson and Addis 2000).

Ecology: Although sponges are multi-cellular invertebrates, they are sometimes mistaken for aquatic plants or algae. Most freshwater sponges are delicate in structure, growing as encrusting or branching masses. They sometimes appear greenish because of the algae that live on them, although living beneath cobbles or other substrate will limit algae growth and remain lighter colored (see photo). Ephydatia cooperensis occurs on the undersides rocks and logs in cool western Montana natural lakes at depths ranging from 37-80 cm (Peterson and Addis 2000).

\section{Range and Known Sites}

Rangewide, Ephydatia cooperensis is currently known from three lakes in the northern Rocky Mountains of Montana (Peterson \& Addis 2000, NatureServe 2006). These lakes are within the Clearwater and Blackfoot River systems in Missoula and Powell Counties. Range extensions 


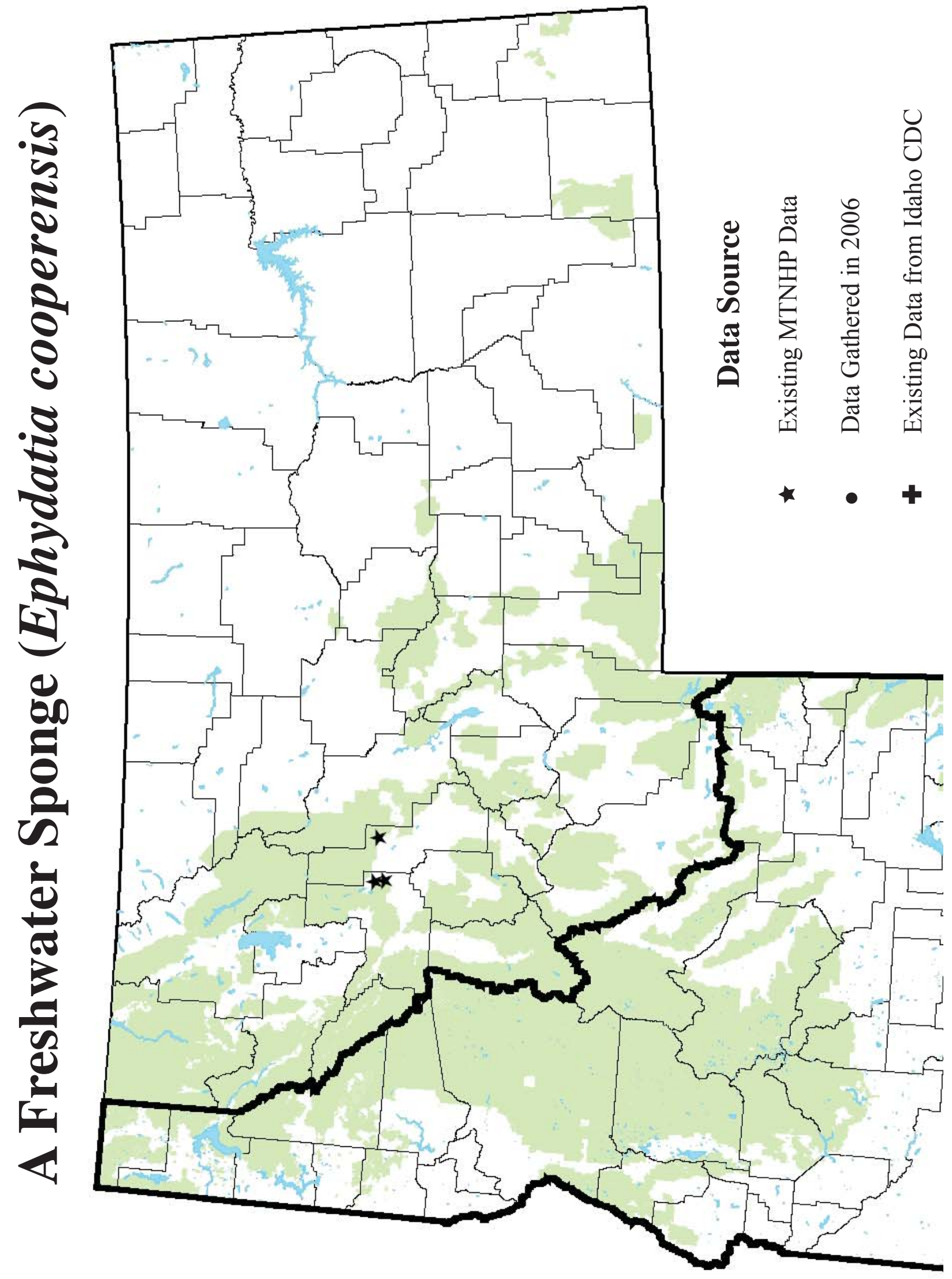


further into the Seeley/Clearwater Natural Lake chain and over into the Swan River Natural Lakes areas are highly probable (Addis, pers. comm. 2007).

\section{Species Abundance}

The occurrence of this species in 3 lakes out of 24 sampled (6 sub-basins) indicates that it appears restricted to the Upper Clark Fork Basin within Montana and is rather uncommon. Additional observation sites are needed within the Salmon /Seeley / Clearwater Natural Lake chain to help determine population size and environmental specificity.

\section{Current Status}

\section{A. Why Species is of Conservation Concern}

Ephydatia cooperensis is only known from 3 natural lakes in one basin of Montana. It has no USFWS status at the present time, although it is currently a US Forest Service Species of Concern (SOC) G1G3 and listed S1S3 in Montana. These rankings were largely due to the lack of localities reported for this species. With additional targeted survey work in the Seeley/Swan Natural Lakes area, we feel confident that more occurrences will be discovered and the rank of this species may be downgraded to at least a G3 and an S3 for the state of Montana.

\section{B. Threats}

Specific threats to populations of Ephydatia cooperensis have not been identified. Although, excessive recreational pressures (i.e. heavy boat traffic, wading, unauthorized boat docking, etc.) may directly affect the sponge's ability to propagate, and live in its shallow water habitats. Water quality degradation and alteration of lentic, littoral aquatic habitat by lakefront building or docks, may be a long-term concern for these populations.

\section{Distribution Relative to Land Allocations}

Current Northern Region distribution of this freshwater sponge involves one lake on the Lolo National Forest, while the other two occurrences are on state-lands (Clearwater Wildlife Management Area) adjacent to the Lolo National Forest. This species is unlikely to occur in another forest unit, unless it is discovered on the southern portion of the Flathead National Forest. 


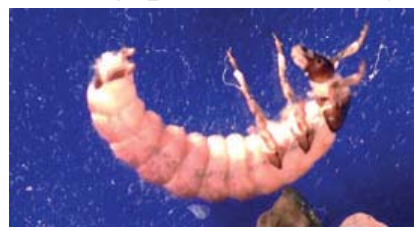

\section{A. Taxonomy \\ Order: Trichoptera \\ Family: Glossosomatidae \\ Agapetus montanus Denning 1949}

The larvae of Agapetus montanus were described from an associated series of adults and mature pupae collected from Drummond, Montana (Denning, 1949), and later Alice Creek and Blackfoot River (Lewis and Clark Co.), as well as Clearwater River (Missoula Co.); but subsequently found in Manitoba and Idaho (Beaver Creek, Clarke Co.; Newell and Minshall, 1977). There are 30 species of Agapetus in North America with the greatest diversity in the Southeast and Pacific Northwest.

\section{B. Species Description}

Adult Morphology: Adult characteristics are covered in Denning (1949). They are commonly known as the Little Black Caddisflies

Larval Morphology: Body length: up to 6mm. Larvae of Agapetus could be confused with Protoptila (another Glossosomatidae), but are readily distinguished by the presence of 2 mesonotal sclerites instead of 3. There have been few larval-adult associations of the Agapetus spp. (7 of 30), so in areas with multiple species, adults or mature pupae are needed for species level identification. The saddle-type rock cases for larval Agapetus usually have larger rocks along the edge of the case (see photo).

Reproductive Biology: Adults of this species emerge from mid-June to mid-August (Wiggins 1996).

Ecology: The larvae of $A$. montanus occur on the upper surfaces and sides of cobbles and boulders in moderate gradient, fast flowing, foothills to mountain streams (Wiggins 1996). This genus inhabits streams with more intermediate characteristics between the higher elevation, cold mountain streams (more likely to find Glossosoma \& Anagapetus), and the large warmer transitional rivers downstream (more likely to find Prototila) (Wiggins 1996). Generally the riparian canopy of the occupied streams is mostly $(>50 \%)$ open, and less shaded than mountain streams. In clear streams and rivers during low flows, it is typical to be able to locate \& identify Agapetus larvae on the tops of rocks. In relation to trophic status, A. montanus larvae scrape, graze and digest algae and diatoms from the surfaces of rocks (Merritt and Cummins 1996). 


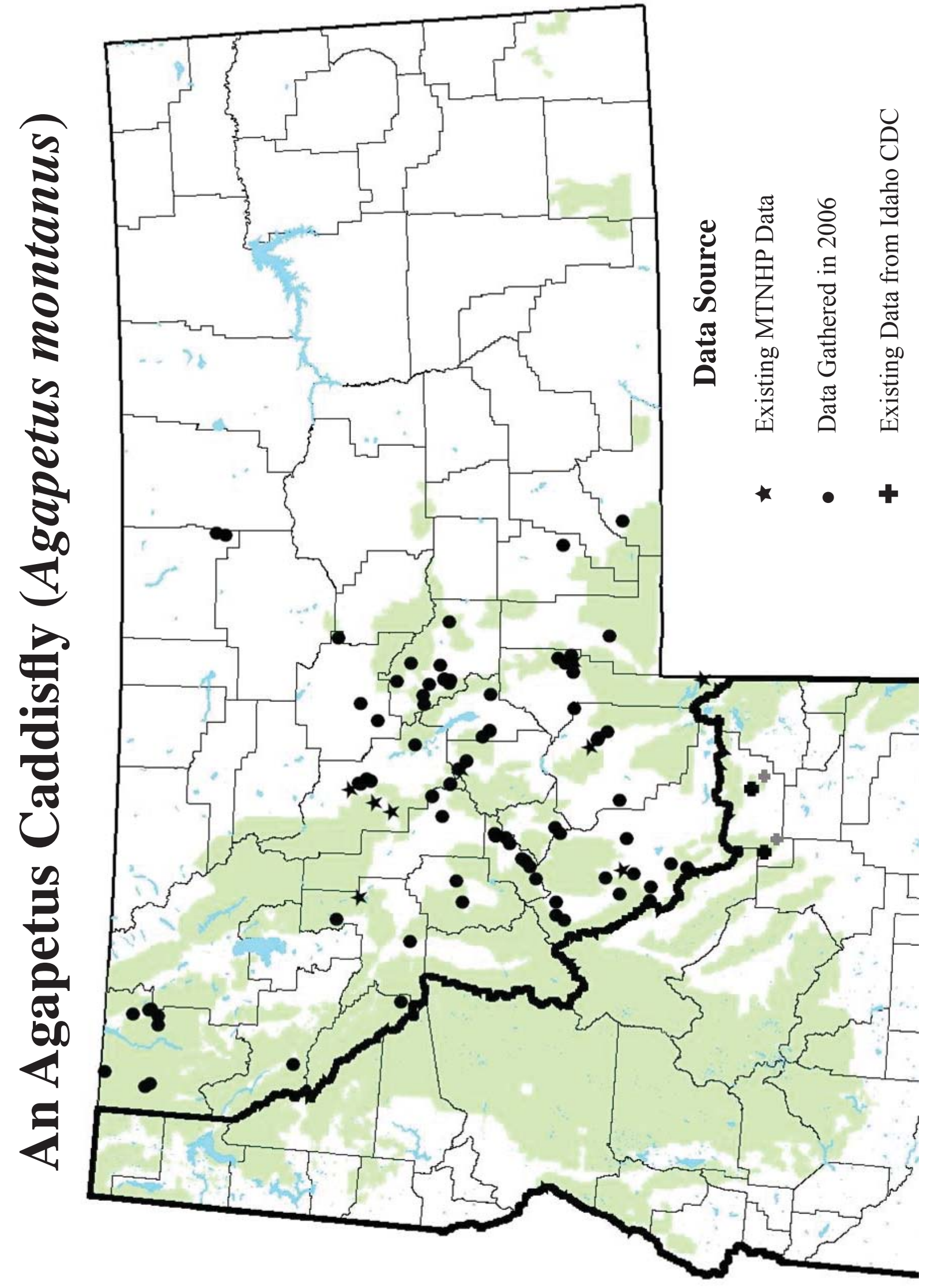




\section{Range and Known Sites}

Rangewide, Agapetus montanus occurs in Idaho, Montana, and Manitoba (Wiggins 1996, Clemson 2006, NatureServe 2006).

In Montana, A. montanus is our only known species based on collections (Gustafson 2006, pers. comm. 2006, NatureServe 2006), thus any genus level identification to Agapetus should be our species of concern, A. montanus. Since this is the case, $A$. montanus has been reported from $\sim 30$ streams in Missoula, Mineral, Gallatin, Granite, Powell, Meagher, Flathead, Deer Lodge, Lewis and Clark, Lincoln, Beaverhead and Sanders Counties.

In Idaho, A. montanus was collected from 2 locations at a small mountain stream near $1800 \mathrm{~m}$ elevation (Newell and Minshall 1979b). This represents the only documented Idaho distribution (Newell and Minshall 1977). Although due to a lack of larval species identifications and multiple Agapetus species reported for ID, there are probably far more streams containing this caddisfly species than have been reported.

\section{Species Abundance}

This compilation study found that $A$. montanus can be rare in a sample (from 1 or 2 individuals in a 500 count) to quite common (up to $33 \%$ or 100 out of 300 individuals) at the sites where they occur. They are more widely distributed than previously thought for Montana.

\section{Current Status}

\section{A. Why Species is of Conservation Concern}

Agapetus montanus has no USFWS status at the present time, nor is one warranted. It is currently a US Forest Service Species of Concern (SOC); listed as endangered in Idaho (S1) and vulnerable to extirpation (S2) in Montana, but these rankings were largely based on a paucity of locations that this species has been previously reported. With this new compilation work and additional targeted survey work, we feel confident that the rank of this species will be downgraded to at least a G3 and an S3 for the state of Montana due to the number of additional streams and river miles the species now appears to occupy.

\section{B. Threats}

Specific threats to Montana \& Idaho populations of A. montanus have not been identified. In general, aquatic invertebrates that feed by grazing and scraping are intolerant of silt and sedimentation which tends to embed cobbles that contain their food source. Thus, improper management practices in the riparian zone (i.e. intensive livestock use) that would increase fine sediment in the streambed substrate and otherwise degrade aquatic habitat is the primary concern these populations.

\section{Distribution Relative to Land Allocations}

Distribution of this species in the Northern Region 1 managed forest lands accounts for about half of the known occurrences. Occurrences in MT include at least one site in almost every forest: Beaverhead-Deerlodge (4), Bitterroot (0), Custer (0, but close to the border), Flathead 
(1), Gallatin (2), Helena (6), Kootenai (8), Lewis \& Clark (4), Lolo (2) with the habitat potential to exist in all forests. The other half of the observations in MT occur on BLM managed lands or streams accessed on private lands. Since this species tends to prefer streams with open canopy, clean cobbles and moderate flow, this habitat type usually occurs where National Forest lands transition to the foothills and valleys. In ID, the two known records occur in Targhee National Forest, but the potential for this species to occur in similar habitats in the Clearwater, Nez Perce and Salmon Forests is highly likely. 
SPECIES: Rhyacophila alexanderi

Heritage Rank: G2, MT: S2

Natural History

\section{A. Taxonomy}

Order: Trichoptera

Family: Rhyacophilidae

Rhyacophila alexanderi Denning 1950
Alexander's Rhyacophilan Caddisfly

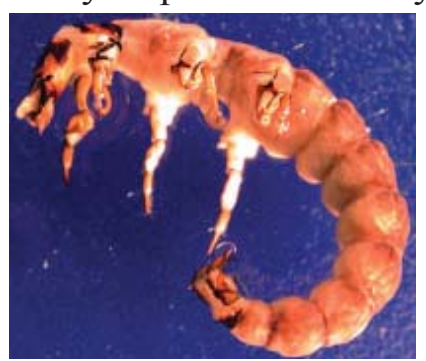

Photo of Rhyacophila alexanderi was unavailable. Photo shows a generalized Rhyacophila larva.

Type Locality: “Bitterroot Forest”, Montana.

The species, Rhyacophila alexanderi was identified from a series of adults collected in Montana (Denning 1950) and no larval association has been made. Because R. alexanderi is a member of the R. alexanderi species grp for which only one species is known from MT (Gustafson 2007), sites with larvae in the group should, in fact, be this rare species, but we could not be sure without mature pupae or adults to verify it

\section{B. Species Description}

Adult Morphology: See Denning 1950 for detailed adult description.

Larval morphology: Mature larval length: 10-11 mm. Head widest medially, as long as wide. Frontoclypeus with dark shading posteriorly, separate muscle scars distinct; maxillary palpus stout. Mandibles with a single apical tooth and abdominal segments are without gills like other members of this species group (Giersch 2002).

Reproductive Biology: In Montana, adults were collected from mid-July-August.

Ecology: There is very little ecological information available on this species. According to Anderson (1976) species of this genus typically inhabit clear, cool creeks, and the known locations in MT fit this general description, including being steep gradient and forested. These caddisfly larvae are free-living and that move actively searching for food (predatory) with no case, until just before pupation. The trophic relationship of Rhyachophila is usually predatory on other insects, especially chironomids (midge larvae) and simulids (blackfly larvae) (Merritt and Cummins 1996).

\section{Range and Known Sites}

Rangewide, this species is known only from the type locality in the Bitterroot Forest (Ravalli County) and at two sites in Lake County, Montana (Yellow Bay creek) (Newell and Potter, 1973), as well as Manitoba (see Denning 1950). 


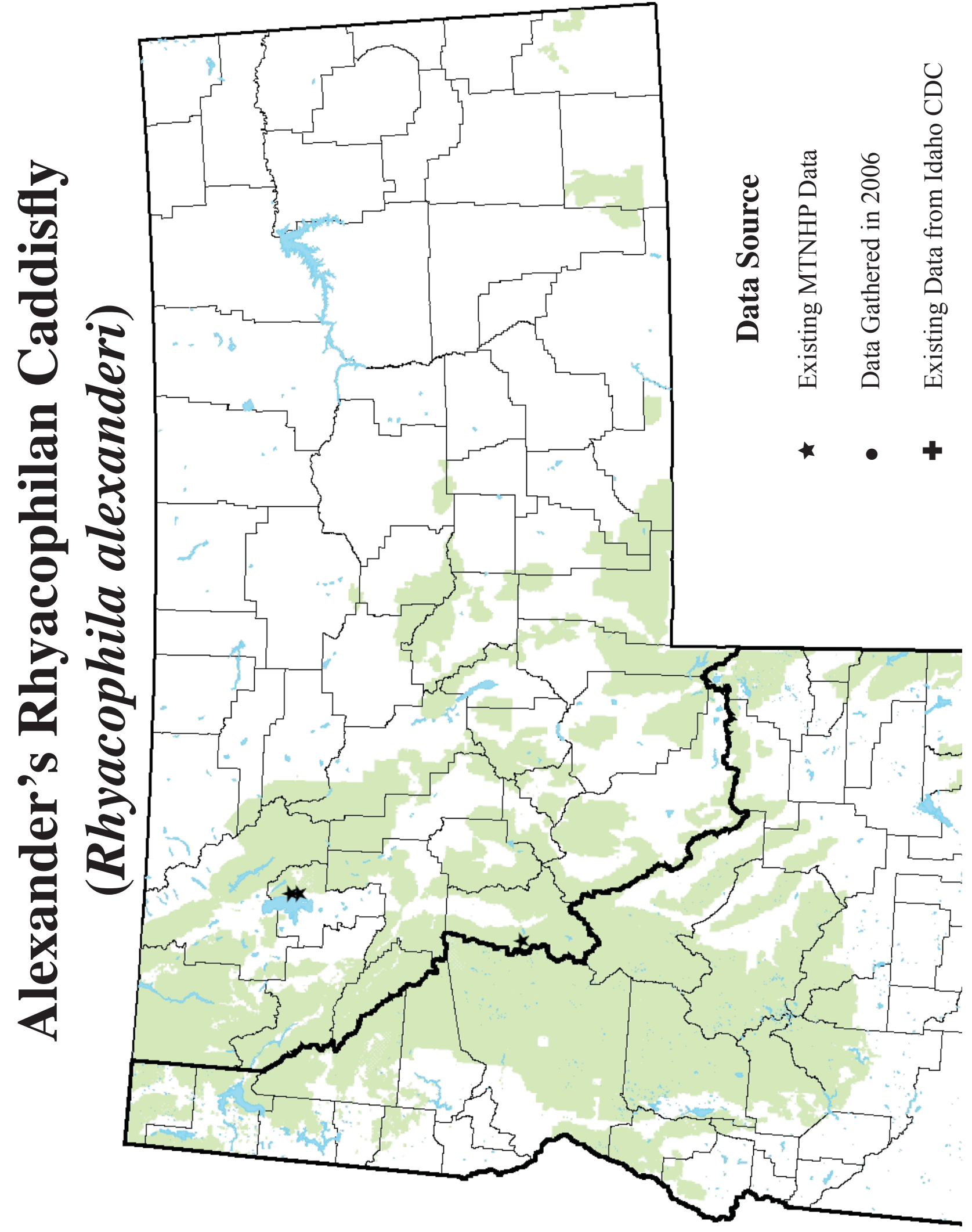




\section{Species Abundance}

These species of Rhyacophila can be abundant in the proper habitat, but are usually fairly rare and very local in abundance.

\section{Current Status}

\section{A. Why Species is of Conservation Concern}

$R$. alexanderi has been described as a rare species due to few reported collections, habitat specificity and it is never abundant when collected (Wiggins 1996). It has no USFWS status at the present time, although it is currently a US Forest Service Species of Concern (SOC); ranked globally rare/uncommon (G2) by Natureserve (2006), and ranked S2 in Montana

\section{B. Threats}

Specific threats to Montana populations of $R$. alexanderi would include mismanagement of forested riparian areas, including sediment and temperature increases associated with road building and timber harvests not following BMPs. In general, cold-stenothermic (coldwater specialists) invertebrate populations can be affected by slight changes to the thermal characteristics of their aquatic habitats, such as alteration of flow patterns, increased sunlight exposure, streambed substrate and water quality. Alteration and degradation of riparian and aquatic habitat is the primary concern for these populations.

\section{Distribution Relative to Land Allocations}

In Montana, $R$. alexanderi currently is known from three sites (one the type locality) in the Bitterroot \& Flathead Forests and this species is likely to occur on other USFS Northern Region managed lands higher up in the watersheds. 
SPECIES: Rhyacophila ebria

Heritage Rank: G2G3, MT: S1

\section{Natural History}

\section{A. Taxonomy}

Order: Trichoptera

Family: Rhyacophilidae

Rhyacophila ebria Denning 1949

The species, Rhyacophila ebria were identified from a series of adults collected in Montana (Denning 1949) and the larval association has just recently been made (Geirsch 2002). Because Rhyacophila ebria is a member of the $R$. rotunda species group for which a larval key is unavailable, reports of site occurrences with the $R$. rotunda grp. (4 in the databases) could potentially contain this rare species, but we could not be sure without mature pupae or adults to verify it. Gustafson (2007) reports that $R$. ebria is the only species of the rotunda species group occurring within Montana.

\section{B. Species Description}

Adult Morphology: See Denning 1949 for detailed adult description.

Larval Morphology: Mature larval length: 10-11 mm. Head widest medially, as long as wide. Frontoclypeus with dark shading posteriorly, separate muscle scars distinct; maxillary palpus stout. Mandibles with a single apical tooth and abdominal segments are without gills like other members of this species group (Giersch 2002).

Reproductive Biology: In Montana, adults have been collected from mid-August through early October.

Ecology: R. ebria is restricted to the northern Rocky Mountains, where it lives in cold alpine streams fed by permanent snowmelt, glaciers or icefields. Nimmo (1971) reported this species from small, turbulent creeks to tiny alpine trickles. Along with $R$. glaciera Denning, this species occurs in the highest, coldest streams in Glacier National Park. Joe Giersch (personal observation) has collected $R$. glaciera pupating and emerging simultaneously with $R$. alberta. These caddisfly larvae are free-living forms that move actively searching for food (predatory) with no case, until just before pupation. The trophic relationships of larvae of Rhyachophila are predatory on other insects, especially chironomid midges and simulidae (blackfly larvae) (Merritt and Cummins 1996).

\section{Range and Known Sites}

Originally described from Glacier Park, Logan Pass, Montana (Denning, 1949; Newell and Potter 1973), but subsequently found in Manitoba and British Columbia (Mt. Revelstoke National Park) (Nimmo and Scudder 1978; Scudder 1994). 


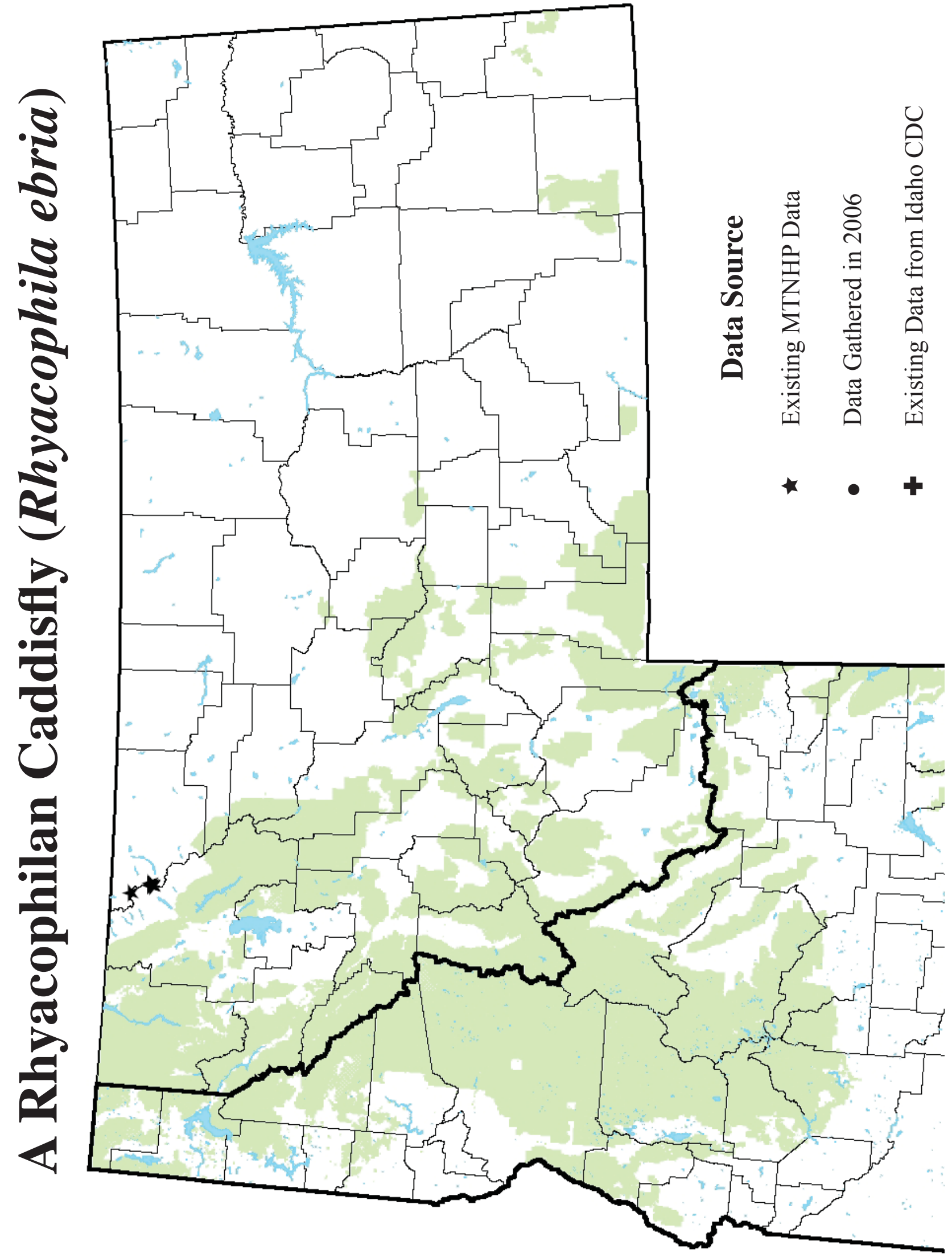




\section{Species Abundance}

These snowmelt species of Rhyacophila (glaciera \& ebria) are reported to be fairly rare and very low in abundance even in the proper habitat.

\section{Current Status}

\section{A. Why Species is of Conservation Concern}

R. ebria is a regional endemic only known to occur in high alpine snowmelt and spring fed streams along the Rocky Mountain Cordillera in Glacier National Park of Montana, Waterton, Banff and Jasper National Parks of Alberta \& British Columbia. With the increased evidence of global warming, this species could be considered a candidate for the USFWS T\&E species list.

\section{B. Threats}

Specific threats to Montana populations of R. ebria would include global warming and the melting of glaciers. If the existing glaciers disappear from Glacier National Park, as predicted in 25 years (2030-2040)(Daniel Fagre, pers comm.), this species will likely be extirpated from the state and possibly extinct. In general, cold-stenothermic (cold-water specialists) invertebrate populations are affected by changes to aquatic habitat, such as alteration of flow patterns, streambed substrate, thermal characteristics, and water quality.

\section{Distribution Relative to Land Allocations}

In Montana, R. ebria is unlikely to occur outside of Glacier National Park (Glacier and Flathead Counties) managed by the National Park Service, and thus, has little management implications at the Northern Region 1 Forest Service level. 
SPECIES: Rhyacophila glaciera

Heritage Rank: G3, MT: S1

Natural History

\section{A. Taxonomy}

Order: Trichoptera

Family: Rhyacophilidae

Rhyacophila glaciera Denning 1965

Denning (1965) described R. glaciera from Logan Pass Creek, Glacier National Park, Montana (Newell and Potter 1973), but since then has been found in Alberta and British Columbia (Geirsch 2002, Nature Serve 2006). This species is included in the $R$. alberta species group which includes four other species found in Montana (Gustafson 2007). The mis-spelled glacieri seems to also be in use for this species.

\section{B. Species Description}

Adult Morphology: Forewing 8-9.5 mm, transparent yellowish with some cross-veins surrounded with smoky brown, giving them a gray speckled appearance on apical half. Head brown, setal warts lighter. Antennae brown. Legs yellowish brown, tibiae lighter apically (see Denning 1965 for detailed adult description).

Larval Morphology: Mature larvae are $\sim 10 \mathrm{~mm}$. Posterior margin of frontoclypeus with dark pattern, obscuring distinct muscle scars. Head wedge shaped, narrowing in anterior half, light brown with darkened muscle scars, darker areas laterally; posterior margin of frontoclypeus with dark shading, separate muscle scars indistinct; maxillary palpus stout, second segment slightly longer than first; left mandible with single apical tooth, right mandible with three apical teeth, one small mesal tooth. Pronotum brown with several darkened muscle scars posteriorly (Giersch 2002).

Reproductive Biology: In Montana, adults have been collected from mid-August through early October.

Ecology: R. glaciera is isolated to the northern Rocky Mountains, where it lives in cold alpine streams fed by permanent snowmelt or icefields. Nimmo (1971) reported this species from small, turbulent creeks to tiny alpine trickles, Along with $R$. ebria Denning, this species occurs in the highest, coldest streams in Glacier National Park. This species has also been collected with $R$. glaciera pupating and emerging simultaneously with $R$. alberta (J. Giersch, personal observation).

\section{Range and Known Sites}

Rangewide Distribution: R. glaciera is a regional endemic only known to occur in high alpine snowmelt and spring fed streams along the Rocky Mountain Cordillera in Glacier National Park 


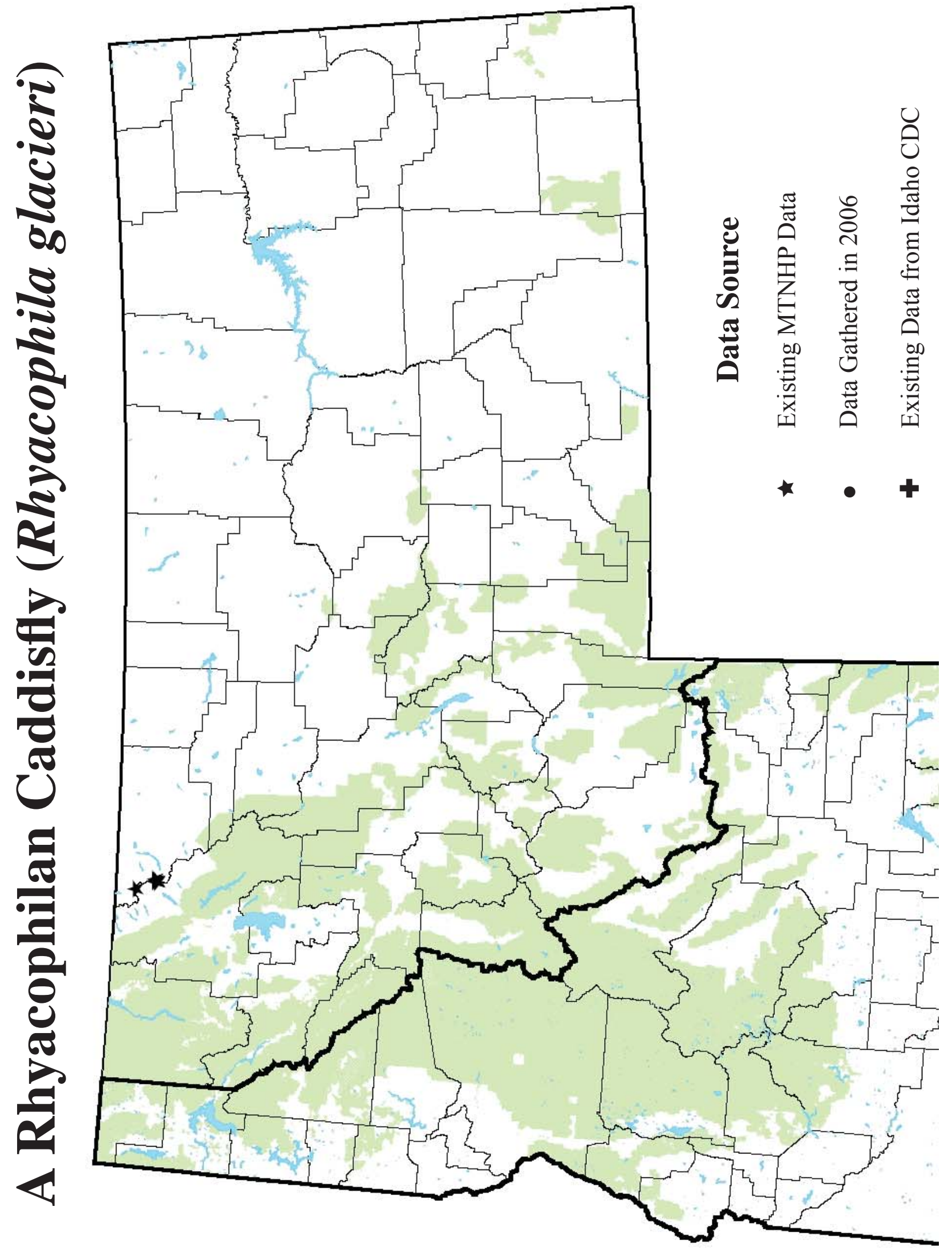


of Montana, Waterton, Banff and Jasper National Parks of Alberta \& British Columbia (Wiggins 1996, NatureServe 2006). This distribution may be associated with a glacial refugium in the area. In Montana, R. glaciera is unlikely to occur outside of Glacier National Park (Glacier and Flathead Counties) and thus, has little management implications at the Northern Region 1 Forest Service level.

\section{Species Abundance}

These snowmelt species of Rhyacophila (glaciera \& ebria) are reported to be fairly rare and very local in abundance even in the proper habitat.

\section{Current Status}

\section{A. Why Species is of Conservation Concern}

R. glaciera is a regional endemic only known to occur in high alpine snowmelt and spring fed streams along the Rocky Mountain Cordillera in Glacier National Park of Montana, Waterton, Banff and Jasper National Parks of Alberta \& British Columbia. With the increased advancement of global warming, this species could be considered a candidate for the USFWS T\&E species list.

\section{B. Threats}

Specific threats to Montana populations of R. glaciera would include global warming and the melting of glaciers. If the existing glaciers disappear from Glacier National Park, as predicted in 25 years (2030-2040)(Daniel Fagre, pers comm.), this species will likely be extirpated from the state and possibly extinct. In general, cold-stenothermic (cold-water specialists) invertebrate populations are affected by changes to aquatic habitat, such as alteration of flow patterns, streambed substrate, thermal characteristics, and water quality.

\section{Distribution Relative to Land Allocations}

In Montana, $R$. glaciera is unlikely to occur outside of Glacier National Park (Glacier and Flathead Counties) which is managed by the National Park Service, and thus, has little management implications at the Northern Region 1 Forest Service level. 
SPECIES: Rhyacophila newelli

Heritage Rank: G2, MT: S2

Natural History

\section{A. Taxonomy}

Order: Trichoptera

Family: Rhyacophilidae

Rhyacophila newelli Denning 1971
A Rhyacophilan Caddisfly

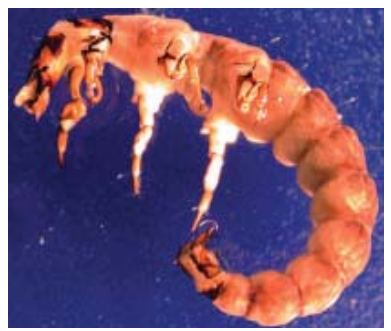

Photo of Rhyacophila newelli was unavailable. Photo shows a generalized Rhyacophila angelita grp. larva.

Type Locality: Rattlesnake Creek, Missoula Co., Montana The larvae of Rhyacophila newelli were identified from an adult male collected in Montana (Denning 1971). Because Rhyacophila newelli is a member of the R. angelita species group (2 other species in MT) (Gustafson 2007), and no larval key is available, reports of site occurrences with $R$. angelita group ( 42 records in the databases) could potentially contain this rare species, but we could not be sure without mature pupae or adults to verify it.

\section{B. Species Description}

Adult Morphology: See Denning 1971 for detailed adult description.

Larval Morphology: Body length: $12-15 \mathrm{~mm}$. Head usually wedge-shaped with patterning, no gills on the abdominal segments, apical extension off of the anal claw present (see photo).

Reproductive Biology: Adults were collected in mid-July (Denning 1971), other than that not much is known of this species.

Ecology: This species is associated with high gradient, perennially flowing headwater springs and streams (Wiggins 1966). These caddisfly larvae are free-living and move actively searching for food (predatory) with no case, until just before pupation. The trophic relationship of Rhyachophila is usually predatory on other insects, especially chironomids (midge larvae) and simulids (blackfly larvae) (Merritt and Cummins 1996).

\section{Range and Known Sites}

Rangewide, Rhyacophila newelli is a regional endemic only known to occur in Montana (Newell \& Potter 1973), Alberta \& British Columbia (Wiggins 1996, NatureServe 2006).

Distribution data for U.S. states and Canadian provinces is known to be incomplete or has not been reviewed for this taxon. Known from Rattlesnake Creek, Missoula Co., Montana (Newell and Potter, 1973); also in Alberta. It is unclear how a distribution map would look given the limited knowledge.

\section{Species Abundance}

These species of Rhyacophila can be rather abundant in the proper habitat, but are usually fairly rare and very local in abundance (Wiggins 1996). 


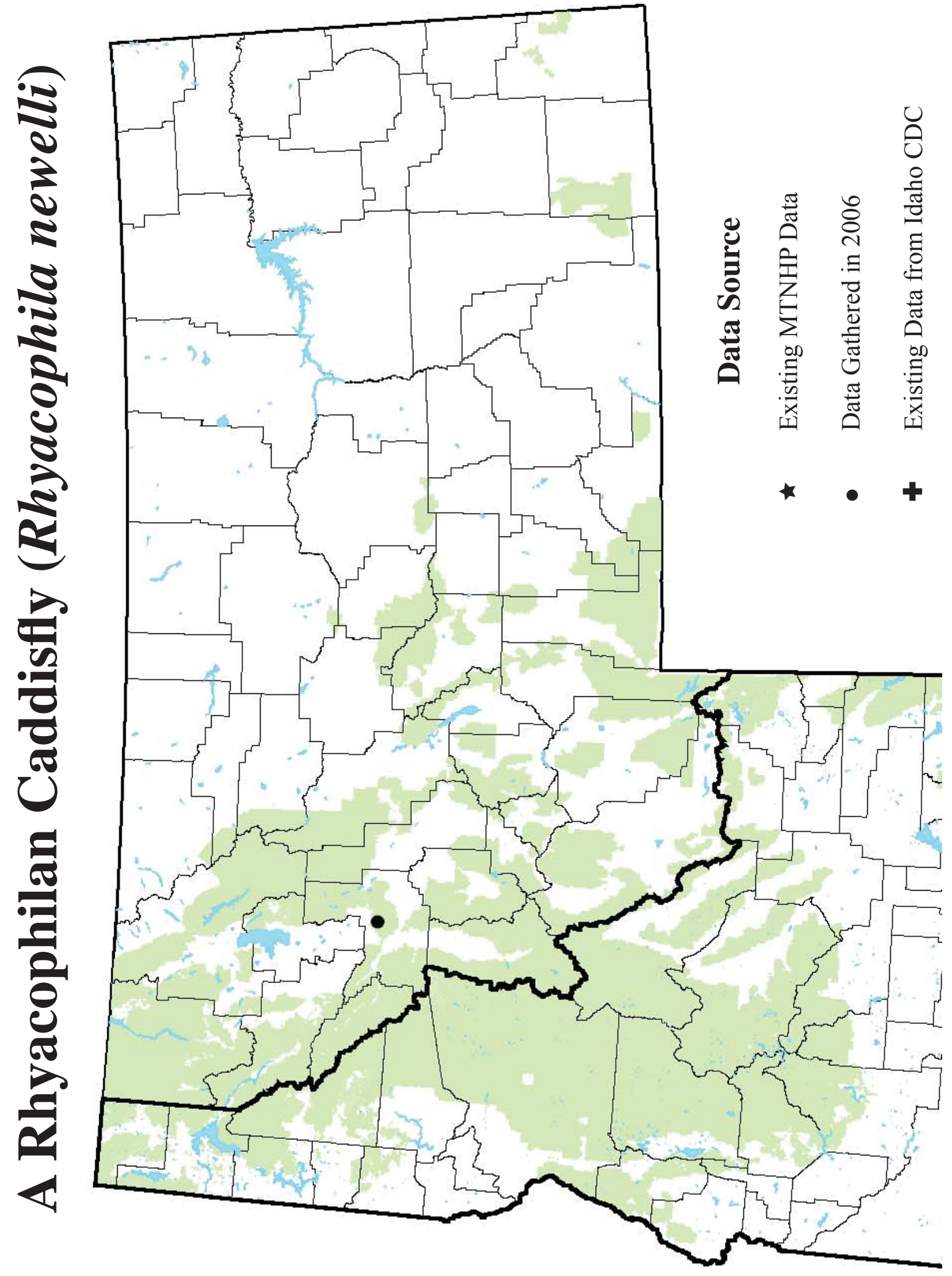




\section{Current Status}

\section{A. Why Species is of Conservation Concern}

Limited data and the inability to identify larval collections has lead to a low global rank. Distribution data for U.S. states and Canadian provinces is known to be incomplete or has not been reviewed for this taxon.

\section{B. Threats}

Specific threats to Montana populations of $R$. newelli would include mismanagement of forested riparian areas, including sediment and temperature increases associated with road building and timber harvests not following BMPs. In general, cold-stenothermic (cold-water specialists) invertebrate populations are affected by changes to aquatic habitat, such as alteration of flow patterns, streambed substrate, thermal characteristics, and water quality. Alteration and degradation of riparian and aquatic habitat is the primary concern for Montana populations.

\section{Distribution Relative to Land Allocations}

Given the lack of locality information; it is difficult to assess the area of Rattlesnake Creek that the type specimen was collected, although given the habitat requirements, we plotted the point high up in the watershed. The potential for this species to occur in the Lolo National Forest is very high 


\section{Heritage Rank: G1G2, ID：SNR MT：SNR}

\section{Natural History}

\section{A. Taxonomy}

Order: Trichoptera

Family: Uenoidae

Sericostriata surdickae Wiggins Weaver and Unzicker 1985

Photo of Sericostriata surdickae larvae on a granite rock face taken by D. Gustafson.

The larvae of Sericostriata surdickae were identified from an associated series of larvae, and mature pupae collected in Montana (Wiggins 1996).

\section{B. Species Description}

Adult Morphology: Taxonomy of adults is covered in Wiggins et al. (1985). The adults are known as Little Western Dark Sedges.

Larval Morphology: Body length: 8-10 mm. Larvae of Sericostriata surdickae could be confused with larvae of Farula and Neothremma, but are readily distinguished by the angulate anterolateral corners of the pronotum and mesonotum. The ventral apotome of the head of Sericostriata is longer and separates the gena more than in related genera. The transverse banding and longitudinal ridges of the larval case of Sericostriata is also considerably different from that of Farula and Neothremma.

Reproductive Biology: In Idaho, collections indicate that at least 2 years are required to complete the life cycle. Adults of this species emerge from mid-July to mid-August (Wiggins 1996).

Ecology: The larvae of $S$. surdickae occur on the upper surfaces of rocks in high gradient, perennially flowing, cold mountain streams (Wiggins1996, see photo). The trophic relationship of Sericostriata larvae include scrapers and collectors-gatherers (detritus, diatoms) (Merritt and Cummins 1996).

\section{Range and Known Sites}

Rangewide, Sericostriata surdickae is a regional endemic only known to occur in Idaho and Montana (Wiggins 1996, NatureServe 2006).

In Montana, Sericostriata surdickae has been reported from Missoula, Mineral, Granite, Powell and Sanders Counties.

In Idaho, Sericostriata surdickae has been reported from 4 counties including Idaho and Valley County in west-central Idaho; and Elmore and Lemhi counties. 


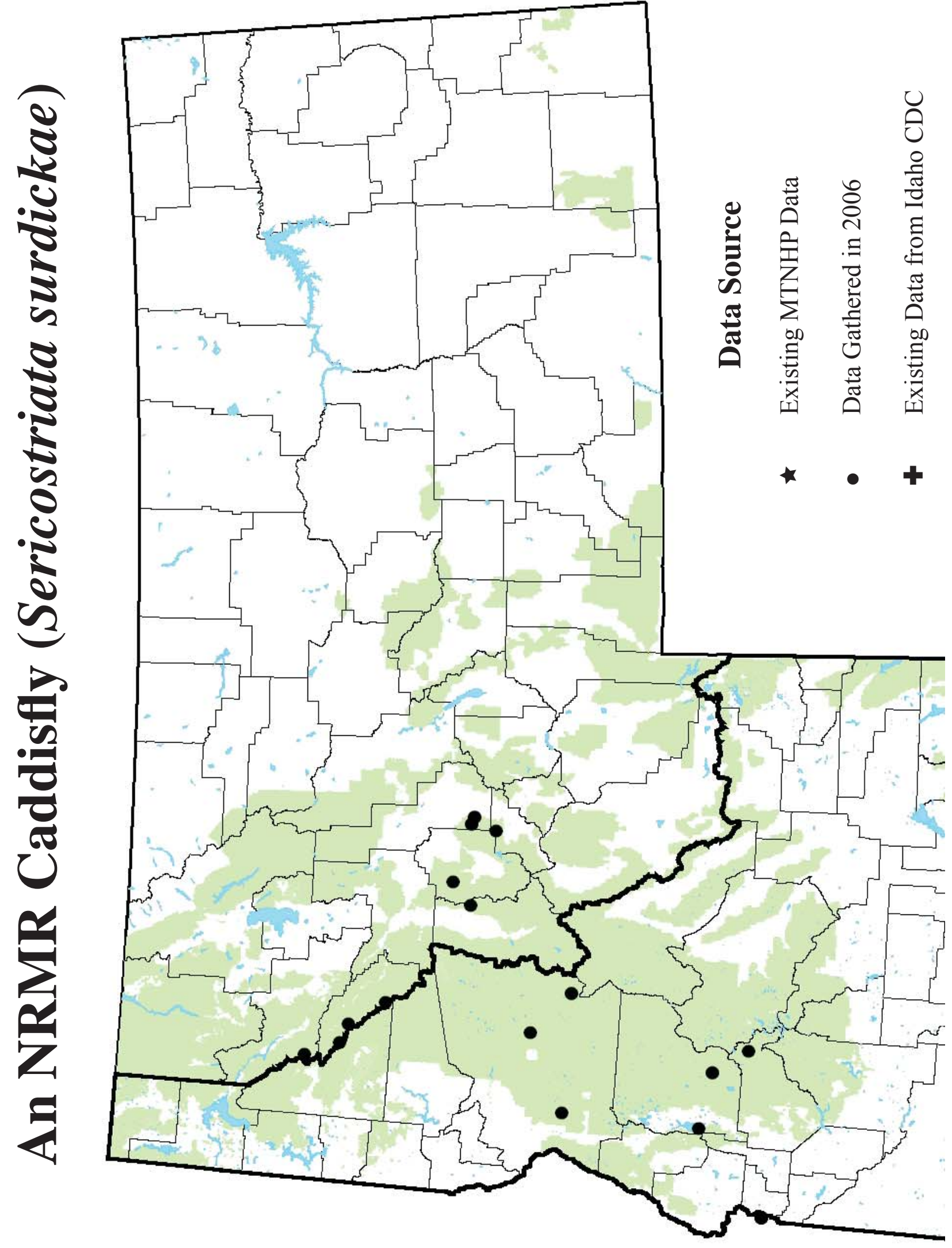




\section{Species Abundance}

Wiggins (1996) reported that this species is uncommon and very local in occurrence in the proper habitat. In the MT 2006 samples, 10 was the highest number of individuals found in any sample.

\section{Current Status}

\section{A. Why Species is of Conservation Concern}

Sericostriata surdickae has been described as a rare species due to habitat specificity and is never abundant when collected (Wiggins 1996). It has no USFWS status at the present time, although it is currently a US Forest Service Species of Concern (SOC); ranked globally rare/uncommon (G1G2) by Natureserve (2006), but unranked (SNR) in Montana and not yet reported for Idaho.

\section{B. Threats}

Specific threats to Montana \& Idaho populations of $S$. surdickae would include mismanagement of forested riparian areas, including sediment and temperature increases associated with road building and timber harvests not following BMPs. In general, stenothermic (cold-loving) invertebrate populations are affected by changes to aquatic habitat, such as alteration of flow patterns, streambed substrate, thermal characteristics, and water quality. Alteration and degradation of riparian and aquatic habitat is the primary concern for Idaho and Montana populations.

\section{Distribution Relative to Land Allocations}

All specimens of Sericostriata surdickae collected in Montana and Idaho were collected from drainages on public lands within the Clearwater, Salmon-Challis and Lolo National Forests. The high elevation, steep gradient, forested-headwater stream type that these caddisflies inhabit dictates that their entire distribution will likely occur on National Forest Service Lands. 
SPECIES: Rossiana montana

Heritage Rank: G2G3, MT: SNR

Natural History
A Northern Rocky Mountain Refugium Caddisfly

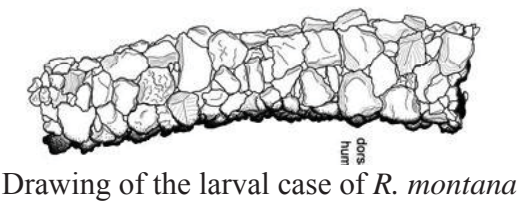

\section{A. Taxonomy}

Order: Trichoptera

Family: Rossianidae

Rossiana montana Denning 1973

The larvae of Rossiana montana were identified from an associated series of larvae, and mature pupae collected in Montana (Wiggins 1996).

\section{B. Species Description}

Adult Morphology: Morphology of adults is described by Denning 1973.

Larval Morphology: Body length: up to $10 \mathrm{~mm}$. Unusual case-makers (see photo) and the posteriolateral margins of the head are extended as prominent flanges. The head and pronotal areas are brownish-red and coarsely pebbled. Mandibles have separate tooth-like points.

Reproductive Biology: Pupae and late-instar larvae were collected in June, so adults may be flying from late-June to July.

Ecology: This species is associated with high-gradient, $1^{\text {st }}$ or $2^{\text {nd }}$ order, perennially flowing springs and streams (especially in gravel under mossy areas, Wiggins 1996). The trophic relationship of larvae of $R$. montana include scrappers and shredders (eating detritus \& plant materials) (Merritt and Cummins 1996, Wiggins 1996).

\section{Range and Known Sites}

Rangewide, Rossiana montana is a regional endemic only known to occur in western Montana, Washington and British Columbia (Wiggins 1996, NatureServe 2006).

In Montana, Rossiana montana has been reported from streams in Missoula, Mineral and Sanders counties. Rossiana montana has not been reported in Idaho yet, but it is likely to be found in the NRMR area (Clearwater National Forest) near the MT border.

\section{Species Abundance}

Wiggins (1996) reported that this species is rare and very low in abundance even in the proper habitat. 


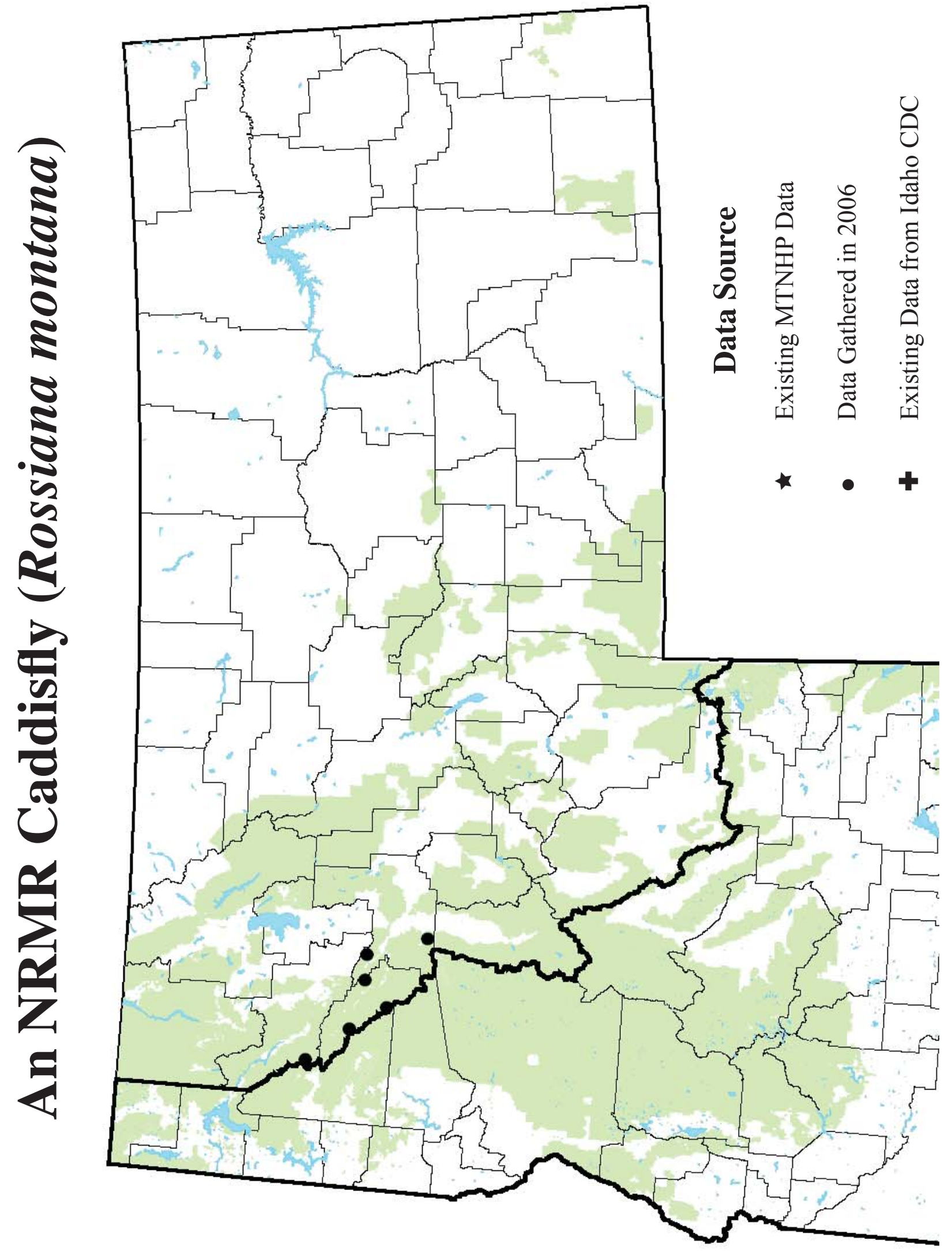




\section{Current Status}

\section{A. Why Species is of Conservation Concern}

Rossiana montana has been described as a rare species due to habitat specificity and is never abundant when collected (Wiggins 1996). It has no USFWS status at the present time, although it is currently a US Forest Service Species of Concern (SOC); ranked globally rare/uncommon (G2G3) by Natureserve (2006), but unranked (SNR) in Montana and not yet reported for Idaho.

\section{B. Threats}

Specific threats to Montana populations of $R$. montana would include mismanagement of forested riparian areas, including sediment and temperature increases associated with road building and timber harvests not following BMPs. In general, cold-stenothermic (cold-water specialists) invertebrate populations can be affected by slight changes to the thermal characteristics of their aquatic habitats, such as alteration of flow patterns, increased sunlight exposure, streambed substrate and water quality. Alteration and degradation of riparian and aquatic habitat is the primary concern for these populations.

\section{Distribution Relative to Land Allocations}

All specimens of $R$. montana collected in Montana were collected from drainages on public lands within the Lolo National Forest. It would not be surprising to discover this species in similar habitats in the Clearwater National Forest in Idaho. The steep forested-headwater stream type that these mayflies inhabit dictates that much of their distribution will likely occur on US Forest Service Lands. 
SPECIES: Goereilla baumanni

Heritage Rank: G1G2, ID: SNR, MT: SNR

Natural History

\section{A. Taxonomy}

Order: Trichoptera

Family: Rossianidae

Goereilla baumanni Denning 1973
A Northern Rocky Mountain Refugium Caddisfly

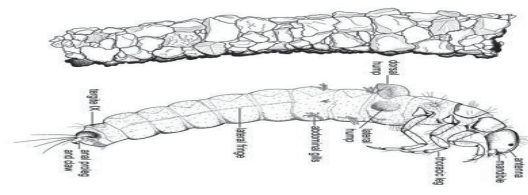

Drawing of Goereilla baumanni larvae and case.

The species, Goereilla baumanni were described from an associated series of adults collected in Montana (Denning 1973). A more detailed account of the larvae, pupae and adults can be found in Wiggins (1996) where larvae from Montana were reared.

\section{B. Species Description}

Adult Morphology: See Denning 1973 for detailed adult description.

Larval Morphology: See Wiggins 1996 for detailed larval and pupa descriptions. Body length: up to $9 \mathrm{~mm}$ for mature larvae. Larvae have single abdominal gills and lack chloride epithelial. Larvae of G. baumanni could be confused only with larvae of Rossiana montana, but their head lacks a flange or carina as in R. montana. G. baumanni larvae also have a slightly extended mesiepisternum into a spiny lobe. Larvae are found in first order streams where they are found in side-channel seepage areas (Wiggins 1996). Larvae construct smooth tubular cases of small rock and some sand grains (see drawing).

Reproductive Biology: In Montana, adults of this species emerge from mid-July to midAugust (Wiggins 1996).

Ecology: This species is associated with high elevation, forested, perennially flowing cold spring seep areas (Wiggins 1996). The trophic relationship of larvae of G. baumanni include shredders and collectors-gatherers (eating detritus \& plant pieces) (Merritt and Cummins 1996, Wiggins 1996).

\section{Range and Known Sites}

Rangewide, G. baumanni a regional endemic is only known to occur in the Northern Rocky Mountain Refugium area of Montana and Idaho (Wiggins 1996, NatureServe 2006). In Montana, G. baumanni has been reported from two counties including Missoula, and Mineral. In Idaho, G. baumanni has been reported from one stream in Clearwater County.

\section{Species Abundance}

These species of caddisfly are reported to be fairly rare and very low in abundance even in the proper habitat (e.g. only 1 or 2 reported in any sample). 


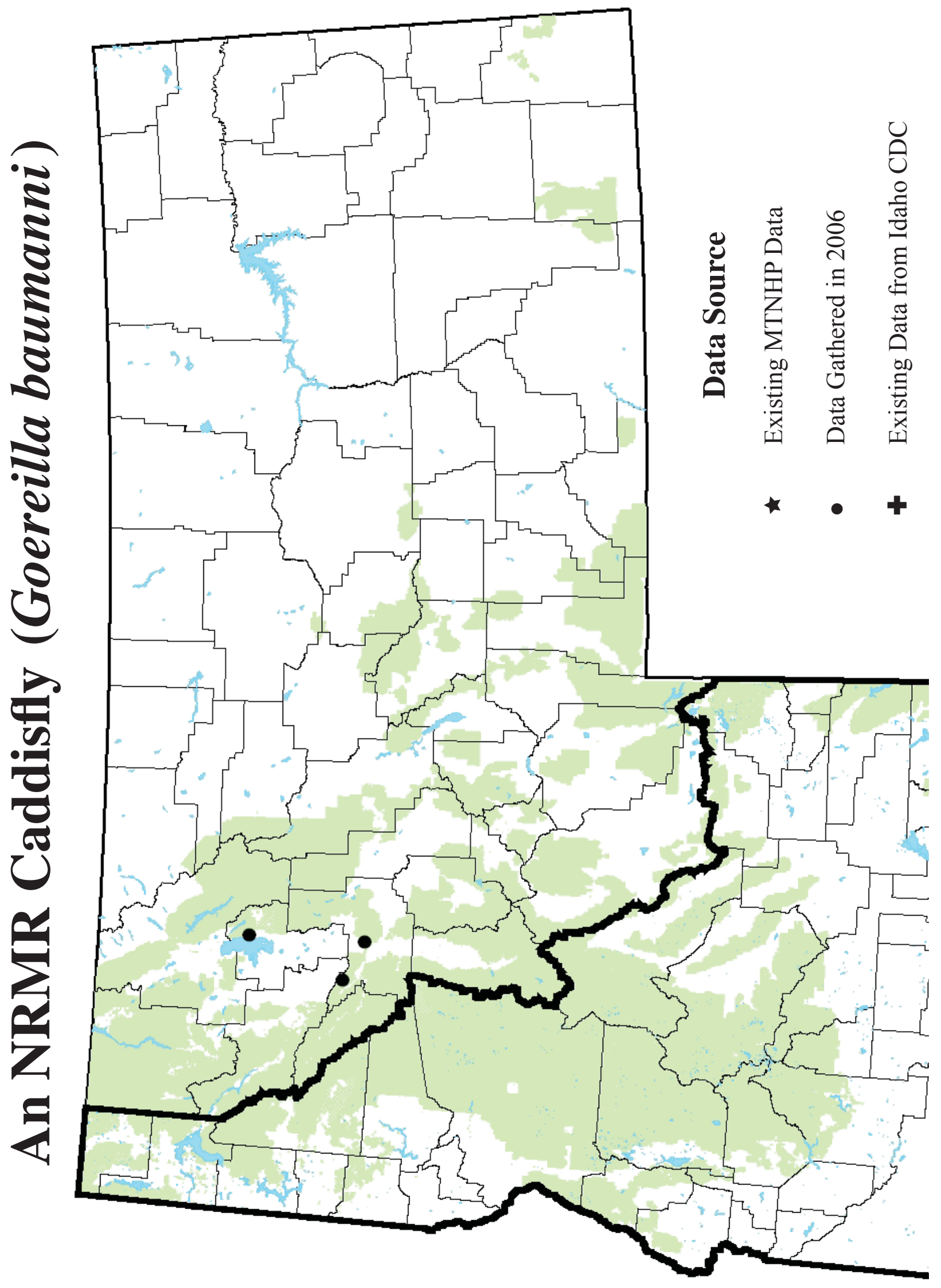




\section{Current Status}

\section{A. Why Species is of Conservation Concern}

Goeriella baumanni has been described as a rare species due to habitat specificity (Wiggins 1996) and is never abundant when collected. It has no USFWS status at the present time, although it is currently a US Forest Service Species of Concern (SOC); ranked globally uncommon (G1G2) by Natureserve (2006), but unranked (SNR) in Idaho and Montana.

\section{B. Threats}

Specific threats to Montana \& Idaho populations of G. baumanni would include mismanagement of forested riparian areas, including sediment and temperature increases associated with road building and timber harvests not following BMPs. In general, stenothermic (cold-loving) invertebrate populations are affected by changes to aquatic habitat, such as alteration of flow patterns, streambed substrate, thermal characteristics, and water quality. Alteration and degradation of riparian and aquatic habitat is the primary concern for Idaho and Montana populations.

\section{Distribution Relative to Land Allocations}

All specimens of Goeriella baumanni collected in Montana and Idaho were collected from drainages on public lands within the Clearwater and Lolo National Forests. The high elevation forested-headwater stream type that these caddisflies inhabit dictates that their entire distribution will likely occur on National Forest Service Lands. 


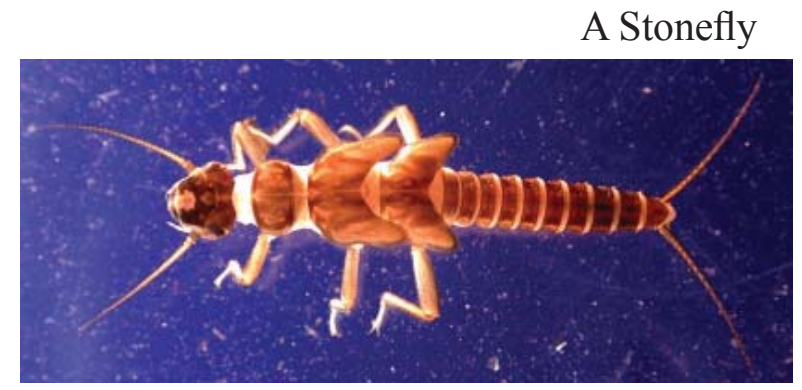

Photo of a closely related Perlodidae, but not $P$. expansa

Order: Plecoptera

Family: Perlodidae

Pictetiella expansa (Baumann and Gaufin 1971)

Type Locality of P. expansa is in Grant, CO.

This species was originally described in the genus Perla and was later included in the genus Isogenus (Pictetia) before being placed in its own genus Pictietiella which was monospecific, containing the one species, expansa (Baumann et al. 1977), until a new species Pictetiella lechleitneri was described in Washington (Stark and Kondratieff 2004).

\section{B. Species Description}

Larval Morphology: Length of larval male is $15-16 \mathrm{~mm}$; length of mature female is 17$21 \mathrm{~mm}$. The general color is brown but quite strikingly patterned. Head pattern is light on a dark background that has short sub-mental gills, but no thoracic gills. The cerci of the nymphs are distinctly black-tipped, a character that could only be confused with the genus Perlinoides (Baumann et al. 1977). The nymph of conspecific, P. lechleitneri differs from P. expansa most conspicuously by the paired pale tergal patches on abdominal segments 2-10 (Stark and Kondratieff 2004).

Adult Morphology: The epiproct of Pictetiella lechleitneri is shorter and broader near the apex than in P. expansa, and the color pattern is more striking with conspicuous femoral bands and broad U-shaped posteromesal, sternal patches on abdominal segments 5-8. The female subgenital plate structure is very similar to $P$. expansa but the female can probably be separated by the banded femoral character. (Stark and Kondratieff 2004).

Reproductive Biology: Baumann et al. (1977) state that adults emerge from July through October across the species' range. Newell and Minshall (1979) report adult emergence during September at two Idaho locations, and there is often asynchronous emergence of males and females, males emerging first. Drumming, as a means of communication between males and females, has been demonstrated in P. expansa in laboratory reared individuals (Maketon and Stewart 1984).

Ecology: Nymphs generally occur in small, fast-moving streams and require high water quality. Individuals have been encountered at elevations between 555-1255 $\mathrm{m}$ in north Idaho (Idaho Department of Environmental Quality Beneficial Use Reconnaissance Program Database). This species occurs in creeks and small streams (Baumann et al. 1977; NatureServe 2006). The trophic relationship of P. expansa is likely a predator (mainly on Chironmidae and Simulidae) as are most other Perlodidae in this sub-family (Merritt and Cummins 1996). 


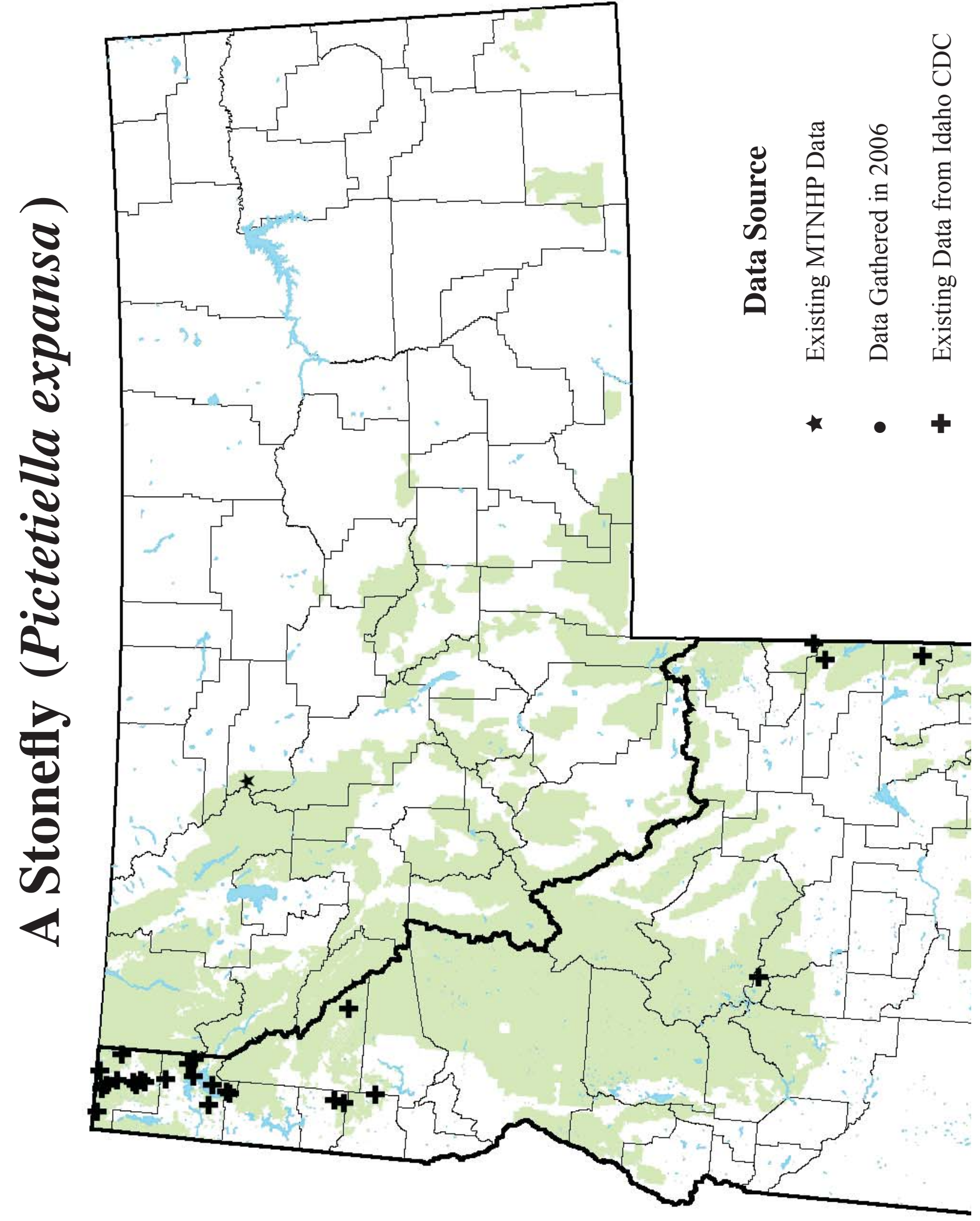




\section{Range and Known Sites}

Rangewide, this stonefly occurs in the high elevation Rocky Mountains of Colorado, Idaho, Montana, Utah, and Wyoming (Baumann, Gaufin, and Surdick 1977; Newell and Minshall 1979).

In Idaho, P. expansa is known from 26 streams in Boundary, Bonner, Shoshone, Clearwater, Benewah, Blaine, Caribou, Bonneville, Teton counties (Baumann personal communication 2005, Idaho Department of Environmental Quality 2005, Newell and Minshall 1979).

In Montana, $P$. expansa has only been reported from three localities in Flathead, Glacier and Gallatin Counties, of which only 1 was detailed enough to be mapped (Baumann et al. 1977).

\section{Species Abundance}

For the site records, the numbers of individuals collected by the Idaho Department of Environmental Quality (personal communication 2005) ranged widely from 9 to 528 specimens per sampling station. In MT fewer than 10 individuals were recorded per site, suggesting that the species may be relatively uncommon in all its occupied reaches. Baumann et al. (1977) considered this species to be uncommon, although nymphs can be locally abundant in some areas. Newell and Minshall (1979) report the species as being "rare."

\section{Current Status}

\section{A. Why Species is of Conservation Concern}

Pictetiella expansa has no USFWS status at the present time, although it is currently a US Forest Service Species of Concern (SOC); listed as imperiled in Idaho (S2) and unranked in (SNR) in Montana. This species is irregularly distributed in parts of the northern and central Rocky Mountains, and populations have been poorly documented through much of this range (e.g., see Natureserve 2006). Baumann, Gaufin, and Surdick (1977) describe P. expansa as "uncommon." Newell and Minshall (1979) report the species as "rare and restricted in its distribution." More recently, in 1994-1995, the IDDEQ (personal communication 2005) found this species in 22 northern Idaho streams, sometimes in large numbers. The broad west-to-east and north-to-south distribution in Idaho, the number of Idaho streams from which this species has been collected, and the numbers of specimens collected per station by the IDDEQ indicate this species might not be as rare or uncommon in Idaho as earlier publications suggest. Field inventories are needed to learn more about the status and distribution in the Northern Region 1 managed forest lands.

\section{B. Threats}

Specific threats to populations of $P$. expansa have not been identified. In general, stonefly populations are affected by changes to aquatic habitat, such asalteration of flow patterns, streambed substrate, thermal characteristics, and water quality. Degradation of riparian and aquatic habitats is the primary concern for population occurring within USFS Region 1. 


\section{Distribution Relative to Land Allocations}

Most (12 of 22) sites containing P. expansa collected in the Idaho Panhandle and central mountains of Idaho and in Montana were collected from drainages on public lands within the Idaho Panhandle, Clearwater, Nez Perce and Flathead National Forests (Idaho Department of Environmental Quality, personal communication 2005). Nine sites were reported on private lands, and 1 appears to be within state land. Based on available specimen label information, two specimens at Brigham Young University (Baumann personal communication 2005) are from streams in National Forests. Two other collections (Newell and Minshall 1979) were made on streams that flow through National Forest at upper elevations and private lands at lower elevations; not enough information is provided about those specimens to determine associated land ownership. The moderate to steep gradient forested type that these stoneflies inhabit dictates that much of their distribution will likely occur on National Forest Service Lands. 
SPECIES: Soyedina potteri

Heritage Rank: G3, ID: S1, MT: SNR

Natural History

\section{A. Taxonomy}

Order: Plecoptera

Family: Nemouridae

Soyedina potteri (Baumann and Gaufin 1971)
A Northern Rocky Mountain Refugium Stonefly

Idaho Forestfly

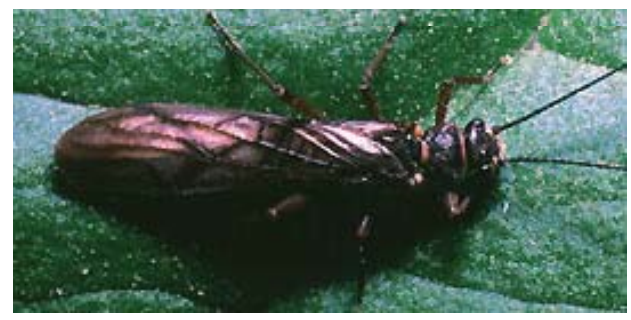

Photo of Soyedina from Washington (not potteri) taken by C. Riley used from The Tree of Life Web Project. http://tolweb.org/Nemouridae/13941

Type Locality: Butler Creek, Snow Bowl, Missoula County, Montana.

The North American endemic genus Soyedina contains one Rocky Mountain species Soyedina potteri that was first described in 1966 as Nemoura (Soyedina) interrupta (Baumann et al. 1977).

\section{B. Species Description}

Adult Morphology: Adults are macropterous and distinguished by the fusion of viens $\mathrm{A}_{1}$ and $\mathrm{A}_{2}$ in the forewing near the wing margin. Wings are hyaline; anal area of each hindwing is large. Body length is $5.5-7 \mathrm{~mm}$, forewing length is $5-6.5 \mathrm{~mm}$. General color is dark brown; legs are yellowish brown. Cerci are small and membranous. Gills are absent. See Baumann and Gaufin (1971) for more details.

Larval Morphology: Body length: $4 \mathrm{~mm}$, caudal filaments: $3 \mathrm{~mm}$. General color is light brown, head light brown and slightly patterened. No cervical gills and the pronotum rounded at the corners with a definite notch on the lateral margins.

Reproductive Biology: In Montana, the adults emerge from April to July (Baumann et al. 1977).

Ecology: This species occurs in creeks, small streams, and small springs (Baumann et al. 1977; NatureServe 2006). Merritt and Cummins (1996) describe the habitat associated with members of the genus Soyedina as "spring outflows." The morphology of the mouthparts suggests that Soyedina is well-suited for biting or shredding, thus its trophic relationships would include shredders and collectors-gatherers (detritus, algae) (Merritt and Cummins 1996).

\section{Range and Known Sites}

Rangewide, Soyedina potteri is a Northern Rocky Mountain regional endemic known to occur in Montana and Idaho (Baumann et al. 1977, NatureServe 2006).

In Idaho, S. potteri is known from 1 location in Clearwater County and 4 locations in Idaho County in the central mountainous part of the state (Baumann et al. 1977).

In Montana, S. potteri has been reported from scattered localities in Flathead and Glacier Counties (Baumann et al. 1977) (although they don't mention specific locations), and from four sites in the Northern Rocky Mountain Refugium area of Mineral and Missoula Counties in westcentral Montana (Stagliano, this study). 


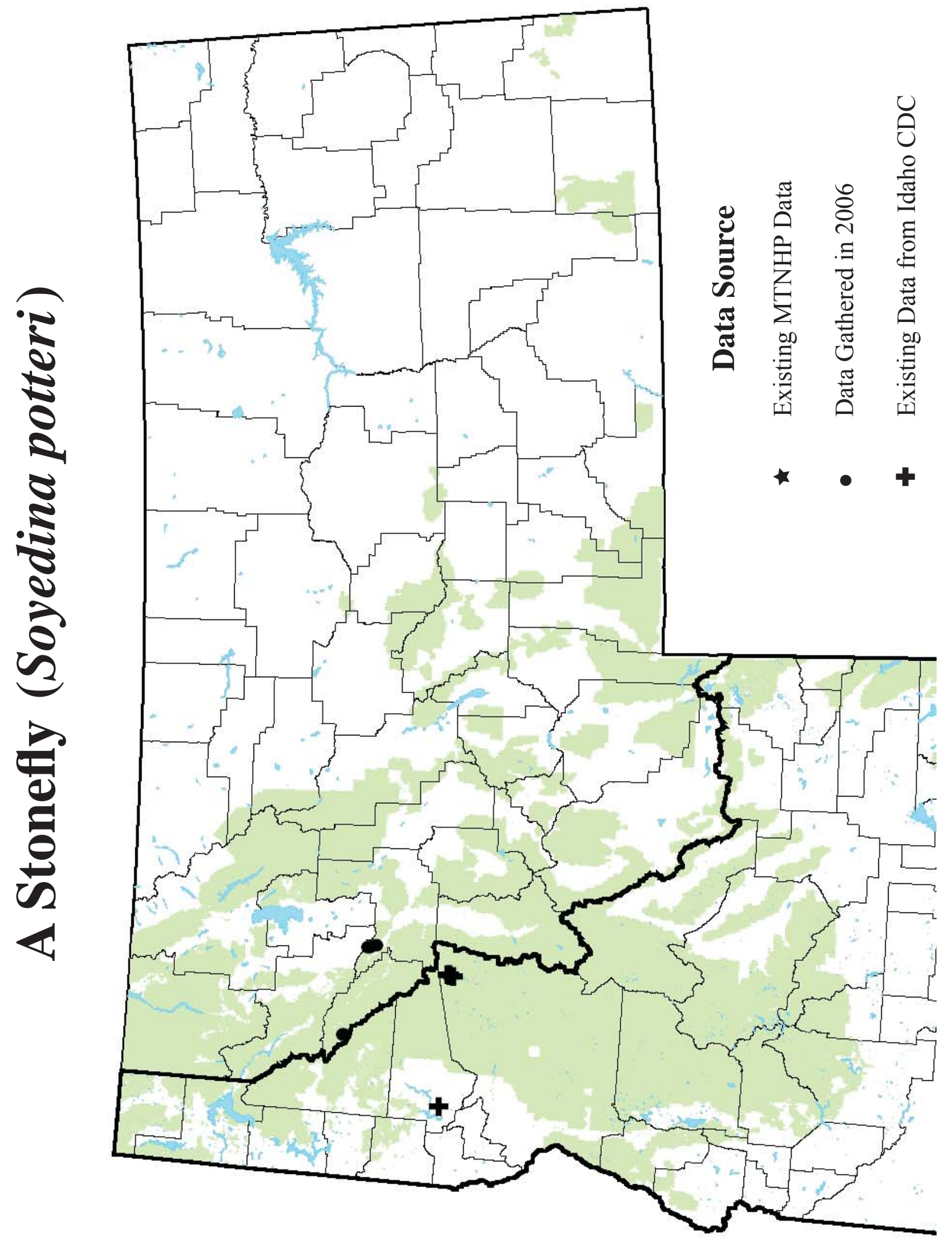




\section{Species Abundance}

This species has a narrow overall range, with specimens known only from 6 locations. In addition, the small number of available specimens suggests the species is not abundant. For the site records in ID and MT, fewer than 10 individuals were recorded per site, suggesting that the species may be uncommon in all occupied reaches.

\section{Current Status}

\section{A. Why Species is of Conservation Concern}

Soyedina potteri has no USFWS status at the present time, although it is currently a US Forest Service Species of Concern (SOC); ranked globally vulnerable (G3) by Natureserve (2006), listed as imperiled in Idaho (S1) and unranked (SNR) in Montana, but due to limited distribution will probably rank an S2. These rankings largely reflect the small number of known sites and its habitat specificity.

\section{B. Threats}

Specific threats to USFS populations of Soyedina potteri have not been identified. In general, stonefly populations are affected by changes to aquatic habitat, such as alteration of flow patterns, streambed substrate, thermal characteristics, and water quality. Alteration and degradation of riparian / aquatic habitat is the primary concern for Northern Region 1 Forest Service populations.

\section{Distribution Relative to Land Allocations}

In Idaho, 4 of the 5 documented S. potteri sites are within the Clearwater National Forest boundaries in the central mountainous part of the state. In Montana, this study reports S. potteri from 3 sites within the Lolo National Forest. 
SPECIES: Soliperla salish

Heritage Rank: G?, ID: SNR, MT: SNR

Natural History

\section{A. Taxonomy}

Order: Plecoptera

Family: Peltoperlidae

Soliperla salish Stark and Gustafson 2004

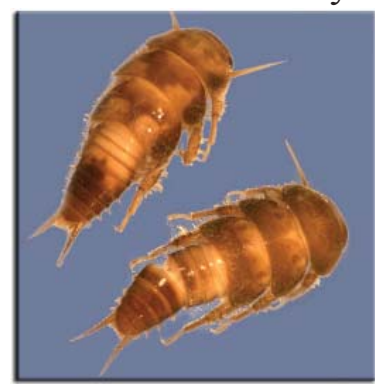

Photo of Soliperla salish taken by D. Gustafson.

Type Locality: Little North Fork Clearwater River tributary, Shoshone County, Idaho. The North American endemic genus Soliperla contains one Rocky Mountain species Soliperla salish that was recently described in 2004. Other species in this genus occur within the Pacific Northwest drainages of Washington, Oregon and California.

\section{B. Species Description}

Adult Morphology: Adults are macropterous. General color is yellowish-brown. Wings are clear and veins brown; legs are yellowish brown. Body length is $9-11 \mathrm{~mm}$; forewing length is 12 $13 \mathrm{~mm}$. Cerci are small and membranous. Gills are absent. See Stark and Gustafson (2004) for a more detailed description.

Larval Morphology: Pre-emergent length: 11-12mm. General color is light brown; head light brown with pale thorax and slightly patterned. No $\mathrm{PSC}_{1}$ gills and the posterior $\mathrm{Th}_{3}$ gill is absent. Nymphs may require 2 years to complete development based on 2 cohorts detected in collections.

Reproductive Biology: In Idaho and Montana, the adults were present late-June through July (Stark and Gustafson 2004).

Ecology: This species occurs in small high gradient creeks and streams near their headwaters source (Stark and Gustafson 2004). Nymphs were found on vertically oriented clean boulders in splash zones or seeping water, but not on the adjacent mossy covered cobbles. Merritt and Cummins (1996) describe Soliperla trophic relationships as shredders and collectors-gatherers (detritus, algae), and Stark and Gustafson (2004) reported shredded organic debris (leaves and wood) in the gut contents they examined.

\section{Range and Known Sites}

Rangewide, Soliperla salish is a Northern Rocky Mountain regional endemic known to occur only in Montana and Idaho (Stark and Gustafson 2004).

In Idaho, Soliperla salish is known from 2 locations in Clearwater County and 2 locations in Shoshone County in the central mountainous part of the state (Clearwater National Forest). In Montana, Soliperla salish has been reported at 4 locations within the Northern Rocky 


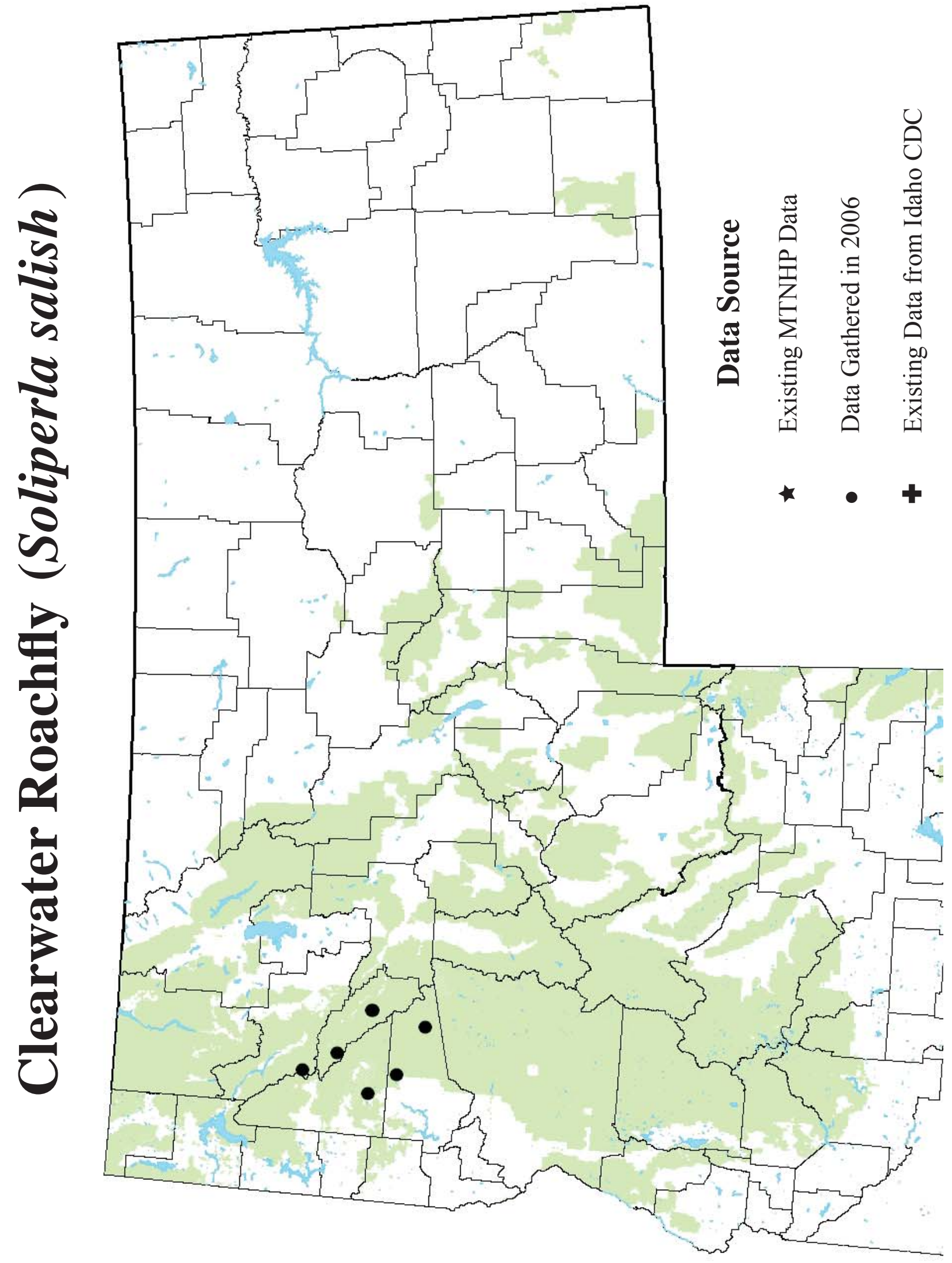


Mountain Refugium area of Mineral County in western Montana (Stark and Gustafson 2004, Stagliano, this study).

\section{Species Abundance}

This species has a narrow overall range, and specimens are known from only 7 locations. Although, some of these locations contain large numbers of individuals. Stark and Gustafson (2004) report collecting $31 \& 73$ nymphs at one site in Montana, although 2006 collections found only 3 or 4 nymphs at the 2 newly identified locations.

\section{Current Status}

\section{A. Why Species is of Conservation Concern}

Soliperla salish has no USFWS status at the present time, and since it is a fairly new species Nature Serve has not globally ranked this species yet, although given its range it will most likely be ranked globally rare to uncommon G2 or G3 based on site occurrences. Thus this species is unranked in Idaho (SNR) and unranked (SNR) in Montana and due to limited distribution will probably rank an $\mathrm{S} 2$ in both of those states.

\section{B. Threats}

Specific threats to USFS populations of Soliperla salish have not been identified. Although a population at Van Ness Creek in Montana is still viable after a forest fire burned through the area including the riparian zone (D. Gustafson, pers. comm.). In general, stonefly populations are affected by changes to aquatic habitat, such as alteration of flow patterns, streambed substrate, thermal characteristics, and water quality. Alteration and degradation of riparian / aquatic habitat is the primary concern for Northern Region 1 Forest Service populations.

\section{Distribution Relative to Land Allocations}

All specimens of Soliperla salish collected in Idaho and Montana were collected from drainages on public lands within the Clearwater and Lolo National Forests. The steep forested-headwater stream type that these stoneflies inhabit dictates that much of their distribution will likely occur on National Forest Service Lands. 
SPECIES: Taenionema umatilla

Heritage Rank: G3, ID: S1

Natural History

\section{A. Taxonomy}

Order: Plecoptera

Family: Taeniopterygidae

Taenionema umatilla Stanger \& Baumann, 1993
A Stonefly (Umatilla Willowfly)

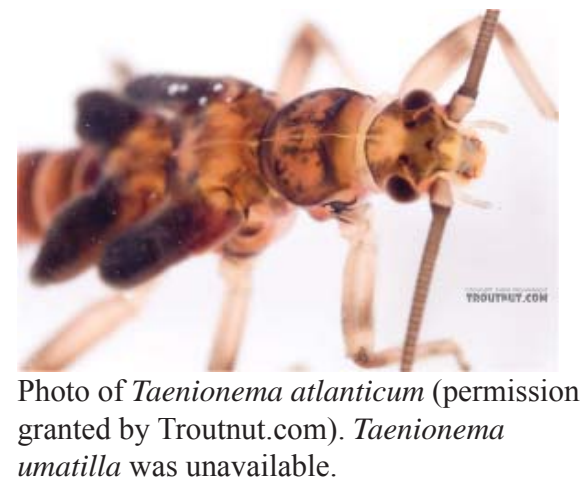

Type Locality: Meacham, Umatilla County, Oregon.

\section{B. Species Description}

Adult Morphology: Body length is 7.5-9.5 mm. Individuals are macropterous; forewing length is $8-10 \mathrm{~mm}$. Dorsum of head is brown with a light area between ocelli and around the inner margins of the compound eyes. The pronotum is brown with pale margins and dark rugosities. The thorax is brown with a medial pale, triangular area on the anterior margin of the mesonotum. Legs are yellow-brown. The wings are amber with dark veins (Stanger and Baumann 1993).

Larval Morphology: Larvae are characterized by divergent wingpads and coxae without gills, legs are uniformly brown and head and thorax have some patterning (see photo).

Reproductive Biology: Adults of this species have been collected in April and May (Stanger and Baumann 1993).

Ecology: Taenionema umatilla is known from creeks and small rivers (Stanger and Baumann 1993). Generally, species of this family are scrapers and shredders eating diatoms or plant materials (Merritt and Cummins 1996).

\section{Range and Known Sites}

T. umatilla is "known from creeks and small rivers at several adjacent localities in Oregon and Idaho." In Idaho, this species has been collected at 7 locations in Latah County (north-central Idaho)(Stanger and Baumann 1993).

\section{Species Abundance}

Stanger and Baumann (1993) describe T. umatilla as a "rarely collected species." The numbers of specimens collected at the 7 known Idaho localities range from 1 to 100 . 


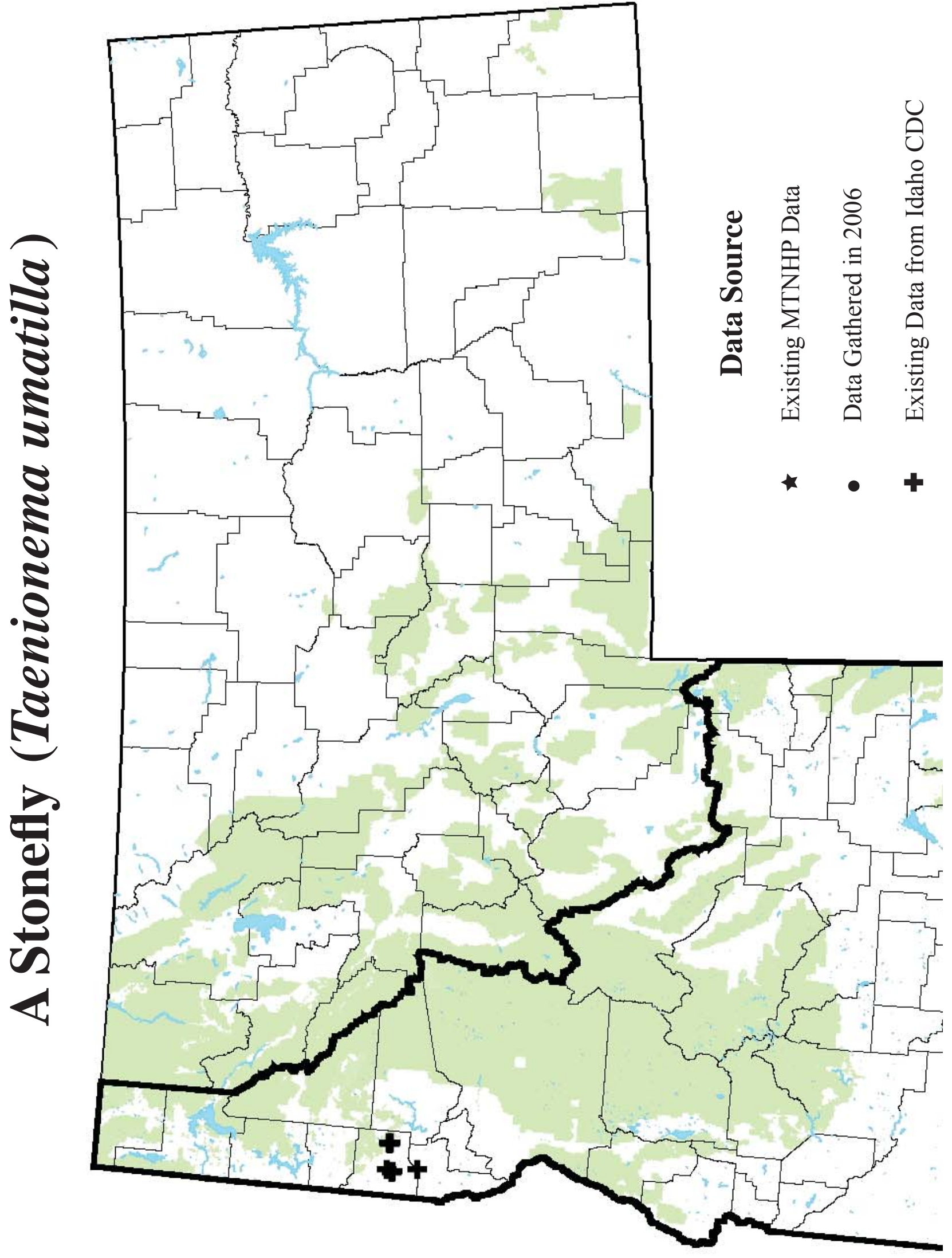




\section{Current Status}

\section{A. Why Species is of Conservation Concern}

This species has a narrow overall range, and Idaho specimens are known from only 7 locations in a single county (Stanger and Baumann 1993).

\section{B. Threats}

Specific threats to Idaho populations of Taenionema umatilla have not been identified. In general, stonefly populations are affected by changes to aquatic habitat such as alteration of flow patterns, streambed substrate, thermal characteristics, and water quality. Alteration and degradation of aquatic habitat is the primary concern for Idaho populations.

\section{Distribution Relative to Land Allocations}

Based on available specimen information, 5 of the 7 collection sites in Idaho are definitely or likely within private lands. Two collection sites appear to be within the Clearwater National Forest. 
SPECIES: Zapada cordillera

Heritage Rank: G3, ID: S1 MT: S2

Natural History

\section{A. Taxonomy}

Order: Plecoptera

Family: Nemouridae

Zapada cordillera (Baumann and Gaufin 1971)

Type Locality: Butler Creek, Missoula County, Montana (Baumann and Gaufin 1977). This rare Rocky Mountain species, Zapada cordillera, was first described in 1971 as Nemoura (Zapada) cordillera (Baumann \& Gaufin 1971).

\section{B. Species Description}

Adult Morphology: Adult morphology described in Baumann et al. (1977) (see photo).

Larval Morphology: Larvae have not been associated with the adults or distinguished from other Z. oregonensis group species, thus larvae would be identified to the species group level by taxonomy labs identifying bioassesment samples.

Reproductive Biology: In Montana, the adults emerge from March to May (Baumann et al. 1977).

Ecology: This species occurs in spring-influenced creeks and small streams (Baumann et al. 1977; NatureServe 2006). The morphology of the mouthparts suggests that Zapada cordillera is well-suited for shredding plant materials, thus trophic relationships would include being shredders and collectors-gatherers (detritus, CPOM) (Merritt \& Cummins 1996).

\section{Range and Known Sites}

Rangewide, Zapada cordillera is known from scattered localities in California, Oregon, Washington, Idaho and Montana (Baumann et al. 1977, NatureServe 2006). Occurrences in the Northern Rocky Mountain region (Montana and Idaho) appear to be disjunct glacial refugium populations (Gustafson 2001).

In Idaho, Z. cordillera has only been reported from Sherman Creek in Idaho County (Baumann et al. 1977).

In Montana, Z. cordillera has been reported from scattered localities in Flathead and Glacier Counties, and from the Northern Rocky Mountain Refugium area of Mineral and Missoula Counties in west-central Montana (Baumann et al. 1977, Stagliano, unpublished data). 


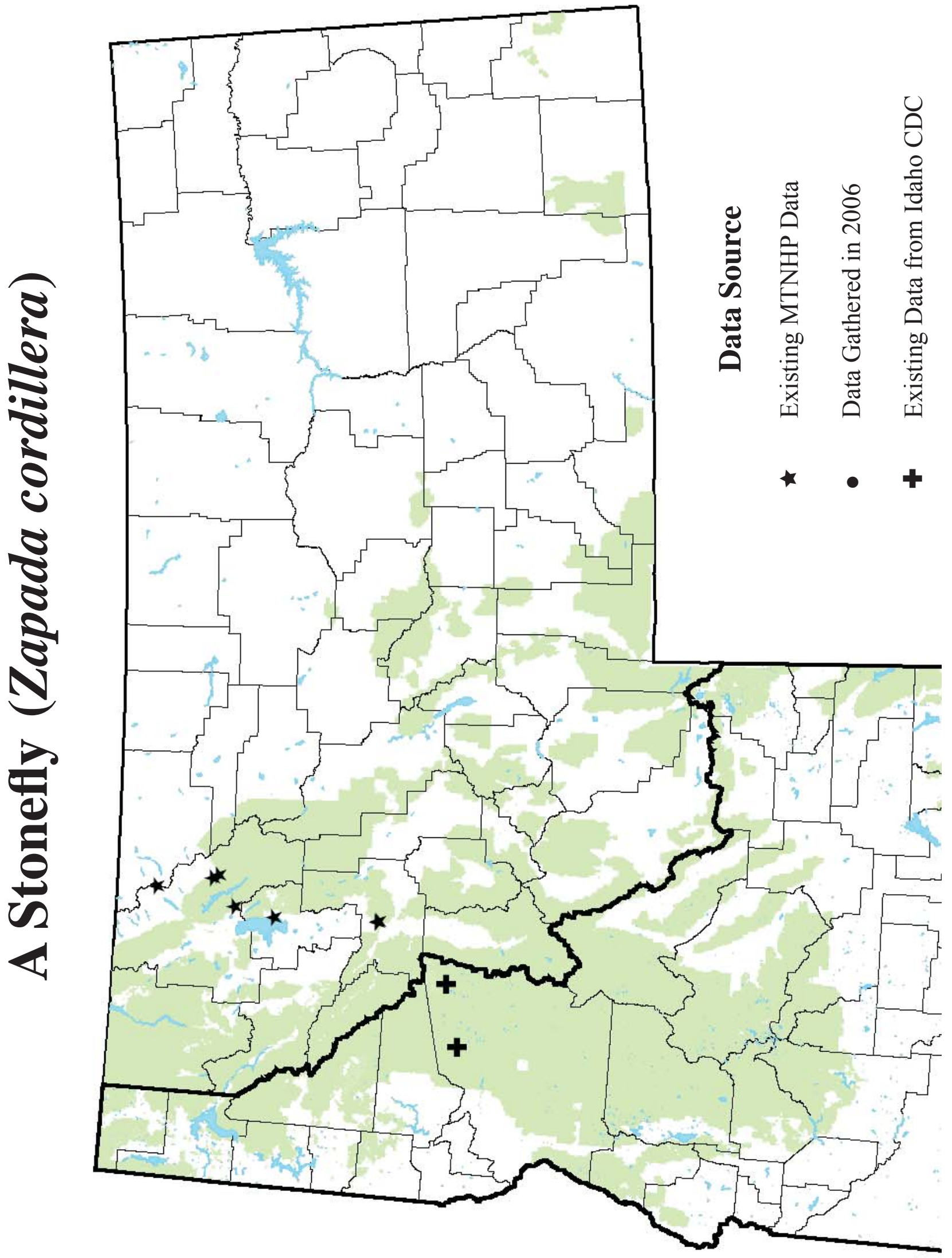




\section{Species Abundance}

For the site records we have in MT fewer than 10 individuals were recorded per site, suggesting that the species may be relatively rare and in low abundance in all its occupied reaches.

\section{Current Status}

\section{A. Why Species is of Conservation Concern}

Zapada cordillera has been described as a rare species due to habitat specificity (Baumann et al. 1977) and is never abundant when collected. It has no USFWS status at the present time, although it is currently a US Forest Service Species of Concern (SOC); ranked globally uncommon (G3) by NatureServe (2006), listed as imperiled in Idaho (S1) and threatened (S2) in Montana.

\section{B. Threats}

Specific threats to USFS populations of $Z$. cordillera have not been identified. In general, cold-water stonefly populations are affected by changes to aquatic habitat, such as alteration of flow patterns, streambed substrate, thermal characteristics, and water quality. Alteration and degradation of riparian and aquatic habitat is the primary concern for Northern Region 1 Forest Service populations

\section{Distribution Relative to Land Allocations}

All specimens of Z. cordillera collected in Montana and Idaho were collected from drainages on public lands within the Clearwater, Lolo and Flathead National Forests. The high elevation forested-headwater stream type that these stomeflies inhabit dictates that their entire distribution will likely occur on lands managed by the US Forest Service. 
SPECIES: Zapada glacier

Heritage Rank: G2, MT: S1

\section{Natural History}

\section{A. Taxonomy}

Order: Plecoptera

Family: Nemouridae

Zapada glacier (Baumann and Gaufin 1971)

This rare Rocky Mountain species, Zapada glacier, was first described in 1971 as Nemoura (Zapada) glacier (Baumann and Gaufin 1971) from adult males and females. The type species was collected from Cataract Creek, Glacier County, MT.

\section{B. Species Description}

Larval Morphology: Larvae have not been associated with the adults or distinguished from other Z. oregonensis group species, although they share the typical characters of the group: cervical gills simple, unbranched and not constricted past the base (see photo of full view larva). Thus this species would not be identified to species and left within this species group level by taxonomy labs identifying bioassesment samples.

Adult Morphology: Adults described in Baumann and Gaufin (1971) (see photo of adult).

Reproductive Biology: In Montana, the adults have been collected in July (Baumann et al. 1977).

Ecology: This species occurs in steep (precipitous) glacial-influenced streams (Baumann et al. 1977; NatureServe 2006). The morphology of the mouthparts suggests that Zapada glacier is well-suited for shredding plant materials, thus trophic relationships would include being shredders and collectors-gatherers (detritus, CPOM) (Merritt \& Cummins 1996).

\section{Range and Known Sites}

Rangewide, Zapada glacier is known only from Glacier National Park, Montana, but may also occur in Waterton Park, Alberta, but is difficult to collect (glacier-fed streams) at high elevations early in the year. Only about five occurrences are known.

In Montana, Z. glacier has been reported from scattered localities in Glacier Park, including Cataract Creek, Iceburg, Grinnell, Ptarmigan and Wilbur Creeks below glaciers or glacial lakes (Baumann and Gaufin 1971). 


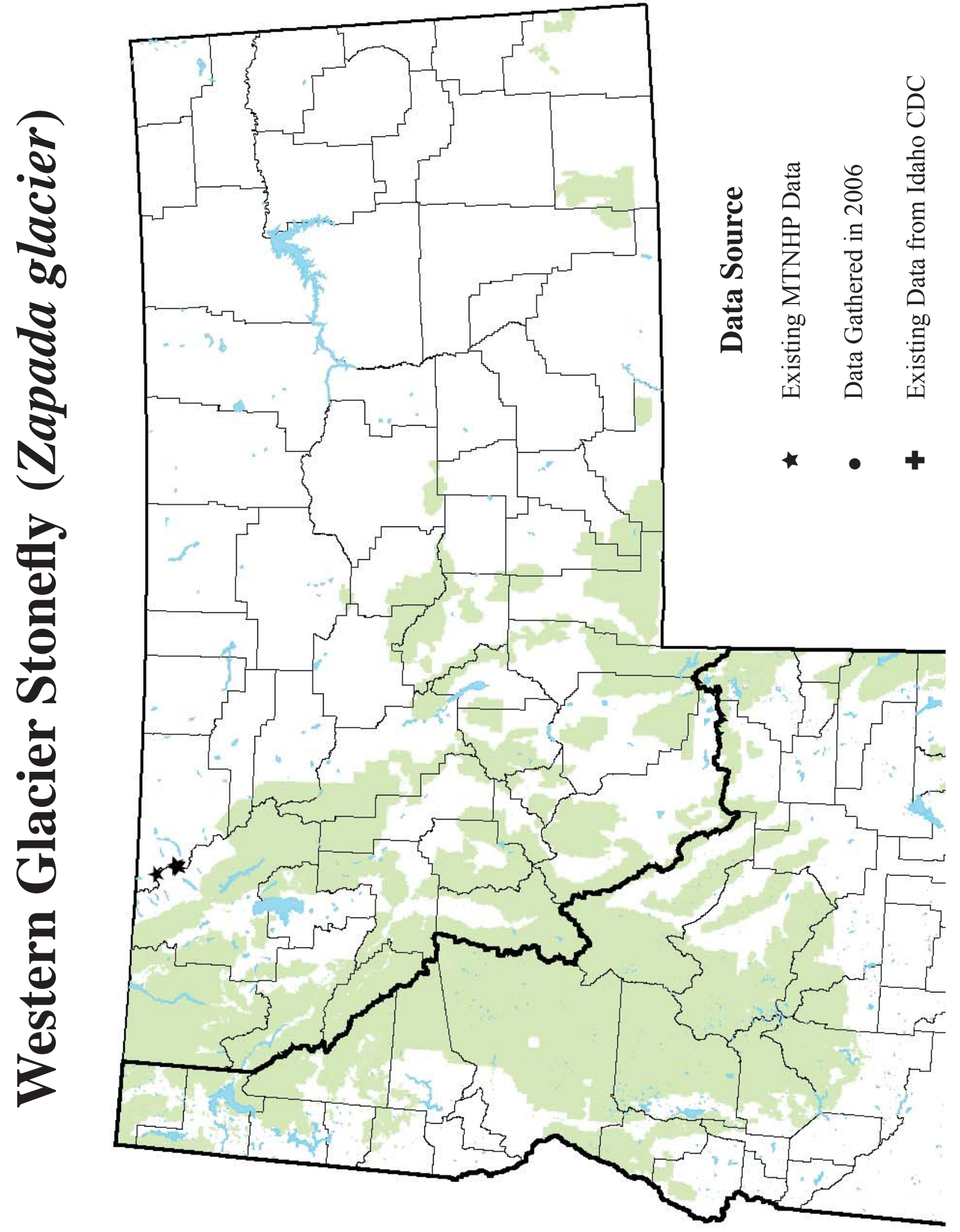




\section{Species Abundance}

For the site records in Glacier National Park, MT, fewer than 10 individuals were recorded per site, suggesting that the species is relatively rare and in low abundance in all its occupied reaches.

\section{Current Status}

\section{A. Why Species is of Conservation Concern}

Zapada glacier is a rare regional endemic only known to occur from Glacier National Park, Montana (where it is only known from five sites), but may also occur in Waterton Park, Alberta. With the increased evidence of global warming, this species could be considered a candidate for the USFWS T\&E species list.

\section{B. Threats}

Specific threats to Montana populations of Z. glacier would include global warming and the melting of glaciers. If the existing glaciers disappear from Glacier National Park, as predicted in 25 years (2030-2040) (Daniel Fagre, pers comm.), this species will likely be extirpated from the state and possibly become extinct. In general, cold-stenothermic (cold-water specialists) invertebrates are affected by changes to aquatic habitat, such as alteration of flow patterns, streambed substrate, thermal characteristics, and water quality.

\section{Distribution Relative to Land Allocations}

In Montana, Z. glacier is unlikely to occur outside of Glacier National Park (Glacier and Flathead Counties) (J. Geirsch, pers. comm.) which is managed by the National Park Service, and thus, has little management implications at the Northern Region 1 Forest Service level. 
SPECIES: Caurinella idahoensis

Heritage Rank: G1G3, ID: S2, MT: S3

\section{Natural History}

\section{A. Taxonomy}

Order: Ephemeroptera

Family: Ephemerellidae

Caurinella idahoensis (Allen 1984)

The monospecific genus Caurinella was described in 1984; the type species, Caurinella idahoensis, was described on the basis of a female nymph from Idaho County (Allen 1984). Edmunds and Murvosh (1995) examined the holotype and concurred that it represented a distinct, valid genus. They also examined additional Idaho specimens of $C$. idahoensis, all of which were nymphs. The type locality is presumed to be Brushy Creek in Idaho County and not "Bushy Creek" as reported by Allen (1984).

\section{B. Species Description}

Larval Morphology: Body length: 4-5 mm, caudal filaments: $3 \mathrm{~mm}$. General color of head and thorax is light brown and slightly patterned; maxillary palpi are 2-segmented. Head and thorax are without tubercles. Postero-lateral abdominal projections on abdominal segment 9 are very long and upturned at the apicies (see drawing). This character coupled with the row of long setae around the head are unique characters to the genus, Caurinella (Allen 1984). Until Jacobus and McCafferty (2004) reared and described the adult form, this species was known only from the original description of an immature individual.

Adult Morphology: Male adult length is $8.5 \mathrm{~mm}$; forewings are $9.0 \mathrm{~mm}$; caudal filaments are $11.2 \mathrm{~mm}$. Antennae are tan. Ocelli are white with reddish brown base. Thorax is drab olive green in life, light tan in alcohol. Prothorax has a strong median keel. Wings are hyaline with all veins pale; stigmatic area is lightly clouded with white. All legs are pale; each trochanter has a white spot. Abdomen is ivory white. Caudal filaments are white and relatively densely covered with short, fine setae (Jacobus and McCafferty 2004).

Reproductive Biology: Nymphs collected at the Idaho/Montana border, based on larval maturity and specimens reared in the laboratory, are likely to emerge as adults from mid-July to early-August (Jacobus and McCafferty 2004).

Ecology: This species is a listed as a coldwater stenotherm (IDDEQ 2002b) and was collected from second order perennial mountain streams with moderately swift current and cobble/gravel rock substrates. Specimens collected at Brushy Creek, Idaho County (Jacobus and McCafferty 2004) were found where the depth ranged from $15-50 \mathrm{~cm}$ and the stream width was $4-5 \mathrm{~m}$. The 


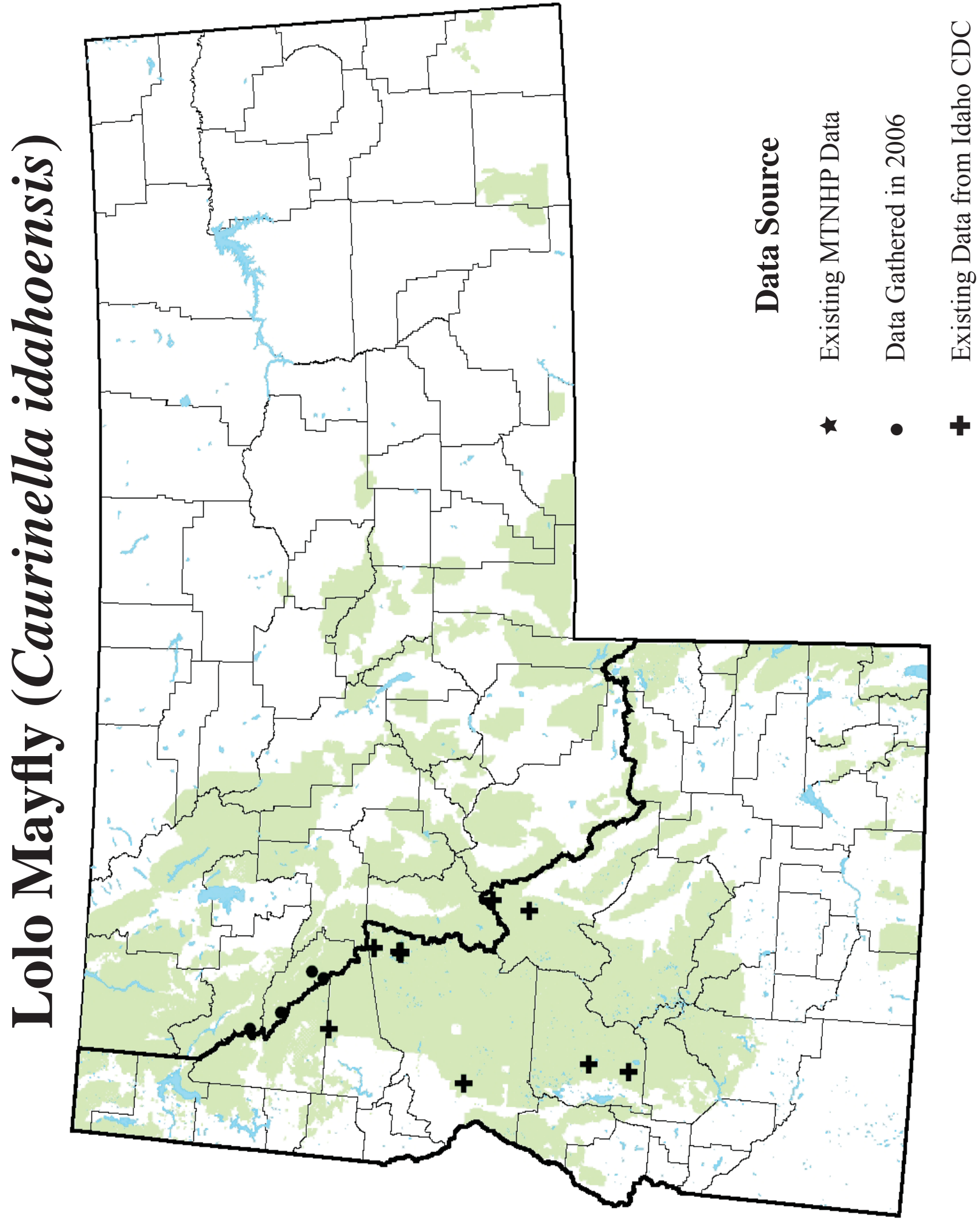


substrate was composed mostly of pale, rough cobble and boulders that were $8-30 \mathrm{~cm}$ in diameter, with some bedrock present. The riparian canopy was not completely shading the stream reach. Nymphs were found at the bases of small, ear-like macrocolonies of a blue green alga (Nostoc parmelioides), which occurred on cobble and rock surfaces exposed to the stream current. Laboratory observations indicate that larvae possibly defend small territories on rock surfaces (Jacobus and McCafferty 2004). The morphology of the mouthparts suggests that $C$. idahoensis is well-suited for scraping, biting or shredding, thus its trophic relationships would include scrapers and collectors-gatherers (detritus, algae, diatoms) (Merritt and Cummins 1996, Jacobus and McCafferty 2004).

\section{Range and Known Sites}

Rangewide, Caurinella idahoensis is a regional endemic known to occur in western Montana and Idaho (Jacobus and McCafferty 2004, NatureServe 2006).

In Idaho, C. idahoensis has been reported from scattered localities in the central mountainous part of the state from 12 locations in Valley, Lemhi, Idaho, and Clearwater counties (Edmunds and Murvosh 1995, Idaho Department of Environmental Quality personal communication 2005, Jacobus and McCafferty 2004, Gary Lester personal communication 2007). This species has been encountered in macroinvertebrate samples at 7 sites by the Idaho DEQ and in Brushy Creek as reported in Jacobus and McCafferty (2004). Fewer than 10 individuals were recorded per site, suggesting that the species may be relatively uncommon to rare in occupied reaches.

In Montana, C. idahoensis has been reported from 3 streams within the Northern Rocky Mountain Refugium area of Mineral and Missoula Counties in west-central Montana from Lolo Pass in Missoula County, north to Lookout Pass in Mineral County, Montana (Stagliano, this study) and an additional site at Prospect Creek north of Lookout Pass in Sanders County (Gustafson, unpublished data).

\section{Species Abundance}

For most of the site records in ID and MT fewer than 10 individuals were recorded per site (usually 1 or 2 specimens), suggesting that the species is relatively rare and uncommon in all of its occupied reaches.

\section{Current Status}

\section{A. Why Species is of Conservation Concern}

C. idahoensis has no USFWS status at the present time, although it is currently a US Forest Service Species of Concern (SOC); it is listed as imperiled in Idaho (S2) and a Potential Species of Concern (PSOC) (S3) in Montana. The 2006 additions to the distribution of Caurinella in a few isolated, rugged and inaccessible drainages within the greater Idaho/Montana border area indicate that, not surprisingly, this area has not been thoroughly surveyed for invertebrates. Additional surveys for this species in suitable habitats are necessary to confidently determine the regional distribution and extent of endemism to the MT / ID border region. 


\section{B. Threats}

Specific threats to Montana and Idaho populations of $C$. idahoensis have not been identified. In general, cold water stenotherm mayfly populations are affected by changes to aquatic habitat, such as alteration of flow patterns, streambed substrate, thermal characteristics, and water quality. Alteration and degradation of aquatic habitat is the primary concern for Idaho \& Montana populations. For focused evaluations, assessments should consider if human activities within the watershed can be linked to increases in stream temperature.

\section{Distribution Relative to Land Allocations}

All specimens of $C$. idahoensis collected in Montana and most of the Idaho specimens were collected from drainages on public lands within the Clearwater, Salmon-Challis and Lolo National Forests. The steep forested-headwater stream type that these mayflies inhabit dictates that much of their distribution will likely occur on National Forest Service Lands. 
Heritage Rank: G1G3, ID: SNR, MT: SNR

Natural History

\section{A. Taxonomy}

Order: Ephemeroptera

Family: Ephemerellidae

Caudatella edmundsi (Allen 1959)

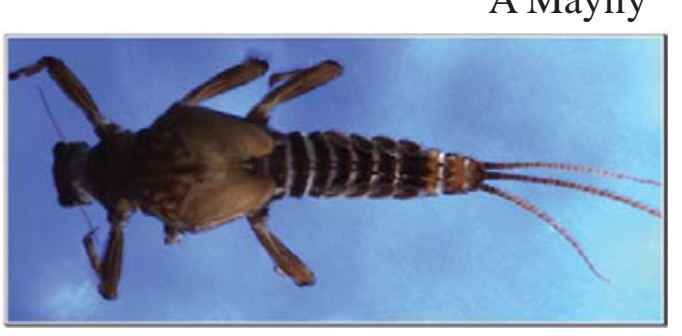

Generalized Caudatella larvae not edmundsi

Allen (1959) described this taxon based on imagos of both sexes. He described the larval form in 1961 (Allen and Edmunds 1961).

\section{B. Species Description}

Adult Morphology: see Allen (1959) for detailed description.

Larval Morphology: (See photo) Body length: 6-8 mm, robust thoracic region. Medial caudal filiament much longer than cerci. The dorsal surface of the femora has a fringe of relatively long hairs. Abdominal tergal spines on segments 3-9 are moderately long. Larvae of C. edmundsi could be confused only with larvae of $C$. hystrix, but the difference in yellowish coloration and the vestigial maxillary palpi of C. edmundsi is significant in differentiation (Jacobus 2005, pers. comm.).

Ecology: Very little is known of the habitat preference of this species (P. McCafferty, personal communication, December 2004), but like other Caudatella, this species is associated with relatively pristine, cold flowing streams and rivers (Allen 1961) and is a listed as a coldwater stenotherm (IDDEQ 2002). Hawkins (1984) found C. edmundsi \& Drunella spinifera larvae most abundant when associated with mossy cobbles and boulders in an Oregon stream (see photo). Most of the Montana collection records are from $2^{\text {nd }}-3^{\text {rd }}$ order streams capable of sustaining Westslope cutthroat trout populations with at least 50\% riparian shading and cobble/boulder substrate. Sites with this species present, visited in 2006, correlated with this stream type (avg. wetted width-2.5 $\mathrm{m}$, heavy moss growth on the cobbles). The trophic relationships of Caudatella larvae include being scrapers and collectors-gatherers (detritus, diatoms) (Merritt and Cummins 1996).

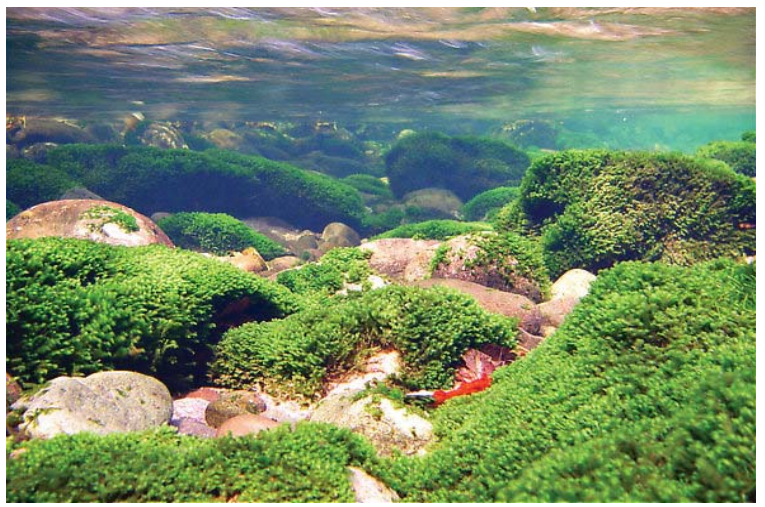

High quality Caudatella edmundsi larval habitat. 


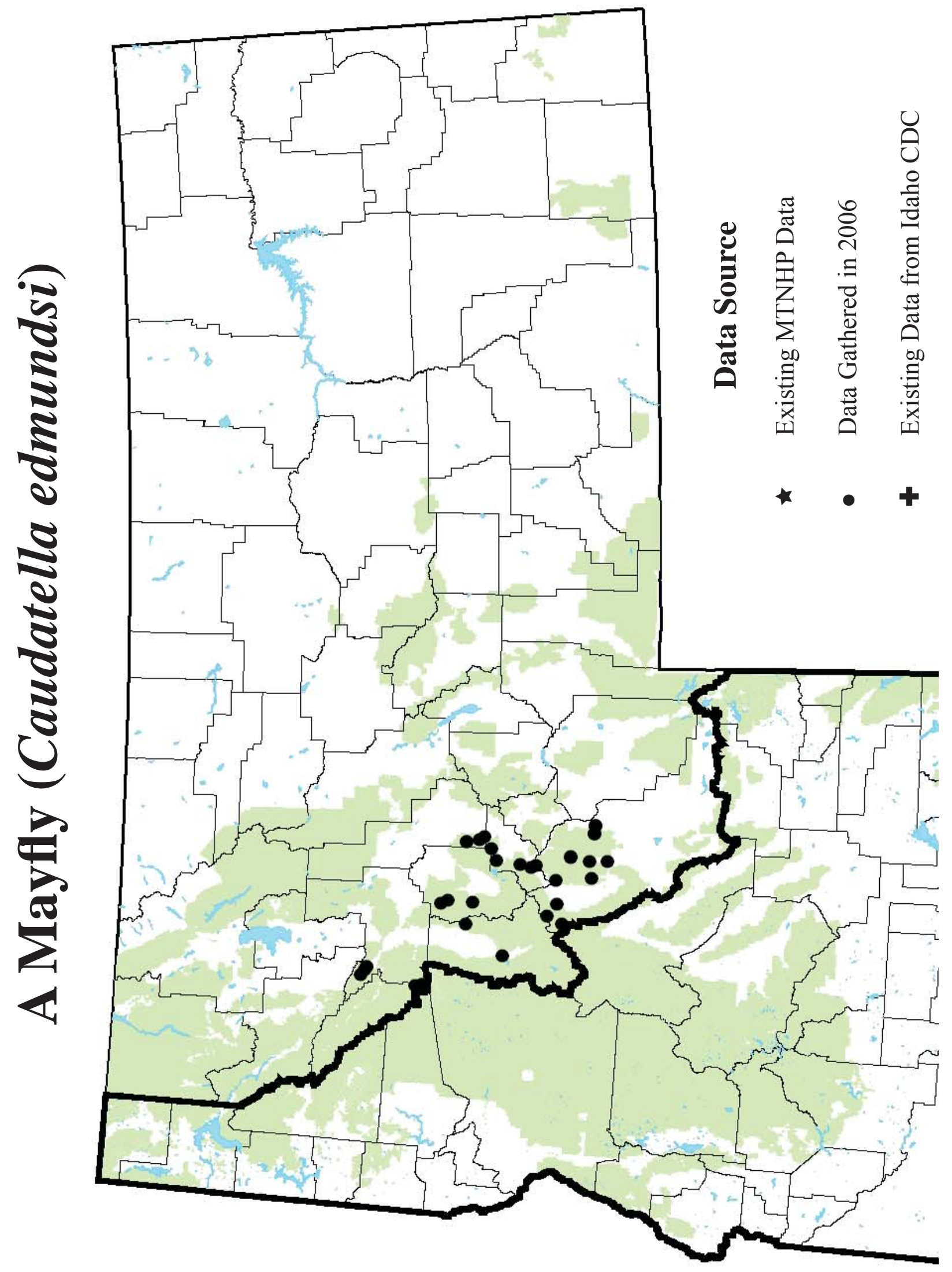




\section{Range and Known Sites}

Rangewide, C. edmundsi is known from the coastal ranges of western Oregon, and California, and more recently from disjunct Idaho and Montana populations. Until a current faunistic study of the west coast and intermountain states is complete, the current global conservation ranking is preliminary (NatureServe 2006).

In Idaho, C. edmundsi as been reported from the Snake River drainage (J. Koebaugh, pers. comm.), in Myers Creek (Idaho County) within the Nez Pearce National Forest and across the Snake river in Oregon, although specific locations were not mapped.

In Montana, C. edmundsi has been reported from 30 sites on $\sim 20$ streams in 7 counties:

Beaverhead, Deerlodge, Missoula, Mineral, Granite, Powell and Sanders Counties.

\section{Species Abundance}

This study examined the available information concerning the abundance of C. edmundsi in Montana associated with USFS PIBO data, and monitoring samples from the MT Department of Environmental Quality since 1999. In most cases, 1 or 2 specimens per sample (300-500 individuals) was reported, but in a few cases $10-30$ individuals (3-10\% of the community) were collected, indicating that given the right habitat this species can be fairly abundant in a reach.

\section{Current Status}

\section{A. Why Species is of Conservation Concern}

C. edmundsi has no federal or state agency status at the present time and was not reported to be in Montana. Although, as a result of this study, this species will be listed as a USFS SOC, and a Potential Species of Concern (PSOC) in Montana.

\section{B. Threats}

Specific threats to Montana and Idaho populations of $C$. edmundsi have not been identified. In general, cold-water mayfly populations are affected by changes to aquatic habitat, such as alteration of flow patterns, streambed substrate, thermal characteristics, and water quality. Alteration and degradation of aquatic habitat is the primary concern for Idaho \& Montana populations. For Forest Service evaluations, assessments should consider if human activities within the watershed can be linked to increases in stream temperature.

\section{Distribution Relative to Land Allocations}

Distribution of this species in the Northern Region 1 managed forest lands accounts for about half of the known occurrences. Occurrences in MT include sites in the Beaverhead-Deerlodge, Bitterroot, and the Lolo National Forests with the potential to exist in the Clearwater, Nez Perce and Salmon Forests of Idaho highly likely. The other half of the observations in MT occur on BLM managed lands or streams accessed on private lands. Since this species tends to prefer slightly larger streams with a more open canopy, mossy cobbles and moderate flow, this habitat type can also occur where National Forest lands transition to the foothills and valleys. 
Heritage Rank: G2, ID: S1

Natural History

\section{A. Taxonomy}

Order: Ephemeroptera

Family: Siphlonuridae

Parameletus columbiae McDunnough, 1938

Type Locality: Dunn Peak, N. Thompson River, British Columbia. The holotype and paratypes were captured at $2150 \mathrm{~m}$ (7000 ft) elevation.

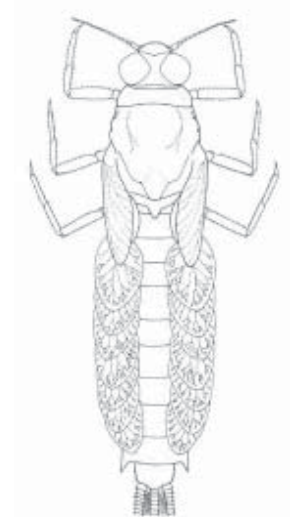

Drawing of Parameletus columbiae courtesy: http://ilmbwww.gov.bc.ca/ $\underline{\mathrm{risc} / \mathrm{pubs} / \mathrm{aquatic}}$

\section{B. Species Description}

Adult Morphology: "Head smoky black. Thorax shiny pitch-black, with slight light brown marks on mesothorax anterior to scutellum; sutures of pleura and the portion anterior to wingbase light brown with slight ruddy tinges; a brown patch at base of each leg. Abdomen deep brown dorsally, paling somewhat along anterior border of each of the first six segments; the four opaque posterior segments are shaded, especially laterally, with lighter brown: no evident markings. Ventrally much the same in color as dorsally, but somewhat ruddier; the posterior margins of the anterior segments bordered narrowly with dirty white, giving a faint ringed appearance. Tails smoky, paler at joints. Legs smoky brown, the tibiae and tarsi of prolegs almost pitch-black. Wings hyaline with deep brown longitudinal and cross veins. Length of body and forewing $11 \mathrm{~mm}$ " (McDunnough 1938).

Reproductive Biology: Eggs are deposited by females in wetlands and pools in mid-June. Eggs remain dormant during the summer and winter and "hatch within one day after the snow melts the next May." Larvae have an extremely short development period compared to other mayfly species. Larvae crawl "out of the water one or two inches onto a Carex leaf, and the subimago emerges and flies high into a tree" (Edmunds 1957). Larvae that were wild-caught and reared in the laboratory developed into subimagoes in early to mid-June. The larval stage was less than 2 weeks (Edmunds 1957).

Ecology: Merritt and Cummins (1996) consider larvae to be swimmers and climbers. Larvae are found in ponds and wetland situations on the edges of lakes in association with heavy growth of broad-leaved sedges (Carex spp.). The larvae are often concentrated where a slight current exists (Edmunds 1957). In addition to lakes and ponds, this species occurs at the edges of moderately flowing rivers and streams (Jensen 1966). Males were observed swarming high in the air over a small glacial stream with females flying over the water (McDunnough 1938). 


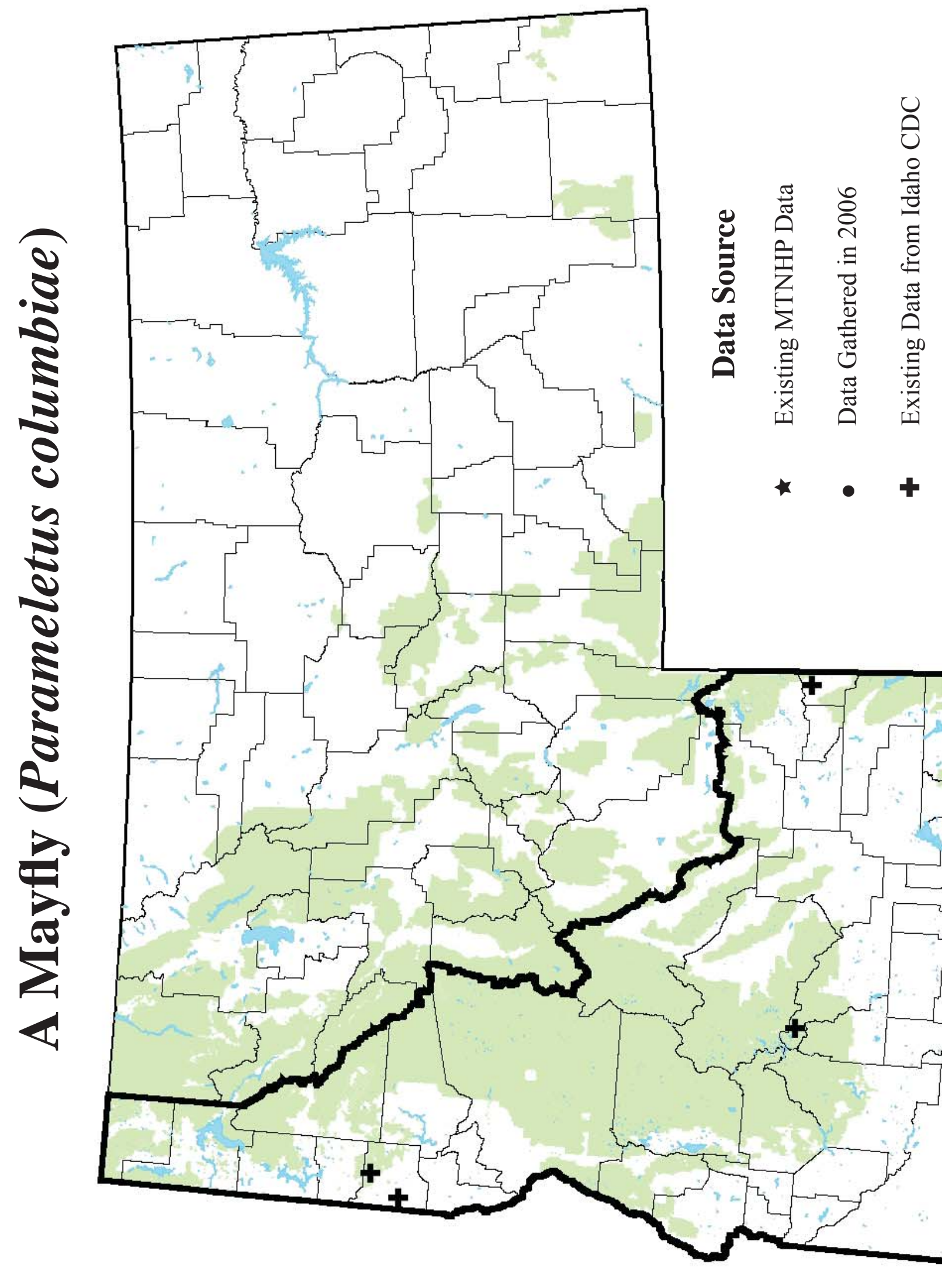




\section{Range and Known Sites}

This species is known from Idaho, Utah, Wyoming, and British Columbia (NatureServe 2006). The Idaho distribution includes 4 locations in Latah, Blaine, and Teton counties.

\section{Species Abundance}

No information is available on the abundance in Idaho.

\section{Current Status}

\section{A. Why Species is of Conservation Concern}

This species is known from very few locations in Idaho and apparently has not been collected in Idaho since 1965. Beginning in 1993, the Idaho Department of Environmental Quality (DEQ) collected aquatic invertebrates at sampling stations on Idaho streams as part of its Beneficial Use Reconaissance Program (BURP). At the end of the 2003 BURP season, a total of 5,182 stream sites had been sampled in Idaho (Idaho Department of Environmental Quality 2007). Despite annual BURP sampling efforts from 1993-2005, DEQ collected no specimens of $P$. columbiae (Idaho Department of Environmental Quality personal communication 2005).

\section{B. Threats}

Specific threats to Idaho populations of $P$. columbiae have not been identified. In general, mayfly populations are affected by changes to aquatic habitat, such as alteration of flow patterns, streambed substrate, thermal characteristics, and water quality. Alteration and degradation of aquatic habitat is the primary concern for Idaho populations.

\section{Distribution Relative to Land Allocations}

Based on available information, two of Jensen's (1966) four collection sites are within private lands. The Blaine County location is likely within National Forest lands. The fourth collection site is poorly described and could be within private land, National Forest, or State land. 
Heritage Rank: G3, ID: S2

\section{Natural History}

\author{
A. Taxonomy \\ Family: Hydrobiidae \\ Pristinicola hemphilli (Pilsbry 1890)
}

Type Locality: Near Kentucky Ferry, Snake River, WA This species was reclassified as Pristinicola hemphilli from Bythinella hemphilli (Hershler et al. 1994). No subspecies are recognized.

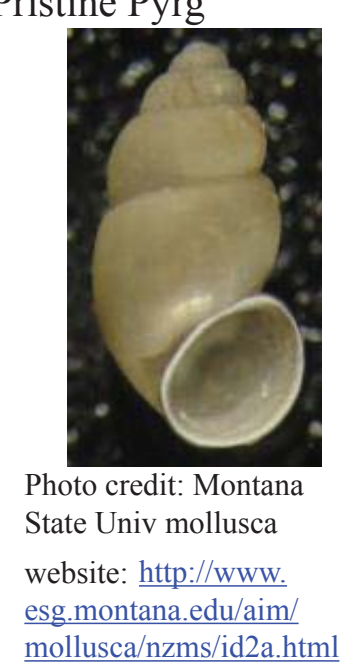

\section{B. Species Description}

Shells are 1.7-3.1 $\mathrm{mm}$ in length, narrowly conic, and consisting of 4.25-5.50 whorls (Hershler et al. 1994). Shells are operculate and dextral and can be distinguished from similar shells by a wrinkled microsculpture of the protoconch. Animal is pale, and tentacles have a uniform ciliation (Hershler et al. 1994). Hershler et al. (1994) provide detailed description of soft tissue anatomy and shells.

Reproductive Biology: Sexes are separate (unlike the majority of Idaho gastropods, which are hermaphroditic). This species is oviparous, and eggs are laid singly, attached to the sides or underneath cobbles. Most adults die after laying eggs during late winter to early spring (Hershler et al. 1994).

Ecology: This aquatic snail typically inhabits small springs or seeps and occasionally larger springs, spring outflow channels, and spring-influenced stream reaches. Springs are usually in semiarid sagebrush-dominated habitat with basalt substrates, but some sites are in dense Douglas fir forests (Frest and Johannes 1997). Habitat is characterized by cobble substrates, slow to moderate flows, and shallow, cold, clear water. Sites are relatively undisturbed (Frest and Johannes 1997). Adults are almost always found on cobbles or bedrock and infrequently in interstitial spaces in gravel (Hershler et al. 1994).

\section{Range and Known Sites}

The pristine pyrg has been reported to occur in California, Oregon, Washington, Montana and Idaho (Hershler et al. 1994). In Idaho, populations occur in portions of the lower Snake and lower Salmon river drainages (Frest 1999). From more recent snail surveys, it is not known from the middle or upper Snake River or in Montana (Richards et al 2005).

\section{Species Abundance}

No information concerning population size or population trend is available. 


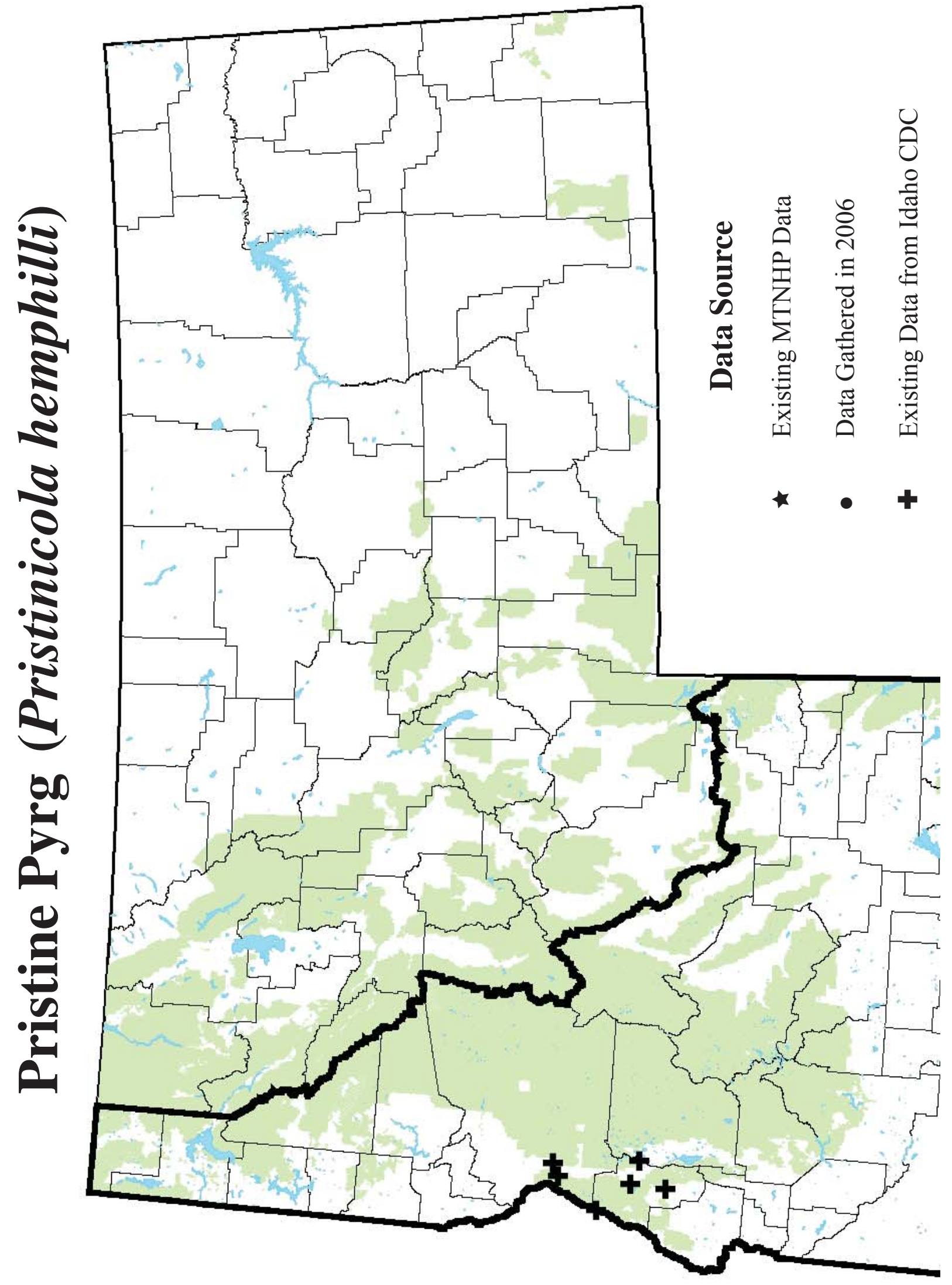




\section{Current Status}

\section{A. Why Species is of Conservation Concern}

This species is limited in distribution, occurring in widely scattered locations in the western U.S. The loss of habitat is a primary concern, although additional information is needed to clarify the current status of populations and the immediacy of threats to extant populations. Information regarding the distribution and status of populations is limited. Additional surveys are needed to clarify the location and extent of populations and to identify conservation priorities for this species.

\section{B. Threats}

Habitat loss is the primary threat to the species. According to Frest and Johannes (1997) grazing is a prevalent cause of habitat degradation. Other causes include road construction and maintenance, damming and water diversion, and campground construction. Increased nutrient load in groundwater is also a potential threat to some populations (Frest 1999).

\section{Distribution Relative to Land Allocations}

Populations occur primarily on privately owned lands, but at least one location is within lands administered by the Nez Perce National Forest (USFS Region 1) and another site is on the Payette National Forest (USFS Region 4). 
SPECIES: Fisherola nuttalli

Heritage Rank: G2, ID: S1, MT: SX

Natural History

\section{A. Taxonomy}

Class: Gastropoda

Family: Lymnaeidae

Fisherola nuttalli (Haldeman 1841)

This species was previously described as Ancylus crassus and was also known as Lanx nuttalli.

Type specimens are reported form the Lower

Columbia River near the mouth of the Willamette River in Portland and from the Spokane River in Washington.

\section{B. Species Description}

Accentric conical shell up to 0.5 inches long, 0.4 inches wide, and 0.2 inches high (Neitzel and Frest 1989). Shell small, solid, roundly ovate, slightly broader posteriorly, high-arched, apex posterior; finely concentrically striate, depressed conic (Hannibal 1912). "Shell coarse, somewhat ponderous, wide, ovate, elevated; lines of growth conspicuous; apex eroded, placed far back: anterior and lateral slopes convex, posterior slope steep and rectilinear. Color opake chesnutbrown. Dimensions: $8 \mathrm{~mm}$ long, $6.25 \mathrm{~mm}$ wide, $3 \mathrm{~mm}$ high.”.

Reproductive Biology: Freshwater pulmonates generally reproduce by copulation and crossfertilization. Eggs are laid from spring-fall in gelatinous capsules attached to plants, stones, or other objects. They lack a free-swimming larval stage, and hatch as young snails, anatomically complete except for the reproductive system (Hyman 1967).

Ecology: Found in cold, unpolluted, well-oxygenated, permanent medium-sized streams to large rivers, at least 30 meters and up to 100 meters wide. Habitats are cobble-boulder diatom covered substrate in the main channels, or close to fast-flowing water (rapids), often co-occurring with Fluminicola columbiana (Neitzel and Frest 1989, 1990). This species is not found in areas with a high abundance of macrophytes or epiphytic algae, in areas with a bedrock substrate, or in areas that are dredged or mined (Frest 1999). Fisherola nuttalli occurred primarily in the fastest waters, in a Snake River study and the probability of capturing F. nuttalli increased with increasing conductivity from 300-400 (EC) (Richards et al. 2005). This species feeds by scraping algae and diatoms from rock surfaces in the streams. May occasionally feed on other plant surfaces. Dispersal and movement is by a slow snail-like crawl or can be transported by stream current. Present all year, but not active in winter.

\section{Range and Known Sites}

Rangewide, Fisherola nuttalli is found in scattered localities in the Columbia River drainage system of the Pacific Northwest, including Idaho, Washington, Oregon, and Montana. Its presence 


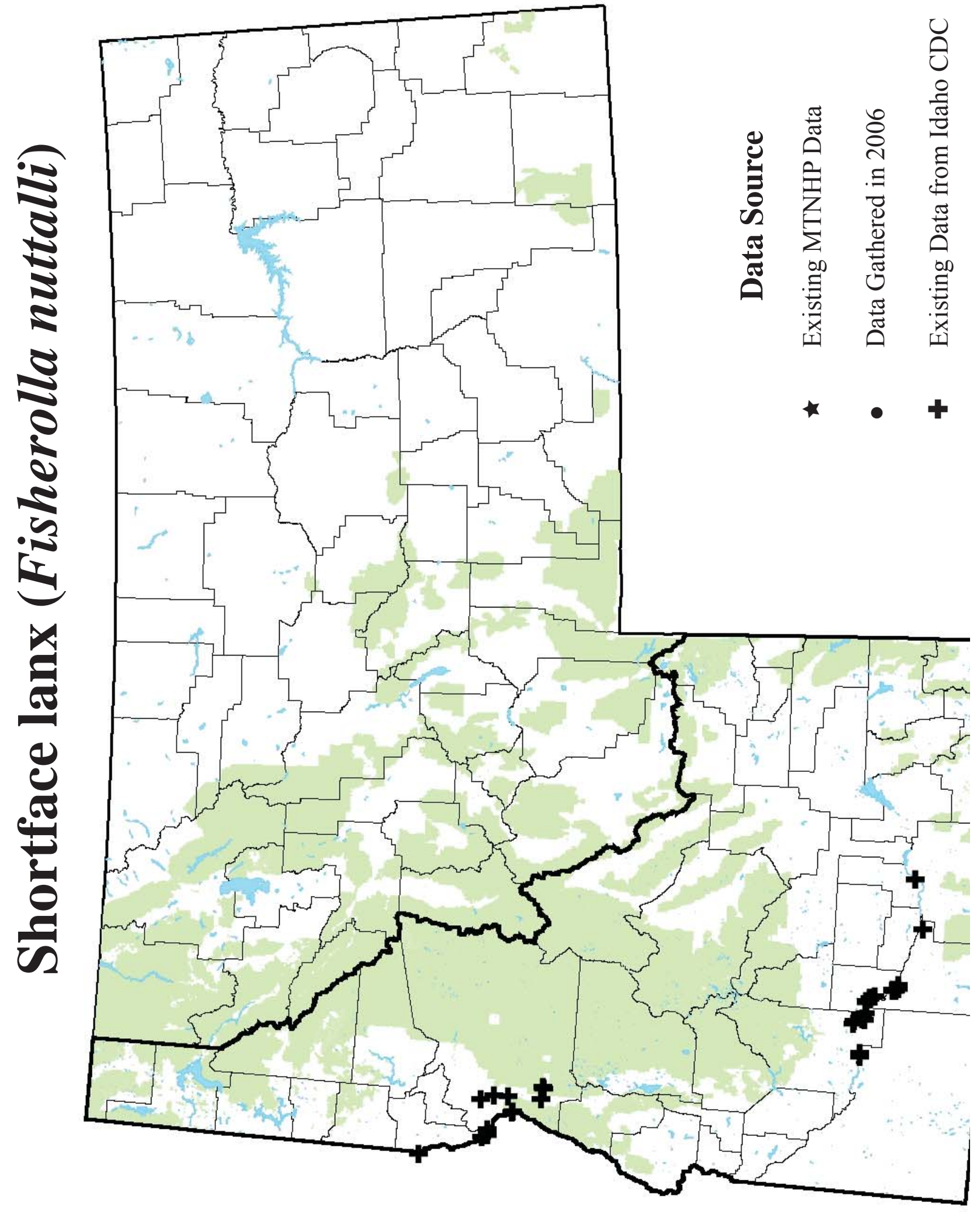


in the Columbia River drainage in British Columbia is assumed from the discovery of a shell (Clarke 1981). Occurrences are still reported in the Okanagan River drainage in British Columbia and confirmed in the Deschutes River of Oregon (Neitzel and Frest 1990), and Snake River of Idhao.

In Idaho the species occurs in the Middle and Upper Snake River reaches from Elmore County upstream to at least Bingham County (Idaho Conservation Data Center 2006). Populations also occur in the Salmon River and Hell's Canyon of the Snake River including parts of Nez Perce and Idaho counties. Populations within Idaho persist in parts of the Salmon and Snake rivers (Frest 1999). Although F. nuttalli is a species of concern, it appears to be doing well in the Snake River in Hells Canyon (Richards et al. 2005). In Montana, reported from the Clark Fork basin, but these old sites may be extirpated.

\section{Species Abundance}

The abundance of F. nuttalli in the Snake R. (Hell's Canyon Section) was 1-2 individuals per $\mathrm{m}^{2}$ (Richards et al. 2005). Generally it is not the most abundant member of the invertebrate community when habitat is suitable. Anecdotal evidence has indicated this species presence in Montana, but does not indicate abundance.

\section{Current Status}

\section{A. Why Species is of Conservation Concern}

Fisherola nuttalli is sporadically distributed at present in the Columbia (formerly widespread) and a few major tributaries in four states and possibly one province. Populations have been lost from most tributaries and almost all the Columbia River itself. It may be extirpated in British Columbia and Montana. It has no USFWS status at the present time, but was a candidate for the USFWS Threatened Species status in 1995, recommended by Frest and Johannes. It is currently a US Forest Service Species of Concern (SOC) (G2) and listed imperiled (S1) in ID and recently changed from imperiled (S1S2) to presumed extirpated Montana.

\section{B. Threats}

Specific threats to populations of Fisherola nuttalli have been identified as loss of habitat through impoundments, degraded water quality and siltation of cobbles, as well as nutrient enrichment. Effluence from agriculture, industry, and urban and residential developments has reduced water quality in much of the known range (Frest 1999).

\section{Distribution Relative to Land Allocations}

Current USFS Northern Region managed lands containing occurrences of this freshwater limpet include the Snake River Canyon (Hell's Canyon Wilderness Recreational Area) which is bordered on the ID side by the Nez Pearce National Forest, and the Wallowa National Forest on the Oregon side. 
Heritage Rank: G1, ID: S1

Natural History

\section{A. Taxonomy}

Class: Gastropoda

Family: Lymnaeidae

Stagnicola idahoensis (Henderson, 1931)

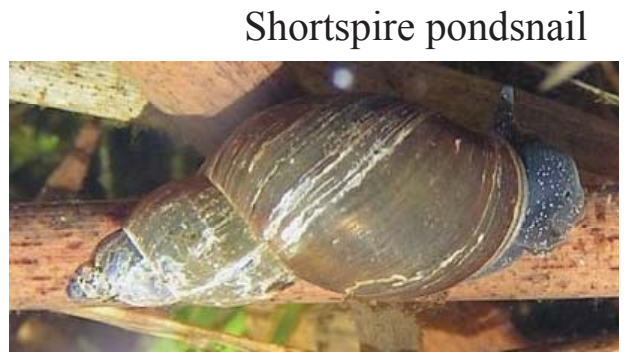

Generalized Stagnicola not idahoensis

Type Locality: Little Salmon River, 16 mi. N. of New Meadows.

Despite the long-standing recognition of this taxon as a distinct species, some authorities have raised uncertainty regarding its identity and validity. In particular, this taxon appears to be closely allied with the abbreviate pondsnail (Stagnicola apicina). Frest (1999) noted: "Taylor (1977, unpub.) and Taylor \& Bright (1987) regard only snails from a portion of the Little Salmon River as idahoensis, while treating those from the lower Little Salmon and from the Salmon itself as solida. We regard the lower Columbia apicina as distinct, following Burch (1989), and Salmon River occurrences of this species complex are disjunct and perhaps better regarded as idahoensis." R. Dillon (Northwest Biological Assessment Workgroup Gastropod Workshop, 2006) has suggested that both taxa (idahoensis and apicina) are synonyms of the woodland pondsnail ("Stagnicola" catascopium) which he places in the genus Lymnaea along with all other nominal members of the genus Stagnicola.

\section{B. Species Description}

The shell of this aquatic snail is dextrally spiraled and conical in general shape. The columella is lightly twisted, and the shell is brown; body is dark (see photo)(Frest 1999).

Reproductive Biology: This species is hermaphroditic. No information is available regarding the timing of reproduction or other aspects of reproductive ecology.

Ecology: This species occurs in cold water rivers in reaches with a moderately swift current and coarse, rocky substrates. Aquatic vegetation and algae are generally absent from occupied sites. This species is not found in areas with mud, sand, or bedrock (Frest 1999).

\section{Range and Known Sites}

This aquatic snail is endemic to the Little Salmon River and the lower Salmon River. Recent surveys by Frest (1999) failed to find this species in the lower Salmon River, the upper reaches of the Little Salmon River, and Hells Canyon. USGS biological data collected for water quality monitoring at Whitebird on the Salmon River reported 11 individuals collected during September 2000 . 


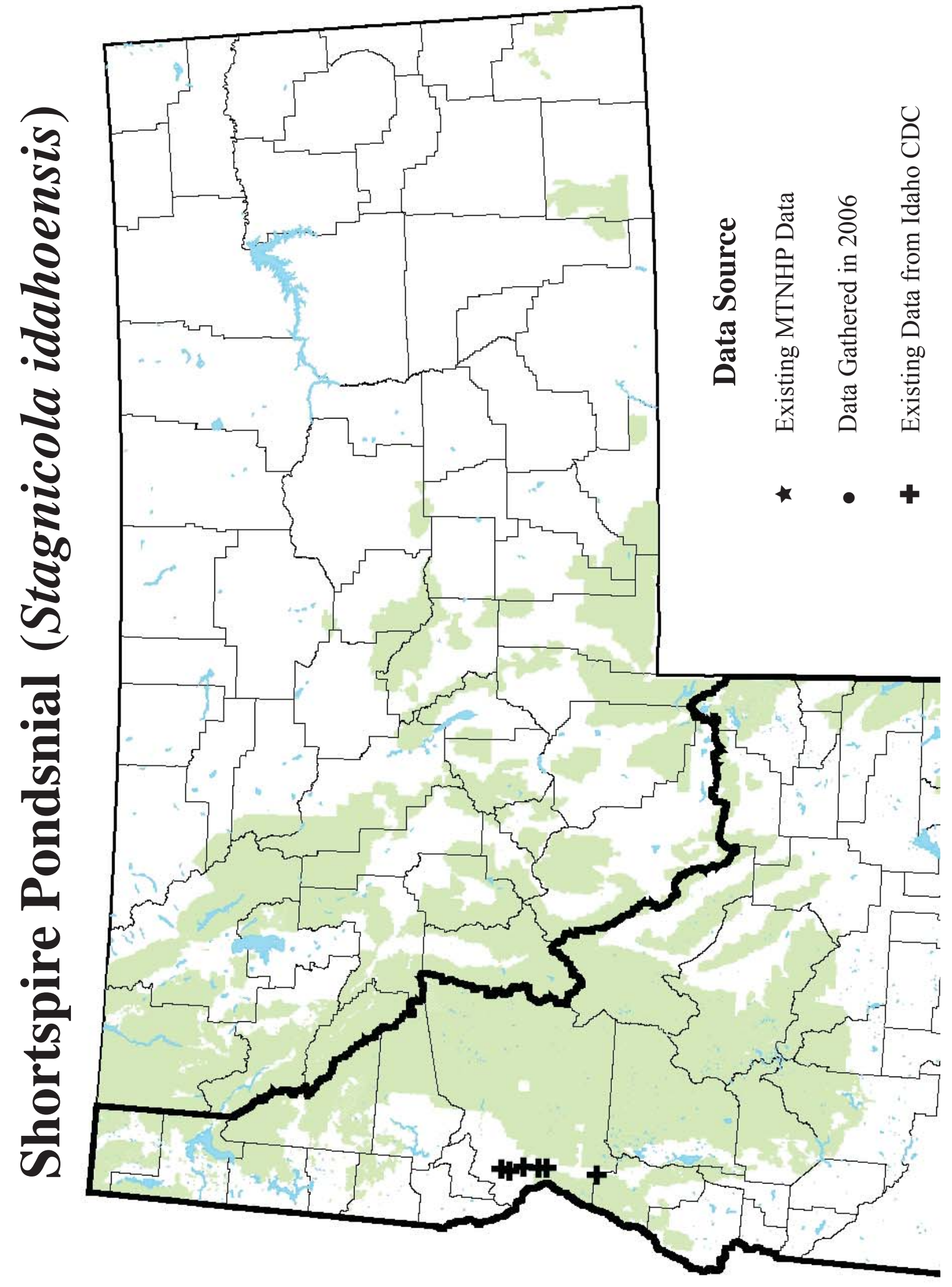




\section{Species Abundance}

The species is believed to have been lost from parts of the historical range. Data do not indicate whether the decline was historical or is ongoing, and current population status is not known.

\section{Current Status}

\section{A. Why Species is of Conservation Concern}

This species is limited in distribution. Surveys are needed to ascertain the current distribution and population numbers, considering that no extant populations were encountered during recent attempts to relocate the species.

\section{B. Threats}

Habitat loss is the primary threat to this species. Of particular concern are activities disturbing or altering the river bed and water quality. Road construction, mining, and gravel dredging have been identified as causes of habitat degradation (Frest 1999).

\section{Distribution Relative to Land Allocations}

Known locations are in the Little Salmon River and perhaps the mainstem of the Salmon River near Whitebird. These rivers are immediately adjacent to primarily privately owned lands. US Bureau of Land Management, Nez Perce National Forest (USFS Region 1), and Payette National Forest (USFS Region 4) lands are located along small portions of these rivers and along major tributaries. 
Heritage Rank: G1, MT: S1

Natural History

\section{A. Taxonomy}

Class: Gastropoda

Family: Lymnaeidae

Stagnicola elrodiana Baker 1935

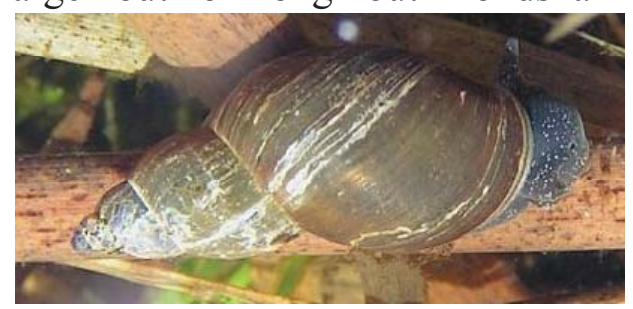

Generalized Stagnicola not elrodiana

\section{Type Locality: Lake McDonald, Lake Co., MT}

Despite the recognition of this taxon as a distinct species, some authorities have raised uncertainty regarding its identity and validity. R. Dillon (Northwest Biological Assessment Workgroup Gastropod Workshop, 2006) has suggested that multiple existing taxa (elrodi and elrodiana) are synonyms of the pondsnail ("Stagnicola" emarginata), which he places in the genus Lymnaea along with all other nominal members of the genus Stagnicola. Regarding elrodi and elrodiana - Hubendick (1951) considered both nomina to be synonyms of Lymnaea emarginata. Burch (1989) puts elrodi in the emarginata group and elrodiana in the elodes group. The range in variation in shell morphology of species of Stagnicola is tremendous, and basing different species on this character will lead to problems (Dillon pers comm. 2006), although he has not specifically published accounts synonomizing these species. "In any case, it's hard to find evidence in any of this that populations of either elrodi or elrodiana comprise valid biological species."

\section{B. Species Description}

The shell of this aquatic snail is dextrally spiraled and globose-conical in general shape. The columella is lightly twisted, and the shell is brown; body is dark (see photo) (Frest 1999).

Reproductive Biology: This species is hermaphroditic. No information is available regarding the timing of reproduction or other aspects of reproductive ecology.

Ecology: This species occurs in coldwater alpine-type lakes on cobbles. This species is not found in areas with mud, and large amounts of vegetation (Frest 1999). Most Lymnaeidae snails are scrapers of algae and other plant materials.

\section{Range and Known Sites}

Rangewide, Stagnicola elrodiana is only known to occur in Montana (NatureServe 2006). In Montana, old records exist for multiple lakes within the Flathead (Lakes Sin-yale-a-min and McDonald Lakes) and Whitefish Lake basins; additionally an old record exists from Stoney Lake in the Beaverhead-Deerlodge Forest (See distribution map). No new site records have been added in recent years, but surveys have been limited. 


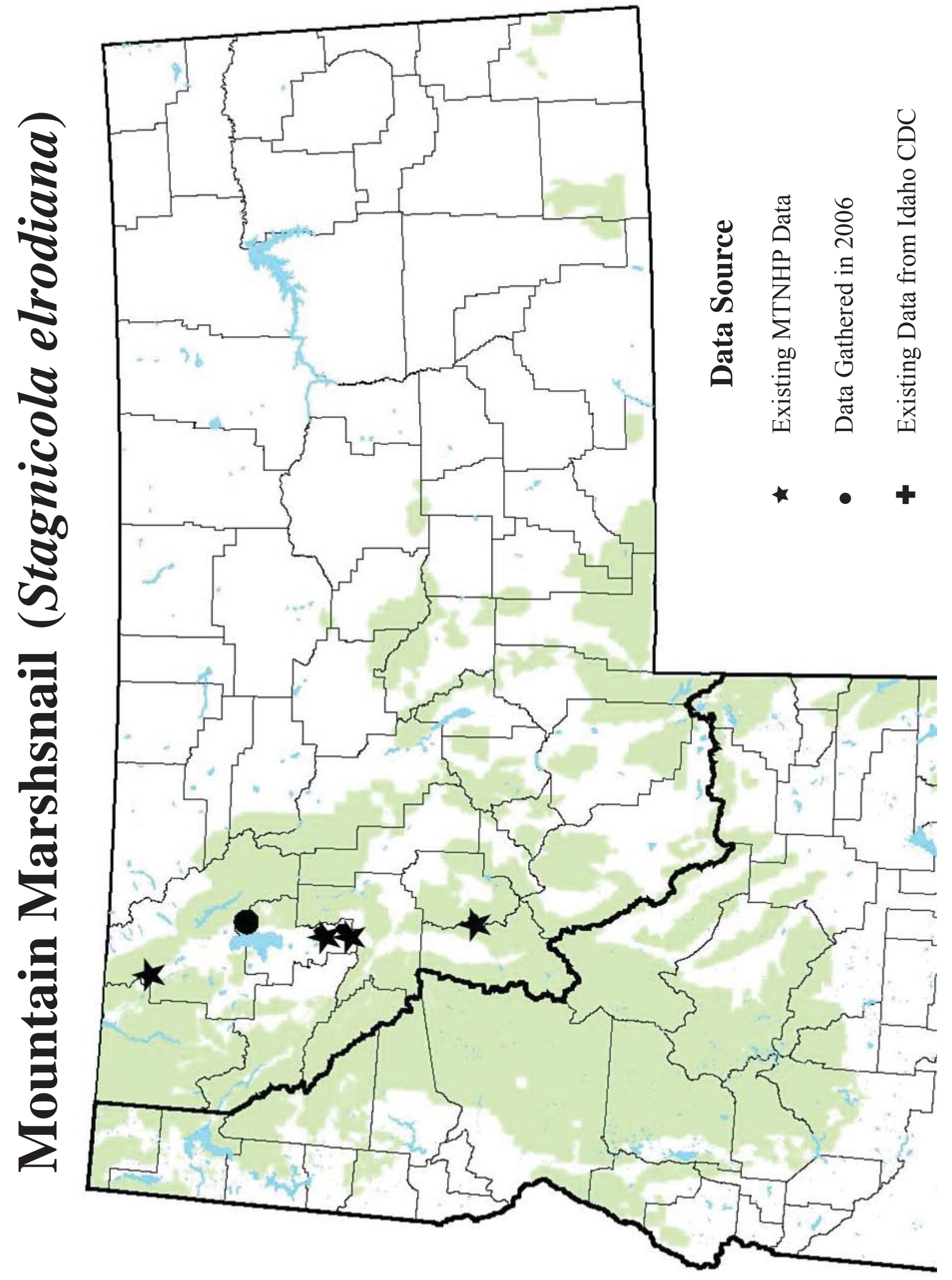




\section{Species Abundance}

Data do not indicate whether there is a decline in populations and current population status is not very well known.

\section{Current Status}

\section{A. Why Species is of Conservation Concern}

This "species" is limited in distribution, 4 lakes in Montana are its only known range. If it is a valid species it would be quite rare. Surveys are needed to ascertain the current distribution and population numbers, and DNA analysis should be done for taxonomic certainty of this species.

\section{B. Threats}

No known threats to these populations. Habitats in higher elevation alpine lakes offer some protection.

\section{Distribution Relative to Land Allocations}

Known locations within the high lakes of Flathead Lake basin border the Mission Mountain Tribal Wilderness Area which is managed by the Confederated Salish and Kootenai Tribes (CSKT). Thus, there is no immediate USFS Region 1 managed lands that would affect these populations, but significant portions of USFS managed lands are surrounding the Whitefish area lake and Stoney Lake (Flathead and Beaverhead-Deerlodge Forests) populations. 
Heritage Rank: G3, ID: SNR, MT: S2

\section{Natural History}

\section{A. Taxonomy}

Class: Gastropoda

Family: Lymnaeidae

Stagnicola montanensis (Baker 1913)

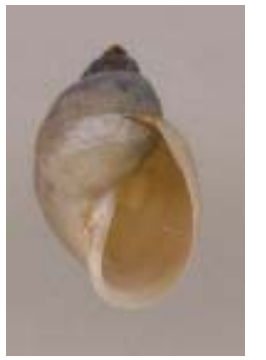

Photo of Stagnicola montanensis

Despite the long-standing recognition of this taxon as a distinct species, some authorities have raised uncertainty regarding its identity and validity. R. Dillon (Northwest Biological Assessment Workgroup Gastropod Workshop, 2006) has suggested that multiple existing taxa (montanaensis, idahoensis and apicina) are synonyms of the woodland pondsnail ("Stagnicola" catascopium) which he places in the genus Lymnaea along with all other nominal members of the genus Stagnicola. This species is extremely difficult to distinguish from some related species, especially Stagnicola caperata, with which it is sympatric in Utah.

\section{B. Species Description}

The shell of this aquatic snail is dextrally spiraled and globose-conical in general shape. The columella is lightly twisted, and the shell is brown; body is dark (see photo)(Frest 1999).

Reproductive Biology: This species is hermaphroditic. No information is available regarding the timing of reproduction or other aspects of reproductive ecology.

Ecology: This species occurs in small coldwater rivers or spring-fed tributaries to larger river systems. Aquatic vegetation and algae are generally absent from occupied sites. This species is not found in areas with mud, sand, or bedrock (Frest 1999). Since "[i]t is a pure-water snail", any degradation of water quality where it occurs, such as erosional runoff from road or other construction producing turbidity or siltation, would be a threat since "it is never found in ... muddy water bodies" (Taylor et al. 1963). Most Lymnaeidae snails are scrapers of algae and other plant materials.

\section{Range and Known Sites}

Rangewide, Stagnicola montanensis is known to occur in Montana, Idaho, Nevada, Utah, Wyoming and in the Canadian Province of Alberta (Taylor, Walter and Burch 1963, NatureServe 2006).This relatively broad but sporadic distribution reported by Taylor, Walter and Burch (1963) seems accurate. In Idaho multiple collection records exist for the Teton and Bear River drainages and from spring-fed tributaries to the Shoshone River in far southern ID. In Montana, old records exist for the Bitterroot and Clark Fork Drainages (See distribution map). Few new site records have been added in recent years. 


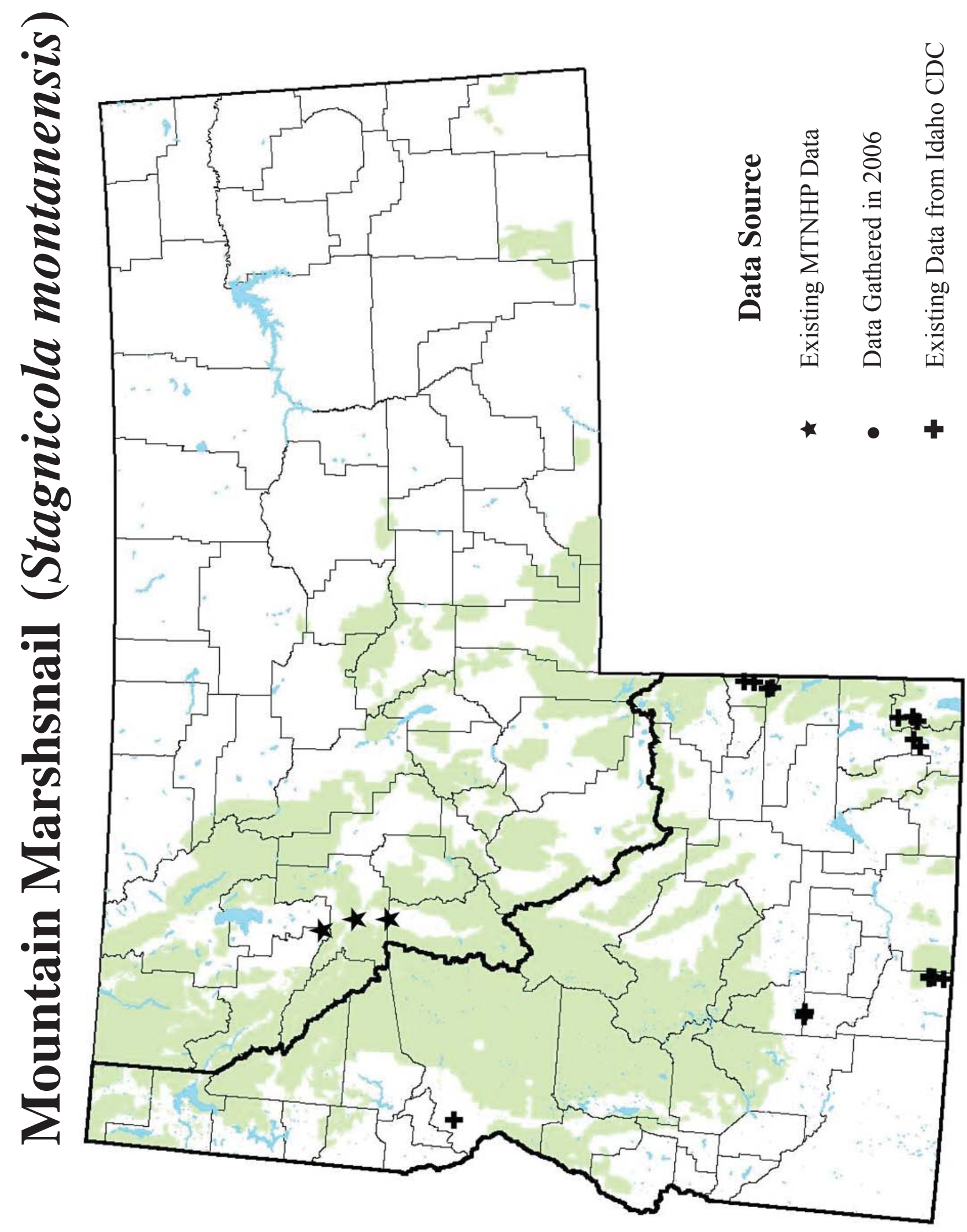




\section{Species Abundance}

The species is believed to have been lost from parts of the historical range. Data do not indicate whether the decline was historical or is ongoing, and current population status is not known.

\section{Current Status}

\section{A. Why Species is of Conservation Concern}

This species is limited in distribution, most states within the range do not have comprehensive distribution or survey information. This species is believed to be extirpated from Utah Little Bear River drainage. Surveys are needed to ascertain the current distribution and population numbers, and DNA analysis should be done for taxonomic certainty of this species.

\section{B. Threats}

Habitat loss is the primary threat to this species. Conversion of cold springs for stock and domestic usage and grazing are among the greatest threats (Frest 1999). Since "[i]t is a pure-water snail" (Taylor et al. 1963), any degradation of water quality where it occurs, such as erosional runoff from road or other construction producing turbidity or siltation, would be a threat since "it is never found in ... muddy water bodies" (Taylor et al. 1963).

\section{Distribution Relative to Land Allocations}

Known locations within the Bear, Bitterroot, Clark Fork, Shoshone and Teton River systems are mostly on privately owned river reaches. These rivers are immediately adjacent to primarily privately owned lands. US Bureau of Land Management, Nez Perce National Forest (USFS Region 1), and Payette National Forest (USFS Region 4) lands are located along small portions of these rivers and along major tributaries. 


\section{Conclusions and Recommendations}

The large number of new locations and previously undocumented records of aquatic invertebrate species of concern compiled from existing reports, and discovered through limited field surveys in 2006 (mostly within MT Lolo and BeaverheadDeerlodge Forests of the USFS Northern Region) underscores the paucity of current knowledge concerning the distribution, ecology, and conservation status of most invertebrate species. We can confidently report that permanently flowing headwater $\left(1^{\text {st }}\right.$ or $2^{\text {nd }}$ order $)$ non-fish bearing streams (Category 2, USFS 2006) contain a higher proportion of the aquatic species of conservation concern than some of the larger stream systems. Initial conclusions regarding the stream type and habitat associations of many of these Rocky Mountain Refugium taxa enables us to recommend that Riparian Conservation Areas (RCA's) be strictly enforced for all Category 2 streams in the Lolo-Bitterroot-Clearwater Forests straddling the Idaho/Montana border. Proper management of these stream types will not only benefit these species, but also species inhabiting reaches further down in the watershed.

We believe at least 2-3 additional years of targeted habitat surveys, similar to those of 2006, is needed to fill distribution gaps and gather additional site specific habitat and ecological information on the aquatic invertebrate SOC. Subsequently, a year of randomized site surveys following predictive model development are needed to ground truth the model and refine habitat association to fully delineate robust species distributions. Overall, the goal of this study is to provide biologists and land managers some of the tools they need to make informed management decisions in areas likely to contain these species of conservation concern. Conservation Recommendations:

* Identify and map extant viable populations of the SOC species at the watershed-scale within USFS lands and ensure the protection of the habitat types for these species.

* Protect critical high diversity watersheds (e.g. headwater NRMR areas) from future road development and habitat degradation by following best management practices, protecting riparian areas (RCA's) and potentially setting up additional Research Natural Areas (RNA's).

* Promote land stewardship practices through educational programs and encourage responsible forest management planning. 


\section{Literature Cited}

Addis, J. S. \& K. J Peterson. 2005. Phylogenetic relationships of freshwater sponges (Porifera, Spongillina) inferred from analyses of $18 \mathrm{~S}$ rDNA, COI mtDNA, and ITS2 rDNA sequences. Zoologica Scripta 34 (9), 549-557.

Allen, R.K 1984. A new classification of the subfamily Ephemerellinae and the description of a new genus. Pan-Pacific Entomologist 60, 245-247.

Allen, R. K. and G. F. Edmunds, Jr. 1961. A revision of the genus Ephemerella (Ephemeroptera: Ephemerellidae) II. The subgenus Caudatella. Ann. Entomol. Soc. Am. 54: 603-612.

Allen, R. K. and G. F. Edmunds. 1959. A revision of the genus Ephemerella (Ephemeroptera: Ephemerellidae). Canadian Entomologist 91: 51-58.

Anderson, N.H. 1976. The distribution and biology of the Oregon Trichoptera. Oregon Agricultural Experiment Station Technical Bulletin, 134:1152.

Barbour, M., J. Gerritsen, B.D. Snyder and J. B. Stribling. 1999. Rapid Bioassessment Protocols for Use in Streams and Wadable Rivers: Periphyton, Benthic Macroinvertebrates and Fish, Second Edition. EPA 841-B-99-002. United States Environmental Protection Agency; Office of Water: Washington, D.C.

Baumann, Richard. 2007. Brigham Young University, Provo, UT.

Baumann, R. W., A. R. Gaufin, and R. F. Surdick. 1977. The stoneflies (Plecoptera) of the Rocky Mountains. Memoirs of the American Entomological Society 31: $207 \mathrm{p}$.

Baumann, R. W. 1973. Studies on Utah stoneflies (Plecoptera). Great Basin Naturalist 33(2): 91108.
Baumann, R. W., and A. R. Gaufin. 1971. New species of Nemoura from western North America. Pan-Pacific Entomologist 47: 270-278.

Barton, S.H. and J.S. Addis. (1997). Freshwater sponges (Porifera: Spongillidae) of western Montana. Great Basin Naturalist 57:22, 93-103.

Beer, Frank M. 1971. Note on Cicindela columbica Hatch. Cicindela 3(2): 32.

Brunsfeld S. J., J. Sullivan, D. E. Soltis and P. S. Soltis. 2001. Comparative phylogeography of northwestern North America: A synthesis. Pages 319-339 in Integrating Ecology and Evolution in a Spatial Context. (J. Silvertown, J. Antonovics, eds.). Blackwell Publishing, Williston, VT

Brunson, R. B. 1967. Zoogeography of Mollusca of western Montana [abstract]. Annual Reports, American Malacological Union 33: 43.

Burch, J. B. 1989. North American Freshwater Snails. Malacological Publications, Hamburg, Michigan. 365 pp.

Clarke, A.H. 1981. The Freshwater Molluscs of Canada. National Museum of Natural Sciences, National Museums of Canada, Ottawa, Ontario. $446 \mathrm{pp}$.

Denning, D. G. 1948. New and little known species of Nearctic Trichoptera. Psyche, 55: 16-27.

Denning, D. G. 1949. New species of nearctic caddisflies. Bulletin of the Brooklyn Entomological Society 44:37-48.

Denning, D.G. 1950. New species of unusual western Trichoptera. Pan-Pacific Entomologist, $2634-50$.

Denning, D.G. 1956. Several new species of western Trichoptera. Pan-Pacific Entomologist, 32: 73-80. 
Denning, D. G. 1965. New Trichoptera from United States and Mexico. Pan-Pacific Entomologist, 41: 262-272.

Denning, D. G. 1968. New species and notes of western Trichoptera. Journal of the Kansas Entomological Society, 41: 63-69.

Denning, D. G. 1973. New species of Trichoptera. Pan-Pacific Entomologist, 51(4): 318-326.

Denning, D. G. 1975. New and unusual Rhyacophila (Trichoptera: Rhyacophilidae). Canadian Entomologist, 107: 953-962.

Dillon, R. 2006. Northwest Biological Assessment Workgroup Gastropod Workshop. Unpublished workshop materials.

Dillon, R. T. 2000. The Ecology of Freshwater Molluscs. Cambridge University Press, Cambridge. $509 \mathrm{pp}$.

Edmunds, G. F., Jr. 1957. On the life history of Parameletus columbiae McDunnough (Ephemeroptera). Utah Academy Proceedings 34: 25-26.

Edmunds, G. F., Jr., and C. M. Murvosh. 1995. Systematic changes in certain Ephemeroptera studied by R. K. Allen. Pan-Pacific Entomologist 71(3):157-160.

Fend, S.V. and D.L.Gustafson 2001. A new lumbriculid genus and species from North America (Clitellata, Lumbriculidae). Hydrobiologia 463, No.1-3: 13-22.

Frest, T. J., and E. J. Johannes. 2001. An annotated checklist of Idaho land and freshwater mollusks. Journal of the Idaho Academy of Science $36: 1-51$.

Frest, T. J. 1999. A review of the land and freshwater mollusks of Idaho. Final report prepared for Idaho Conservation Data Center, Idaho Department of Fish and Game, Boise, Idaho. 281 p. + appendices.
Frest, T. J., and E. J. Johannes. 1997. Land snail survey of the lower Salmon River drainage, Idaho. Idaho Bureau of Land Management Technical Bulletin 97-18. 142 p. + appendices.

Frest, T. J. and E. J. Johannes. 1995. Interior Columbia Basin mollusk species of special concern. Final report to the Interior Columbia Basin Ecosystem Management Project, Walla Walla, WA. Contract \#43-0E00-4-9112. 274 pp. plus appendices.

Freitag, R. P. 1999. Catalogue of the tiger beetles of Canada and the United States. National Research Council Research Press, Ottawa, Canada. $195 \mathrm{pp}$.

Frison, T. H. 1942. Descriptions, records and systematic notes concerning western North American stoneflies (Plecoptera). Pan-Pacific Entomologist 18(1): 9-16.

Giersch, J.J. 2002. Revision and Phylogenetic Analysis of the Verrula and Alberta Species Groups of Rhyacophila Pictet 1834 with Description of A New Species (Trichoptera: Rhyacophilidae). Montana State University. Unpublished Thesis. 221pp.

Gangloff, M.M. and D.L. Gustafson. 2000. Freshwater mussels (Bivalvia: Unionoida) of Montana. Central Plains Archaeology, 8(1): 121130.

Gustafson, D.G. 2007. Aquatic Invertebrates of Montana (AIM). Online Web Site. http://www. esg.montana.edu/dlg/aim/trichop/trichop0.html (Accessed: April 17, 2007).

Gustafson, D.R. 2001. Westslope Cutthroat Hypothesis. Presentation to the American Fisheries Society Meeting, Bozeman, MT.

Hannibal, H. 1912. A Synopsis of the Recent and Tertiary Freshwater Mollusca of the Californian Province, based upon an Ontogenetic Classification. Proceedings of the Malacological Society of London 10: 112-166. 
Hanson, J. R. 1943. Descriptions of new North American Plecoptera. II. Proceedings of the Entomological Society of Washington 45: 8588.

Hatch, M. H. 1938. Two new species of Helmidae from a Warm Spring in Montana. (Coleoptera). Entomol. News 49:16-19

Hawkins, C.P. 1984. Substrate Associations and Longitudinal Distributions in Species of Ephemerellidae (Ephemeroptera:Insecta) from Western Oregon. Freshwater Invertebrate Biology, Vol. 3: No. 4, pp. 181-188

Hendricks, Paul. 2003. Status and Conservation Management of Terrestrial Mollusks of Special Concern in Montana. Report to Region I, U.S. Forest Service. Montana Natural Heritage Program, Helena. 67 pp. + appendicies. Available: http://nhp.nris.state.mt.us/animal/reports/inverts/Montana_Mollusk_Report.pdf

Hershler, R. 1999. A systematic review of the hydrobiid snails (Gastropoda: Rissooidea) of the Great Basin, western United States. Part II. Genera Colligyrus, Eremopyrgus, Fluminicola, Pristinicola, and Tryonia. Veliger 42:306-337.

Hershler, R., T. Frest, E. Johannes, P. Bowler, and F. Thompson. 1994. Two new genera of hydrobiid snails (Prosobranchia: Rissooidea) from the northwestern United States. Veliger 37: 221243.

Hooten, M. M. 1991. Biological systematics of Zaitzevia thermae (Hatch). Masters thesis, Montana State University. 88 pp.

Hubendick, B. 1951. Recent Lymnaeidae. Their variation, morphology, taxonomy, nomenclature, and distribution. Kungl Svenska Vetenskapasakademiens Handlingar 3: 1-223.

Hyman, L.H., 1967. The invertebrates Mollusca I (vol. VI). McGraw-Hill,. New York. 288pp.
Idaho Department of Environmental Quality. 2007. Beneficial Use Reconnaisance Program. Available at: http://www.deq.state.id.us/water/data reports/surface water/monitoring/ overview. cfm\#beneficial

Idaho Comprehensive Wildlife Conservation Strategy. 2006. Available at: http://fishandgame.idaho.gov/cms/tech/CDC/cwcs pdf/ appendix\%20b.pdfIdaho Department of Environmental Quality. 2005. 1410 North Hilton, Boise, ID 83706.

Idaho Department of Environmental Quality. 2002a. The Idaho Department of Environmental Quality Water Body Assessment Guidance, Second Edition-Final. Idaho Department of Environmental Quality; Boise, Idaho. http://www. deq.state.id.us/water/data_reports/surface_water/monitoring/wbag_02_entire.pdf

IdahoDEQ. 2002b. Macroinvertebrate Temperature Tolerances. http://www.deq.state.id.us/water/ data reports/surface water/monitoring/wbag 02 part2.pdf

Jacobus, L. M. and W. P. McCafferty. 2004. Contribution to the morphology and descriptive biology of Caurinella idahoensis (Ephemeroptera: Ephemerellidae). Western North American Naturalist 64: 101-108.

Jensen, S. L. 1966. The mayflies of Idaho (Ephemeroptera). Unpublished Master of Science Thesis, University of Utah, Salt Lake City. $367 \mathrm{pp}$.

Jewett, S. G., Jr. 1954. New stoneflies (Plecoptera) from western North America. Journal of the Fisheries Research Board of Canada 11: 543-549.

Johnston F.D. \& R. Steele 1978. New plant records for the Idaho Pacific Coastal Refugia. Northwest Science 52: 205-211. 
Kondratieff, B. C. (coordinator). 2000. Mayflies of the United States. Jamestown, ND: Northern Prairie Wildlife Research Center Online. http:// www.npwrc.usgs.gov/resource/distr/insects/ mfly/mflyusa.htm (Version 12DEC2003).

LaBonte, J. R. 1995. Possible threatened or endangered terrestrial predaceous Coleoptera of the Columbia River Basin. Prepared for the BLM/USFS Eastside Ecosystem Management Project. Corvallis, OR. 31 pp.

Lazorchak, J.M., Klemm, D.J., and D.V. Peck (editors). 1998. Environmental Monitoring and Assessment Program - Surface Waters: Field Operations and Methods for Measuring the Ecological Condition of Wadeable Streams. EPA/620/R-94/004F. U.S. Environmental Protection Agency, Washington, D.C.

Leonard, W.P., L. Chichester, J. Baugh, and T. Wilke. 2003. Kootenaia burkei, a new genus and species of slug from northern Idaho, United States (Gastropoda: Pulmonata: Arionidae). Zootaxa 355:1-16.

Lester, G. 2007. EcoAnalysts, Inc., 105 East 2nd Street, Suite 1, Moscow, ID 83843.

Lester, G., W. P. McCafferty, and M. R. Edmondson. 2002. New mayfly (Ephemeroptera) records from Idaho. Entomological News 113(2): 131-136.

Logan, E. R., and S. D. Smith. 1966. New distributional records of intermountain stoneflies (Plecoptera). Occasional Papers of Biological Soc. of Nevada No. 9: 1-3.

Maketon, M., and K. W. Stewart. 1984. Drumming behavior in four North American Perlodidae (Plecoptera) species. Annals of the Entomological Society of America 77(5): 621-626.

McCafferty, W. P. 2001. Notes on distribution and orthography associated with some poorly known North American mayflies (Ephemeroptera). Entomological News 112(2): 121-122.
McCafferty, W.P. and B.C. Kondratieff. 1999. New species of Paraleptophlebia (Ephemeroptera: Leptophlebiidae) from Idaho and Washington. Entomological News 110(4): 217-220.

McDunnough, J. 1931. New species of North American Ephemeroptera. The Canadian Entomologist 63: 82-93.

McDunnough, J. 1934. New species of North American Ephemeroptera IV. The Canadian Entomologist 66: 154-164, 181-188.

McDunnough, J. 1936. Further notes on the genus Ameletus with descriptions of new species (Ephemeroptera). The Canadian Entomologist 68: 207-211.

Merritt, R. W. and K. W. Cummins. 1996. An introduction to the aquatic insects of North America. $3^{\text {rd }}$ Edition. Kendall/Hunt Publishing Company, Dubuque, IA. 862 pp.

Montana DEQ. 2005. Sample Collection, Sorting, and Taxonomic Identification of Benthic Macroinvertebrates. Montana Department of Environmental Quality Water Quality Planning Bureau Standard Operating Procedure WQPBWQM009. April 2005.

Montana Natural Heritage Program (2006). Animal Field Guide. Natural Heritage Program and Montana Fish, Wildlife \& Parks. Available: http://nhp.nris.state.mt.us/animalguide/

NatureServe. 2006. NatureServe Explorer: An online encyclopedia of life [web application]. Version 6.1. NatureServe, Arlington, Virginia. Available http://www.natureserve.org/explorer. (Accessed: March 29, 2007 ).

Neitzel, D.A. and T.J. Frest. 1989. Survey of Columbia River Basin streams for giant Columbia River spire snail Flumincola columbiana and great Columbia River limpet Fisherola nuttalli. Tech. Rep. \#PNL7103, Battelle Pacific Northwest Labs. 59 pp. 
Neitzel, D.A., and T.J. Frest. 1990. Survey of Columbia River Basin Streams for Columbia Pebblesnail and Shortface Lanx, Fisheries. 15(2):2-3.

Nelson, C. Riley. 1996. Nemouridae. Version 01 January 1996 (under construction). http://tolweb.org/Nemouridae/13941/1996.01.01 in The Tree of Life Web Project

Nelson, C. R., and R. W. Baumann. 1989. Systematics and distribution of the winter stonefly genus Capnia (Plecoptera: Capniidae) in North America. Great Basin Naturalist 49(3): 289363.

Newell, R.L. and G.W. Minshall. 1977. An annotated list of the aquatic insects of southeastern Idaho, Part II: Trichoptera. Great Basin Naturalist 37: 253-257.

Newall, R. L., and G. W. Minshall. 1978. An annotated list of the aquatic insects of southeastern Idaho. Part III. Ephemeroptera. Great Basin Naturalist 38(1): 55-58.

Newell, R.L. and D.S. Potter. 1973. Distribution of some Montana caddisflies. Proceedings of the Montana Academy of Sciences 33: 12-21.

Nimmo, A.P. and G.G.E. Scudder. 1978. An annotated checklist of the Trichoptcra (Insecta) of British Columbia. SYESIS 11: 117-134.

Nimmo, A.P. 1971. The adult Rhyacophilidae and Limnephilidae (Trichoptera) of Alberta and eastern British Columbia and their post-glacial origin. Quaestiones Entomologicae Vol 7: 1232.

Oliver, G.V. and W.R. Bosworth, III. 1999. Rare, imperiled, and recently extinct or extirpated mollusks of Utah. Report to the Utah Division of Wildlife Resources, Publication Number 9929, Salt Lake City, Utah. 231 pp.

Paul, A. J. and H. F. Clifford. 1991. Acroloxus coloradensis (Henderson), a Rare North American Freshwater Limpet. The Nautilus 105: 173-1 74.
Peterson, K.J., and J.S. Addis. 2000. Clypeatula cooperensis gen. n., sp. n., a freshwater spong (Porifera, Spongilidae) from the Rocky Mountains of Montana, USA. Zoologica Scripta 29: 265-274.

Richards, D.C., M. Falter, G.T. Lester 2005. Additional Information Request Ar-2--Listed Mollusks. Report to the Idaho Power Company. Hells Canyon Project FERC No. P-1971-079

Ricker, W.E. 1952. Systematic Studies in Plecoptera. Indiana University Pub. Sci. Ser. 18, 200pp.

Roemhild, G. 1982. The Trichoptera of Montana with distributional and ecological notes. Northwest Science 56(1): 8-1.3.

Ross, H.H. 1956. Evolution and classification of the mountain caddisflies. The University of Illinois Press, Urbana, IL. 213 pp.

Rumpp, N. L. 1967. A new species of Cicindela from Idaho (Coleoptera: Cicindelidae). Proceedings of the California Academy of Sciences 35(7): 129-140.

Scudder,G.E. 1994. An annotated systematic list of the potentially rare and endangered freshwater and terrestrial invertebrates in British Columbia. Occ. Pap. 2, Entomol. Soc. B.C. 92pp.

Schmid, F. 1970. Le genre Rhyacophila et la famille des Ryacophilidae (Trichoptera). Mem. de la Societe Entomologique du Canada. No. 66

Shook, G. 1981. The status of the Columbia River tiger beetle (Cicindela columbica Hatch) in Idaho (Coleoptera: Cicindelidae). Pan-Pacific Entomologist 57(2): 359-363.

Smith, S.D. 1968. The Rhyacophila of the Salmon River drainage of Idaho with special reference to larvae. Annals Entomol. Sot. Amer. 61(3): 655-674. 
Stanger, J. A., and R. W. Baumann. 1993. A revision of the stonefly genus Taenionema (Plecoptera: Taeniopterygidae). Transactions of the American Entomological Society 119(3): 171-229.

Stark, B.P. and B.C. Kondratieff. 2004. Pictetiella lechleitneri (Plecoptera: Perlodidae), a new species from Mount Rainier National Park, Washington, U.S.A. Proceedings of the Entomological Society of Washington 106(4): 747-750.

Stark, B.P.and DL Gustafson 2004. New species and records of Soliperla Ricker, 1952 from western North America (Insecta, Plecoptera). Spixiana.27(2): 97-105. Zoologische Staatssammlung Muenchen

Szczytko, S. W., and K. W. Stewart. 1979. The genus Isoperla (Plectoptera) of western North America; holomorphology and systematics, and a new stonefly genus Cascadoperla. Memoirs of the American Entomological Society Number 32. $120 \mathrm{pp}$.

Taylor, D.W. 1982. Status Report on Giant Columbia River Limpet in Southwestern Idaho. Tomales Bay Marine Laboratory, Marshall, Ca. $10 \mathrm{pp}$.

Taylor, D. W., H. J. Walter, and J. B. Burch. 1963. Freshwater snails of the subgenus Hinkleyia (Lymnaeidae: Stagnicola) from the western United States. Malacologia 1: 237-281.

Traver, J. R. 1935. Part II. North American mayflies: a systematic account of North American species in both adult and nymphal stages. Page 528 in J. G. Needham, J. R. Traver, and Y. -C. Hsu (eds.), The biology of mayflies. Comstock, Ithaca, NY.
Turgeon, D.D., J.F. Quinn, Jr., A.E. Bogan, E.V. Coan, F.G. Hochberg, W.G. Lyons, P.M. Mikkelsen, R.J. Neves, C.F.E. Roper, G. Rosenberg, B. Roth, A. Scheltema, F.G. Thompson, M. Vecchione, and J.D. Williams. 1998. Common and scientific names of aquatic invertebrates from the United States \& Canada: Mollusks. 2nd Ed. AFS Special Pub 26, Bethesda, MD: 526 pp.

USDI Fish and Wildlife Service. 2006.

Threatened, Endangered and Candidate Species for the Bitterroot National Forest.

Threatened, Endangered and Candidate Species for the Flathead National Forest.

Threatened, Endangered and Candidate Species for the Lolo National Forest.

Web: http://montanafieldoffice.fws.gov/Endangered Species/Listed Species/Forests.html

USFS Northern Region. 2006. http://www.fs.fed. us/r1/wmpz/documents/proposed-plans-psd/lnf/ documents/wl-spp-tbl-explan041306.pdf

U.S. Fish and Wildlife Service. 2006. Conservation Agreement and Strategy for the thermie Riffle Beetle, Zaitzevia Thermae And Brown's Riffle Beetle, Microcylloepus browni at the Bozeman Fish Technology Center, Bozeman, Montana. 20pp.

U.S. Fish and Wildlife Service. 1996. Endangered and Threatened Wildlife and Plants; Review of Plant and Animal Taxa That Are Candidates for Listing as Endangered or Threatened Species. Federal Register 61(40):7596-7613.

U. S. Fish and Wildlife Service. 1988. Endangered and threatened wildlife and plants; findings on pending petitions and descriptions of progress on listing actions. Notice of Petition Findings. Federal Register 53(250): 52746-52749.

US Geological Survey. 2006. Salmon River Basin Water Quality Records. Idaho Surface Water Quality Statewide Network. Data accessed May 2007 at http://id.water.usgs.gov/public/wq/ stations.html 
van Soest, R., N. Boury-Esnault, D. Janussen and J. Wiggins G. B.; Weaver J. S., and Unzicker J. D. Hooper 2005. World Porifera database. Available online at http://www.vliz.be/vmdcdata/porifera Consulted on 2007-05-04 1985. Revision of the caddisfly family Uenoidae (Trichoptera). Canadian Entomologist Vol. 117 , no. 6, pp. 763-800.

Vannote,R.L. and G. W. Minshall. 1982. Fluvial Processes and Local Lithology Controlling Abundance, Structure and Composition of Mussel Beds. PNAS 79: 4103-4107

Waters, T.F. 1995. Sediment in streams. American Fisheries Society Monograph 7, American Fisheries Society, Bethesda, MD

Wiggins, G.B. 1965. Additions and revisions to the genera of North American caddisflies of the family Brachycentridae with special reference to the larval stages (Trichoptera). Canad. Entomol. 97: 1089-1106.

Wiggins, G.B. 1996. Larvae of the North American caddisfly genera (Trichoptera). University of Toronto Press, Toronto, Ontario. $2^{\text {nd }}$ Edition. $457 \mathrm{pp}$.

Woods, A.J. Omernick, J.M., J.A. Nessar. 2002.

Ecoregions of Montana. 2nd edition poster.

Zloty, J. 1996. A revision of the Nearctic Ameletus mayflies based on adult males, with descriptions of seven new species (Ephemeroptera: Ameletidae). The Canadian Entomologist 128: 293-346.

Zloty, J., and G. Pritchard. 1997. Larvae and adults of Ameletus mayflies (Ephemeroptera: Ameletidae) from Alberta. The Canadian Entomologist 129: 251-289. 

Appendix A. Global/State Rank Definitions 



\section{Heritage Program Ranks}

The international network of Natural Heritage Programs employs a standardized ranking system to denote global (range-wide) and state status. Species are assigned numeric ranks ranging from 1 to 5 , reflecting the relative degree to which they are "at-risk". Rank definitions are given below. A number of factors are considered in assigning ranks — the number, size and distribution of known "occurrences" or populations, population trends (if known), habitat sensitivity, and threat. Factors in a species' life history that make it especially vulnerable are also considered (e.g., dependence on a specific pollinator).

Global Rank Definitions (NatureServe 2003)

G1 Critically imperiled because of extreme rarity and/or other factors making it highly vulnerable to extinction

G2 Imperiled because of rarity and/or other factors making it vulnerable to extinction

G3 Vulnerable because of rarity or restricted range and/or other factors, even though it may be abundant at some of its locations

G4 Apparently secure, though it may be quite rare in parts of its range, especially at the periphery

G5 Demonstrably secure, though it may be quite rare in parts of its range, especially at the periphery

T1-5 Infraspecific Taxon (trinomial) - The status of infraspecific taxa (subspecies or varieties) are indicated by a “T-rank” following the species’ global rank

\section{State Rank Definitions}

S1

At high risk because of extremely limited and potentially declining numbers, extent and/or habitat, making it highly vulnerable to extirpation in the state

S2 At risk because of very limited and potentially declining numbers, extent and/or habitat, making it vulnerable to extirpation in the state

S3 Potentially at risk because of limited and potentially declining numbers, extent and/or habitat, even though it may be abundant in some areas

S4 Uncommon but not rare (although it may be rare in parts of its range), and usually widespread. Apparently not vulnerable in most of its range, but possibly cause for long-term concern Common, widespread, and abundant (although it may be rare in parts of its range). Not vulnerable in most of its range

\section{Combination RANKS}

G\#G\# or S\#S\# Range Rank-A numeric range rank (e.g., G2G3) used to indicate uncertainty about the exact status of a taxon

\section{QUALIFIERS}

NR

Q

\section{Not ranked}

Questionable taxonomy that may reduce conservation priority-Distinctiveness of this entity as a taxon at the current level is questionable; resolution of this uncertainty may result in change from a species to a subspecies or hybrid, or inclusion of this taxon in another taxon, with the resulting taxon having a lower-priority (numerically higher) conservation status rank 
X

H

U

HYB

?

C

A

Z

P

R

SYN

*

B

$\mathrm{N}$

Presumed Extinct-Species believed to be extinct throughout its range. Not located despite intensive searches of historical sites and other appropriate habitat, and virtually no likelihood that it will be rediscovered

Possibly Extinct-Species known from only historical occurrences, but may never-theless still be extant; further searching needed

Unrankable-Species currently unrankable due to lack of information or due to substantially conflicting information about status or trends

Hybrid — Entity not ranked because it represents an interspecific hybrid and not a species

Inexact Numeric Rank-Denotes inexact numeric rank

Captive or Cultivated Only_-Species at present is extant only in captivity or cultivation, or as a reintroduced population not yet established

Accidental-Species is accidental or casual in Montana, in other words, infrequent and outside usual range. Includes species (usually birds or butterflies) recorded once or only a few times at a location. A few of these species may have bred on the one or two occasions they were recorded

Zero Occurrences-Species is present but lacking practical conservation concern in Montana because there are no definable occurrences, although the taxon is native and appears regularly in Montana

Potential-Potential that species occurs in Montana but no extant or historic occurrences are accepted

Reported-Species reported in Montana but without a basis for either accepting or rejecting the report, or the report not yet reviewed locally. Some of these are very recent discoveries for which the program has not yet received first-hand information; others are old, obscure reports

Synonym - Species reported as occurring in Montana, but the Montana Natural Heritage Program does not recognize the taxon; therefore the species is not assigned a rank

A rank has been assigned and is under review. Contact the Montana Natural Heritage Program for assigned rank

Breeding-Rank refers to the breeding population of the species in Montana

Nonbreeding — Rank refers to the non-breeding population of the species in Montana

Appendix A - 2 
Appendix B. Aquatic Survey Sites with SOC Added to the USFS REGION 1 IN 2006 



\begin{tabular}{|c|c|c|c|c|c|}
\hline SOC Species & WaterbodyName & Latitude & Longitude & \begin{tabular}{|l|} 
Collection \\
Date
\end{tabular} & Agency \\
\hline Agapetus montanus & Bear Creek & 45.651 & -110.953 & $7 / 24 / 2003$ & DEQ \\
\hline Agapetus montanus & Beaver Creek & 46.755 & -111.310 & $7 / 20 / 2004$ & DEQ \\
\hline Agapetus montanus & Beaver Creek & 46.744 & -111.409 & $7 / 20 / 2004$ & DEQ \\
\hline Agapetus montanus & Beaver Creek & 46.799 & -111.844 & $8 / 8 / 2005$ & DEQ \\
\hline Agapetus montanus & Big Hole North Fork & 45.705 & -113.459 & $7 / 9 / 2003$ & DEQ \\
\hline Agapetus montanus & Big Hole North Fork & 45.644 & -113.652 & $7 / 10 / 2003$ & DEQ \\
\hline Agapetus montanus & Bloody Dick Creek & 45.011 & -113.257 & $7 / 26 / 2004$ & DEQ \\
\hline Agapetus montanus & Bloody Dick Creek & 45.017 & -113.498 & $7 / 26 / 2004$ & DEQ \\
\hline Agapetus montanus & Bridger Creek & 45.725 & -109.689 & $7 / 31 / 1992$ & DEQ \\
\hline Agapetus montanus & Bridger Creek & 45.700 & -110.929 & $8 / 3 / 2004$ & DEQ \\
\hline Agapetus montanus & Burdette Creek & 46.813 & -114.620 & $7 / 12 / 2001$ & DEQ \\
\hline Agapetus montanus & CALF CREEK & 46.845 & -110.960 & $7 / 29 / 2001$ & USFS \\
\hline Agapetus montanus & California Creek & 45.980 & -113.016 & $7 / 8 / 2005$ & DEQ \\
\hline Agapetus montanus & California Creek & 45.955 & -113.039 & $7 / 12 / 2005$ & DEQ \\
\hline Agapetus montanus & Camas Creek & 46.705 & -111.192 & $8 / 14 / 1995$ & DEQ \\
\hline Agapetus montanus & Clark Fork & 46.187 & -112.768 & $8 / 7 / 2001$ & DEQ \\
\hline Agapetus montanus & Clear Creek & 47.578 & -115.390 & $8 / 9 / 2003$ & DEQ \\
\hline Agapetus montanus & CROW CREEK & 46.251 & -111.674 & $8 / 10 / 2004$ & BLM \\
\hline Agapetus montanus & CROW CREEK & 46.300 & -111.734 & $8 / 10 / 2004$ & USFS \\
\hline Agapetus montanus & Dearborn River - Middle Fork & 47.210 & -112.275 & $7 / 23 / 2003$ & DEQ \\
\hline Agapetus montanus & Dearborn River - South Fork & 47.121 & -112.255 & $8 / 29 / 2002$ & DEQ \\
\hline Agapetus montanus & Dearborn River - South Fork & 47.152 & -112.227 & $8 / 30 / 2002$ & DEQ \\
\hline Agapetus montanus & Dearborn River - South Fork & 47.121 & -112.255 & $7 / 22 / 2003$ & DEQ \\
\hline Agapetus montanus & Dearborn River - South Fork & 47.152 & -112.227 & 7/22/2003 & DEQ \\
\hline Agapetus montanus & DOG CREEK & 46.660 & -112.390 & $8 / 12 / 2004$ & USFS \\
\hline Agapetus montanus & Dry Creek & 46.249 & -111.278 & $7 / 29 / 2005$ & DEQ \\
\hline Agapetus montanus & DRY GULCH CREEK & 46.554 & -111.134 & $8 / 2 / 2001$ & USFS \\
\hline Agapetus montanus & DUTCHMAN CREEK & 46.415 & -111.997 & 8/26/2002 & USFS \\
\hline Agapetus montanus & Elk Ck & 45.627 & -111.414 & $7 / 12 / 2001$ & DEQ \\
\hline Agapetus montanus & Fishtrap Creek & 45.870 & -113.228 & $7 / 16 / 2003$ & DEQ \\
\hline Agapetus montanus & Fortine Creek & 48.672 & -114.898 & $8 / 10 / 2003$ & DEQ \\
\hline Agapetus montanus & Fortine Creek & 48.794 & -114.953 & $8 / 11 / 2003$ & DEQ \\
\hline Agapetus montanus & Fox Creek & 45.272 & -112.359 & $7 / 15 / 2003$ & DEQ \\
\hline Agapetus montanus & French Creek & 45.915 & -113.106 & $7 / 7 / 2005$ & DEQ \\
\hline Agapetus montanus & French Creek & 45.949 & -113.049 & $7 / 8 / 2005$ & DEQ \\
\hline Agapetus montanus & Hound Creek & 47.214 & -111.409 & $7 / 23 / 2004$ & DEQ \\
\hline Agapetus montanus & Jack Creek & 45.379 & -111.641 & $8 / 18 / 1999$ & DEQ \\
\hline Agapetus montanus & Jackson Creek & 45.661 & -110.848 & $7 / 27 / 2004$ & DEQ \\
\hline Agapetus montanus & \begin{tabular}{|l|} 
Johnson Creek \\
\end{tabular} & 45.707 & -113.604 & 6/21/2004 & DEQ \\
\hline Agapetus montanus & Lime Creek & 48.661 & -114.890 & $8 / 12 / 2003$ & DEQ \\
\hline Agapetus montanus & Little Belt Creek & 47.387 & -110.701 & $8 / 24 / 2005$ & DEQ \\
\hline Agapetus montanus & Little Box Elder & 48.233 & -109.587 & 7/9/2005 & DEQ \\
\hline Agapetus montanus & Little Box Elder & 48.301 & -109.557 & $7 / 9 / 2005$ & DEQ \\
\hline Agapetus montanus & LUMP GULCH & 46.474 & -112.085 & $8 / 13 / 2004$ & USFS \\
\hline Agapetus montanus & Medicine Lodge Creek & 44.871 & -113.007 & 7/28/2004 & DEQ \\
\hline Agapetus montanus & Medicine Lodge Creek & 44.751 & -113.036 & $7 / 28 / 2004$ & DEQ \\
\hline Agapetus montanus & Middle Fork Dearborn & 47.193 & -112.291 & $7 / 23 / 2003$ & DEQ \\
\hline Agapetus montanus & Mill Creek & 45.377 & -110.633 & $8 / 16 / 2003$ & DEQ \\
\hline
\end{tabular}




\begin{tabular}{|c|c|c|c|c|c|}
\hline SOC Species & WaterbodyName & Latitude & Longitude & \begin{tabular}{|l|} 
Collection \\
Date
\end{tabular} & Agency \\
\hline Agapetus montanus & Miller Creek - & 46.777 & -113.965 & $7 / 8 / 2004$ & DEQ \\
\hline Agapetus montanus & Mill-Willow Creeks Bypass & 46.183 & -112.777 & $8 / 18 / 2000$ & DEQ \\
\hline Agapetus montanus & Miners Gulch & 46.404 & -113.511 & $8 / 3 / 2004$ & DEQ \\
\hline Agapetus montanus & Moose Creek & 45.744 & -112.671 & $7 / 19 / 2005$ & DEQ \\
\hline Agapetus montanus & Moose Creek & 45.700 & -112.734 & $7 / 19 / 2005$ & DEQ \\
\hline Agapetus montanus & Newlan Creek & 46.628 & -110.979 & $7 / 19 / 2004$ & DEQ \\
\hline Agapetus montanus & North Meadow Creek & 45.441 & -111.710 & $8 / 16 / 1999$ & DEQ \\
\hline Agapetus montanus & Pine Creek & 45.243 & -113.347 & $7 / 15 / 2003$ & DEQ \\
\hline Agapetus montanus & Pole Creek & 45.355 & -113.181 & $7 / 15 / 2004$ & DEQ \\
\hline Agapetus montanus & Rattlesnake Creek & 45.207 & -112.759 & $7 / 20 / 2004$ & DEQ \\
\hline Agapetus montanus & Red Lodge Creek & 45.284 & -109.430 & $8 / 8 / 2003$ & DEQ \\
\hline Agapetus montanus & Reservoir Creek & 45.148 & -113.123 & $7 / 19 / 2004$ & DEQ \\
\hline Agapetus montanus & Seventeen Mile North Fork & 48.660 & -115.760 & $8 / 12 / 2003$ & DEQ \\
\hline Agapetus montanus & Seventeenmile Creek & 48.630 & -115.720 & $8 / 12 / 2003$ & DEQ \\
\hline Agapetus montanus & Silver Bow Creek & 46.107 & -112.804 & $8 / 18 / 2000$ & DEQ \\
\hline Agapetus montanus & Silver Bow Creek & 46.182 & -112.778 & $8 / 16 / 2002$ & DEQ \\
\hline Agapetus montanus & Smart Creek & 46.454 & -113.291 & $8 / 17 / 2005$ & DEQ \\
\hline Agapetus montanus & Sourdough Creek & 45.642 & -111.029 & $8 / 2 / 2004$ & DEQ \\
\hline Agapetus montanus & South Meadow Creek & 45.447 & -111.729 & 8/17/1999 & DEQ \\
\hline Agapetus montanus & Spotted Dog Creek & 46.580 & -112.602 & 8/18/2005 & DEQ \\
\hline Agapetus montanus & SQUAW CREEK & 47.082 & -111.594 & $7 / 12 / 2001$ & DEQ \\
\hline Agapetus montanus & Stone Creek & 45.757 & -110.878 & $7 / 26 / 2004$ & DEQ \\
\hline Agapetus montanus & Swamp Creek & 48.597 & -115.061 & $7 / 12 / 2001$ & DEQ \\
\hline Agapetus montanus & Swamp Creek & 48.602 & -114.961 & $8 / 12 / 2003$ & DEQ \\
\hline Agapetus montanus & Swan Creek & 47.330 & -113.768 & $7 / 12 / 2001$ & DEQ \\
\hline Agapetus montanus & Tenderfoot Creek & 46.951 & -111.164 & $7 / 12 / 2001$ & DEQ \\
\hline Agapetus montanus & TENMILE CREEK & 46.528 & -112.254 & $8 / 12 / 2004$ & USFS \\
\hline Agapetus montanus & Thompson Gulch & 46.562 & -111.177 & $7 / 21 / 2004$ & DEQ \\
\hline Agapetus montanus & Thompson Gulch & 46.600 & -111.125 & $7 / 21 / 2004$ & DEQ \\
\hline Agapetus montanus & Trail Creek & 46.565 & -110.512 & 6/26/2005 & DEQ \\
\hline Agapetus montanus & Warm Springs Creek & 46.181 & -112.783 & $8 / 18 / 2000$ & DEQ \\
\hline Agapetus montanus & Willow Creek & 46.074 & -112.863 & $7 / 14 / 2004$ & DEQ \\
\hline Agapetus montanus & Yaak River North Fork & 48.970 & -115.620 & $8 / 13 / 2003$ & DEQ \\
\hline Cascadoperla trictura & Ninemile Creek & 47.082 & -114.439 & $8 / 2 / 1993$ & DEQ \\
\hline Cascadoperla trictura & Ninemile Creek & 47.083 & -114.441 & $8 / 2 / 1993$ & DEQ \\
\hline Caudatella edmundsi & Burnt Fork Bitterroot Creek & 46.385 & 113.863 & $7 / 20 / 2003$ & USFS \\
\hline Caudatella edmundsi & Butler Creek & 47.126 & 114.437 & $7 / 12 / 2006$ & NHP \\
\hline Caudatella edmundsi & Coyle Creek & 47.258 & 115.272 & $8 / 2 / 2006$ & NHP \\
\hline Caudatella edmundsi & Dempsy Creek & 46.310 & 112.939 & $8 / 19 / 2003$ & USFS \\
\hline Caudatella edmundsi & Doolittle Creek & 45.718 & -113.345 & $6 / 19 / 2003$ & DEQ \\
\hline Caudatella edmundsi & Farlin Creek & 45.339 & -113.120 & $7 / 7 / 2004$ & DEQ \\
\hline Caudatella edmundsi & Gold Creek & 45.616 & -113.084 & $7 / 10 / 2003$ & DEQ \\
\hline Caudatella edmundsi & Grasshopper Creek & 45.474 & -113.120 & $9 / 15 / 2004$ & DEQ \\
\hline Caudatella edmundsi & Green Creek & 47.258 & 115.272 & $8 / 2 / 2006$ & NHP \\
\hline Caudatella edmundsi & Grizzly Creek & 46.575 & 113.657 & $8 / 1 / 2006$ & NHP \\
\hline Caudatella edmundsi & Johnson Creek & 45.707 & -113.604 & 6/21/2004 & DEQ \\
\hline Caudatella edmundsi & Johnson Creek & 45.771 & -113.731 & 6/22/2004 & DEQ \\
\hline Caudatella edmundsi & Kennedy Creek & 47.165 & 114.423 & 7/12/2006 & NHP \\
\hline
\end{tabular}




\begin{tabular}{|c|c|c|c|c|c|}
\hline SOC Species & WaterbodyName & Latitude & Longitude & \begin{tabular}{|l|} 
Collection \\
Date
\end{tabular} & Agency \\
\hline Caudatella edmundsi & LaMarche Creek & 45.911 & -113.217 & $7 / 16 / 2003$ & DEQ \\
\hline Caudatella edmundsi & LaMarche Creek & 45.878 & -113.199 & $7 / 16 / 2003$ & DEQ \\
\hline Caudatella edmundsi & Lick Creek & 46.092 & -114.192 & $7 / 14 / 2004$ & DEQ \\
\hline Caudatella edmundsi & Lost Creek & 46.221 & 113.030 & $7 / 20 / 2003$ & USFS \\
\hline Caudatella edmundsi & McCormick Creek & 47.153 & -114.487 & $7 / 24 / 2003$ & DEQ \\
\hline Caudatella edmundsi & Mormon Creek & 46.709 & 114.210 & $7 / 11 / 2006$ & NHP \\
\hline Caudatella edmundsi & North Creek & 46.739 & -114.573 & $7 / 7 / 2004$ & DEQ \\
\hline Caudatella edmundsi & North Fork Second Creek & 47.164 & 114.711 & $8 / 2 / 2006$ & NHP \\
\hline Caudatella edmundsi & Prospect Creek & 47.576 & 115.643 & $8 / 3 / 2006$ & NHP \\
\hline Caudatella edmundsi & Racetrack Creek & 46.276 & 112.913 & $8 / 18 / 2003$ & USFS \\
\hline Caudatella edmundsi & Ranch Creek & 46.526 & 113.623 & $7 / 17 / 2002$ & USFS \\
\hline Caudatella edmundsi & Rock Creek & 46.408 & 112.968 & $7 / 15 / 2004$ & USFS \\
\hline Caudatella edmundsi & Seymour Creek & 45.990 & -113.184 & $7 / 26 / 1991$ & DEQ \\
\hline Caudatella edmundsi & Seymour Creek & 45.999 & -113.187 & $7 / 19 / 1993$ & DEQ \\
\hline Caudatella edmundsi & South Fork Trout Creek & 46.988 & 114.997 & 8/3/2006 & NHP \\
\hline Caudatella edmundsi & Stony Creek & 46.338 & 113.628 & 6/24/2004 & NHP \\
\hline Caudatella edmundsi & Stony Creek & 47.109 & 114.397 & $7 / 12 / 2006$ & NHP \\
\hline Caudatella edmundsi & Tin Cup Joe Creek & 46.386 & 112.896 & $7 / 20 / 2003$ & USFS \\
\hline Caudatella edmundsi & Trail Creek & 45.657 & -113.809 & $6 / 22 / 2004$ & DEQ \\
\hline Caudatella edmundsi & trib to McCormick Creek & 47.173 & 114.430 & 7/12/2006 & NHP \\
\hline Caudatella edmundsi & Unnamed trib to Big Creek & 47.326 & 115.426 & $8 / 1 / 2006$ & NHP \\
\hline Caudatella edmundsi & Unnamed trib to Big Creek & 47.326 & 115.426 & $8 / 1 / 2006$ & NHP \\
\hline Caudatella edmundsi & Unnamed trib to M. Fork Big Creek & 47.316 & 115.434 & $8 / 1 / 2006$ & NHP \\
\hline Caudatella edmundsi & Van Ness Creek & 47.082 & 114.936 & $8 / 2 / 2006$ & NHP \\
\hline Caudatella edmundsi & Warm Springs Creek & 45.454 & -113.299 & $6 / 21 / 2003$ & DEQ \\
\hline Caudatella edmundsi & Warm Springs Creek & 46.175 & 113.156 & $6 / 30 / 2004$ & NHP \\
\hline Caudatella edmundsi & WEST FORK LOLO CREEK & 46.686 & -114.558 & $10 / 22 / 2002$ & DEQ \\
\hline Caudatella edmundsi & Willow Creek & 45.448 & -112.828 & $7 / 16 / 2004$ & DEQ \\
\hline Caudatella edmundsi & Willow Creek & 45.438 & -112.742 & $7 / 17 / 2004$ & DEQ \\
\hline Caudatella edmundsi & Willow Creek & 45.448 & -112.828 & $7 / 26 / 2005$ & NHP \\
\hline Caudatella edmundsi & Wise River & 45.615 & -113.089 & $7 / 13 / 2005$ & NHP \\
\hline Caurinella idahoensis & Prospect Creek & 47.576 & 115.643 & 3-Aug-06 & NHP \\
\hline Caurinella idahoensis & Unnamed trib to Big Creek & 47.326 & 115.426 & 1-Aug-06 & NHP \\
\hline Caurinella idahoensis & Van Ness Creek & 47.08209 & 114.93553 & 1-Aug-06 & NHP \\
\hline Goereilla baumanni & Butler Creek & 47.014 & 113.999 & 14-May-70 & Newell \\
\hline Goereilla baumanni & Kennedy Creek & 47.165 & 114.423 & 12-Jul-06 & NHP \\
\hline Goereilla baumanni & Quartz Creek & 46.805 & -115.444 & 12-Jul-05 & MSU \\
\hline Goereilla baumanni & Yellow Bay Creek & 47.877 & 113.989 & 25-Apr-78 & Newell \\
\hline Margaritifera falcata & $\begin{array}{l}\text { Big Hole R. East West Rec Area-- } \\
\text { east bank }\end{array}$ & 45.437 & -112.564 & 6-Aug-05 & NHP \\
\hline Margaritifera falcata & Big Hole R. -Notch Bottom & 45.437 & -112.564 & 7-Aug-05 & D.L. Gustafson \\
\hline Margaritifera falcata & Blackfoot R. -Mineral Hill & 46.942 & -112.948 & 12-Jun-94 & D.L. Gustafson \\
\hline Margaritifera falcata & Clam Creek & & & 15-Jul-05 & P. Mundy \\
\hline Margaritifera falcata & Clearwater R. above Seeley Lake & 47.235 & -113.538 & 15-Sep-94 & USFS \\
\hline Margaritifera falcata & Clearwater R. above Seeley Lake & 47.226 & -113.537 & 15-Jul-06 & NHP \\
\hline Margaritifera falcata & Clearwater R. above Seeley Lake & 47.219 & -113.535 & 15-Jul-06 & NHP \\
\hline Margaritifera falcata & Colt Creek & 47.326 & -113.597 & 11-Jun-01 & USFS \\
\hline
\end{tabular}

Appendix B - 3 


\begin{tabular}{|c|c|c|c|c|c|}
\hline SOC Species & WaterbodyName & Latitude & Longitude & $\begin{array}{l}\text { Collection } \\
\text { Date }\end{array}$ & Agency \\
\hline Margaritifera falcata & $\begin{array}{l}\text { Deep Creek-BLM access @ Conner } \\
\text { Creek }\end{array}$ & 45.897 & -113.109 & 6-Aug-05 & NHP \\
\hline Margaritifera falcata & $\begin{array}{l}\text { Deep Creek-BLM access @ Conner } \\
\text { Creek }\end{array}$ & 45.886 & -113.117 & 6-Aug-05 & NHP \\
\hline Margaritifera falcata & East Gallatin R. -Upper Cherry & 45.714 & -111.049 & 17-Sep-98 & D.L. Gustafson \\
\hline Margaritifera falcata & Finley Creek & & & 01-Jun-05 & McGuire \\
\hline Margaritifera falcata & $\begin{array}{l}\text { Grasshopper Creek, nr. Bannock } \\
\text { State Park, Yankee Flats }\end{array}$ & 45.160 & -112.986 & 8-Aug-96 & FWP \\
\hline Margaritifera falcata & $\begin{array}{l}\text { Grasshopper Creek, nr. Bannock } \\
\text { State Park, Yankee Flats }\end{array}$ & 45.160 & 112.986 & 8-Aug-96 & NHP \\
\hline Margaritifera falcata & $\begin{array}{l}\text { IDAH: Blaine Co. Silver Cr. -BLM } \\
\text { South Site }\end{array}$ & 43.246 & -113.995 & 17-Jul-04 & D.L. Gustafson \\
\hline Margaritifera falcata & $\begin{array}{l}\text { IDAH: Clearwater Co., N.Fk Clear- } \\
\text { water R. }\end{array}$ & 46.720 & -115.292 & 27-Jul-03 & D.L. Gustafson \\
\hline Margaritifera falcata & $\begin{array}{l}\text { IDAH: Custer Co., Pahsimeroi R. } \\
\text {-mouth }\end{array}$ & 44.691 & -114.048 & 30-Apr-00 & D.L. Gustafson \\
\hline Margaritifera falcata & $\begin{array}{l}\text { IDAH: Custer Co., Salmon R. } \\
\text {-Penal Gulch }\end{array}$ & 44.545 & -114.180 & 2-Sep-01 & D.L. Gustafson \\
\hline Margaritifera falcata & $\begin{array}{l}\text { IDAH: Idaho Co., Meadow Cr. } \\
\text {-Selway Falls }\end{array}$ & 46.040 & -115.294 & 1-Jul-02 & D.L. Gustafson \\
\hline Margaritifera falcata & $\begin{array}{l}\text { IDAH: Idaho Co., Red R. -Mother } \\
\text { Lode Hill }\end{array}$ & 45.802 & -115.412 & 1-Jul-02 & D.L. Gustafson \\
\hline Margaritifera falcata & $\begin{array}{l}\text { IDAH: Idaho Co., Red R. -Red } \\
\text { Horse Cr. }\end{array}$ & 45.790 & -115.395 & 6-Aug-05 & D.L. Gustafson \\
\hline Margaritifera falcata & $\begin{array}{l}\text { IDAH: Lemhi Co., Mid Fk Salmon } \\
\text { R. -mouth }\end{array}$ & 45.301 & -114.571 & 1-Sep-01 & D.L. Gustafson \\
\hline Margaritifera falcata & $\begin{array}{l}\text { IDAH: Lemhi Co., Salmon R. } \\
\text {-Deer Gulch }\end{array}$ & 44.703 & -114.043 & 1-Sep-01 & D.L. Gustafson \\
\hline Margaritifera falcata & $\begin{array}{l}\text { IDAH: Madison Co., Henrys Fork } \\
\text {-ID } 33 \mathrm{Br} \text {. }\end{array}$ & 43.827 & -111.904 & 5-Sep-98 & D.L. Gustafson \\
\hline Margaritifera falcata & $\begin{array}{l}\text { IDAH: Shoshone Co. St. Joe R. } \\
\text {-Conrad Crossing }\end{array}$ & 47.160 & -115.420 & 5-Jul-03 & D.L. Gustafson \\
\hline Margaritifera falcata & $\begin{array}{l}\text { IDAH: Teton Co., Teton R. -Buxton } \\
\text { Br. }\end{array}$ & 43.723 & -111.189 & 31-Aug-03 & D.L. Gustafson \\
\hline Margaritifera falcata & Little Thompson Creek & 47.6917 & 114.8111 & 22-Jul-01 & USFS \\
\hline Margaritifera falcata & Little Thompson R. +Nancy Cr. & 47.706 & -114.787 & 1-Sep-94 & P. Winebrenner \\
\hline Margaritifera falcata & Madison R. -Bakers Hole & 44.716 & -111.102 & 19-Oct-95 & D.L. Gustafson \\
\hline Margaritifera falcata & Madison R. -Cherry Cr. & 45.623 & -111.550 & 15-Aug-83 & D.L. Gustafson \\
\hline Margaritifera falcata & Madison R. -old Beartrap Br. & 45.591 & -111.576 & 13-Jul-02 & D.L. Gustafson \\
\hline Margaritifera falcata & Madison R. -old Beartrap Br. & 45.591 & -111.576 & 25-Jul-04 & D.L. Gustafson \\
\hline Margaritifera falcata & Monture Cr. -Monture FAS & 47.037 & -113.219 & 31-Oct-98 & D.L. Gustafson \\
\hline Margaritifera falcata & North Fk Yaak R. 1 mi. -Canada & 48.984 & -115.626 & 8-Oct-92 & FWP \\
\hline Margaritifera falcata & North Fork Lower Willow Creek & & & 01-Sep-05 & McGuire \\
\hline Margaritifera falcata & Pistol Creek & & & 01-Jun-05 & McGuire \\
\hline Margaritifera falcata & Smith R. +Beaver Cr. & 46.754 & -111.173 & 24-Oct-05 & NHP \\
\hline Margaritifera falcata & $\begin{array}{l}\text { Smith R. -Trout Cr., dn from Trout } \\
\text { Creek campground }\end{array}$ & 47.050 & -111.276 & 17-Apr-04 & NHP \\
\hline Margaritifera falcata & Smith River dn Rock Creek & & & 19-Apr-05 & NHP \\
\hline Margaritifera falcata & Sunday Cr. -mouth & 48.632 & -114.708 & 7-Sep-94 & NHP \\
\hline Margaritifera falcata & Trail Cr. -lowest $43 \mathrm{Br}$. & 45.643 & -113.691 & 4-Oct-96 & D.L. Gustafson \\
\hline
\end{tabular}




\begin{tabular}{|c|c|c|c|c|c|}
\hline SOC Species & WaterbodyName & Latitude & Longitude & \begin{tabular}{|l|} 
Collection \\
Date
\end{tabular} & Agency \\
\hline Margaritifera falcata & Trail Cr. -lowest $43 \mathrm{Br}$. & 45.643 & -113.691 & 26-Jul-97 & D.L. Gustafson \\
\hline Margaritifera falcata & Upper Willow Creek & 46.507 & -113.507 & 01-Sep-05 & McGuire \\
\hline Margaritifera falcata & West Fk Rock Cr. & 46.192 & -113.702 & 16-Jun-95 & USFS \\
\hline Margaritifera falcata & $\begin{array}{l}\text { WYOM: Teton Co., Crawfish Cr. } \\
\text {-mouth }\end{array}$ & 44.151 & -110.675 & 15-Aug-84 & D.L. Gustafson \\
\hline Margaritifera falcata & $\begin{array}{l}\text { WYOM: Teton Co., Little Firehole } \\
\text { R. -mouth }\end{array}$ & 44.483 & -110.853 & 24-Aug-88 & D.L. Gustafson \\
\hline Margaritifera falcata & WYOM: Teton Co., Madison R. & 44.649 & -110.947 & 23-Sep-79 & D.L. Gustafson \\
\hline Margaritifera falcata & $\begin{array}{l}\text { WYOM: Teton Co., Polecat Cr. } \\
\text {-low Br. }\end{array}$ & 44.108 & -110.684 & 25-Jun-01 & D.L. Gustafson \\
\hline Rossiana montana & Coyle Creek & 47.258 & -115.272 & 2-Aug-06 & NHP \\
\hline Rossiana montana & Green Creek & 47.258 & 115.272 & 2-Aug-06 & NHP \\
\hline Rossiana montana & Kennedy Creek & 47.165 & 114.423 & 12-Jul-06 & NHP \\
\hline Rossiana montana & Mormon Creek & 46.709 & 114.210 & 11-Jul-06 & NHP \\
\hline Rossiana montana & North Fork Second Creek & 47.164 & 114.711 & 2-Aug-06 & NHP \\
\hline Rossiana montana & Prospect Creek & 47.576 & 115.643 & 3-Aug-06 & NHP \\
\hline Rossiana montana & South Fork Trout Creek & 46.988 & 114.997 & 3-Aug-06 & NHP \\
\hline Sericostriata surdickae & Big Boulder Creek & 45.576 & -116.069 & 12-Aug-04 & USFS \\
\hline Sericostriata surdickae & Burnt Fork Bitterroot Creek & 46.385 & 113.863 & 20-Jul-03 & USFS \\
\hline Sericostriata surdickae & Canyon Creek & 44.193 & -115.247 & 12-Aug-04 & USFS \\
\hline Sericostriata surdickae & Coyle Creek & 47.258 & -115.272 & 2-Aug-06 & NHP \\
\hline Sericostriata surdickae & French Creek & 44.526 & -116.112 & 11-Aug-04 & USFS \\
\hline Sericostriata surdickae & Green Creek & 47.315 & -115.488 & 2-Aug-06 & NHP \\
\hline Sericostriata surdickae & Lost Creek & 46.221 & 113.030 & 20-Jul-03 & USFS \\
\hline Sericostriata surdickae & Porter Creek & 44.4542 & -115.508 & 01-Aug-02 & USFS \\
\hline Sericostriata surdickae & Porter Creek & 44.4542 & -115.508 & 01-Aug-03 & USFS \\
\hline Sericostriata surdickae & Prospect Creek & 47.576 & 115.643 & 3-Aug-06 & NHP \\
\hline Sericostriata surdickae & Ranch Creek & 46.526 & 113.623 & 17-Jul-02 & USFS \\
\hline Sericostriata surdickae & Rock Creek & 46.408 & 112.968 & 20-Jul-03 & USFS \\
\hline Sericostriata surdickae & Rock Creek & 46.408 & 112.968 & 15-Jul-04 & USFS \\
\hline Sericostriata surdickae & Simmons Creek & \begin{tabular}{|l|}
45.8676 \\
\end{tabular} & -115.219 & \begin{tabular}{|l|} 
19-Jul-03 \\
\end{tabular} & USFS \\
\hline Sericostriata surdickae & South Fork Trout Creek & 46.988 & 114.997 & 3-Aug-06 & NHP \\
\hline Sericostriata surdickae & Swet Creek & 45.569 & -114.766 & 19-Aug-03 & USFS \\
\hline Sericostriata surdickae & Swet Creek & 45.569 & -114.766 & 12-Aug-04 & USFS \\
\hline Sericostriata surdickae & Tin Cup Joe Creek & 46.386 & -112.896 & 19-Jul-03 & USFS \\
\hline Soliperla salish & Fern Creek & 46.862 & -115.622 & 7/4/2001 & MSU \\
\hline Soliperla salish & Gorman Creek & 46.672 & -115.078 & 7/5/2001 & MSU \\
\hline Soliperla salish & Lt. N.Fk Clearwater R. trib & 47.065 & -115.851 & $7 / 4 / 2001$ & MSU \\
\hline Soliperla salish & Prospect Creek & 47.576 & -115.643 & 8/3/2006 & NHP \\
\hline Soliperla salish & Unnamed trib to Big Creek & 47.326 & -115.426 & $8 / 2 / 2006$ & NHP \\
\hline Soliperla salish & Van Ness Creek & 47.089 & -114.928 & 7/3/2001 & MSU \\
\hline Soliperla salish & Van Ness Creek & 47.081 & -114.937 & 8/2/2006 & NHP \\
\hline Soyedina potteri & Kennedy Creek & 47.165 & 114.423 & 12-Jul-06 & NHP \\
\hline Soyedina potteri & trib to McCormick Creek & 47.173 & 114.430 & 12-Jul-06 & NHP \\
\hline Soyedina potteri & Unnamed trib to Big Creek & 47.326 & 115.426 & 1-Aug-06 & NHP \\
\hline Soyedina potteri & Unnamed trib M. Fork Big Creek & 47.316 & 115.434 & 1-Aug-06 & NHP \\
\hline
\end{tabular}





\section{Appendix C. Selected Aquatic SOI and Potential SOC SPECIES ACCOUNTS}





\section{A. Taxonomy}

Order: Bivalvia

Family: Margaritiferidae

Margaritifera falcata (Gould 1850)

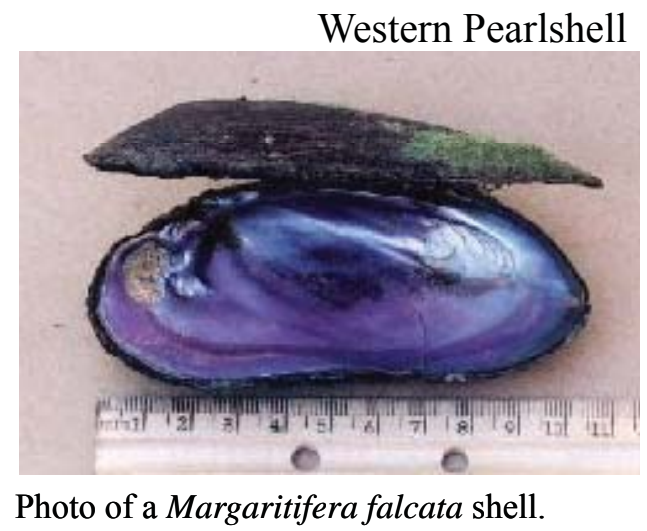

Populations east of the continental divide in the tributaries of the Missouri River of Montana were included with the eastern pearlshell, Margaritifera margaritifera by some authors, although they share the trait of purple nacre with $M$. falcata of the Pacific drainages and are hereafter considered M. falcata (after Gustafson 2001). The true M. margaritifera of the Atlantic slope have white nacre. There is a potential new species of Margaritifera in one drainage of Idaho, the Pahsimeroi pearlshell (Margartifera sp1.) (Frest \& Johannes 1999), but at the time of this report, it has not been described as a distinct species, and given the previous track record of Frest and Johannes new species accounts (all Fluminicola new spp. were dropped from ID and MT Heritage Programs track list), it is likely that this population is just a variant form of $M$. falcata.

\section{B. Species Description}

Shell Morphology: The shell of $M$. falcata is elongate, compressed, dark colored, and slightly concave on the ventral edge, oftentimes erosion marks are prominent on the umbo region (see photo). It is the smallest mussel species in Montana and the only one known west of the continental divide. It has weakly developed teeth and a purple nacre (see photo). The normal size is 50 to $85 \mathrm{~mm}$ with larger older specimens surpassing $10 \mathrm{~cm}$. In Montana, this species is similar to Ligumia recta, which is larger, thicker and has better developed teeth, pink nacre and occurs only in warmer rivers much further downstream. Since these species occur in very different habitats the likelihood of misidentifying $M$. falcata in Montana is virtually impossible.

Reproductive Biology: Nearly all mussels (Unionidae) require a host or hosts during the parasitic larval portion of their life cycle. Hosts are usually fish species and hosts for $M$. falcata in this region were typically and historically Oncorhynchus spp. (Chinook Salmon, Westslope Cutthroat trout, Steelhead, etc.), but Salmo and Salvelinus (introduced spp.) and even Rhinicthys and Catostomus (dace and suckers) are reported to be suitable.

Ecology: This species occurs in sand, gravel and even among cobble and boulders in low to moderate gradient streams up to larger rivers. In large Idaho river systems (Salmon and Clearwater River Canyons), M. falcata, attains maximum density and age in river reaches where large boulders structurally stabilize cobbles and interstitial gravels. Boulders tend to prevent significant bed scour during major floods, and these boulder-sheltered mussel beds, although rare, may be critical for population recruitment elsewhere within the river, especially after periodic flood scour of less protected mussel habitat. Locally, canyon reaches are aggrading with sand and gravel, and $M$. falcata is being replaced by Gonidea angulata. 


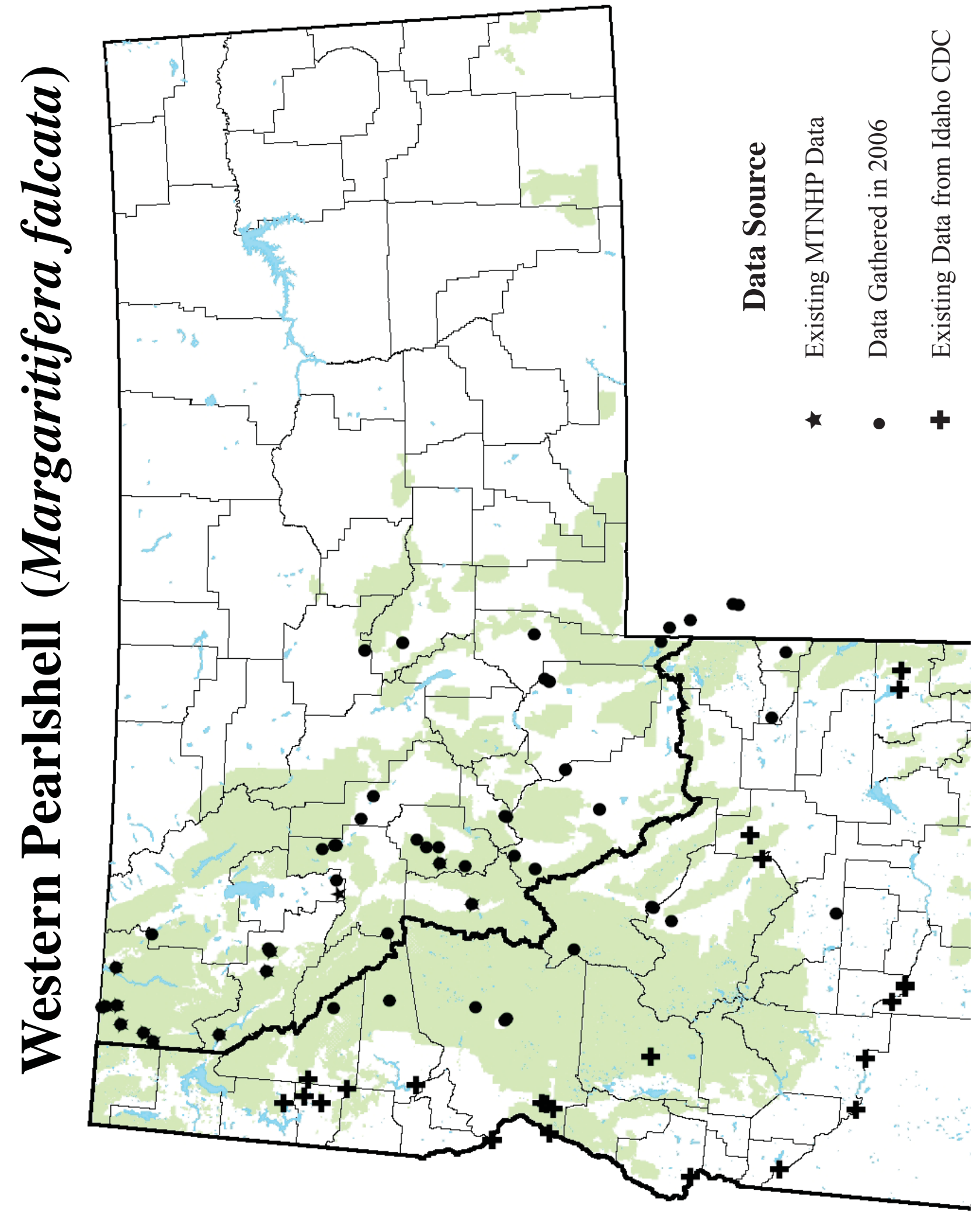

Appendix C - 2 


\section{Range and Known Sites}

Rangewide, Margaritifera falcata is found in Alaska (SNR), California (S2S3), Idaho (S3), Montana (S2S4), Nevada (SNR), Oregon (S3), Utah (SH), Washington (S4), Wyoming (SNR) and British Columbia (S5) (Nature Serve 2006). Their range is widespread in area, but spotty in viable population coverage.

In Idaho, the historical range includes sites in the Snake, Coeur d'Alene, Lost, and Salmon River drainages (Frest and Johannes 1997, Frest 1999). Populations are thought to persist in north Idaho in the Coeur d'Alene, St. Joe, and St. Maries Rivers. Incentral Idaho, populations with good viability occur in the Clearwater, Selway, Lochsa, Pahsimeroi, Lost, Salmon and Little Salmon rivers and in Hells Canyon. In south Idaho, populations are thought to be extant in the upper tributaries of the Snake River, including the Blackfoot River (Frest and Johannes1997, Frest 1999).

Montana's populations of $M$. falcata, in contrast to Idaho's, may be significantly contracting and becoming less viable with stream decreased flows, warming and degradation. Previously reported mussel beds in the larger rivers (Blackfoot, Big Hole, Bitterroot, Clark Fork, etc.) are extirpated from the drainage or are at such low densities, long-term viability is unlikely. This mussel species appears to have crossed the continental divide in Montana from west to east with its salmonid host, the westslope cutthroat trout, Oncorhynchus clarki lewisi (Gustafson 2001). This is the only native trout in the Missouri River headwaters. Reports of the eastern M. margaritifera in Montana are apparently due to the mistaken assumption that a mussel could not cross the continental divide.

\section{Species Abundance}

Global Abundance Estimate: 2,500 - 10,000 individuals. This estimate seems somewhat low because mussel beds on the Selway and Salmon Rivers of ID each ranged into the 100's of individuals (D. Stagliano, pers. obs.) and one large population in Montana in one stream reach was estimated at $\sim 1000$ individuals (D. McGuire, pers. comm.). According to Frest (1999) the area occupied, the number of sites occupied, and population sizes have decreased. Populations formerly existed in the middle Snake River, but Frest (1999) was unable to find live individuals in this reach. Revisits to old ( $>20$ years) sightings in stream reaches of the Bitterroot and Clark Fork Rivers have been conducted (Stagliano, unpublished data) and no populations were found to exist.

\section{Current Status}

\section{A. Why Species is of Conservation Concern}

Margaritifera falcata is a Species-of-Interest (CFWS T1) for the USFS, and a Potential Species of Concern in Montana (S2S4). However, compared to Idaho, Montana's populations have showed more dramatic declines (Gustafson, pers. comm.) and will probably become at least a S3 after next years surveys. This species is widespread in geographic area, but is declining in terms of area occupied and the number of sites with viable individuals; populations showing repeated reproduction (at least several age classes) are now the exception rather than the rule (Frest \& Johannes 1995). Clarke (1993) asserted that "over-utilization of water resources by man" is responsible for the extirpation of this species in Utah. Individuals of this species can be quite long-lived; populations could exist undetected at low levels for many years. 
Global Short Term Trend: Declining (decline of 10-30\%)

Global Short Term Trend Comments: Taxon is declining, in terms of area occupied and number of sites and individuals (Frest \& Johannes 1995; Hoving 2004). This species has likely recently been extirpated from the Umatilla River in Oregon (Brim Box et al. 2003).

Global Long Term Trend: Substantial to moderate decline (decline of 25-75\%)

Global Long Term Trend Comments: All 11 localities (perhaps 9 populations) in Utah have been extirpated; it formerly occurred in the northern third of the state (Oliver \& Bosworth, 1999).

\section{B. Threats}

Specific threats to all populations of $M$. falcata, including extensive damming and diversion of rivers for irrigation, hydroelectric, and water supply projects has much reduced the WA, OR, ID, and CA range of this species. Heavy nutrient enhancement, siltation, unstable substrate, or similar problems extirpate populations. Much of the middle Snake River in Idaho is rapidly becoming eutropified, due to agricultural runoff, fish farms, and urbanization along the river corridor. Much of the river is impounded behind a series of small dams; this is also detrimental for cold-water species such as this taxon. Fine sediment influx, generally from the same causes, is also a major problem. A recent (1994) landslide impacted some of the historic sites in the Snake River basin. In the lower Columbia River region, threats include impoundments; continued siltation and other impacts on the few remaining sites with habitat characteristics approximating pre-impoundment conditions on the lower Columbia.

\section{Distribution Relative to Land Allocations}

Distribution of this species in the Northern Region 1 managed forest lands accounts for about $35 \%$ of the known occurrences, more sites in Idaho occur within USFS managed lands. High quality Margaritfera mussel beds are located in the Clearwater, Selway, Lochsa, Pahsimeroi, Lost, Salmon and Little Salmon rivers which flow extensively within the Clearwater, Bitterroot, Nez Perce, Salmon-Challis National Forests The other majority of occurrences are within privately-owned river corridors where access is from county road bridges or by floating. Many BLM managed lands contain this species where the National Forest lands transition to the foothills and valleys. 


\section{A. Taxonomy}

Order: Plecoptera

Family: Capniidae

Capnia lineata Hanson, 1943

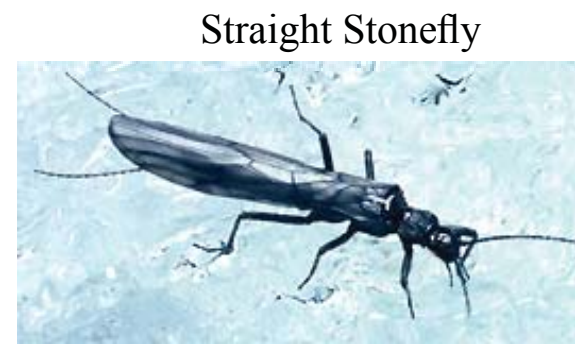

Photo of Capnia from Colorado (not lineatai) taken by C. Riley used from The Tree of Life Web Project. http://tolweb.org/Capniidae/13941

Type Locality: Troy, Idaho.

At one time, C. lineata and C. zukeli were considered synonyms. The original descriptions of the two taxa and figures of female specimens (Hanson 1943: 85-86 as referenced in Nelson and Baumann 1989) later proved to be inadequate for separating females of the two species. With the availability of additional specimens, proper associations were made, and the two taxa were recognized as distinct (Baumann, Gaufin, and Surdick 1977; Nelson and Baumann 1989).

\section{B. Species Description}

Adult Morphology: Capnia lineata belongs to the Vernalis Species-Group in the genus Capnia and includes two other species, C. confusa and C. vernalis. The species in the Vernalis Group are distinguished "by the synapomorphic characters of a medial bridge or bridge vestige between the abdominal sternites 7 and 8 of the female. The epiproct of the male is produced as a tube with little modification. The abdominal tergites of males are without knobs" (Nelson \& Baumann 1989). "The male of this species most closely resembles that of C. confusa. The two are distinguished on the basis of the relatively longer epiproct of $C$. lineata. All examined male specimens of $C$. lineata have been short-winged, while those of the other two species in the group are longer winged" (Nelson and Baumann 1989).

Reproductive Biology: The adults emerge in March and April (Baumann, Gaufin, and Surdick 1977).

Ecology: This species is often collected with C. zukeli and C. venosa (Nelson and Baumann 1989). Capnia lineata occurs in creeks in northern Idaho (Baumann, Gaufin, and Surdick 1977). Merritt and Cummins (1996) describe the trophic functional group of Capnia larvae as shreddersdetritivores.

\section{Range and Known Sites}

The geographic range of the species includes California and Idaho. In Idaho, the species is known only from 9 streams in the Troy area, Latah County (Nelson and Baumann 1989; Baumann, Gaufin, and Surdick 1977; Baumann personal communication 2005). 


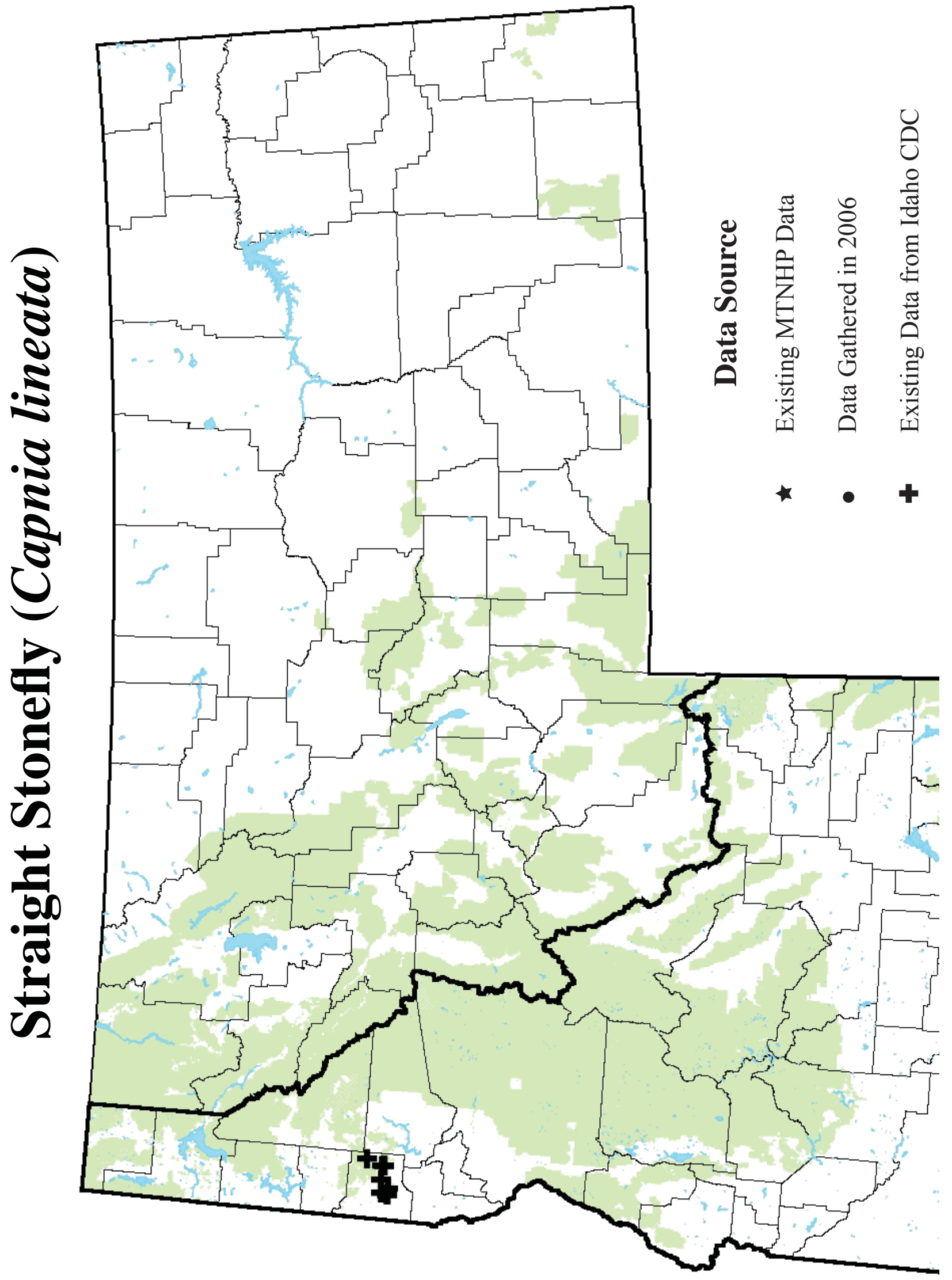

Appendix C - 6 


\section{Species Abundance}

Specimens on-hand at Brigham Young University (Baumann personal communication 2005) indicate that collections ranged from as few as 2 adult specimens at a single location on one date to as many as 87 adult specimens at different location on a single date.

\section{Current Status}

\section{A. Why Species is of Conservation Concern}

Baumann, Gaufin, and Surdick (1977) reported that C. lineata is a "rare species." The species is known in Idaho from only a general locality---i.e., "several creeks in the Troy area" (Nelson and Baumann 1989).

\section{B. Threats}

Specific threats to Idaho populations of $C$. lineata have not been identified.

In general, stonefly populations are affected by changes to aquatic habitat such as alteration of flow patterns, streambed substrate, thermal characteristics, and water quality. Alteration and degredation of aquatic habitat is the primary concern for Idaho populations.

\section{Distribution Relative to Land Allocations}

Based on available information, five of the nine Latah County collection locations are streams flowing through private lands. The other four collections were made within a National Forest near the interface with private lands. 


\section{A. Taxonomy}

Order: Plecoptera

Family: Capniidae

Capnia zukeli Hanson, 1943

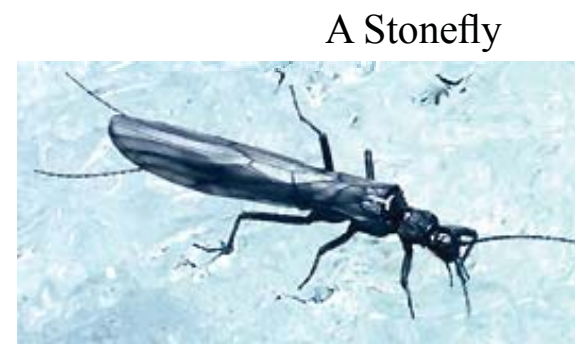

Photo of Capnia from Colorado (not zukeli) taken by C. Riley used from The Tree of Life Web Project. http://tolweb.org/Capniidae/13941

Type locality: Moscow, 2560 ft., Latah County, Idaho.

At one time, C. lineata and C. zukeli were considered synonyms. Capnia zukeli lives in the same area with C. venosa and C. lineata. Capnia zukeli resembles C. lineata "but seems to be distinct from it in both sexes" (Nelson and Baumann 1989). The original descriptions of the two taxa and figures of female specimens (Hanson 1943: 85-86 as referenced in Nelson and Baumann 1989) proved to be inadequate for separating females of the two species. The two taxa were reinstated as distinct species following the examination of additional specimens (Baumann, Gaufin, and Surdick 1977; Nelson and Baumann 1989).

\section{B. Species Description}

Adult Morphology: In the male, the extremely long epiproct (30 times as long as wide), the absence of tergal knobs, and brachyptery distinguish this species from all others in the genus Capnia (Nelson and Baumann 1989). Female body length is $9 \mathrm{~mm}$; forewing length is $7.8 \mathrm{~mm}$. The subgenital plate has a straight and recessed hind margin; muscle insertions lateral to the posterior margin are darkly colored. Small, spurious sclerites are absent from the membrane between sterna 7 and 8 (Nelson and Baumann 1989).

Reproductive Biology: Adults have been captured in April (Nelson and Baumann 1989; Baumann personal communication 2005).

Ecology: No habitat information was available, but generally Capniidae prefer small streams and springs. Merritt and Cummins (1996) consider the trophic functional group of Capnia larvae to be shredders-detritivores.

\section{Range and Known Sites}

Capnia zukeli is an Idaho endemic species known from 7 different locations in Latah County (Nelson and Baumann 1989).

\section{Species Abundance}

Specimens at Brigham Young University (Baumann personal communication 2005) indicate that 12 males and 62 females were collected on one date at one Latah County location. 


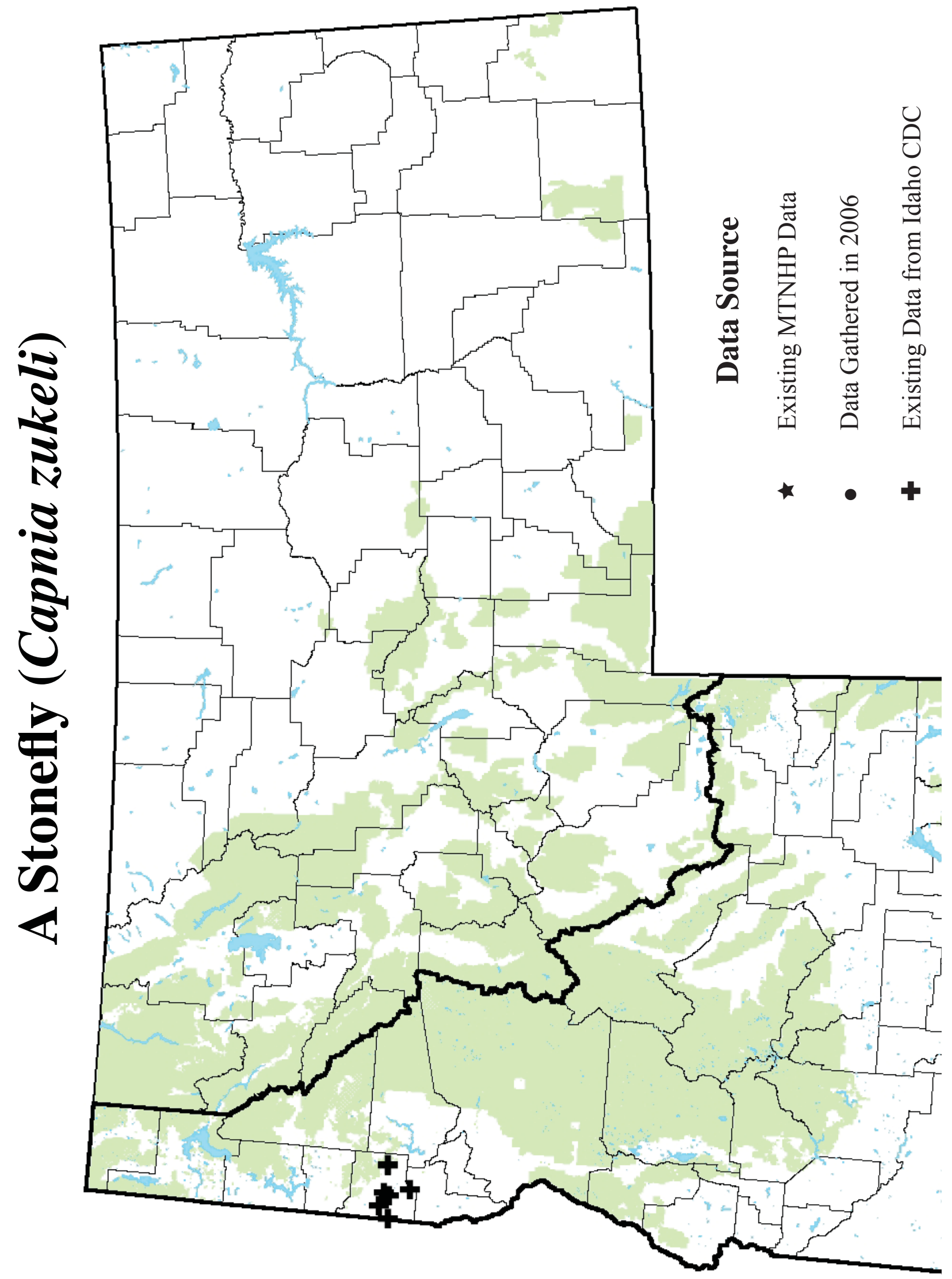

Appendix C - 9 


\section{Current Status}

\section{A. Why Species is of Conservation Concern}

Capnia zukeli is an Idaho endemic species known only from Latah County (Nelson and Baumann 1989).

\section{B. Threats}

Specific threats to Idaho populations of $C$. zukeli have not been identified. In general, stonefly populations are affected by changes to aquatic habitat such as alteration of flow patterns, streambed substrate, thermal characteristics, and water quality. Alteration and degredation of aquatic habitat is the primary concern for Idaho populations.

\section{Distribution Relative to Land Allocations}

Based on available information, one of the Latah County collection sites is within the St. Joe National Forest; the other 6 collection sites appear to be on private lands. 
Heritage Rank: G3G4, ID: S1 MT: SNR

\section{Natural History}

\section{A. Taxonomy}

Order: Plecoptera

Family: Perlodidae

Cascadoperla trictura (Hoppe 1938)

Type locality: Maple Valley, Cedar River, King County, Washington.

The taxon was first described as Perla trictura, later associated with the genus Isoperla, and more recently associated with Cascadoperla. Cascadoperla is a monotypic genus (Szczytko and Stewart 1979).

\section{B. Species Description}

Adult Male Morphology: Body length is 8-9 mm. Macropterous, having forewing length $8-9.5 \mathrm{~mm}$. General body color is yellow to light brown. A round black spot covers the interocellar area of head and continues to the anterior margin of frons. Pronotum is light yellow with a median light stripe bordered by 2 longitudinal dark brown bands containing vermiform rugosities. Wings are hyaline with veins medium brown. Abdominal terga have 3 longitudinal dark brown stripes and 8 rows of longitudinal dots (Szczytko and Stewart 1979).

Mature Larval Morphology (reared larvae): Length of mature male is $9.1-10.3 \mathrm{~mm}$; length of mature female larva is $10.2-12.6 \mathrm{~mm}$. Interocellar area of head is medium brown, wide, with a dark brown pigment band extending across the frons; the anterior margin has a narrow light, transverse band and a row of small, stout spinulae on the occipital ridge. The pronotal margin is fringed with small, stout hairs and with numerous long hairs irregularly placed at the upper and lower angles and posterior margin. Pronotum has a medial light yellow stripe bordered by 2 wide, medium brown longitudinal bands; rugosities absent; light narrow band on the lateral and posterior margins (Szczytko and Stewart 1979).

Reproductive Biology: Based on material examined by Szczytko and Stewart (1979), emergence occurs from mid-May until July in creeks and rivers. Baumann, Gaufin, and Surdick (1977) report that adults emerge from April to July.

Ecology: Found in creeks and rivers (Baumann et al. 1977; Szczytko and Stewart 1979). Merritt and Cummins (1996) report the habit of this species as "clingers, crawlers and like most Perlodidae are probably predators, consuming other insects, especially midges and blackflies. 


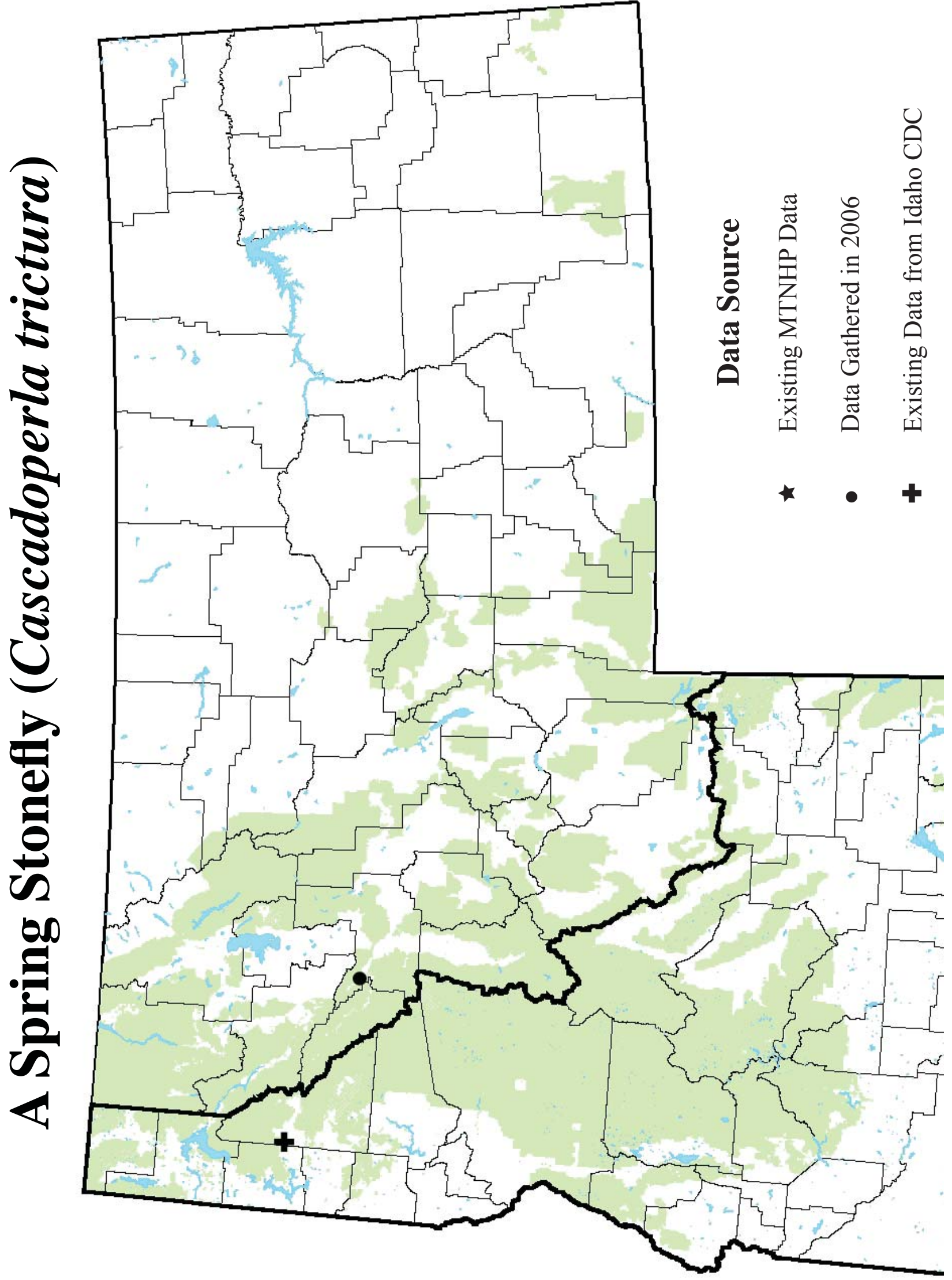

Appendix C - 12 


\section{Range and Known Sites}

The distribution includes British Columbia, Washington, Oregon, California, Idaho, and Montana (Szczytko and Stewart 1979). In Idaho, the species is known from one collection site: Coeur d'Alene River, Kingston, Shoshone County (Baumann personal communication 2005). In Montana, this species is known from one stream in 2 collections, Ninemile Creek, Missoula County (Stagliano, this study 2006).

\section{Species Abundance}

Baumann et al. (1977) describe this as a "rare species." On 11 April 1969, the single reported collection site yielded 41 male and 43 female specimens (Baumann personal communication 2005). The Montana larval collection site reports 5 specimens total for 2 samples.

\section{Current Status}

\section{A. Why Species is of Conservation Concern}

The species is known from a single collection in Idaho (Baumann personal communication 2005, Szczytko and Stewart 1979) and a single stream in Montana (Stagliano, this study 2006).

\section{B. Threats}

Specific threats to MT/ID populations of $C$. trictura have not been identified. In general, stonefly populations are affected by changes to aquatic habitat such as alteration of flow patterns, streambed substrate, thermal characteristics, and water quality. Alteration and degradation of aquatic habitat is the primary concern for Idaho populations.

\section{Distribution Relative to Land Allocations}

The Coeur d'Alene River corridor upstream and downstream from Kingston, Shoshone County, and the Ninemile Creek section in Missoula County flows through private land and with minor exceptions to the farthest upstream reaches their are few immediate management implications for the USFS. 
Heritage Rank: G3, ID: S2 MT: SNR

\section{Natural History}

\section{A. Taxonomy}

Family: Nemouridae

Malenka tina (Ricker1952)

Type Locality: Holotype male: Iron Creek, Lewis County, Washington (Ricker 1952).

Type Locality: Female: Rock Creek Ranger Station, Twin Falls County, Idaho (Jewett 1954).

The species was originally described as Nemoura (Malenka) tina (Ricker 1952).

\section{B. Species Description}

Adult Male Morphology: Body length is $5 \mathrm{~mm}$; total length to tip of wings is $6.5 \mathrm{~mm}$. Color is brown. Two pairs of branched gills occur on the neck ventrally. Wings have no pigmented markings. Abdominal segments are mostly membranous through the eighth segment, but dorsally they have more sclerotized anterior margins and a sclerotized plate occurs on either side of the median line ventrally. The ninth sternite has an elongate lobe from the anterior margin; the posterior margin is triangularly produced with a terminal knob slightly upturned. The subanal lobes are triangular and sclerotized near the outer margin, terminating in two strong hooks, one shorter and stouter than the other. The tenth tergite is sclerotized dorsally with a posterior sclerotized plate bearing the supra-anal process on its tip; the process is erect, bent forward at the tip and mostly sclerotized. The cerci are membranous, with rounded sclerotized knobs pointing inward at the base (Ricker 1952).

Adult Female Morphology: Body length is $7.5 \mathrm{~mm}$; total length to wing tips is $9 \mathrm{~mm}$. The female is similar to the male in general morphological details but is slightly larger in size. The $8^{\text {th }}$ sternite is completely bisected by a notch which is margined by heavy sclerotization in its narrow anterior third (Jewett 1954).

Reproductive Biology: No information is available.

Ecology: The larvae are found in small mountain streams (Newell and Minshall 1978). Baumann (personal communication 2005) reported that this species was collected in 1964 in seeps outside the main Big Wood River channel. Most of the Nemouridae species are shredders or collector-gatherers utilizing coarse plant materials (Merritt and Cummins 1996)

\section{Range and Known Sites}

Rangewide, Malenka tina reportedly occurs in Washington, Oregon, Montana, Idaho, Utah, and Nevada (NatureServe 2006). In Idaho, the species has been collected in Blaine, Butte, Idaho, Lemhi, Minidoka, and Twin Falls counties (Baumann et al. 1977; Newell and Minshall 1978). In 


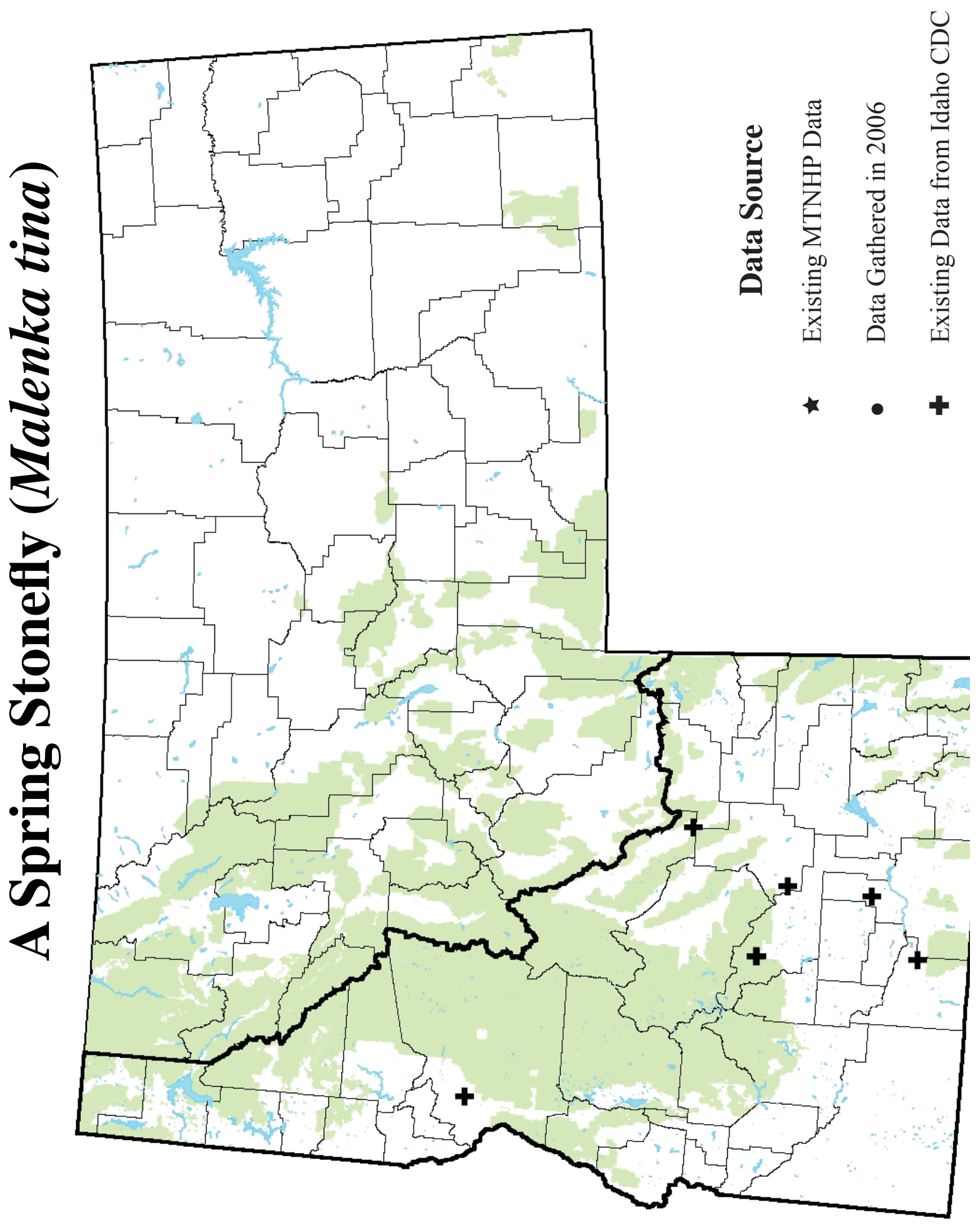

Appendix C - 15 
Montana, we have no specific site collection records, although a specimen has been reported to be from Missoula Co. (Baumann et al. 1977).

\section{Species Abundance}

On 17 February 1964, 2 male and 1 female specimens were collected on the Big Wood River near Ketchum (Baumann personal communication 2005).

\section{Current Status}

\section{A. Why Species is of Conservation Concern}

Malenka tina has no federal or state agency status at the present time. Based on available information, the species appears to have a broad "Coast, Cascade, and Rocky Mts." geographic distribution. It also has a broad north-south and east-west county distribution within Idaho. Baumann et al. (1977) report that Malenka tina is known from six Idaho counties but also observe that $M$. tina is "rather restricted in its distribution." In Idaho, the distribution of M. tina and its ecological needs require further study.

\section{B. Threats}

Specific threats to Idaho or MT populations of Malenka tina have not been identified. In general, stonefly populations are affected by changes to aquatic habitat such as alteration of flow patterns, streambed substrate, thermal characteristics, and water quality. Alteration and degradation of aquatic habitat is the primary concern for Idaho populations.

\section{Distribution Relative to Land Allocations}

With respect to the "Big Wood River, Hwy 93, near Ketchum" (Baumann personal communication 2005) collection site, it is impossible to know whether the collection was made on private land, BLM land, or National Forest land, as all three exist in the immediate area of Ketchum. The collection at Magic Mountain, Twin Falls County (Jewett 1954), was certainly made within a National Forest. Newell and Minshall (1979) indicate that Malenka tina has been collected at upper Birch Creek (Lemhi County) and Rock Creek (Twin Falls County); these collection sites have strong potential to be within private lands. If Montana populations exist in the southwest part of the state, they will most likely occur in the BLM managed lands or the Beaverhead-Deerlodge Forest along the Idaho border. 


\section{A. Taxonomy}

Order: Plecoptera

Family: Leuctridae

Megaleuctra kincaidi Frison, 1942
A Stonefly: Needleflies

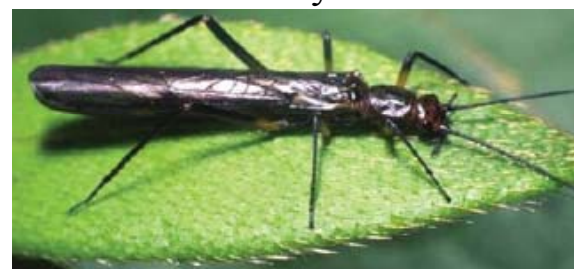

Photo of Megaluctra from Colorado (not kincaidi) taken by C. Riley used from The Tree of Life Web Project. http://tolweb.org/Leuctridae/13941

Type locality: Fryingpan Creek, Mt. Ranier, Washington.

\section{B. Species Description}

Adult Morphology: Body length is $13 \mathrm{~mm}$; length to tip of wings is $15 \mathrm{~mm}$. Head, thorax, abdomen, and appendages are light to dark brown. The head through the compound eyes is wider than the pronotum. The three ocelli form a nearly unilateral triangle. The pronotum is about as wide as long, margins are light colored, and a central area is darker and has an indication of a wide, longitudinal, lighter median stripe. The second tarsal segments are much shorter than the third. The middle of the ninth tergite has two sharply pointed tubercles. The tenth tergite has a peculiar, highly sclerotized structure arising between and above the anal cerci that is bent forward at about a right angle. Subanal process is long and recurved over the dorsal tip of the abdomen. Anal cerci are long and single segmented. Wing membranes are essentially hyaline, and veins are dark brown. The pterostigmatic space in both forewings and hindwings have a conspicuous marking: the area next to the subcosta is hyaline, which is followed by a dark patch and then a milkywhite patch. No gill remnants are on any body area (Frison 1942).

Mature Larval Morphology: Body length is $15 \mathrm{~mm}$. General color is light brown. Cercal segments are at least $17 \mathrm{~mm}$. Antennae over $40 \mathrm{~mm}$ (tips missing). Gills are absent. The body is elongate, the wing pads extending nearly parallel to the axis of the body. The body is covered with fine hairs in length equal to one-fifth the length of the middle abdominal segments. A ring of spines encircles the posterior end of the cercal segments. Coarse stiff hairs or bristles are on the legs, particularly on the outer surfaces; bristles are absent elsewhere. A pair of prominent spurs are visible at the inner distal end of all the tibiae. A continuous membranous fold is present along the sides of the first 7 abdominal segments. The tenth tergite is drawn out and contains a dorsal sclerotized structure. Subanal lobes are bulbous, not fused distally, and rather hidden between the tenth tergite and tenth sternite (Jewett 1954).

Reproductive Biology: No information is available.

Ecology: This species has been collected from April to July across its range (Baumann, Gaufin, and Surdick 1977). The two Idaho specimens were collected 30 June (Baumann personal communication 2005). Merritt and Cummins (1996) report that members of the genus Megaleuctra are found in springs and seeps. 


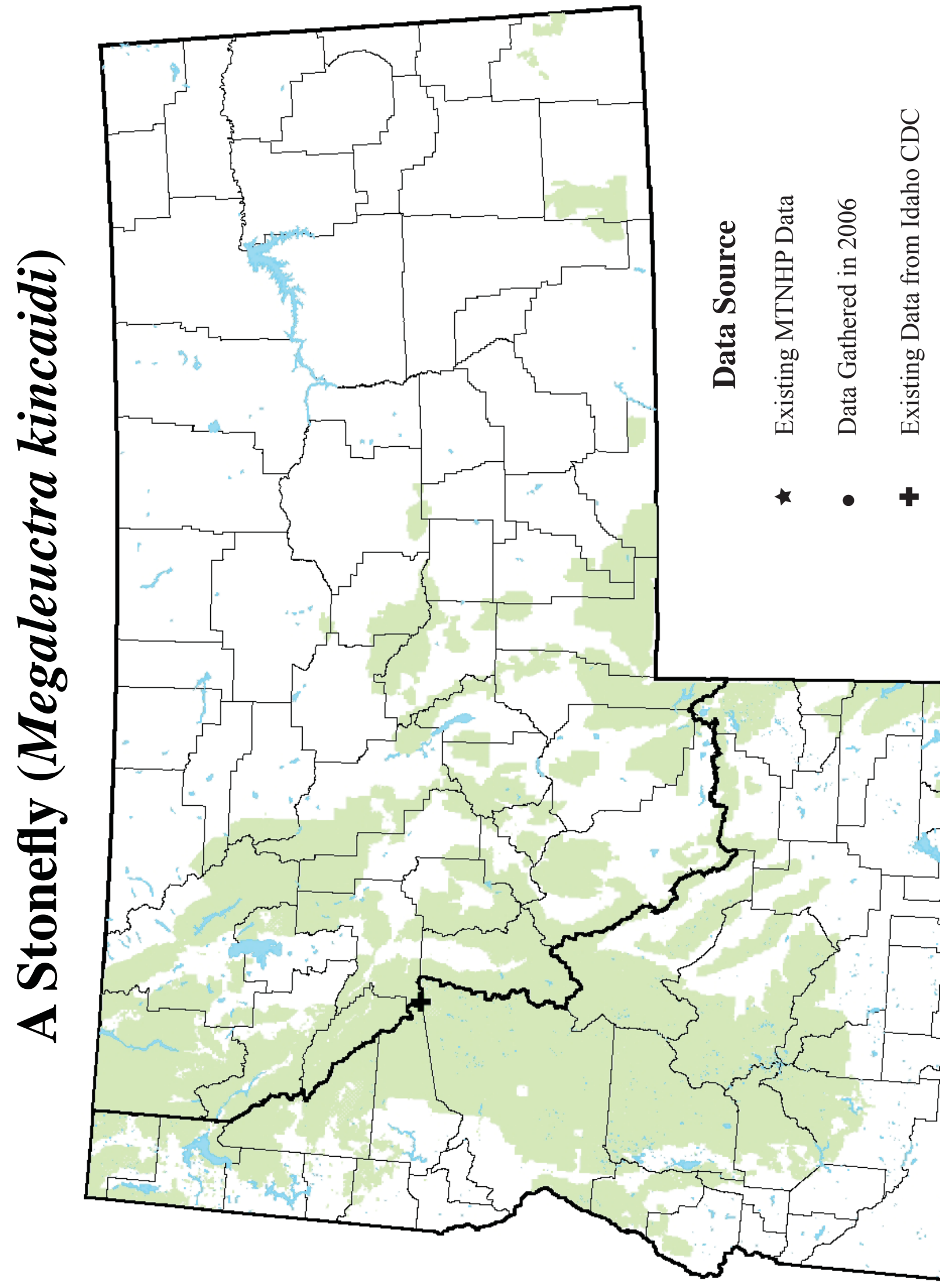

Appendix C - 18 


\section{Range and Known Sites}

Rangewide, the species occurs Idaho, Oregon, and Washington (NatureServe 2006). Only two Idaho collection sites have been reported: Latah County, Moscow Mountain (Jewett 1954) and "Clearwater County, Lolo Pass, Hwy 12" (Baumann, Gaufin, and Surdick 1977). Lolo Pass and Highway 12 occur in Idaho County, not far south of the Clearwater County line. The collector might have incorrectly recorded the county name or else the collection was made in Clearwater County away from Highway 12 in the general vicinity of Lolo Pass.

\section{Species Abundance}

Baumann, Gaufin, and Surdick (1977) describe this as a "rare species." One male and one female were collected at Lolo Pass (Baumann personal communication 2005). Only one mature larva was collected at Moscow Mountain (Jewett 1954).

\section{Current Status}

\section{A. Why Species is of Conservation Concern}

Baumann, Gaufin, and Surdick (1977) describe this as a "rare species. Only two collection sites are known in Idaho.

\section{B. Threats}

Specific threats to Idaho populations of Megaleuctra kinkaidi have not been identified.

In general, stonefly populations are affected by changes to aquatic habitat such as alteration of flow patterns, streambed substrate, thermal characteristics, and water quality. Alteration and degradation of aquatic habitat is the primary concern for Idaho populations.

\section{Distribution Relative to Land Allocations}

Idaho County, in the vicinity of Lolo Pass, is a checkerboard of one-square mile sections of privately-owned forest and National Forest. Moscow Mountain is a patchwork of mostly private lands with some state lands. This species could potentially occur in the Lolo Forest in Montana. 
Heritage Rank: G2, MT: SNR

Natural History

\section{A. Taxonomy}

Order: Plecoptera

Family: Leuctridae

Megaleuctra stigmata (Banks, 1900)

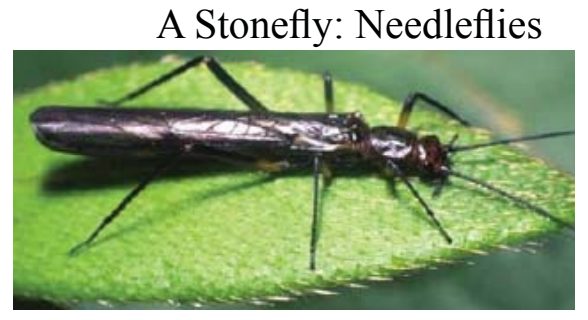

Photo of Megaluctra from Colorado (not stigmata) taken by C. Riley used from The Tree of Life Web Project. http://tolweb. org/Leuctridae/13941

Type Locality: British Columbia, Canada. Previously known as Neumora stigmata.

\section{B. Species Description}

Adult Morphology: Body length is $11-13 \mathrm{~mm}$; length to tip of wings is $15 \mathrm{~mm}$. Head, thorax, abdomen, and appendages are dark brown. The three ocelli form a nearly unilateral triangle. The pronotum is about as wide as long, margins are light colored, and a central area is darker and has an indication of a wide, longitudinal, lighter median stripe. No gill remnants are on any body area. For more detailed description see Frison (1942).

Nymph Morphology: Body length is $15 \mathrm{~mm}$. General color is light brown. Cercal segments are at least $17 \mathrm{~mm}$. A continuous membranous fold is present along the sides of the first 7 abdominal segments. The tenth tergite is drawn out and contains a dorsal sclerotized structure. Subanal lobes are bulbous, not fused distally, and rather hidden between the tenth tergite and tenth sternite (Jewett 1954).

Reproductive Biology: No information is available.

Ecology: Very little information exists about the ecology of this species (Baumann, Gaufin, and Surdick 1977). Merritt and Cummins (1996) report that members of the genus Megaleuctra are found in small springs and seeps, and are trophically shredder-detritivores.

\section{Range and Known Sites}

Rangewide, the species is known from Washington, British Columbia, Alberta, Idaho (Idaho \& Latah Co.), Montana (Lake \& Missoula Co.). It is known from <30 EO's (most in Canada), mostly springs, seeps and small rheocrenes (NatureServe 2006). No map is available!!

\section{Species Abundance}

Baumann, Gaufin, and Surdick (1977) describe this as a "rare species." No abundance or collection data is reported above the county distribution level. 


\section{Current Status}

\section{A. Why Species is of Conservation Concern}

Baumann, Gaufin, and Surdick (1977) describe this as a "rare species and it is reported to occur in only 2 counties in Montana.

\section{B. Threats}

Specific threats to MT populations of Megaleuctra stigmata have not been identified. In general, stonefly populations are affected by changes to aquatic habitat such as alteration of flow patterns, streambed substrate, thermal characteristics, and water quality. Alteration and degradation of aquatic habitat is the primary concern for MT populations.

\section{Distribution Relative to Land Allocations}

Without more specific site location, we cannot determine the extent that this species exists in USFS managed lands, therefore, we recommend dropping them from consideration of a SOI, since the small streams they inhabit are encompassed within the management plan by other well documented aquatic SOC. 
Heritage Rank: G3, ID: S1

\section{Natural History}

\section{A. Taxonomy}

Family: Leuctridae

Perlomyia collaris Banks, 1906

Type Locality: Wellington, British Columbia.

\section{B. Species Description}

Perlomyia collaris is based on a single female specimen. The following descriptions are taken from Frison (1936) who described two new species, $P$. solitaria and $P$. sobrina, solely on the basis of male specimens and female specimens, respectively, even while cautioning that each of his new species might later be synonymized with $P$. collaris. Perlomyia solitaria and $P$. sobrina have since been synonymized with P. collaris (Baumann, Gaufin, and Surdick 1977).

Male Morphology (as $P$. solitaria): Body length is $8 \mathrm{~mm}$. Wing length is $11 \mathrm{~mm}$. Body and appendages are dark brown. The membranous wings are uniformly infuscated with dark veins. The head is much wider than the pronotum; pronotum is much longer than broad with a slightly depressed medial longitudinal area or stripe. The lateral ocelli are about three times as far from one another as from the inner margin of the compound eyes. The median ocellus is far forward but less so than the distance between lateral ocelli. The maxillary palpi are very large. The first tarsal segment of the forelegs and middle legs is about as long as the third but in the hind legs much shorter; the second tarsal segment is very short in all legs. No gill remnants are evident. The first nine abdominal segments are unmodified and similar; the ninth segment has a small lobe at the base. The tenth segment is modified with cerci and with a small projection at the base, tapering to a sharp point. The sides of the tenth tergite have a small protuberance before the posterior margin (Frison 1936).

Female Morphology (as $\boldsymbol{P}$. sobrina): Head, thorax, legs, and wings are similar to the male of $P$. solitaria. The abdomen differs as follows: ventral sternites one to eight dark and heavily sclerotized; the eighth modified, mostly membranous and sometimes largely concealed by the seventh and ninth sternites; ninth sternite is heavily sclerotized; abdominal tergites one through eight are membranous except for a narrow longitudinal sclerotized stripe along the median line; ninth and tenth tergites are uniformly and darkly sclerotized as are most sternites (Frison 1936).

Larval Morphology (described from exuviae): Body length is about $12 \mathrm{~mm}$. Cerci have at least 23 segments. Antennae have about 100 segments. Gills are absent. Body is elongated. The wing pads are only very slightly angled from the axis of the body. The body is covered with extremely fine pile, appearing almost naked. The subanal lobes are fused mesally for about half their length, leaving a notch at the tip. Stout hairs (hardly bristles) appear on the legs and as a ring around each cercal segment (Jewett 1954). 


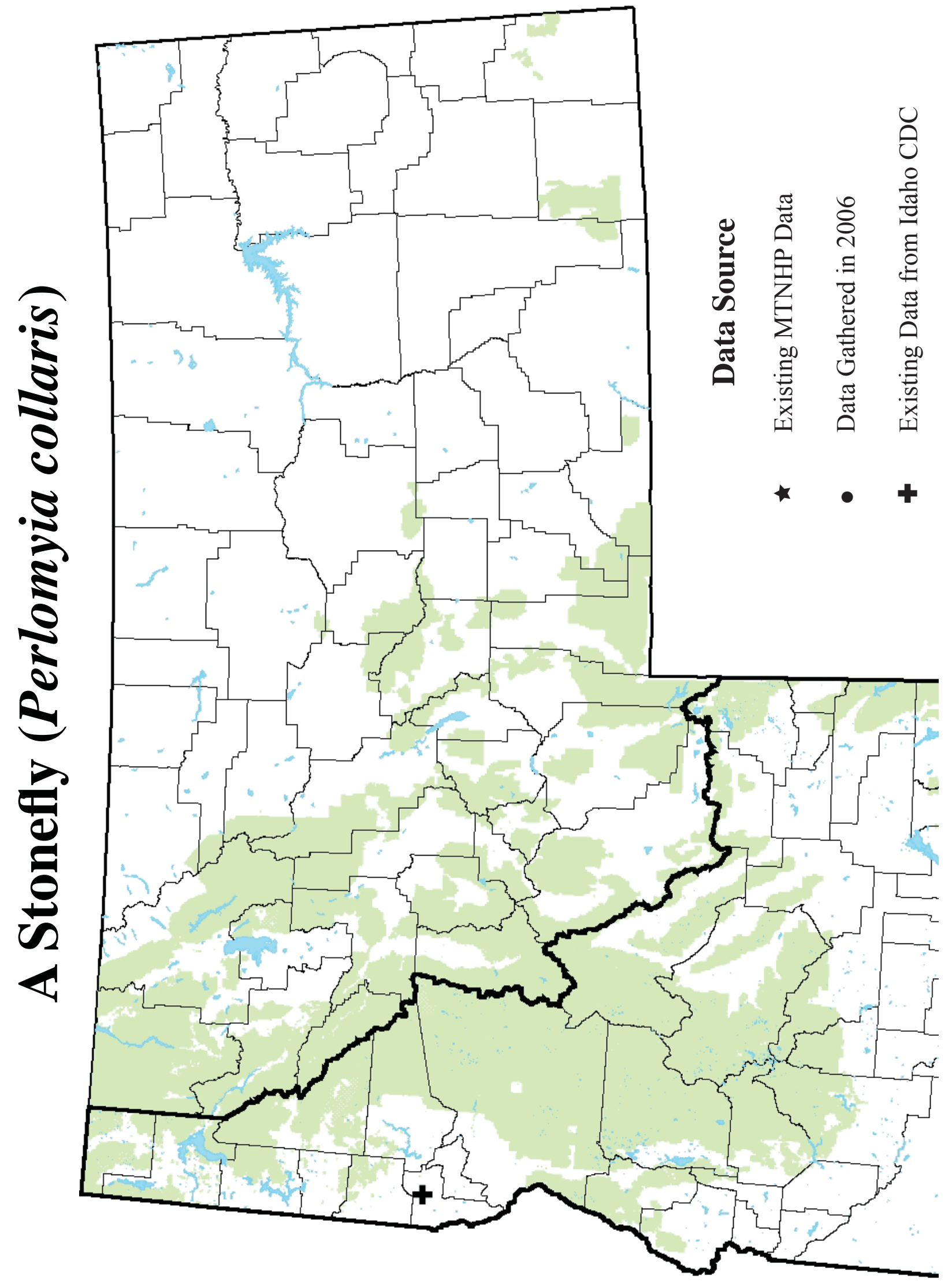

Appendix C - 23 
Reproductive Biology: Rangewide, the adults emerge from February to April (Baumann, Gaufin, and Surdick 1977).

Ecology: Perlomyia collaris occurs in creeks and rivers of the Pacific Northwest (Baumann, Gaufin, and Surdick 1977).

\section{Range and Known Sites}

Rangewide, Perlomyia collaris occurs in California, Oregon, Idaho, British Columbia, and the Yukon Territory (NatureServe 2006). In Idaho, the species is reported from one collection site, Cottonwood Creek, Nez Perce County, where adults were collected in an alfalfa field (Logan and Smith 1966).

\section{Species Abundance}

This species may be locally abundant; Baumann, Gaufin, and Surdick (1977) describe this species as occurring "commonly" in Northwest creeks and rivers. No information is available about the abundance of $P$. collaris in Idaho.

\section{Current Status}

\section{A. Why Species is of Conservation Concern}

Only one collection site has been reported for Idaho (Baumann, Gaufin, and Surdick 1977; Logan and Smith 1966).

\section{B. Threats}

Specific threats to Idaho populations of Perlomyia collaris have not been identified. In general, stonefly populations are affected by changes to aquatic habitat such as alteration of flow patterns, streambed substrate, thermal characteristics, and water quality. Alteration and degredation of aquatic habitat is the primary concern for Idaho populations.

\section{Distribution Relative to Land Allocations}

The entire length of Cottonwood Creek in Nez Perce County is within privately-owned lands, except for a very small $(<400 \mathrm{~m})$ area of land managed by the Bureau of Land Management. Therefore, this species may not be influential in USFS management plans. 


\section{A. Taxonomy}

Order: Ephemeroptera

Family: Ameletidae

Ameletus sparsatus McDunnough, 1931

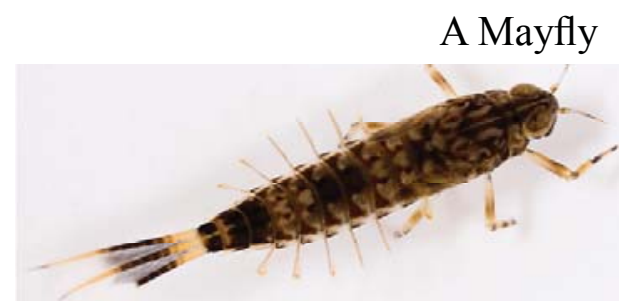

Generalized Ameletus larvae not sparsatus

McDunnough (1931) described this taxon based on imagos of both sexes. He described the larval form in 1934 (McDunnough 1934). Type locality: Blairmore, Alberta, Canada

\section{B. Species Description}

Adult Morphology: Body length: 10-12 mm. Eyes have green pigmentation in living males. Mesonotum is yellow with light brown at the periphery. Mesotergum is yellowish with brown longitudinal streaks (based on a preserved female imago specimen from Alberta, Canada). Fore wings transparent with some cross-veins surrounded with smoky brown, giving them a speckled appearance. Specimens from British Columbia, Alberta, and Colorado have well-defined dark patches on the fore wings (four larger patches in a preserved female imago from Alberta). Abdominal sternite 2 has a pair of C-shaped markings; ganglionic markings may be visible on sternites 7 and 8 (Zloty 1996, Zloty and Pritchard 1997). This species is likely to be confused with $A$. amador and A. falsus. The male genitalia resemble those of A. imbellis (Zloty 1996).

Larval Morphology: Body length: 10-11 mm. Antennae mostly brown with segments 2-4 pale. Labrum is pale with brown ovoid patch proximally. The dorsal surface of the front femora has numerous long spines and a fringe of sparse and relatively short hairs. The anterior surface of the front femora is yellow with a broad brown patch at the middle that does not extend onto the ventral surface. Posterolateral spines on abdominal segments 8-9 very long. Ganglionic markings sometimes visible on sternite 8 (Zloty and Pritchard 1997). Based on a large series of larvae from the Henrys Fork, eastern Idaho, younger larvae were pale and incompletely marked. All larvae, regardless of age, showed distinct subcutaneous ganglionic markings (Jensen 1966). Larvae of $A$. sparsatus could be confused only with larvae of $A$. cooki and A. suffusus.

Reproductive Biology: In Alberta, adults of this species emerge from mid-July to mid-August (Zloty and Pritchard 1997).

Ecology: This species is associated with larger, moderately flowing rivers and streams (Jensen 1966). Zloty and Pritchard (1997) found larvae in third- or fourth-order streams that had abundant littoral vegetation. The trophic relationships of larvae of Ameletus spp. include scrapers and collectors-gatherers (detritus, diatoms) (Merritt and Cummins 1996). 


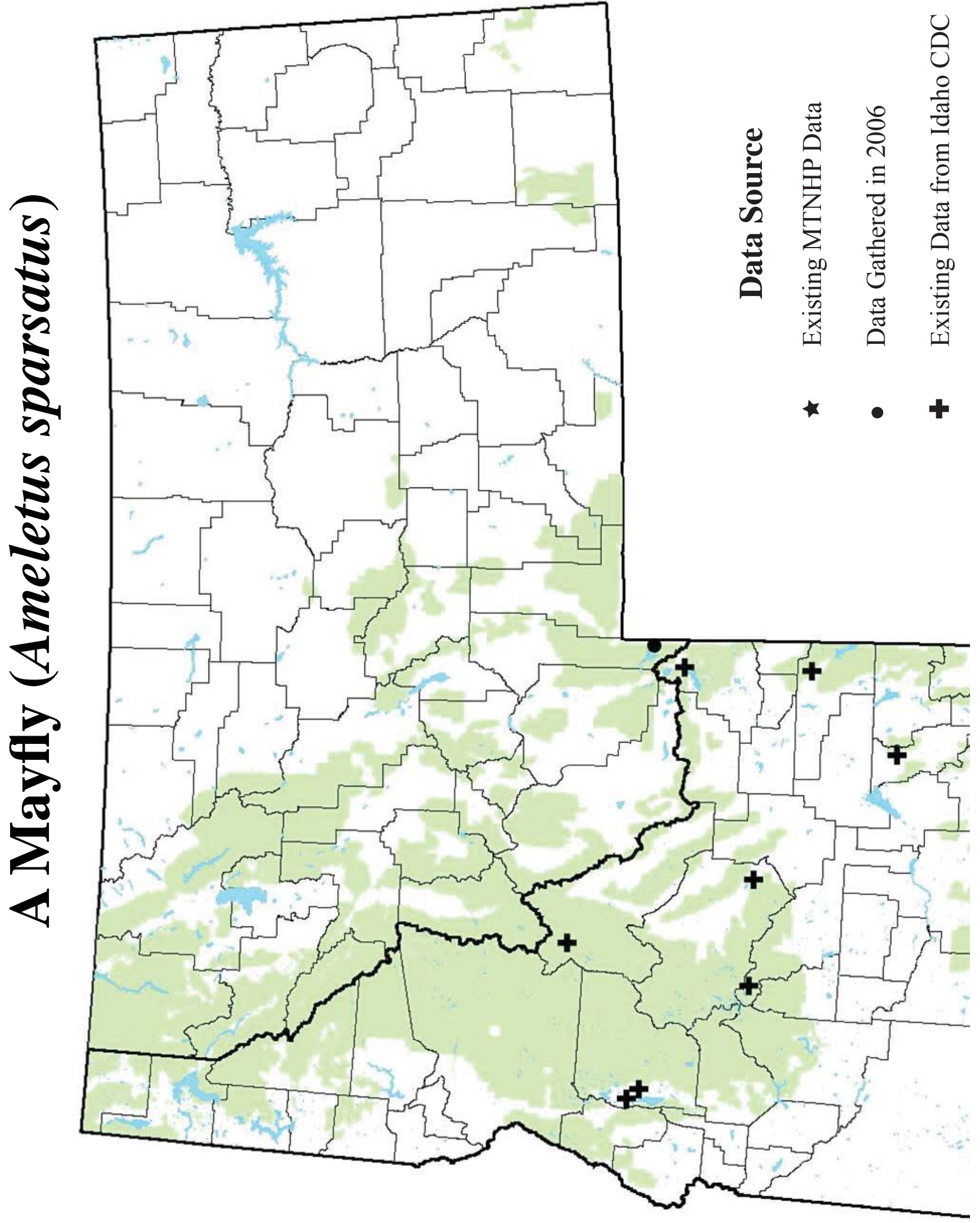

Appendix C - 26 


\section{Range and Known Sites}

Rangewide, Ameletus sparsatus is known to occur in Colorado, Montana, Idaho, Alberta, and British Columbia (NatureServe 2006).

In Idaho, Ameletus sparsatus has been reported from seven counties including Valley County in west-central Idaho; eastward to Blaine, Custer, and Lemhi counties; and southeasterly to Fremont, Bonneville, and Bannock counties (Jensen 1966, Newall and Minshall 1978). Jensen (1966) reported specimens from large and mid-sized rivers including the Henrys Fork, Salmon River, and Big Lost River; and from smaller drainages including Rapid Creek (Bannock County), Lake Fork Creek (Valley County), and Pine Creek (Bonneville County). A more recent publication by Zloty (1996) and the even more recent World Wide Web-based distribution map by Kondratieff (2000) agree that $A$. sparsatus is known from only two Idaho counties: Blaine and Valley.

In Montana, Ameletus sparsatus has been reported from the Madison River in Gallatin County adjacent to Yellowstone National Park. Unfortunately, the identification key to Ameletus species has not been used by bioassessment agencies, and thus we have very few species-level ID's. This species could potentially occur in mid-sized to larger river systems in the other counties in the southwestern part of Montana, but species-level records are just not available.

\section{Species Abundance}

Zloty and Pritchard (1997) reported that "mayflies of the genus Ameletus are common inhabitants of running waters in North America ...." and that "larvae are found in third or fourth order streams, where they are usually abundant in littoral vegetation." Jensen (1966) reported collecting "a large series" from the Henrys Fork in eastern Idaho. The only available, detailed information about the abundance of $A$. sparsatus in Idaho is associated with a locality sampled by the Idaho Department of Environmental Quality in 1994. Twenty-seven specimens were collected by one person during a single visit at one sampling station in Valley County.

\section{Current Status}

\section{A. Why Species is of Conservation Concern}

A. sparsatus is included in the Idaho Comprehensive Wildlife Conservation Strategy (2006) as a Species of Greatest Conservation Need because it is a "species lacking essential information pertaining to status." In Montana this species has stayed off the SOC list due to lack of reliable species records or information; further investigation is required. The Idaho distribution remains in question inasmuch as recent documentation (Zloty 1996, Kondratieff 2000) reports this species from only two Idaho counties whereas earlier research by Jensen (1966) recorded specimens from seven Idaho counties. The reason for the discrepancy is unknown, and the distribution recorded by Jensen (1966) apparently cannot be verified without revisiting the locations reported in his thesis.

\section{B. Threats}

Specific threats to Idaho and Montana populations of $A$. sparsatus have not been identified. In general, mayfly populations are affected by changes to aquatic habitat, such as alteration of flow patterns, streambed substrate, thermal characteristics, and water quality. 


\section{Distribution Relative to Land Allocations}

The majority of records in Idaho are in the southern half of the state. The northern extent of the documented Idaho range is at the southern edge of the Nez Perce National Forest. Specimens collected in Valley County in 1994 by the Idaho Department of Environmental Quality (personal communication 2005) were obtained at a stream sampling station within privately-owned land approximately 3 miles downstream from the boundary of the Boise National Forest. Most of that particular drainage flows through the Boise National Forest and is roaded, allowing for future surveys on the National Forest. Jensen's (1966) Blaine County collection site is likely on the Sawtooth National Forest.

The one collection in MT was made within the Gallatin National Forest adjacent to Yellowstone National Park, thus additional records could be expected within the park or in similar habitat in other sections of the Madison River. 


\section{Natural History}

\section{A. Taxonomy}

Family: Ameletidae

Ameletus suffusus McDunnough, 1936

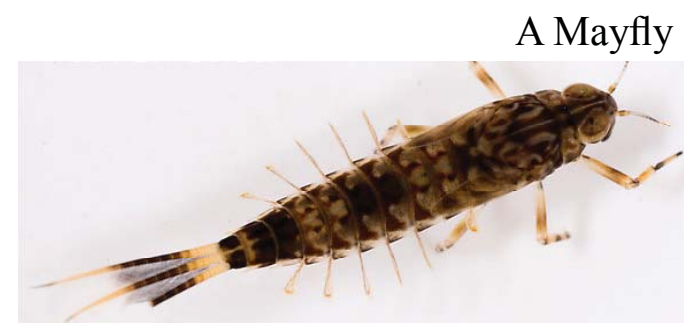

Generalized Ameletus larvae not suffusus

McDunnough (1936) described this taxon on the basis of a male holotype. In the same publication, he described the larval form.

\section{B. Species Description}

Adult morphology: Body length: 9-10 mm. Eyes have green pigmentation in living males. Mesonotum, in males, is yellow with brown shading at the lateral and posterolateral areas; scutellum yellow brown. Wings in both sexes suffused with brown, though the wing suffusion can be reduced or even absent in some individuals, making identification difficult. Ganglionic markings on abdominal sternite 8 in the male holotype and on sternites 7 and 8 in the female (Zloty 1996, Zloty and Pritchard 1997).

Wing suffusion in females is similar only to A. validus (Zloty and Pritchard 1997).

The male genitalia resemble those of A. andersoni, A. dissitus, A. exquisitus, A. vancouverensis, and A. vernalis (Zloty 1996).

Larval morphology: Body length: 9-10 mm. Antennae pale with a few middle segments brown. Labrum is pale with brown triangular patch proximally. The dorsal surface of the front femora with a few long spines and a fringe hairs of variable length. The anterior surface of the

front femora is pale with a narrow brown patch at the middle. Posterolateral spines on abdominal segments 8-9 relatively small. Ganglionic markings sometimes visible on sternite 8 (Zloty and Pritchard 1997).

Larvae of A. sparsatus could be confused only with larvae of A. cooki and A. sparsatus. Larvae are usually found in third or fourth order streams (Zloty and Pritchard 1997).

Reproductive Biology: In Alberta, adults of this species emerge from the first of July to early August (Zloty and Pritchard 1997).

Ecology: The trophic relationships of larvae of Ameletus spp. include scrapers and collectorsgatherers (detritus, diatoms) (Merritt and Cummins 1996).

\section{Range and Known Sites}

Rangewide, A. suffusus is known to occur Alberta, British Columbia, Oregon, and Idaho (Lester, McCafferty, and Edmondson 2002; NatureServe 2006). 


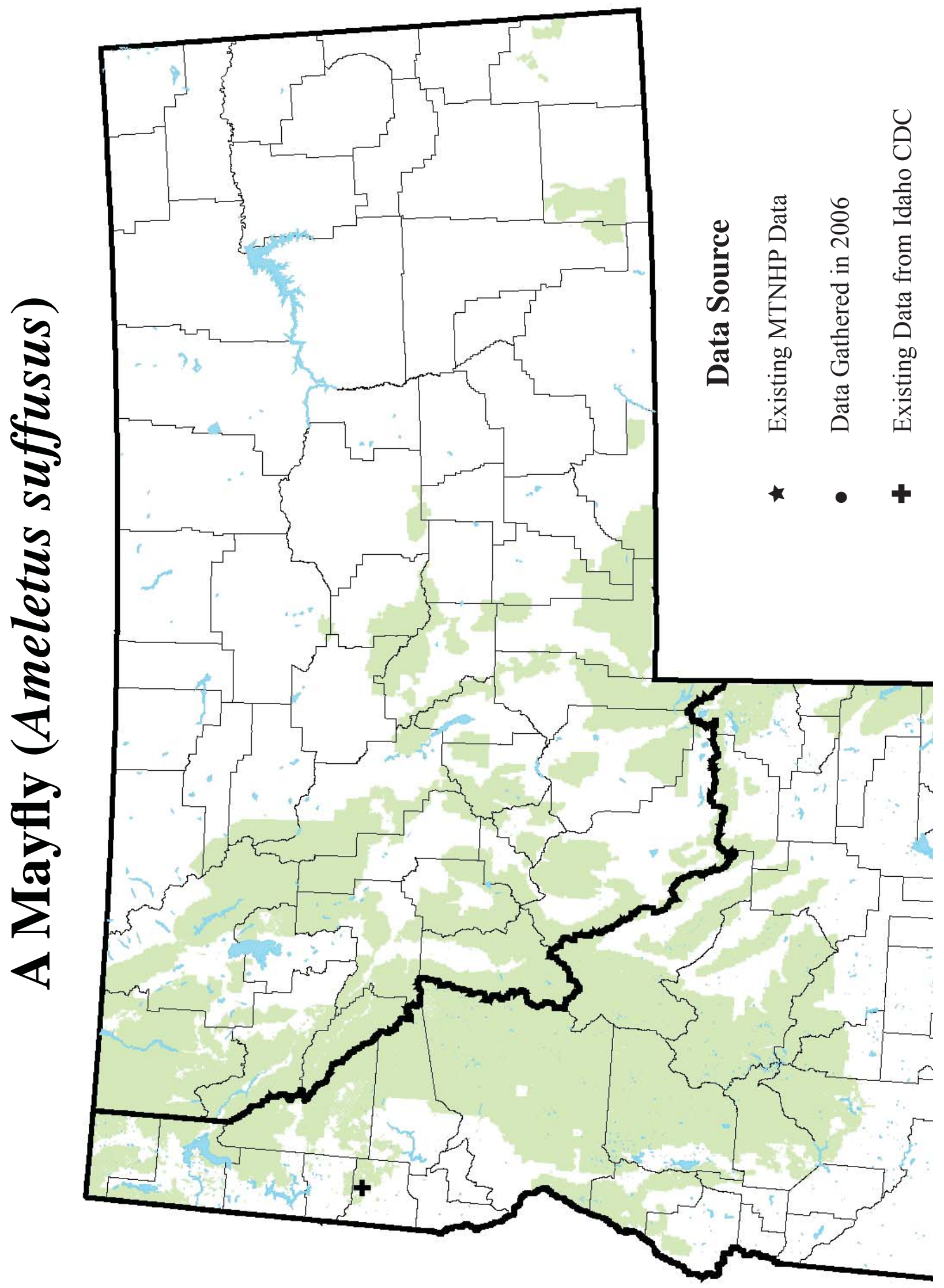

Appendix C - 30 
In Idaho, A. suffusus is known from a single larval specimen collected in Latah County (Lester, McCafferty and Edmondson 2002). The Idaho Department of Environmental Quality documented A. sparsatus in a stream in Valley County in 1994 - a stream different from the one Jensen (1966) reported — while conducting invertebrate sampling associated with DEQ's Beneficial Use Reconnaissance Program.

\section{Species Abundance}

Zloty and Pritchard (1997) reported that "mayflies of the genus Ameletus are common inhabitants of running waters in North America ...."

Jensen (1966) reported collecting "a large series" from the Henrys Fork in eastern Idaho.

The only available, detailed information about the abundance of $A$. sparsatus in Idaho is associated with a locality sampled by the Idaho Department of Environmental Quality in 1994. Twenty-seven specimens were collected by one person during a single visit at one sampling station in Valley County.

\section{Current Status}

\section{A. Why Species is of Conservation Concern}

This species is known from a single location and based on the collection of a single larva.

Beginning in 1993, the Idaho Department of Environmental Quality (DEQ) began collecting aquatic invertebrates at sampling stations on Idaho streams. At the end of the 2003 BURP season, a total of 5,182 stream sites had been sampled in Idaho (Idaho Department of Environmental Quality 2007). In 2005, the Idaho Conservation Data Center received comprehensive, statewide collection data from DEQ, and the data showed that, despite the number of stream sites sampled over about 12 years, DEQ had not discovered additional specimens of this species.

Ameletus suffusus has no federal or state agency status at the present time. This insect is very poorly known in Idaho.

\section{B. Threats}

Specific threats to Idaho populations of $A$. suffusus have not been identified. Strychnine Creek, Latah County, is the only location where this species has been collected. Nearly the length of the stream is roaded. In general, mayfly populations are affected by changes to aquatic habitat, such as alteration of flow patterns, streambed substrate, thermal characteristics, and water quality. Alteration and degradation of aquatic habitat is the primary concern for Idaho populations.

\section{Distribution Relative to Land Allocations}

Strychnine Creek, Latah County, is the only Idaho stream from which a specimen has been collected (Lester, McCafferty, and Edmondson 2002). Strychnine Creek is approximately 7-8 miles in length. Three-to-four miles of the headwaters, approximately half of the length of the stream, 
are on the Clearwater National Forest. The lower half of the stream meanders through private private, except for one isolated sliver of national forest which incorporates about 0.25 mile of the stream. 


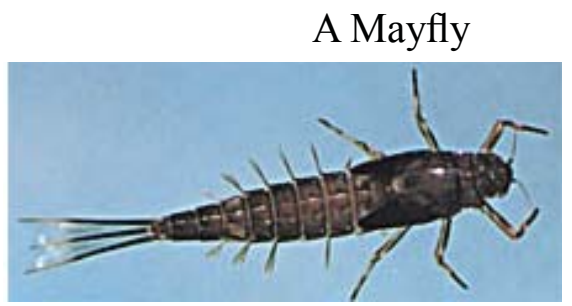

Generalized Ameletus larvae not tolae

\section{A. Taxonomy}

Order: Ephemeroptera

Family: Ameletidae

Ameletus tolae Zloty, 1996

Type Locality: Lick Creek, 6 mi. E. of Medical Springs, Oregon.

\section{B. Species Description}

Adult Morphology: Male imago body length is $6.5-8 \mathrm{~mm}$. Forewings are 6-7 $\mathrm{mm}$. Head is generally brown with dark brown ocellar tubercles; ocelli are opaque white; upper two-thirds of the compound eyes are gray, and the lower portion is dark brown. Forelegs are brown; middle and hind legs are amber to yellow. Wings are transparent; forewings have a milky suffusion in the stigmatic area; longitudinal veins are amber, and cross-veins are white and faintly visible. Abdominal sternite 1 is brown; sternites 3-8 are opaque white with dark brown ganglionic markings; sternite 9 is pale with extensive brown at anterior and lateral margins. Caudal filaments are golden brown (Zloty 1996). This species is similar to A. celer but is smaller and differs in details of genitalia (Zloty 1996).

Reproductive Biology: Imagoes and subimagoes have been collected 25 July - 8 August (Zloty 1996).

Ecology: The trophic functional classes of Ameletus larvae include scrapers and collectors-gatherers (detritus, diatoms) (Merritt and Cummins 1996).

\section{Range and Known Sites}

This species is known from a narrow geographic range including northeastern Oregon (Union County) and a single location (probably Benewah County) in the southern Idaho panhandle. The Idaho distribution is defined by a single specimen from "National Forest near St. Maries" (Zloty 1996).

\section{Species Abundance}

No information is available on the abundance in Idaho. 


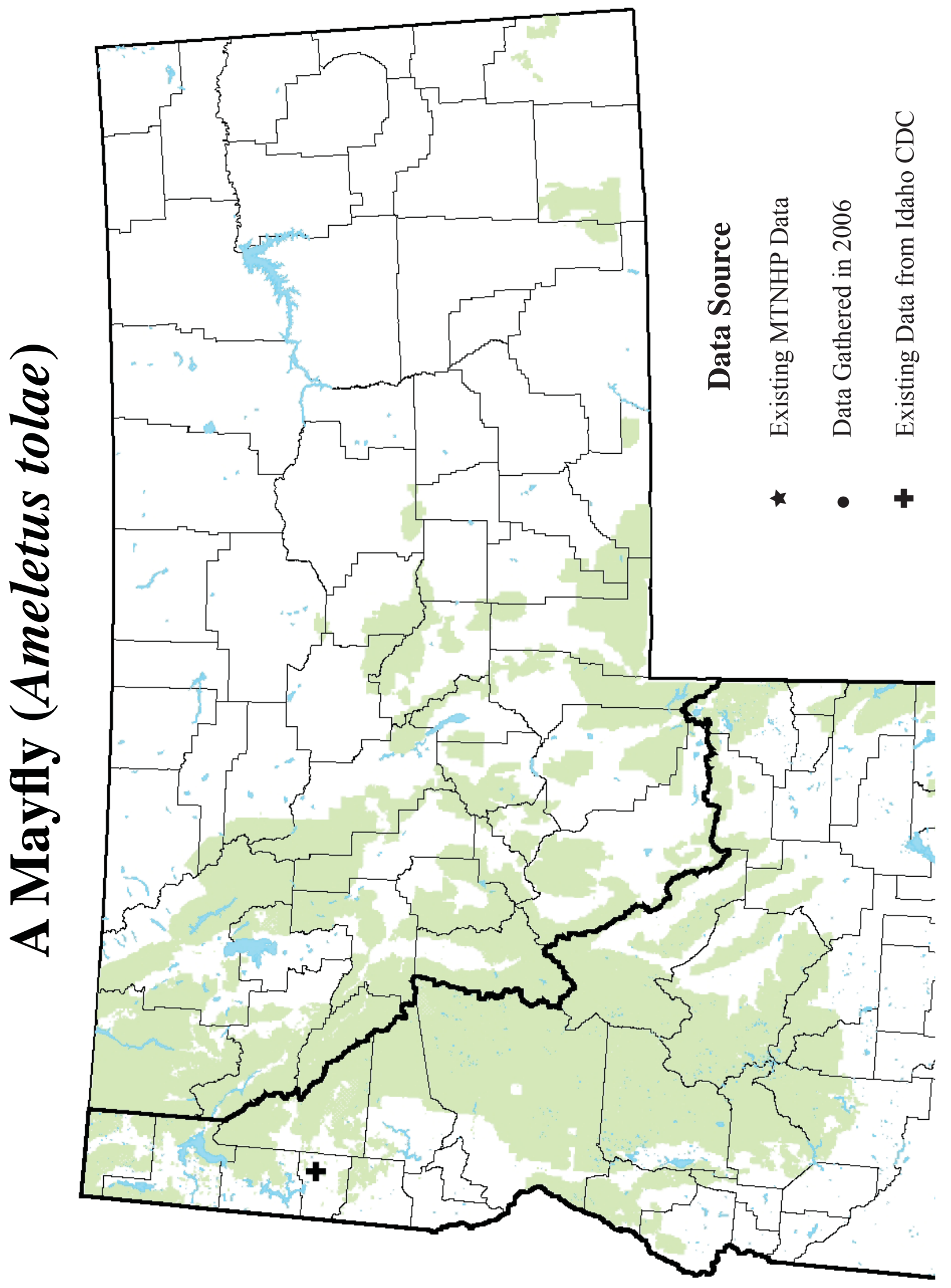

Appendix C - 34 


\section{Current Status}

\section{A. Why Species is of Conservation Concern}

In Idaho, this insect is known from one vaguely-described collection site, and it has a narrow rangewide distribution (Zloty 1996). The species is listed as a Species of Greatest Conservation Need in the Idaho Comprehensive Wildlife Conservation Strategy (2006) on the basis of restricted distribution and because it is a "species lacking essential information pertaining to status."

\section{B. Threats}

Specific threats to Idaho populations have not been identified. In general, mayfly populations are affected by changes to aquatic habitat, such as alteration of flow patterns, streambed substrate, thermal characteristics, and water quality. Alteration and degradation of aquatic habitat is the primary concern for Idaho populations.

\section{Distribution Relative to Land Allocations}

The nearest National Forest land is approximately $10 \mathrm{~km}$ from St. Maries, and most adjacent forest lands are highly fragmented into small parcels for a distance of 10-20 km from St. Maries. 
Heritage Rank: GH, SH

\section{Natural History}

\section{A. Taxonomy}

Order: Ephemeroptera

Family: Paraleptophlebiidae

Paraleptophlebia traverae McCafferty \& Kondratieff, 1999

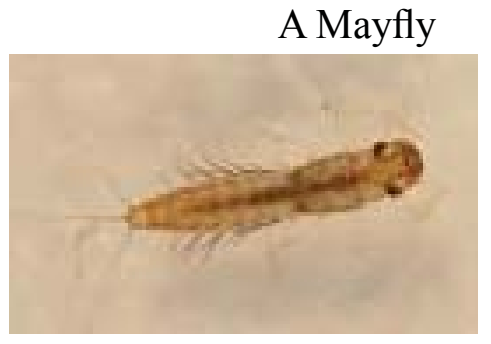

Photo of Paraleoptophlebia sp. larva, courtesy of Tom Murray

Type Locality: Grangeville, Idaho.

The original description is based on a single holotype male specimen collected in 1907 originally assigned to P. ruvifenosa (Traver 1935). The genitalia are preserved in balsam. One set of wings is dry mounted on two slides. The body, preserved in alcohol, is deteriorated and fragmented. The female morphology is unknown (McCafferty and Kondratieff 1999).

\section{B. Species Description}

Adult Male Morphology: Traver (1935) describes this as a brownish species without distinct color pattern. The head and thorax and tip of the abdomen are dark brown. The middle abdominal segments, legs, and tails are paler brown. The wings have reddish longitudinal veins with cross-veins also tinged except in the basal $3^{\text {rd }}$. The stigmatic region is heavily tinged. The $9^{\text {th }}$ sternite is narrowly divided by a V-shaped notch. In seeming contrast, McCafferty and Kondratieff (1999) state that the wings of this specimen are completely hyaline with no staining.

Reproductive Biology: No information is available.

Ecology: The trophic functional groups of Paraleptophlebia larvae include collectors-gatherers (coarse detritus, diatoms) and facultative shredders-detritivores (Merritt and Cummins 1996).

\section{Range and Known Sites}

This species is known from a single specimen collected at Grangeville, Idaho (Jensen 1966, McCafferty and Kondratieff 1999, Traver 1935).

\section{Species Abundance}

No information is available on the abundance in Idaho. 


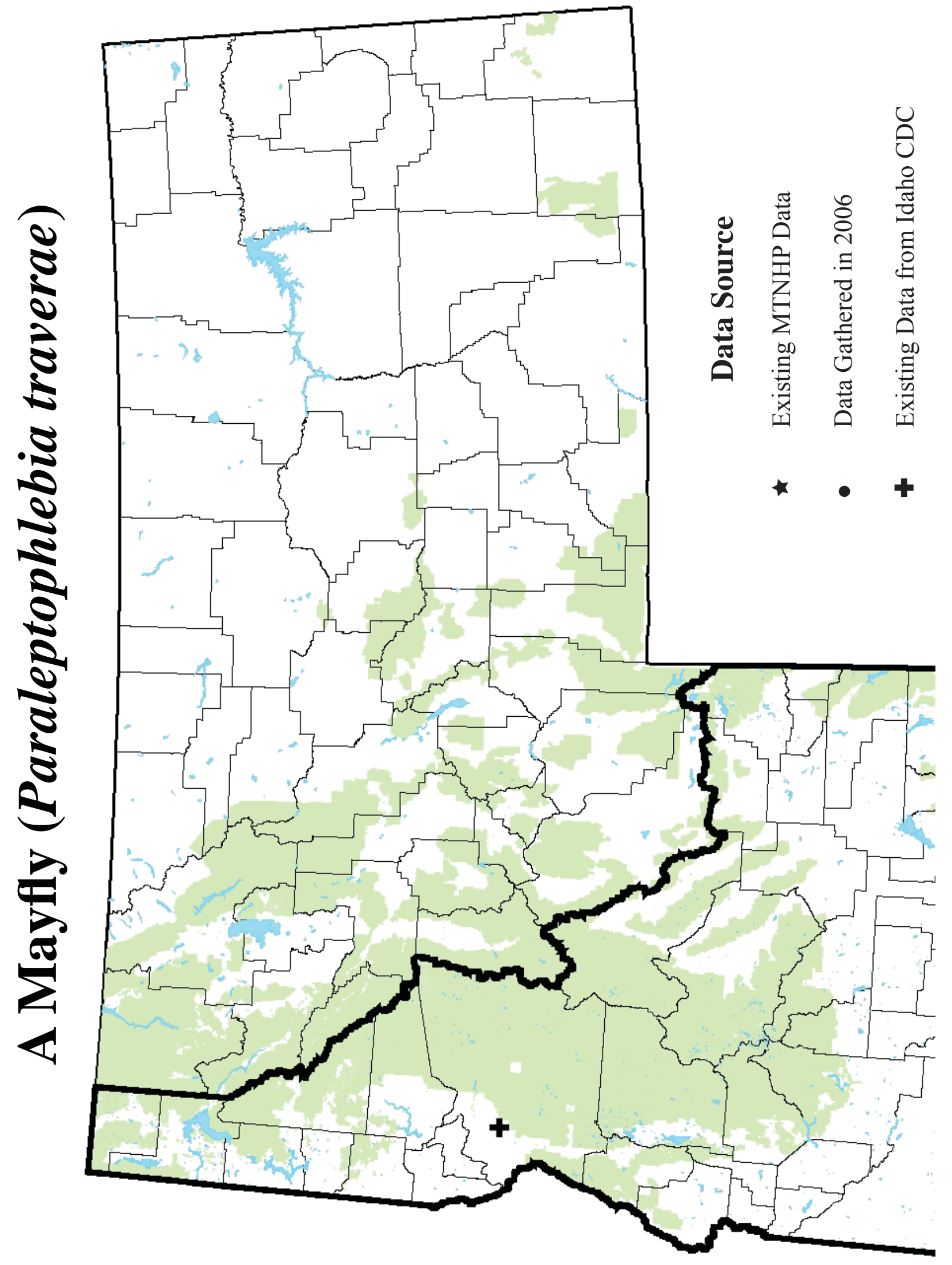

Appendix C - 37 


\section{Current Status}

\section{A. Why Species is of Conservation Concern}

NatureServe (2006) states that "this species is poorly known. It may be a restricted and rare species, but in essence the actual species involved has not been recorded in the past 67 years under any name." The species is known only from a single specimen (McCafferty and Kondratieff 1999) and may be possibly extirpated. The Idaho Department of Environmental Quality (2007) has conducted annual stream sampling for aquatic invertebrates since 1993. During the years 1993-2005, no individuals were found (Idaho Department of Environmental Quality personal communication 2005).

\section{B. Threats}

Specific threats to Idaho populations cannot be identified without information on its current status which may be possibly extirpated. In general, mayfly populations are affected by changes to aquatic habitat, such as alteration of flow patterns, streambed substrate, thermal characteristics, and water quality. Alteration and degradation of aquatic habitat is the primary concern for Idaho populations.

\section{Distribution Relative to Land Allocations}

The only reported location, "Grangeville," is too vague to identify land allocation. All lands immediately surrounding Grangeville are privately-owned. At a distance of 4-5 km south and east of Grangeville, small, scattered parcels of State-owned lands and lands managed by the Bureau of Land Management occur. National Forest lands lie east of Grangeville at a distance of approximately $6 \mathrm{~km}$. 


\section{A. Taxonomy}

Class: Gastropoda

Family: Lymnaeidae

Stagnicola elrodi (Baker and Henderson, 1933)

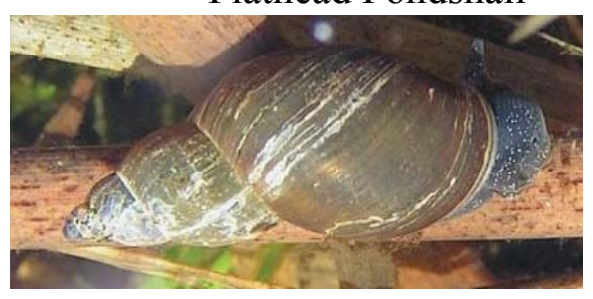

Generalized Stagnicola not elrodi

\section{Type Locality: Flathead Lake, Lake Co., MT}

Despite the recognition of this taxon as a distinct species, some authorities have raised uncertainty regarding its identity and validity. R. Dillon (Northwest Biological Assessment Workgroup Gastropod Workshop, 2006) has suggested that multiple existing taxa (elrodi and elrodiana) are synonyms of the pondsnail ("Stagnicola" emarginata), which he places in the genus Lymnaea along with all other nominal members of the genus Stagnicola. Regarding elrodi and elrodiana - Hubendick (1951) considered both nomina to be synonyms of Lymnaea emarginata. Burch (1989) puts elrodi in the emarginata group and elrodiana in the elodes group. The range in variation in shell morphology of species of Stagnicola is tremendous, and basing different species on this character will lead to problems (Dillon pers comm. 2006), although he has not specifically published accounts synonomizing these species. "In any case, it's hard to find evidence in any of this that populations of either elrodi or elrodiana comprise valid biological species."

\section{B. Species Description}

The shell of this aquatic snail is dextrally spiraled and conical in general shape. The columella is lightly twisted, and the shell is light brown; body is dark (see photo) (Frest 1999).

Reproductive Biology: This species is hermaphroditic. No information is available regarding the timing of reproduction or other aspects of reproductive ecology.

Ecology: This species occurs in vegetated bays of Flathead Lake. Aquatic vegetation and algae are generally abundant at occupied sites. Most Lymnaeidae snails are scrapers of algae and other plant materials.

\section{Range and Known Sites}

Rangewide, Stagnicola elrodi is known to occur in Montana (NatureServe 2006). In Montana, old records exist for multiple sites within the Flathead Lake basin (See distribution map). Originally probably restricted to Flathead Lake and a few larger lakes and slow-flow riverine situations in the upper Flathead River valley, Lake and Flathead Counties and Flathead Indian Reservation, MT. Current distribution is uncertain; 1 site was collected in upper Flathead River valley in 1991, but in several of the old sites, no live specimens were found (Frest and Johannes 1995). Confirmed to survive in Flathead Lake in 1994 (T. Frest pers. comm. 2000). No new site records have been added in recent years, since the Frest and Johannes (1995) revisit surveys. 


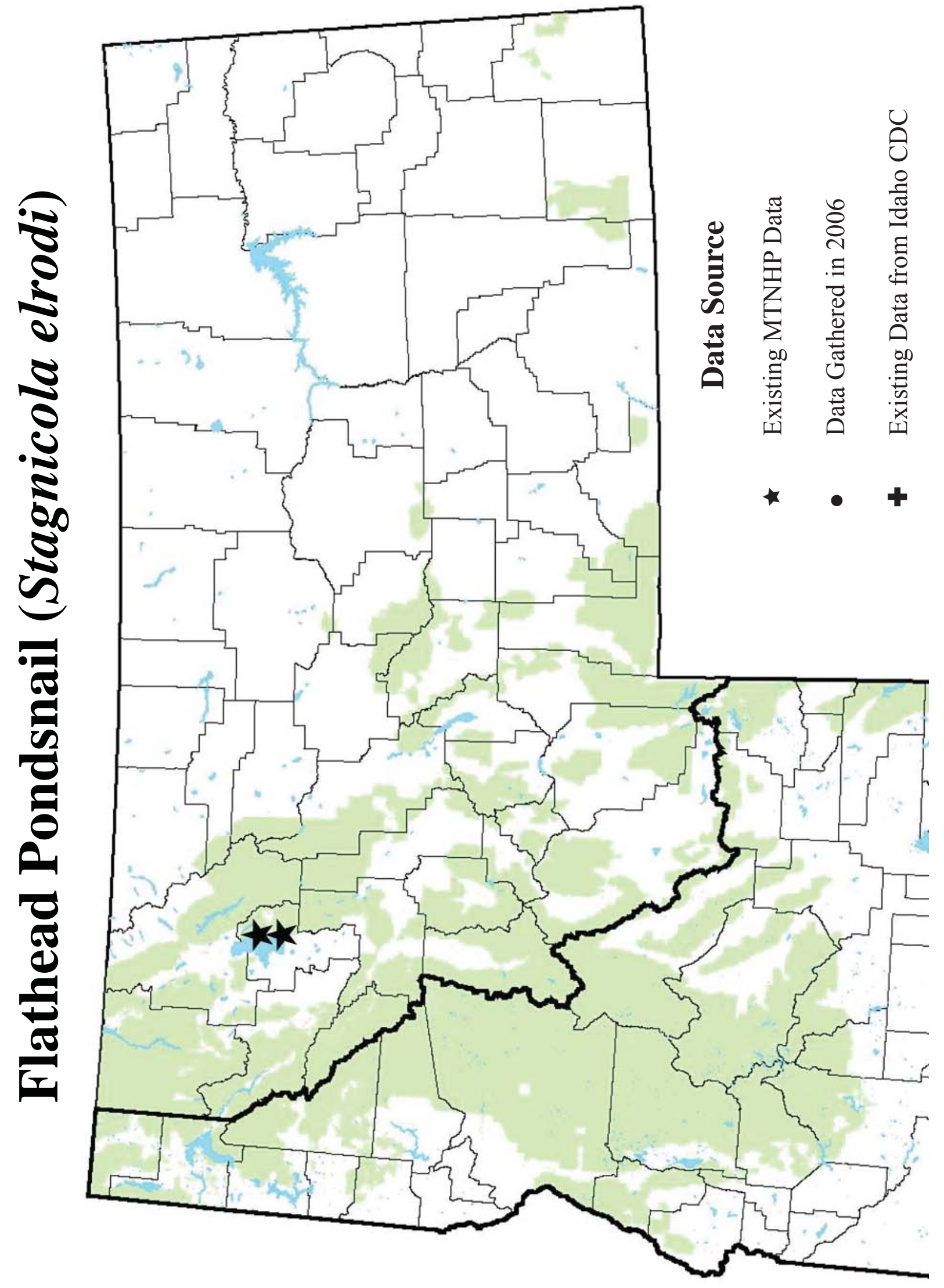

Appendix C - 40 


\section{Species Abundance}

Global Abundance: 1 - 2500 individuals. The species is believed to be declining from previously reported sites. Data do not indicate whether the decline was historical or is ongoing, and current population status is not accurately known.

\section{Current Status}

\section{A. Why Species is of Conservation Concern}

This "species" is limited in distribution to shallow bays of Flathead Lake, MT. It has only been found in this one lake, despite extensive searches elsewhere by R. Brunson. Populations seem to be declining due to current and ongoing threats; loss of some historic sites has occurred (Frest and Johannes 1995). Water pollution is beginning to be a significant in this area (T. Frest pers. comm. 2000).

\section{B. Threats}

Water pollution and accumulation of fine sediments has been labeled to be a significant threat to the populations in this area; ultimate sources of these are increasing shoreline development and agriculture, including grazing, that is causing eutropification.

\section{Distribution Relative to Land Allocations}

Known locations within the bays of Flathead Lake border the Mission Mountain Tribal Wilderness Area which is managed by the CKST. Thus, there is no immediate USFS Region 1 managed lands that would affect these populations, but significant portions of watersheds of tributaries to Flathead Lake can fall under USFS management. 


\section{Natural History}

\section{A. Taxonomy}

Class: Gastropoda

Family: Acroloxidae

Acroloxus coloradensis (Henderson 1930)

Type locality: Peterson Lake, 3.4 mi. WSW of Nederland, Boulder
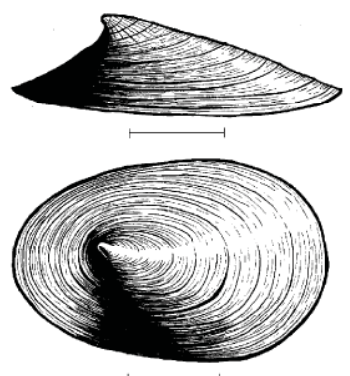

Drawing of the shell of Acroloxus coloradensis used with permission from Clarke Co., Colorado; types not examined. This species is the only representa(1981). tive of the family Acroloxidae in North America.

\section{B. Species Description}

See Clarke (1981) for a good description and illustration. In general limpets have a single coneshaped shell and a suction foot with well developed eyes and tentacles (see drawing).

Reproductive Biology: The breeding biology of Acroloxus coloradensis is not well understood.

Ecology: Habitat is high-altitude lakes and ponds. In Colorado, it is typically found at elevations between 2675 and $3025 \mathrm{~m}$ and glacial deposits along at least part of shorelines. In Montana it has been reported in high mountain lake (Lost Lake) within a small drainage basin $(<250 \mathrm{ha})$, on cobble-gravel substrate. It is an extreme environmental specialist to small alpine lakes only. Macrophytes are generally rare; and the species appears to be a stenothermal lithophile (Paul and Clifford 1991). Its trophic status is primarily a grazer and secondarily a scraper of algae or diatoms (Clarke 1981).

\section{Range and Known Sites}

Rangewide, Acroloxus coloradensis is known to survive in Alberta and British Columbia, $\mathrm{CO}$ and MT; some of the other sites need rechecking. The MT site Lost Lake is within Glacier National Park, and very near the Columbia drainage. Lake Iris and an unnamed lake north of Geikie Station, Beaver River in Jasper National Park, Alberta. No map available for this species.

\section{Species Abundance}

Very few, extremely small, isolated populations makes this species rare rather than uncommon. 


\section{Current Status}

\section{A. Why Species is of Conservation Concern}

Acroloxus coloradensis is only known from a very few, extremely small, isolated populations coupled with confined alpine lentic habitat make dispersal of this species unlikely. It is an extreme environmental specialist in small alpine lakes only. It has no USFWS status at the present time, although it is currently a US Forest Service Species of Concern (SOI) G3 and listed $\mathrm{S} 1$ in Montana. These rankings were largely due to the lack of localities that this species has been reported. Enough survey work has probably been done in CO and MT to demonstrate that this is a rarespecies, with declining numbers and, likely, populations.

\section{B. Threats}

Specific threats to populations are habitat loss and degredation coupled with a lack of dispersal mechanisms to colonize other lakes. High recreational usage of lakes may have an impact.

\section{Distribution Relative to Land Allocations}

In Montana, Acroloxus coloradensis is unlikely to occur outside of Glacier National Park (Glacier and Flathead Counties) which is managed by the National Park Service, and thus, has little management implications at the Northern Region 1 Forest Service level, unless it is discovered in the high elevation lakes of the Bob Marshall or high elevation portion of the Flathead National Forest. 